\title{
INTIMACY-GEOPOLITICS OF REDD+ EXPLORING ACCESS \& EXCLUSION IN THE FORESTS OF SUNGAI LAMANDAU, INDONESIA
}

BY

PETER JAMES HOWSON

A thesis submitted to the Victoria University of Wellington in fulfilment of the requirements for the degree of Doctor of Philosophy

Victoria University of Wellington

2016 

To be truly radical is to make hope possible, rather than despair convincing.

- Raymond Williams, Sources of Hope, 1989 



\section{ABSTRACT}

Indonesia remains the largest contributor of greenhouse gases from primary forest loss in the world. To reverse the trend, the Government of Indonesia is banking on carbon market mechanisms like the Reducing Emissions from Deforestation and Degradation (REDD+) programme. Geographers have made significant progress in detailing the relationships between private and public interests that enable REDD+. Less understood are the materialities of everyday life that constitute the substantive nodes - the bodies, the subjectivities, the practices and discourses - of political tensions and conflicts within Indonesia's nascent REDD+ implementation framework. Concerns for 'equity' rooted within an economistic frame of 'benefit sharing' seem to be high on political agendas. Yet, relatively few studies have investigated the basic principles and intimate processes underlying benefit sharing approaches within sites of project implementation.

Focussing on Sungai Lamandau, Central Kalimantan as a case study, I consider the powers local actors mobilise to access, and exclude others from the diverse and, at times, elusive set of 'benefits' within one 'community-based' REDD+ project. Reflecting on over 150 interviews and ten months of ethnographic observations, the exploration provides a timely alternative to overly reductive REDD + research, which remains focused on links between benefit sharing, safeguards, additionality, monitoring and verification. Instead it addresses the need to 'bring people back in', centring human agency within studies of REDD+.

The sometimes violent processes of access and exclusion, which occur within the Sungai Lamandau project, cut across conventional bounds of places and scales and are 
connected by political relations that traverse realms of intimate and transnational geopolitics. The thesis therefore proposes a feminist-inspired 'intimacy-geopolitics' as an analytical approach that connects seemingly close-knit and disparate people, places, and events orbiting issues of REDD+ implementation. I draw attention to the outwardly 'apolitical' (or 'a-geopolitical') realms of the body, the home, and intimate relationships as key sites where geopolitical power is (re)produced and challenged.

The thesis helps demonstrate the importance of dissolving the boundaries between the global and the local; the market and state; and the personal and political, within critical investigations of REDD+. Intimacy-geopolitics is used to articulate the inseparability of politics from economic, environmental and emotional geographies. Through such a framing this thesis uncovers the nuanced multi-local livelihoods of people as they adapt to violent upheavals, or make REDD+ part of a mix of options to clear paths towards more secure futures. While some farmers are able to counter their exclusion from benefits, others start to lose their precarious foothold on the land and must diversify their income sources as a result, with many bidding farewell to farming and forestbased livelihoods. The complex survival strategies, which this thesis helps make sense of, can be seen as both a cause of, and a reaction to, imposed social and environmental protections - a kind of 'everyday' counter-movement.

I suggest that REDD+ rooted in market logic, competition and individualism instills in people a nessesity for exclusionary practices. Masculinist models of REDD+ will therefore not only continue to fail in addressing the root-causes of anthropogenic greenhouse gas emissions, but will continue to be highly exclusive - disproportionately impacting women and those already marginalised. 


\section{ACKNOWLEDGEMENTS}

I had heard that, for many people, the road towards submitting a PhD thesis is a lonely one. I however have been blessed with a truly inspirational team of fellow researchers. Without the support of Rini Astuti and Rowan Dixon, the last several years would have been all the more laborious. I hope this is just the start of our long collaborative futures together.

I would like to thank all the research participants for their time, energy and patience, and for being so hospitable to me during my time in Sungai Lamandau. I would also like to thank all the staff and volunteers at Yayorin and the Clinton Climate Initiative. Trims banyak to all my new friends in Pangkalanbuun for your support and assistance, from helping me move into my beautiful barakan house to finding my moped. I want to extend these thanks far beyond Sungai Lamandau, down the river to the villages of Rimba Raya. It filled my heart with renewed hope for humanity when I arrived to such a hospitable and friendly bunch in the village of Baung. Thanks for teaching me how to tap rubber trees, catch fish and fix footballs with tree sap.

I would also like to thank the sponsors. The project was principally funded through a Royal Society of New Zealand Marsden Grant. I also received funding through two Victoria University Strategic Research Grants and a Doctoral Submission Scholarship.

I am grateful to all the staff in the Geography department at Victoria University for supporting me over the past three-years or so. I have been very lucky to have such enthusiastic and compassionate people around me. Special thanks to $\mathrm{Dr}$ Bethany 
Haalboom and Dr Marcela Palomino-Schalscha for your encouragement and support. Despite the significant spatial separations, Dr Suraya Afiff; Dr Sophie Bond; and Dr Ed Challies were also critically important in bringing this thesis together.

My supervisory team had a few substitutions along the way to submission. I am incredibly greatful to Dr Mike Gavin at Colorado State University for preparing me for life in the forests of Sungai Lamandau. I also appreciate the supervision, guidance and friendship of Dr Andrew McGregor. Thank you for putting so much trust in me to complete the most difficult (and the most interesting) part of the project.

Enormous thanks are reserved for my excellent primary supervisor and friend Dr Sara Kindon. You have always made me feel capable and motivated from day-one. I will miss our philosophical chats more than any other part of this experience. I hope we can continue them from wherever we end up.

I would like to thank Dr Derek Hall for sharing in a number of my ideas and giving some really valuable feedback. I would also like to thank all the anonynmous reviewers of various journal articles for their feedback and suggestions for improving things.

My family have been unfailing in their encouragement. My brother, Stephen particularly has been incredibly dependable.

HUGEST thanks of all to my 'wife' and Dr Who companion, Sarah. You turn each and every challenging moment into fun and excitement, and every moment of joy into something unforgettable. If it was not for you I would definitely be lost in the figurative (and literal) woods of Central Kalimantan. 


\section{CONTENTS}

ACSTRACT

\section{1 | INTRODUCTION}

1.1 THESIS RATIONALE \& RESEARCH QUESTIONS …................................................... 1

1.2 THESIS APPROACH \& CONTRIBUTIONS ......................................................................... 7

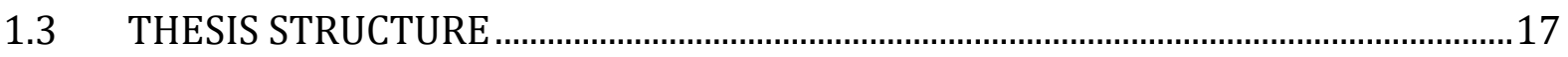

\section{2 | SEEING REDD IN A GREEN ECONOMY}

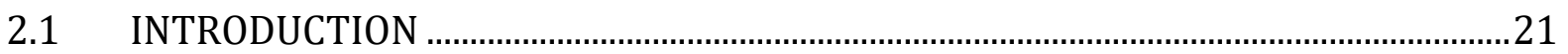

2.2 MAKING REDD+: CONTESTING THE VALUE OF FORESTS IN INDONESIA .............23

2.3 CONTEXTUALISING REDD+ IN SUNGAI LAMANDAU ................................................. 39

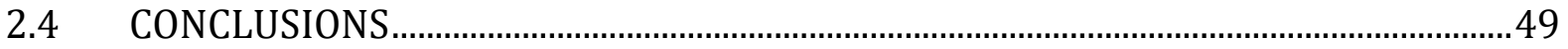




\section{3 | TOWARDS AN INTIMACY-GEOPOLITICS OF REDD+}

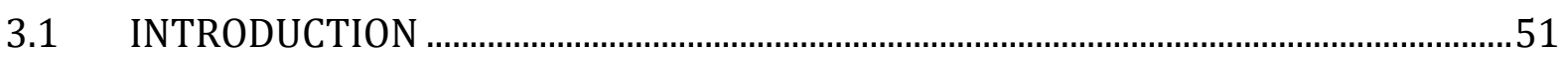

3.2 SELLING NATURE TO SAVE IT? ...................................................................................5

3.3 THE GREAT CARBON TRANSFORMATION ……………………………………………...56

3.4 AN INTIMACY-GEOPOLITICS OF REDD+ ....................................................................66

$3.5 \quad$ CONCLUSIONS

\section{4 | METHODOLOGY}

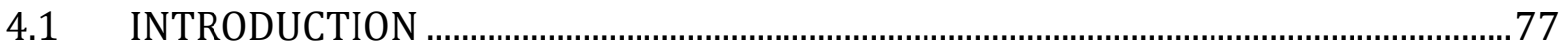

$4.2 \quad$ USING CASE-DRIVEN METHODS ………………………................................................

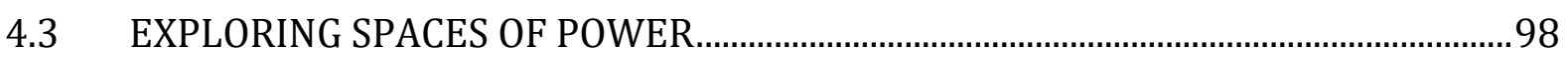

4.4 ANALYSING \& REPRESENTING SUNGAI LAMANDAU ...........................................115

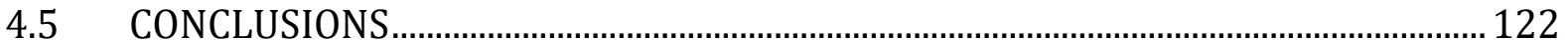

\section{5 | ANALYSING ACCESS TO REDD+ BENEFITS}

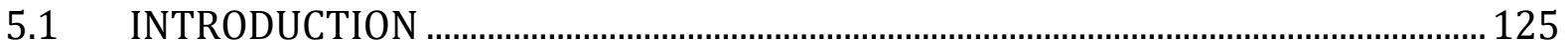

$5.2 \quad$ UNDERSTANDING REDD+ BENEFITS IN INDONESIA ...............................................128

5.3 CONCEPTUALISING ACCESS........................................................................................ 135

5.4 ACCESSING SUNGAI LAMANDAU'S REDD+ BENEFITS ............................................140

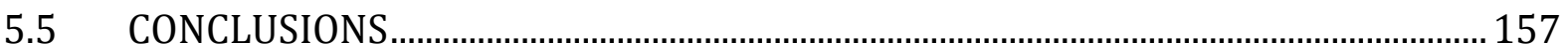




\section{6 | INTIMATE EXCLUSION}

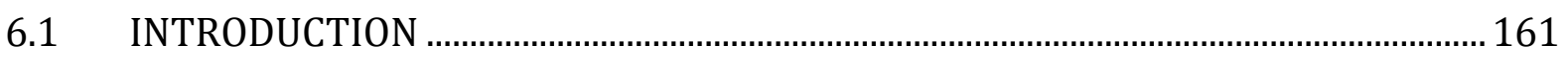

6.2 THE NEW ENCLOSURES WITHIN INDONESIA'S 'POLITICAL FOREST’ ….............. 163

6.3 CONCEPTUALISING INTIMATE EXCLUSION ……………………………………….... 172

6.4 INTIMATE EXCLUSIONS FROM SUNGAI LAMANDAU'S REDD+ BENEFITS............... 176

6.5 CONCLUSIONS

\section{7 | VIOLENT EXCLUSION \& COUNTER EXCLUSION}

7.1 INTRODUCTION 199

7.2 ASSEMBLING THE REDD+ FOREST FOR CAPITAL INVESTMENT ………………....202

7.3 CONCEPTUALISING VIOLENCE ................................................................................... 211

7.4 VIOLENT EXCLUSIONS \& COUNTER EXCLUSIONS IN SUNGAI LAMANDAU ....... 217

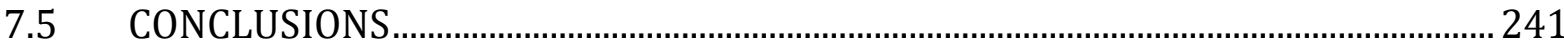

\section{8 | A FAREWELL TO FARMS?}

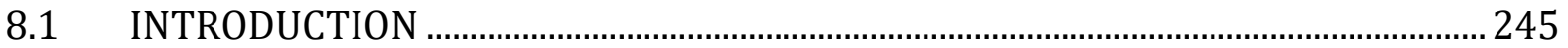

8.2 REDD+ IN THE TIME OF DEAGRARIANISATION ....................................................248

8.3 CONCEPTUALISING MULTI-LOCAL LIVELIHOODS …………………......................... 257

8.4 ACCESS TO AND EXCLUSION FROM BENEFITS BEYOND SUNGAI LAMANDAU.....261

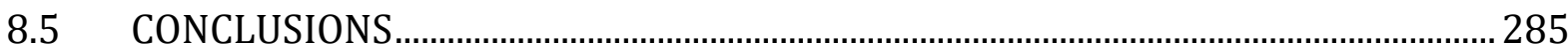




\section{9 | BEYOND REDD+}

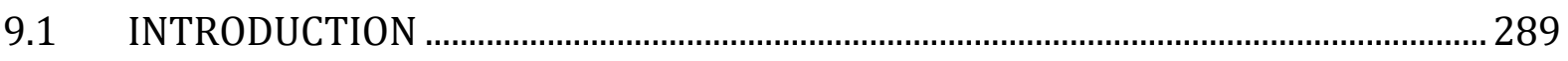

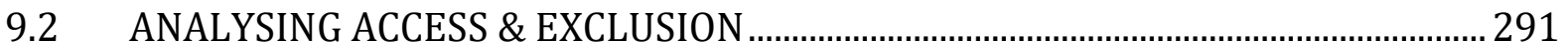

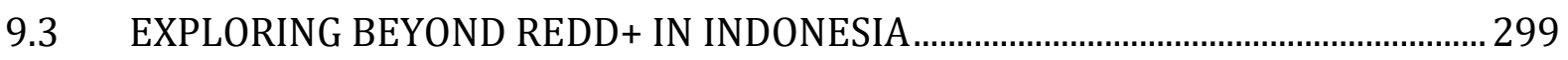

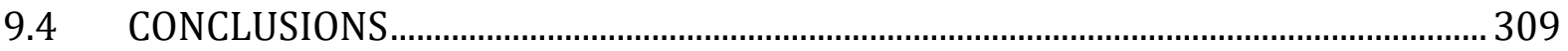

REFERENCES 


\section{FIGURES}

FIGURE 2.1: MAP OF CENTRAL KALIMANTAN, INDONESIA (SOURCE: AUTHOR) 37

FIGURE 2.2: DATA SHOWING FOREST LOSS ACROSS INDONESIA 38

FIGURE 2.3: MAP OF KOTAWARINGIN BARAT DISTRICT (SOURCE: AUTHOR). 41

FIGURE 2.4: THE REDD+ PROJECT ACTORS OF SUNGAI LAMANDAU 42

FIGURE 4.1: GOTONG ROYONG SESSIONS 91

FIGURE 4.2: ME, STANDING WITH YAYORIN VOLUNTEERS 105

FIGURE 4.3: SEI GANDIS GROUP MEETING SPACE AND PERIPHERAL SPACES 109

FIGURE 4.4: THE WOMEN OF WANITA MANDIRI

FIGURE 5.1: FOREST MONITORING TRAINING SESSION 150

FIGURE 6.1: THE UNLIKELY BEDFELLOWS OF REDD+ 164

FIGURE 6.1: "THANK YOU AND HAPPY STRUGGLING”. 229

FIGURE 7.2: "CARING FOR ORANGUTAN WEEK - WORLD TREE DAY". 237

FIGURE 8.1: PNPM INFORMATION BOARD 265

FIGURE 8.2: THE PENDULANGAN FIRE 271

FIGURE 8.3: WANITA MADIRI COLLECT NIPAH SUGAR. 278

FIGURE 8.4: DISTRIBUTING REDD+ INCENTIVES .282 


\section{TABLES}

TABLE 2.1: LIST OF VILLAGES \& SUB-VILLAGES ................................................................ 43

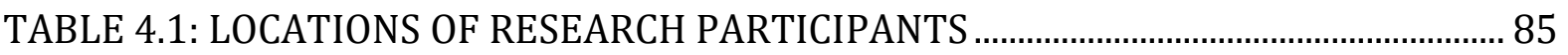

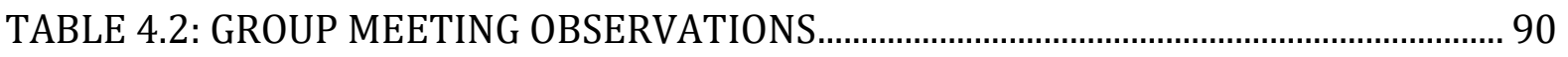

TABLE 4.3: SHORT INTERVIEW PARTICIPANTS................................................................. 93 


\section{ACRONYMS}

\begin{tabular}{|c|c|}
\hline AMAN & Indigenous Communities Alliance of Indonesia \\
\hline BPDAS & Provincial Forestry Department \\
\hline BPS & Central Statistics Corp \\
\hline CAS & World Bank's Country Assistance Strategy \\
\hline CCI & Clinton Climate Initiative \\
\hline $\mathrm{CDM}$ & Clean Development Mechanism \\
\hline CIFOR & Centre for International Forestry Research \\
\hline COP & Conference of the Parties \\
\hline DtE & Down to Earth \\
\hline FPIC & Free Prior Informed Consent \\
\hline GoI & Government of Indonesia \\
\hline $\mathrm{GtCO} 2 \mathrm{e}$ & Giga tonnes of Carbon Dioxide Equivalent \\
\hline HD & Village Forest \\
\hline $\mathrm{HKm}$ & Community Forest \\
\hline ICRAF & World Agroforestry Centre \\
\hline IMF & International Monetary Fund \\
\hline KBA & Kumpai Batu Atas \\
\hline KBB & Kumpai Batu Bawa \\
\hline KoBar & Kotawaringin Barat / West Kotawaringin District \\
\hline KTP & Identity card \\
\hline MK35 & Constitutional Court ruling on the rights of Indigenous peoples \\
\hline MoF & Indonesian Ministry of Forestry \\
\hline
\end{tabular}




\begin{tabular}{ll} 
NASA & United States National Aeronautics and Space Administration \\
OFI & Orangutan Foundation International \\
OFUK & Orangutan Foundation UK \\
PAM & REDD+ Policies and Measures \\
PDD & REDD+ Project Design Document \\
PERWANI & Union of Indonesian Women \\
PKB & Pelangi KoBar Bersatu / United Rainbow of KoBar \\
PKK & Welfare Development Movement \\
PNPM & National Programme for Community Empowerment \\
REDD +5 & Reducing Emissions from Deforestation and forest Degradation \\
RT & Elected neighbourhood official \\
SATGAS & REDD+ Task Force of Indonesia \\
SEMAKSI & Park Entry Permit \\
SES & Social and Environmental Safeguards \\
STRADA & REDD+ Provincial Task Force of Central Kalimantan \\
UNEP & UN Environment Programme \\
UNFCCC & UN Framework Convention on Climate Change \\
WWF & World Wildlife Fund \\
\hline
\end{tabular}




\section{INDONESIAN TERMS}

\begin{tabular}{|c|c|}
\hline Adat & Customary \\
\hline Arisan & Communal savings and loan scheme \\
\hline Bahasa & Language \\
\hline Barakan & Basic temporary lodgings \\
\hline Belum & Not yet \\
\hline Bersih & Clean / clear \\
\hline Bobrok & Dilapidated \\
\hline Bule & White European person \\
\hline Bupati & District Regent \\
\hline Danau & Lake \\
\hline Desa & Village / rural area \\
\hline Dinas & Office / bureau \\
\hline Emas & Gold \\
\hline Gotong royong & Voluntary work \\
\hline Hutan karbon & Carbon forest \\
\hline Jelutung & Native rubber \\
\hline Kabupaten & Regency / political jurisdiction \\
\hline Kami & Us (exclusive) \\
\hline Karet & Non-native rubber \\
\hline Kawasan Hutan & State Forest \\
\hline Kehutanan & Forestry \\
\hline Kelotok & Motorised river boat \\
\hline
\end{tabular}




\begin{tabular}{ll} 
Kepala & Head / chief / manager \\
Kerupuk & Fish-flour cracker \\
Kijang & Native miniature forest deer \\
Kita & Us (inclusive) / You and I \\
Kota & Urban area \\
Manis & Sweet \\
Nila & Fish - non-native (Cichlidae) \\
Patin & Fish - native catfish (Pangasiidae) \\
Perusahaan & Effort / enterprise / business \\
PolHut & Forestry Police \\
Rumah & House \\
Rusa & Native horned deer \\
Sama & With / together \\
Sei & River / tributary (Mendawai) \\
Suki asli & Original tribe \\
Sumpitan & Blow-pipe \\
Sungai & River / tributary (Indonesia) \\
Tengah & Central \\
Tidak pernah & Never \\
Tumbuhan & Plant / crop \\
Undian & Lottery / draw \\
\hline
\end{tabular}






\section{$\underset{\text { ONE }}{\text { CHAPER }} \mid$ INTRODUCTION}

\section{$1.1 \quad$ THESIS RATIONALE \& RESEARCH QUESTIONS}

In November 2014, NASA ${ }^{1}$ released a striking visualisation of how carbon dioxide flows around the world. In their simulation ${ }^{2}$, plumes of the greenhouse gas gush into the atmosphere from forests and major industrial centres, swirling incoherently from continent to continent on the winds of global climate systems. At times the red and purple clouds leap from the Earth's forested regions synchronously speed up and grow, enveloping nearly the entire planet, before suddenly fading, scattering to a benign blue or green haze as they land somewhere else. The seasonal migration of gases endlessly repeats itself as if the clouds were flocks of geese with secret social lives.

If one zooms in from this planetary perspective onto any of the major financial centres across the world, traders follow carbon visualisations of a different kind. Only a few pieces of linear information make it here: the bids, the volumes and the prices. A few horizontal lines (for selling and buying) circumscribe a winding line of up and down trends, enabling traders to bet on short term price movements. Carbon here is fully commodified. Just like other financial asset classes, it is as standardised, commensurable

\footnotetext{
${ }^{1}$ The United States National Aeronautics and Space Administration

${ }^{2} \mathrm{http} / /$ news.nationalgeographic.com/news/2014/11/141118-nasa-video-carbon-dioxide-globalwarming-climate-environment/
} 
and volatile as gold, oil and wheat. It moves in nanoseconds through circuits from a community-forest in Indonesia to a broker's firm in Chicago, before settling in a stock registry, writing off a day or two's emissions from a South Wales' steel works.

Forest carbon is as much a political category as it is a financial or chemical one. It is a contested and multiplicitous category with dynamic social meanings. As a commensurable unit of exchange, it is unfathomably complex. Just like other commonly traded commodities, its "social life" is encompassed by the situations that mediate its production, exchange and eventual consumption at different locations and times (Appadurai, 1986: 13). Yet, carbon is also mediated by guilt and fear. Efforts to generate political momentum for mitigating anthropogenic greenhouse gas emmisions are intensifying. Cautions are announced regularly concerning imminent climatic 'tippingpoints' and predictions of a future 'Planet of Slums' (Davis, 2006) - a desertifying global wasteland without predictable climatic conditions or conventional agriculture, with only small climate-protected pockets for the wealthy (see also Zhang et al., 2007; Steffan, 2008).

The causes of this impending climate disaster are numerous, but between fifteen and seventeen per cent of carbon emissions originate from forest-related activities (Denman et al., 2007). These emissions occur when forest carbon stocks are depleted and released to the atmosphere through changes in woody biomass; conversion of forests, peat lands and grasslands; forest fires; and abandonment of managed lands (Engel \& Palmer, 2008). Despite a national moratorium on deforestation licences, Indonesia remains the largest contributor of greenhouse gases from primary forest loss in the world, removing 840,000 hectares of primary forest each year (Margono et al., 2014). Nowhere are solutions to large-scale forest loss more urgently required. 
To reverse the trend, the Government of Indonesia (GoI) is banking on carbon market mechanisms like Reducing Emissions from Deforestation and Degradation (REDD+) (Indrarto et al., 2012). The REDD+ mechanism is designed to enable the provision of economic compensations, aimed at resource extractive industries, forest communities and governments, to protect forests by making them "more valuable standing than cut down" (Katerere, 2010: 105). In doing so, the mechanism promises to directly address the cross-sectoral drivers of forest loss in developing countries like Indonesia (Indrarto et al., 2012). It is also the first initiative to promise a way past three key contentious areas that have stalled other global forest agreements: (i) compensation for the 'opportunity costs' of forest conservation; (ii) the sovereign right of countries to determine their own priorities for development and conservation; and (iii) strong substantive requirements for protecting the environment, indigenous peoples and local communities (McDermott, 2014).

Despite these promises, REDD+ is loaded with a great breadth of meanings. The Centre for International Forestry Research (CIFOR) defines it both broadly and narrowly:

A broad definition, based on the official COP13 $3^{3}$ terminology, holds that REDD+ comprises local, subnational, national and global actions whose primary aim is to reduce emissions from deforestation and forest degradation and enhance carbon stocks (increase removals) in developing countries. A narrower definition is that REDD+ also includes results-based or conditional payments, which was a core idea when REDD+ was launched at the 2007 climate talks in Bali (Angelsen \& McNeil, 2012: 381).

\footnotetext{
3 The thirteenth Conference of the Parties to the United Nations Framework Convention on Climate Change, hosted in Bali, Indonesia (December, 2007).
} 
However, the mechanism has morphed considerably from how it was original conceived, from a tool to reduce emissions from land use change and forestry to a multifaceted scheme, redefining and reshaping human-forest interactions (den Besten et al., 2014). Yet, since national REDD+ policy development began, carbon storage has not been the primary objective (Indrarto et al., 2012). The process of enticing a diverse mix of project funders required an equally diverse set of promises.

There was substantial evidence that values of biodiversity conservation, equity and sustainable livelihoods were critical to the legitimacy and effectiveness of REDD+ carbon projects (Pistorius et al., 2011). They were therefore better viewed as prerequisites than as co-benefits, as first conceived (Visseren-Hamakers et al., 2012). Furthermore, while non-carbon co-benefits became increasingly important within many of the projects' deliverables, the persistent centralisation of REDD+ around carbon payments generated gaps between intentions and reality.

Many important learning experiences came from projects like the Kalimantan Forest Carbon Partnership activity, near Kapuas, which included conflicts over land tenure, sovereignty, forest dependency and carbon rights (see Lounella, 2015; Mulyani \& Jepson, 2015). Pant (2011) called for a more integrated REDD+ paradigm encompassing three pillars: (i) carbon; (ii) biodiversity; and (iii) community. In this paradigm, carbon would be repositioned as a 'bonus' should a viable market for it materialise (see Astuti \& McGregor, 2015).

Throughout these calls, significant debate remained about who should benefit from an incentive-based REDD+ mechanism and what the incentives should look like. Many poorly substantiated claims arose about who depends on forests and the link between forest-dependency and poverty alleviation (Belcher, 2012). Increasingly, commentators 
were recognising that underlying who should have (or could have) access to REDD+ benefits were social processes and relations, which connect actors across different material realities and geographical scales (Lohmann, 2009). These relations define who is entitled to the benefits, how much benefits are worth and which benefits accrue for which actors (Corbera \& Brown, 2010). Lindhjem et al. (2010) characterised two forms of benefit accrual. The first involved sharing benefits between global, national and local level actors; the second: within communities, households and other local actors. These categories are problematic when projects comprise a mix of economic and noneconomic benefits and may be impossible to apply equitably across geographic scales and distances. Understanding what these incentives look like for local actors and how they are accessed in places is essential.

In Indonesia, REDD+ is being presented as an effective and cost-efficient option for mitigating climate change (Neilsen, 2013). It seeks to reduce poverty and improve the lives of poor people by compensating them for not destroying forests and reducing their carbon emissions. Yet, in reality, large-scale commercial actors (not the poor) account for the largest share of deforestation (Rudel, 2007). Thus, the lion's share of funding should - following REDD+'s core principles - go to companies and people who are not poor. Nevertheless, preliminary observations of REDD+ policies suggest that these large commercial actors will not be fully compensated for their 'opportunity costs'. According to Bond et al. (2009), early lessons from REDD+ programmes suggest that they have, if anything, a pro-poor bias.

However, to say that REDD+ projects are, for the most part 'pro-poor' is misleading for two reasons. Firstly, it presumes that people who engage in forest-based livelihoods are 'poor'. Secondly, it presumes that people who live near or within a REDD+ project would 
have the capacity to actively engage and receive REDD+ project benefits. Much of the literature considers REDD+ benefit sharing as a cross-scalar matter of procedural and distributional equity. That conceptualisation has a significant blind-spot in that it misses out the micro-processes of intimate injustice and the consequences for local actors and their environment.

This thesis therefore, considers the powers local actors mobilise to access, and exclude others from the diverse and, at times, elusive set of benefits within one 'communitybased' REDD+ project in Indonesia. It explores the many ways in which power was wielded, yielded and negotiated. The case study is the Sungai Lamandau REDD+ project in Central Kalimantan, one from a portfolio of four REDD+ projects being supported by the Clinton Climate Initiative (CCI) forestry programme (between 2008 and 2013).

This exploration is guided by one central, and several supplementary, questions:

How do people actively engage within REDD+ projects in particular places?
a) What are REDD+ benefits in Sungai Lamandau?
b) How do people access the REDD+ benefits?
c) How do people exclude, or become excluded, from REDD+ benefits?
d) How do people respond to exclusion from REDD+ benefits?

In addressing these questions the study will show how environmental management rooted in market logic, competition and individualism instills in people a necessity for exclusionary practices. Alternative REDDs based on de-growth, re-commoning, ethicsbased management, or a not-for-profit economy are therefore required. The thesis argues that anything less permits the continued progression of market-based violences, land-use change and the ever-increasing degradation of Indonesia's tropical forests. 


\section{$1.2 \quad$ THESIS APPROACH \& CONTRIBUTIONS}

To answer these questions the thesis employs a post-structural feminist political ecology, which is now firmly established as an important area of enquiry within geography. The strength of political ecology lies in its capacity to direct attention towards many of the most important political and power-laden issues of our age: poverty, social justice, the politics of environmental degradation and conservation (Peet \& Watts, 1996), the neo-liberalisation of nature (Bakker, 2010) and ongoing rounds of accumulation, enclosure and dispossession (Sullivan, 2010; Cavanagh \& Benjaminsen, 2014; Matulis, 2014). Increasingly pluralistic in its conceptual moorings, the aims of political ecology include understanding the complex relations between nature and society through an analysis of access and control over resources and their implications for environmental health and sustainable livelihoods. It also aims to explain environmental conflict especially in terms of struggles over knowledge, power and practice, and politics, justice and governance (Watts, 2000). It is an approach that holds the potential for both 'hatchet and seed', offering critique by deconstructing and discarding dominant narratives in search of new alternatives (Robbins, 2012).

Political ecology is conceptually rooted in political economy, analysing the ways nature and labour are enrolled into producing things of value within systems of capitalist expansion (Robbins, 2012). Such political economy orientations were, in the 1970s, part of the radicalisation of geography (Golledge, 1973). During this period, positivist approaches to understanding the environment were intensely critiqued. Scholars from various disciplines rejected overly simplistic explanations of environmental degradation as simply poor management or cultural quirk (Peet, 2013). For them, the positivist approaches dominating geography could not adequately address the complexity of 
causes lying behind environmental problems. Žižek (2008) suggested that such positivist science had replaced religion as the location of truth.

Positivist approaches neglect the fact that scientific knowledge, like all knowledge, is imbued with relations of power, language and culture (Walker, 2007). Positivist science is therefore, one form of knowledge amongst many. The high position such positivism enjoys as the primary source of 'truth' within resource management approaches favoured by international institutions, has not always proved advantageous for global ecological systems or populations (Robbins \& Luginbuhl, 2007). Political ecology however, has always provided an analytical approach critical of science based on overly simplistic cause-and-effect calculations of environmental problems. These calculations often ignore the social factors that contribute to environmental degradation (Simon, 2008). Scholars of political ecology draw upon peasant studies and Marxist theory to explore the ways that processes and pressures produce environmental degradation (Peet et al., 2011).

Key theorists, including Derrida (1967), Foucault (1975) and Butler (1997) have become influential adding a post-structural dimension to political ecology. These theorists are attributed with developing an approach that examines how 'truths' are made and the links between knowledge and power. To analyse these links, poststructuralists often focus on discourse - the "specific ensemble of ideas, concepts, and categorisations that are produced and reproduced, and transformed in a particular set of practices and through which meaning is given to physical and social realities" (Hajer, 1995: 44). For the poststructuralist, meaning is constructed and is contingent, situated within certain contexts. There is, therefore, no true meaning outside of discourse. Furthermore, discourses are always malleable and unstable. As Gibson-Graham (2000: 96) states, the 
"creation of meaning is an unfinished process, a site of political struggle where alternative meanings are generated and only temporarily fixed". The naturalness of certain discourses is created and reinforced through the constitutive outside, the 'other' against which meaning is defined (Butler, 1990). The things that are excluded by discourses, however, are always present. Derrida (1967) describes this in terms of 'hauntologies', the idea that "all things that appear as 'being' or as 'being natural' - are haunted, and potentially disrupted, by that which has been excluded" (Braun \& Wainwright, 2001:57). I will explain this idea in some detail later in Chapter three.

Butler (1990) examined how these discourses produce effects. She explains this in terms of 'performativity' - the ways that discourses are practised and enacted in ways that produce what they name. She argues that meaning is shaped through repeated performances. Looking specifically at how identity is formed, Butler (1990) suggests that individuals make themselves legible to others by acting according to certain norms. Discourses take the form of internalised regulations that enable and/or constrain certain behaviours (Hajer, 1995). In other words, "what is performed always operates in relation to what cannot be performed or said" (Pratt, 2009:527). Restrictions on behaviour include who can and cannot participate in discourses and ask certain questions, what questions are relevant and comprehensible within the discourse and how a discursive order is maintained (Barnes \& Duncan, 1992). However, according to Pratt (2009), human agency is always possible within and through these performances because people are subject to competing discourses and the gaps between them. The 'haunting' presences create disjuncture and spaces for change. Moreover, the very idea of performativity (rather than identity, which is fixed), highlights instability whereby processes can disrupt and alter performances. 
Conversely, approaches drawing on Gramscian traditions often conjure up associations of dominance and control, invoking ideas of hegemony and resistance. Configured in this way, power is perceived as something exercised 'over', typically observed via a topdown dynamic. Taking a Foucauldian perspective, however, Allen (2004: 19) suggests a more spatially curious approach which "foregrounds associational as well as instrumental forms of power". Rather than conceptualising it as aggregated from a central point, Allen draws upon Foucault's argument that, since power is to be found everywhere, its sources are therefore diffuse. Instead of thinking of it in binary terms, Allen suggests that the modalities of power are constituted differently in space via a multitude of everyday practices, giving it an amorphous quality. Taking a less rigid approach in understanding the distribution of power resonates with scholarship on gender which has suggested that power is not something that is either experienced or practised by all women or all men in the same way, with 'femininity' and 'masculinity' existing in binary relation (Connell, 1987).

My understanding of power follows that of Allen (2004) - power as ever-present, concentrating unevenly, but not held in a fixed way (see also Kesby, 2007). This understanding of power enables a theorisation of how existing discourses are empowered, and new discourses emerge.

Rocheleau et al., (1996 see also Rocheleau, 2008) extended an analysis of power to include gendered relations, and to extend consideration of scales of analysis to include the household, thus complicating arenas of assumed common interest: 'community', 'local', and 'household'. She focused on three key themes: (i) gendered environmental knowledges; (ii) gendered environmental rights and responsibilities, and (iii) gendered environmental politics and grass-roots activism. In doing so she offered an open-ended 
and loosely configured framework that treated gender as "a critical variable in shaping resource access and control, interacting with class, caste, race, culture, and ethnicity to shape processes of ecological change, the struggle of men and women to sustain ecologically viable livelihoods, and the prospects of any community for 'sustainable development" (Rocheleau et al., 1996:4).

There has been an important shift in theoretical approaches to gender in the social sciences generally. Poststructuralist and performative approaches in feminist theory have challenged role-based and relational approaches to gender that rest predominantly on fixed notions of the autonomous subject, and that focus on men's and women's differentiated access to and control of environmental resources and socio-political processes (Butler, 2004). This is mainly because the intensification of economic reform programmes that favour market-led approaches to natural resource management are themselves not innocent of gendered power relations: they are inflected with gender discourses that set in motion differentiated and unjust life opportunities and exclusions (Elmhirst, 2011).

Since Rocheleau and her colleagues outlined the principles of feminist political ecology in the early 1990s, poststructuralist approaches to power, subjectivity and women's agency have grown in influence, placing the 'de-centred subject' at the heart of many debates (Butler, 2004; Radcliffe, 2006; Elmhirst \& Resurrección, 2008). This analytical strategy contributes to a feminist political ecology that emphasises subject formation in struggles around livelihoods, natural resource access and exclusion (Sundberg, 2004; Harris, 2006; Nightingale, 2006), where 'gender' is understood as a highly relational analytical concept for considering the workings of power, rather than as a descriptive term or categorisation (Butler, 2004; Cornwall, 2007; Elmhirst, 2011). Gender is 
therefore seen neither as analytically central nor as the end point of critique and analysis (Fraser, 2004). People are conceptualised as inhabiting multiple and fragmented identities, constituted through social relations that include gender, but also include class, religion, sexuality, race/ethnicity, as well as in multiple networks for coping with, transforming or resisting development (Nagar et al., 2002; Lawson, 2007). Of interest in much contemporary gender and environment work are how racialised or religious subjects are co-produced as gendered, and how such complex subjects of development are formed and act in relation to the exercise of power. The importance of this kind of approach lies in its ability to problematise the often naturalised and undifferentiated categories and social relationships between people and the environment.

It remains that in some instances, the label 'feminist' in gender and environment research carries unhelpful resonances and unwanted meanings (Wright, 2008). This is particularly so in contexts where postcolonial critiques complicate everyday understandings of feminism's meaning and intent, in ways that may prove unhelpful in engagements with the varied participants and audiences of political ecology research (Elmhirst, 2011). I use the label here explicitly to highlight a feminist ethic and commitment to critiquing and overthrowing oppressive structures of discrimination (see also Bell, 1993).

Through this commitment, the thesis adopts a feminist-inspired intimacy-geopolitics approach to an analysis of REDD+ in Sungai Lamandau. This analysis highlights the connections and relations between intimate actors and actions with that which is often considered geopolitical (Pain \& Staeheli, 2014). Such an approach attempts to dissolve the customary boundaries between global-local, familial-state and personal-political as objects of study. 'Intimacy' here does not simply concern dimensions of life taking place 
at close quarters, spatially and socially restricted to the self and a few known others. Neither is it limited to acknowledgement that non-intimate others are frequently involved in intimate relations. Instead it argues that the geopolitical is never separate from that which is intimate, and vice versa. This conceptualisation considers intimacy through sets of multiple intersecting relations, connecting the bodies of people in Sungai Lamandau with others more distant from them. This framing of 'intimacy' is explained further in Chapter four.

As the Sungai Lamandau activity was a 'community-based' project, it was a good case through which to explore the intimacy-geopolitics of REDD+ in spaces of implementation, focusing specifically on processes of accessing REDD+ benefits, and the associated exclusions. Exploring these processes required a reflexive ethnographic approach and feminist ethic of care along with activist engagement in the material and political struggles faced by the case study's diverse array of interests. The process of analysing the raw products (the texts) from my case-driven approach was both inductive and iterative. As data was collected and analysed I considered and reflected on emerging themes - emotions, fears, practices and interactions between nodes of REDD+ implementation across multiple scales of implementation. These themes were constantly reviewed as I interrogated the data and brought in opposing perspectives. The themes discussed are nuanced and interrelated and are therefore difficult to tabulate or render into quantifiable categories. As the thesis avoids a crude before-and-after REDD+ approach or a simplistic view of homogenous communities resistant towards a certain type of capitalist expansion, these themes cannot be boiled down easily into an allencompassing narrative with wholly positive or negative conclusions. 
My exploration of REDD+ takes a case-driven approach. Using interview methods which privileged the respondents' abilities and interests, it focuses on the particular lived realities of small-holders, labourers and project implementers in the study site. 141 semi-structured interviews, twenty-eight observations of group meetings, and twentyone short interviews were conducted in various settings. Local and national newspaper articles and statistical information were also collected as well as research reports from the 1990s to present day. Through this analysis, my role was to pursue and engage with theoretical and conceptual questions in ways that were always insistently and dialectically rooted in the struggles of everyday life.

Throughout my research I maintained a scholar-activist commitment to an ethical ideal (Cahill et al., 2007). A lens critical of market-based environmentalism was adopted, when appropriate, in order to privilege the vulnerable bodies of those at the sharp end of REDD+ interventions. This ideal attempted to interrogate and undermine the naturalness of market-based discourses within REDD+ implementation strategies, enabling alternative futures to be imagined that embraced a plurality of political possibilities. However, these commitments, like other aspects of my positionality, were not privileged at the expense of my trustworthiness. I adopted Mansvelt \& Berg's (2010) idea of 'trustworthiness' that is built through thick description. Thick descriptions go to the heart of a case study to explore peoples' experiences in that place, the meanings they make of the world, and the motivations that drive them.

Through the use of this approach the thesis provides numerous theoretical and practiceorientated contributions to knowledge within geography and beyond. Firstly, I add to the small, but growing, body of political ecology research that explores how REDD+ is manifesting in rural Indonesia. Scholars studying performance-based conservation have 
had difficulty establishing a clear link between theoretical discussions of capitalist expansion with case studies detailing the impacts of these projects in places and on certain populations (Yocum, 2013). My research offers a thick description of REDD+ commodity production within a 'community-based' setting to understand the nuanced impacts such projects have on capitalist power relations, natural resource management practices, and social and environmental justice.

Secondly, the thesis draws on recent calls to connect critical and practice-orientated research objectives. These argue that critical REDD+ research which is disconnected from practical matters can have perverse outcomes for practitioners who are ultimately working towards similar goals; while uncritical practice-oriented research has the potential to lead to a dilution of core values of environmental justice and conservation. In contrast, forms of practical critique provide ways of researching REDD+ that have practical value while maintaining critical insights (McGregor et al., 2014). Hardt (2011: 19) also maintains that "contemporary modes of critique are insufficient as political methods insofar as they lack capacity both to transform the existing structures of power and to create alternative social arrangements". The thesis therefore adopts what Woodyer \& Geoghegan (2012:206) call "affirmative modes of critique" that critically and creatively pursue what is socially just, in addition to identifying inherent wrongs. It adopts this approach in responding to Blaikie's (2012: 232) call for a more 'useful' political ecology that actively pursues environmental justice, in which "a focus on instrumental means of engagement outside the academy becomes essential".

Thirdly, it is widely held that where REDD+ 'touches down', at the local level, is where its effects would be felt most acutely (McGregor et al., 2015). However, albeit for a few remarkable exceptions (see Cavanagh \& Benjaminsen, 2014, for example), REDD+ 
related violence and resistance rarely constitute a loud and frenzied revolt in progress, but, are more often made up of semi-coherent whispers, misunderstandings and elusory chains of causation (Nel, 2014). This thesis therefore attempts to reveal the "humble and mundane mechanisms by which authorities seek to instantiate government" (Rose and Miller, 1992: 183). In doing so, it provides a timely alternative to overly reductive REDD+ research - which remains overly focused on links between benefit sharing, safeguards, additionality, measuring and verification (Sunderlin et al., 2013). Instead this thesis addresses the need to "bring people back in" (Rigg, 2012: 179), centring human agency within studies of REDD+. In doing so it highlights the 'hidden' nature of violent access and exclusionary arrangements instituted through REDD+ discourses as well as the causes and effects of these reactions. The many conceptual avenues pursued in the thesis are explained further in chapters five through eight.

Fourthly, the thesis goes beyond an 'opportunity cost' conceptualisation of localised REDD+ risk, which I argue is deeply flawed (see Gregersen, et al., 2010). It commonly presumes an either-or choice or 'zero-sum' game, whereby participation in one pursuit, prevents the possibilities for accessing another (see Skidmore et al., 2014 for example). That is not to say there are no risks associated with engaging in a REDD+ project. However, this thesis argues that they are better thought through an access-exclusion analytic because risks are often hidden and associated with dispossession from land and other resources.

Finally, it adopts a feminist-inspired intimacy-geopolitics lens (Pain \& Staeheli, 2014) to a study of the REDD+ mechanism in Sungai Lamandau. Troubling notions of intimacy serves to avoid the reification of existing geopolitical hierarchies, colonising knowledges and the dominance of 'market-based' valuations of forests. Such reinforcing is inevitable 
when thought through a standard market-environmentalist critique. This theoretical approach is detailed further in Chapter three.

\section{$1.3 \quad$ THESIS STRUCTURE}

The thesis is not structured so as to 'zoom-in' steadily towards a target for engagement. I do not wish to assume the existence of and prioritise an already present 'out there' over a messy and protean 'everyday' (see Pain \& Staeheli, 2014). Instead the thesis is structured to highlight the profound connections between the intimate access and exclusionary processes of everyday life in Sungai Lamandau with more diffuse practices of REDD+ implementation across scales. The relevant literature is critically reviewed throughout the thesis chapters. The thesis consists of nine chapters. This chapter has provided an introduction to the central research questions motivating this thesis and the key ideas and concepts with which I seek to engage. I also summarised my theoretical orientation, as well as the unique contributions the thesis makes to knowledge.

Following this, CHAPTER TWO outlines the context of REDD+ as part of an international 'green economy'. It then explores the meanings and modes of implementation of REDD+ in Indonesia generally and Sungai Lamandau specifically.

CHAPTER THREE offers a theoretical discussion positioning REDD+ discourses within a broader market-based environmentalism. In doing so it argues the case for a feministinspired reading of REDD+'s intimacy-geopolitics, a re-embedding of critical analysis, and the need for a radical re-scaling of REDD+ scholarship. It also lays out the novel analytical framework used throughout the thesis' core chapters. 
CHAPTER FOUR explains how I conducted this investigation in a way that navigated commitments to doing ethical and accountable research in an often challenging and high-stakes, but deeply rewarding, context. It explains what it has meant to do research in a feminist poststructuralist way that also works to be decolonising. I describe how I understood myself within REDD+ knowledge production, as well as my orientation towards activist scholarship. Throughout, I examine the challenges and rewards of adopting an approach to research ethics beyond formal university processes. I also describe the research methods I used to explore how access to and exclusion from REDD+ benefits played out in different places.

CHAPTER FIVE ${ }^{4}$ takes a close look at the social dynamics within the Sungai Lamandau project as people actively engaged in REDD+. The chapter examines the wants and needs of people as the REDD+ 'benefits' in question. It provides a rich understanding of how different types of local actors, such as various small-holders, farm-labourers and women's groups, have sought to access these benefits. Entrenched local power dynamics and social relations are shown to shape how people achieve this, with some using REDD+ to challenge or subvert existing structures and others using them to strengthen their positions. It shows that project developers only contribute part of the story of REDD+. The agency of local groups also has a substantial impact on how the project unfolds.

CHAPTER SIX ${ }^{5}$ explores the micro-processes of accumulation and dispossession in Sungai Lamandau. In doing so it charts the diverse array of ways individuals have both been excluded, and have excluded others, from land and the REDD+ benefits wrapped-

\footnotetext{
${ }^{4}$ An earlier version of this chapter was published as Howson \& Kindon, 2015.

${ }^{5}$ An earlier version of the chapter has been presented at the Green Economies of the South conference in Dodoma, Tanzania and submitted for publication to the Conservation \& Society Journal.
} 
up in it. The conceptualisation of exclusion used here, does not simply take exclusion as something negative, counter-posed with the positive idea of 'inclusion', but rather as something inevitable. The paper focuses on 'intimate' exclusions, showing how contests over land control in Sungai Lamandau were not over land use per se, but rather over power, property rights and social safety nets.

Those excluded did not disappear quietly. CHAPTER SEVEN 6 explores the various counter-exclusions constituted within the REDD+ project's violent access controls and property-making arrangements. Using a broadened violence heuristic, the chapter focuses primarily on the 'everyday' violences and dissimulative efforts of labourers to covertly protest, disrupt, and shape the project's benefit sharing arrangements. In doing so, the chapter shows how deforestation and forest degradation resulted through processes of violent counter-exclusion. Without an understanding of how exclusion and counter-exclusion are constituted within benefit access arrangements, the Sungai Lamandau REDD+ project may fail to address (or even exacerbate) social inequalities and environmental violence - root causes of Sungai Lamandau's forest degradation. As the community-based model instituted in Sungai Lamandau is intended for roll-out across the region, it is imperative that the potential environmental violence in instituting it is recognised and understood, as well as the implicit violence that precedes it.

For some people, their responses to REDD-related exclusions were to leave farming and Sungai Lamandau altogether. CHAPTER EIGHT therefore, looks at people's changing relationships to land in the project site, which had far-reaching, yet poorly forecasted implications for the project's development outcomes. In doing so the chapter shows how some Sungai Lamandau farmers bridged the contradiction between needing to

\footnotetext{
${ }^{6}$ An earlier version of the chapter has been presented at the Association of American Geographers Annual Meeting in Chicago, (2015) and submitted for publication to the Journal of Critical Asian Studies.
} 
demonstrate legitimate entitlement to REDD+ benefits - through claims of socio-spatial 'fixity' and attachment to Sungai Lamandau's forests - and the need to move, to explore opportunities in other locales, creating multi-local livelihood strategies.

Finally, CHAPTER NINE ties together the research implications of the thesis. It reflects on the theoretical and methodological framework used, exploring what worked well and the limitations of the study. The chapter calls for attention to be redirected towards alternative REDDs based on de-growth, re-commoning, ethics-based management, or a not-for-profit economy. It argues that anything less permits the continued progression of market-based violences, land-use change and the ever-increasing degradation of Indonesia's tropical forests. 


\section{CHAPTER SEEING REDD IN A TWO GREEN ECONOMY}

\section{$2.1 \quad$ INTRODUCTION}

Advocates of REDD + hope that markets in biodiversity and carbon offsets can help to surmount the tensions between seemingly contradictory goals: slowing global warming and promoting economic development (Le Blanc, 2011). Through this reasoning REDD+ has been constructed as the first multilateral agreement (agreed at least in principle) for global action on climate change, since the adoption of the 1997 Kyoto Protocol. Advocates envision that REDD+ will benefit all parties: governments and land users, private investors, and humanity as a whole (Luttrell et al. 2013 in McAfee, 2015). The mechanism is part of a wider green economy shift in market-based principles (Lohmann, 2012). In line with the conventional economic theory that informs most green economy thinking, markets in carbon-sequestration and other ecosystem services are seen as an economically efficient means of mitigating climate change and conserving biological diversity, without curtailing economic growth (Fairhead et al., 2012).

Despite the advocates' promises of providing benefits for all, modes of implementing REDD + are disparate. No two REDD+ projects are ever the same (Nel, 2014). Indonesia's 
array of REDD+ projects are particularly diverse, requiring a critical analysis of local nuances and politics of place to understand the different ways REDD+ is playing out.

This chapter outlines the context of REDD+ implementation in Sungai Lamandau. In doing so the chapter emphasises the position of the project within an international green economy paradigm. It explores the meanings and modes of implementation of REDD+ in Indonesia generally and Sungai Lamandau specifically as well as the nuances of villagelevel politics. It does so while calling into question the centrality of biophysical ecology, viewing Sungai Lamandau's 'environment' as a question of knowledge and representation as well as biophysical nature. Political Ecology rests on the dialectical and non-linear relations between nature and society in which the environment can be approached in a number of ways (Watts, 2000). This chapter attempts to examine 'everyday' knowledges of the environment and why and how particular forms of knowledge predominate in Sungai Lamandau. This summary of the political nuances of 'everyday life' in Sungai Lamandau is of course a general one. However, it is useful in providing a foundational understanding of local conditions and how they connect with wider processes of green economic expansion across multiple scales of REDD+ implementation. 


\subsection{MAKING REDD+: CONTESTING THE VALUE OF FORESTS IN INDONESIA}

\subsubsection{GLOBAL PROBLEMS NEED GLOBAL SOLUTIONS?}

Stern stated in his famed 2006 report that "climate change presents a unique challenge for economics: it is the greatest and widest ranging market failure ever seen" (Stern, 2006: 27). Atmospheric carbon, in Stern's view, is an under-internalised externality of production. Despite these acknowledgements of the market's failures to prevent these crises, the market remains central to global climate change governance. Carbon markets in the form of cap-and-trade off-setting mechanisms and voluntary emissions trading are still commonly held as the most economically efficient, and therefore most desirable, means of engagement (Petherick, 2011).

The linkages between environmental governance and global financial markets have been clear for many years. New ways of expanding the money supply allowed for the enormous capital accumulations observed before (and after) the 2008 global financial crisis. Creative mechanisms for profiting from potential future market values were to find a slot in the 'global solution' for climate change (Dixon \& Challies, 2015). Following the 'success' of the financial derivatives markets, Sandor, a US economist and trader who was one of the originators of interest rate derivatives in the 1970s, helped develop the idea of pollution trading in the 1980s and 1990s. This idea was built on theoretical foundations laid down by neoclassical economists such as Coase (1960). Sandor's Acid Rain Programme was a market-based initiative taken by the United States Environmental Protection Agency in an effort to reduce overall atmospheric levels of sulphur dioxide $\left(\mathrm{SO}_{2}\right)$ and nitrogen oxides, which cause acid rain (Sandor et al., 2002). 
The programme was an implementation of emissions trading that primarily targeted coal-burning power plants, allowing them to buy and sell emission permits according to individual needs and costs. Title IV of the US Clean Air Act (1990) set a decreasing cap on total $\mathrm{SO}_{2}$ emissions for each of the following several years, aiming to reduce overall emissions to fifty per cent of 1980 levels.

Proposals for dealing with $\mathrm{CO}_{2}$ in the same vein were rife. Furthermore, US legislatures restricted themselves from any non-market based alternatives for dealing with US greenhouse gas emissions - then the highest of any single nation. In July 1997, fivemonths before the Kyoto summit, the US Senate passed the Byrd-Hagel resolution. The document was not legally binding; rather, it was a 'sense-of-the-Senate' resolution passed by a 95-0 vote. It stated that:

[T] he United States should not be a signatory to any protocol [...] which would (a) mandate new commitments to limit or reduce greenhouse gas emissions for the Annex I Parties, unless the protocol also mandates new specific scheduled commitments for Developing Country Parties within the same compliance period, or (b) result in serious harm to the economy of the United States (US Congress, 1998: 1).

In December 1997 the Bill Clinton regime, citing the precedent of the US programme to trade $\mathrm{SO}_{2}$, successfully pressed for the United Nations' Kyoto Protocol to become a set of global pollution trading instruments (Mitchell, 2009). These instruments were ostensibly modelled, as was the US Acid Rain Allowance system, on the global futures markets (Lohmann, 2012). Clinton later said of the achievement: 
I'm particularly pleased at the agreement. It strongly reflected the commitment of the United States to use the tools of the free market to tackle this problem. We got what we wanted, which is joint implementation, emissions trading, a market orientated approach. It's a huge first step. And I did not dream when we started that we could get this far. We should be very, very proud of this. (Former US President Bill Clinton, 1997 in Heinemann, 2013:6).

\subsubsection{REDD IN A GREEN ECONOMY}

Three Kyoto mechanisms were established, including: i) International Emission Trading; ii) the Joint Implementation flexibility mechanism; and iii) the Clean Development Mechanism (CDM). The CDM had two broad objectives: First, to provide a 'cost-effective' mechanism for the developed world to offset greenhouse gas emissions, and second, to contribute to sustainable development by transferring new low carbon technologies to developing countries that host CDM projects. It therefore provides the only formal link between the annex-one - 'developed', and non-annex-one - 'developing countries' in the Kyoto process (Grubb et al., 1999). Yet, the mechanism had no facility for financially incentivising the reduction of tropical deforestation and forest degradation - the leading source of $\mathrm{CO}_{2}$ emissions in most non-annex-one countries.

The idea of creating a mechanism to prevent forest degradation in developing countries, was high on political agendas. In 2005 'REDD' was proposed through the UN Framework Convention on Climate Change (UNFCCC) by a small group of national representitives (or 'climate negotiators') led by Papua New Guinea. These negotiators called themselves 
the Coalition for Rainforest Nations. Various Payments for Ecosystem Services (PES) methodologies were already well established as a governance tool, in particular in Latin America (Engel et al., 2008; Fisher et al., 2009; Norgaard, 2010). What was new with REDD was that payments were to be made on a massive scale in potentially almost every tropical forested country and made available on a long-term basis with very stringent monitoring and verification (McGregor, 2012).

The 'services' to be delivered, primarily in the form of 'saved carbon', could potentially be sold through a market as offsets for countries with emission reduction targets (Angelsen et al., 2009). Due to political pressure from some developing countries, there was a consensus that REDD should not only compensate for avoided deforestation and degradation, but should also incentivise sustainable forest management and enhancement of forest carbon stocks (this brought about the ' + ' in REDD+). The idea was to set up economic incentives so that local, national, and international actors would have greater interest in protecting a forest (including its carbon stock) than in cutting it down (Eliasch, 2008).

The critical question was whether the whole mechanism should be market-based or fund-based. If the market model was chosen, REDD+ activities in developing countries would, at least partially, be eligible for offsets in industrialised states and thus resemble the CDM. Various academic contributions (see Eliasch, 2008 for example), most practitioners and most developing countries favoured such a market-based approach, some stressing the argument that only markets would, in the end, provide sufficient incentives and generate enough resources to actually stop deforestation (Kindermann et al., 2008). The amount of money required to finance REDD+ was considered to be 
around US $\$ 30$ billion per year (McGregor, 2012). Furthermore, the administrative costs would most likely raise the price substantially (Corbera et al., 2010).

CDM and REDD+ as offset mechanisms remained justified through the economic rationale that emissions are global externalities and that it did not make a difference where they were being reduced. If a stringent cap was set on emissions, it was possible to let the forces of supply and demand determine where reductions should take place (Lederer, 2011). By 2012 the CDM had apparently 'offset' about $2.6 \mathrm{GtCO}_{2 \mathrm{e}}$, "approximately the total emissions of Germany for three consecutive years" (ibid, 2011: 1902). Yet, despite this apparent success, the Kyoto mechanism with carbon trading as its cornerstone, failed to reduce global anthropogenic emissions. The failure of carbon markets is clear. Despite their ability to disingenuously account for some national emission reductions, global $\mathrm{CO}_{2}$ concentrations have not been as high as they are today since at least the advent of the Paleocene-Eocene Thermal Maximum, about 55.8 million-years ago (Cronin, 2010).

Resistance to such market-based tools frequently stems from the belief that economic valuation does more to promote uneven accumulation of wealth and extends the reach of global capitalism than it does to expand sound ecological management (see also Brockington \& Duffy, 2010; Corson, 2010; Matulis, 2014). The Kyoto protocol's carbon credit schemes have increased global emissions by approximately 600 million tonnes (Schneider \& Kollmuss, 2015 see also Morales \& Vitelli, 2013). The spectacular 'failures' of carbon markets to have any effect on climate change or create robust, socially inclusive financial commodities are, viewed from the perspective of capitalist interests as spectacular 'successes'. They create the need for more 'technical' work and delay action on fossil fuel use, deforestation and global mass consumerism (McGlennon, 2015). 
When the only tabled alternative is so similar to 'business-as-usual', to the extent that one cannot easily tell the difference, one has to question whether that really does constitute an alternative course.

It has become increasingly clear that forest carbon valuation mechanisms like REDD+, act not as alternatives to a 'business-as-usual' societal condition, but as a requirement for it. In this zeitgeist of 'crisis capitalism' (see Klein, 2008), climate change itself has become a major new frontier of value creation and capitalist accumulation. In her book, The Shock Doctrine, Klein argues that various crisis events, from natural disasters to terrorist attacks, in fact are central to the creation of the openings required for incursions of corporate capital investment, thinly masked by the seemingly liberating guise of instituting free markets and democracy (Klein, 2008). Fletcher (2012) suggests that the growing effort to address anthropogenic climate change through carbon markets and other financial mechanisms constitutes the same form of market neo-liberal manoeuvring. Such characterisations of the climate crisis as a new business opportunity have multiplied in recent years. As one of many examples, financier Fink asserted in September 2008, at a gala banquet in support of Prince Charles' Rainforest Project:

Leaving aside the immeasurable value offered by our rainforests' diversity and water conservation functions, we are facing an almost unfathomably large business opportunity, one which we can share with the Rainforest nations of the world. [...] With an estimated 610 billion tonnes of $\mathrm{CO}_{2}$ sequestered by our tropical rainforests, a vast $\$ 18$ trillion business opportunity is before us (in Brockington and Duffy, 2010: 469).

Juniper's (2012:1) proposition that "we must put a price on nature if we are to save it" is now a questionable one. A break from the routine of market fundamentalism offers more 
hope. As Klein (2015) argues, there are probably no non-radical solutions left for mitigating climate change. Despite some REDD+ projects proving to be sensitive to the concerns of a broad range of traditionally disadvantaged actors (see McAfee \& Shapiro, 2010; Pham et al., 2014), the proposition for tweaking the framework of market-based instruments, are arguably no longer on the table (Matulis, 2014). We must now pay what Mann (in Klein, 2014: 87) calls "a huge procrastination penalty when it comes to emitting carbon into the atmosphere": the longer we wait, the more it builds up, the more dramatically we must change to reduce the risks of catastrophic warming.

Sandor (2012: 145) tells us exactly why carbon markets cannot be left to manage carbon. He describes in his book The Good Derivative, why exactly the carbon price dropped from US\$7.4 in mid-2008 to US $\$ 0.5$ by the end of 2010 :

The system in fact was working as designed. The market [...] was reflecting reality - the total lack of political will to meaningfully manage global warming. Markets have eyes.

\subsubsection{REDD+ IN INDONESIA}

Within Indonesia specifically, critical voices were raised expressing worries that REDD+ initiatives could potentially deprive 'forest-dependent communities' of access to customary forestlands and that more powerful players would capture the stream of benefits of future carbon offsets (Peskett, 2011). Despite this, Indonesia along with twenty-five other countries signed the UNFCCC's Copenhagen Accord in December 2009. The accord set targets of twenty-six per cent domestic emission reductions by 2020 and forty one per cent with international support (Astuti \& McGregor, 2015). The largest 
contributions to achieving these goals were expected to come from the forest sector. Enticed by large bilateral and multilateral donor investments, the Indonesian government in 2009 officially confirmed its participation in the UN-REDD+ programme and multiple demonstration projects were initiated throughout the archipelago with support from international NGOs, bilateral donors and the private sector (Dixon \& Challies, 2015). In 2015, Indonesia had close to seventy-five REDD+ demonstration projects, a number that will probably grow in the years to come (GCP, 2015). Before I consider the context of Sungai Lamandau explicitly, it is helpful to fix a wider lens on land-use change and natural resource management, as well as gender issues in Indonesia generally. The intimate workings of REDD+ can only be sufficiently made sense of through an understanding of the gendered nature of Indonesia's economy.

The forms of access to, and control over, forest resources in Indonesia have changed significantly along the Nation's, as yet unresolved, road to a decentralised governance structure. The enclosure of land and resources by Indonesian central state institutions and the state's failure to reinvest in the source regions was a major source of contention for outer-island provinces in Indonesia under Soeharto's New Order regime (1966 - 98) (Howson \& Kindon, 2015). In particular, the Kawasan Hutan (state forest) enclosures starting in 1980, created the legal mechanisms for a major jurisdictional shift from outer-island regions to centralised resource management by the national government. Laws created a state forest zone across seventy per cent of Indonesia's land base, effectively eliminating local, district, and provincial roles in resource management (Peluso, 2007). Indonesia's state institutions thus became the nation's largest landlord, with the Ministry of Forestry becoming the primary beneficiary. 
These strategies, designed to increase agricultural output, together with other development interventions, was part of the regime's desire to make Indonesians economically 'modern' (Rigg, 2007). Through this process of modernisation, the family was to be at the heart of the regime's strategy. Yet, this resulted in familial impositions through the ideology of 'State Ibuism'7 (see Djajadiningrat-Niewenhuis, 1987). In addition, the promotion of female domestic servitude was promoted within a more nucleated and geographically mobile family (Hugo, 1995; 2002). Through its reformation of the PERWANI model (Persatuan Wanita Negara Indonesia - Union of Indonesian Women's movement of the late colonial Dutch period) - the New Order regime set out to incorporate the role of women into a national development plan. The new Family Welfare Guidance Movement (PKK) was charged with harnessing women's organisational activities to stated government objectives. Female leaders were tasked with linking the predominantly male-designed development theory and ideology with its female zone of implementation (Suryakusuma, 1991; Kindon, 1993).

The movement led to limited political power for female members. The contemporary PKK ideology, of which the modern housewife was the backbone, did not change the political status of women vis-à-vis men at any level of Indonesian society (Fakih, 1996). Old Javanese gender distinctions were sanctioned and reinforced, while identifying a special area of national development for women. The influence of PKK ideology spread as geographically mobile Javanese families were transplanted across Indoensia's outer islands, including Kalimantan, as part of the state-sponsored Transmigrasi programme. PKK ideology redefined women's place even more narrowly in the private family sphere.

\footnotetext{
7 Suryakusuma (1991) introduced the term 'State Ibuism' to encapsulate how the New Order government used constructions of acceptable gender and sexuality as a form of social control.
} 
For some, it sought to confine women more strictly within the home, editing out their age-old roles in subsistence sectors of economic life (Goetz, 2007).

Soeharto, the state patriarch, was unsaddled when in 1997 a crisis of international market confidence in the Thai Baht precipitated a chain of events which unravelled the Indonesian economy and collapsed its corporate and financial institutions. Faced with massive civil unrest, Soeharto accepted an International Monetary Fund (IMF) bailout package and the structural adjustment conditions the IMF imposed, including significant cuts in government spending on food subsidies and other social services. For a short time the markets stabilised, before the IMF capital found its way to back to foreign investors leading to further market turmoil (Robison \& Hadiz, 2004). In 1998, amidst massive public protests against him, Soeharto resigned.

Despite the collapse of the Soeharto regime, many development practitioners seriously underestimated the stickiness of pre-existing power relations. The focus on 'getting the institutions right' neglected the reality that economic policy institutions were the product of hard-fought and shadowy political conflicts (Brockhaus, 2014). The subsequent years of decentralisation, which many hoped would bring real change, created opportunities for local notables and coalitions, but all too consistently these gravitated to the rationale that continues to animate the system as a whole - the appropriation of state power as a source of self-reproducing patronage directed to the advancement of private interests (Robison \& Hadiz, 2004).

The structural shocks of the economic crisis and the collapse of the Soeharto regime have produced half-hearted and clumsily implemented measures of market reform. As power became decentralised and political parties and electoral competition grew in importance, Indonesia's outer islands saw increased predatory patterns of state- 
business relations previously organised around Jakarta (Hall, 2013). The district Regents (Bupati) obtained key powers within networks involving local businesses, brokers, investors, local populations and large corporations. The Bupati's office was endowed with planning and licencing powers which bypassed the central and provincial tiers of government. The Bupati's office became tasked with attracting investors and delivering the maximum development benefits for his or her constituents. Though companies seemed to be largely absent in these networks, their interests were strongly reflected in government language and decisions, suggesting that private sector lobbying continued to have a significant impact in local decision making. As Brockhaus (2014: 1) states, "This is something we see everywhere in Indonesia and is basically a result of lobbying, there's the policy network that you can see, and there's the one that exists but you don't see - the shadow network".

With decentralisation came the World Bank's Country Assistance Strategy (CAS). The strategy held the belief that restored rural communities could provide the backbone of an invigorated civil society that would exemplify good governance practices based on competition and choice. The CAS suggested that governance was Indonesia's key medium-term development challenge, which when broken down into its components (corruption, lack of accountability, transparency and rule of law) could be easily rectified by tweaking the design (World Bank, 2002). Research associated with the CAS concluded that the way for villagers to improve their condition was by reforming local-level governance, beginning with improved local planning and project implementation. The neo-liberal policy argument was that improved well-being was within the grasp of responsible communities that made appropriate choices (Li, 2007). Part of the strategy involved the provision of block grants of up to US\$110,000 to Kecamatan (sub-districts), 
where committees adjudicated between proposals for competing infrastructure or small enterprise loans for village community groups. Targeting credit programmes to the poorest (and therefore, the most needy) citizens proved problematic. Loans were made only to the most viable enterprises at standard market rates. Despite this, repayment rates were commonly very low (World Bank, 2005).

These local empowerment strategies were not empowering in any economic sense raising rural incomes had been abandoned as an indicator for measuring project successes, due to difficulty with monitoring procedures (Li, 2007). Instead, the implementation had a transformative agenda, with project funds acting as leverage to encourage and reward obedience to a detailed set of rules. Village community groups were required to form committees, hold consultations and interact through formalised meetings (Guggenheim, 2004). To navigate these innovative forums through the required hoops, new local civil society organisations provided facilitation services with funding available through the strategy fund. Many other international development funds soon opened up to fund a variety of 'community development' and forest protection projects across Indonesia. Large international NGOs, like the Orangutan Foundation International (OFI), were required to work through locally regulated partners, like the Orangutan Foundation Indonesia (YAYORIN). Later this requirment was relaxed, allowing international NGOs to act more independently.

Although recent data suggest a slight declining trend due to these reformed direct investment pathways, deforestation rates over the past three decades have been high: 2.7 per cent per year in Sumatra and 1.3 per cent in Kalimantan during the period 20002010 (CIFOR, 2013). Activities that directly contribute to deforestation and forest degradation include conversion of forests to other uses such as agriculture and mining, 
illegal logging, and forest and land fires, the latter often associated with drained peatlands. These activities are driven by, among others, high demand for forest-based products in both domestic and international markets and weak governance systems at national and subnational levels (Indrarto et al., 2012). Forest cover decline is also associated with natural population growth and demographic change such as that resulting from transmigration programmes (Potter, 2012).

Ultimately, deforestation is intricately linked to the structure of the Indonesian economy, which continues to be dependent on the extraction of natural resources. This dependence has shaped the political economy and institutional landscape of the country. The issues are systemic, expansive and complex, and, according to CIFOR, include capacity constraints and poor governance of land use-related institutions, unclear spatial planning processes, and frequent land and resource tenure conflicts (CIFOR, 2013).

In 2007 Indonesia started its REDD+ readiness process through a pursuit of international development revenue and a response to the limited opportunities to capitalise on incentive based forest protection schemes under the Kyoto Protocol (den Besten et al., 2014). The inevitable hangover from an unfinished decentralisation project however, resulted in an abundance of problems: forest boundary disputes, concession overlaps and corruption were typically found across all the forested provinces (Indrarto et al., 2012; Astuti \& McGregor, 2015). With the complexities and claims of cross-sectoral bureaucracies, came delays in the readiness process. Nevertheless, REDD+ was positioned as a key element in realising Indonesia's presidential pledge towards a twenty-six percent reduction in emissions by 2020 or forty-one per cent with international support (Indrarto et al., 2012). With the expectation that REDD+ would 
deliver monetary incentives for emission reductions (Wemaere et al., 2009) the concept of 'carbon rights' - the ability to own the rights to forested land's utility, if not the land itself - became a new arena for both contest and cooperation in the political struggle for access to potential project benefits (Galudra et al., 2011).

Despite easing of centralised control over the state forest zone, very little control of land for REDD+ in Kalimantan and other outer islands has been passed to community groups or locally managed cooperatives. In 2010 the Ministry of Forestry set itself a target of creating 1,600,000 hectares of community forest land (HKm) by 2016. Yet, a current nation-wide shortfall of 850,000 ha (fifty-three percent), is leaving many community cooperatives in Central Kalimantan feeling short-changed (see Howson, 2013; Howson \& Kindon, 2015). Legal manoeuvring from indigenous rights groups such as the Indigenous Communities Alliance (AMAN) has forced nodes of government to relinquish some control of land for the communal management of indigenous small-holders. Indonesia's Constitutional Court ruling in May 2014, referred to as the MK35 ruling, resulted in hutan adat (customary forests) no longer being categorised as hutan negara (state forests), instead becoming hutan hak (forests subject to rights). This meant hutan adat, while still subject to the jurisdiction of the Ministry of Forests were considered to be areas where communities had stronger claims to land and to manage resources (DtE, 2014) (see Figure 2.1). 


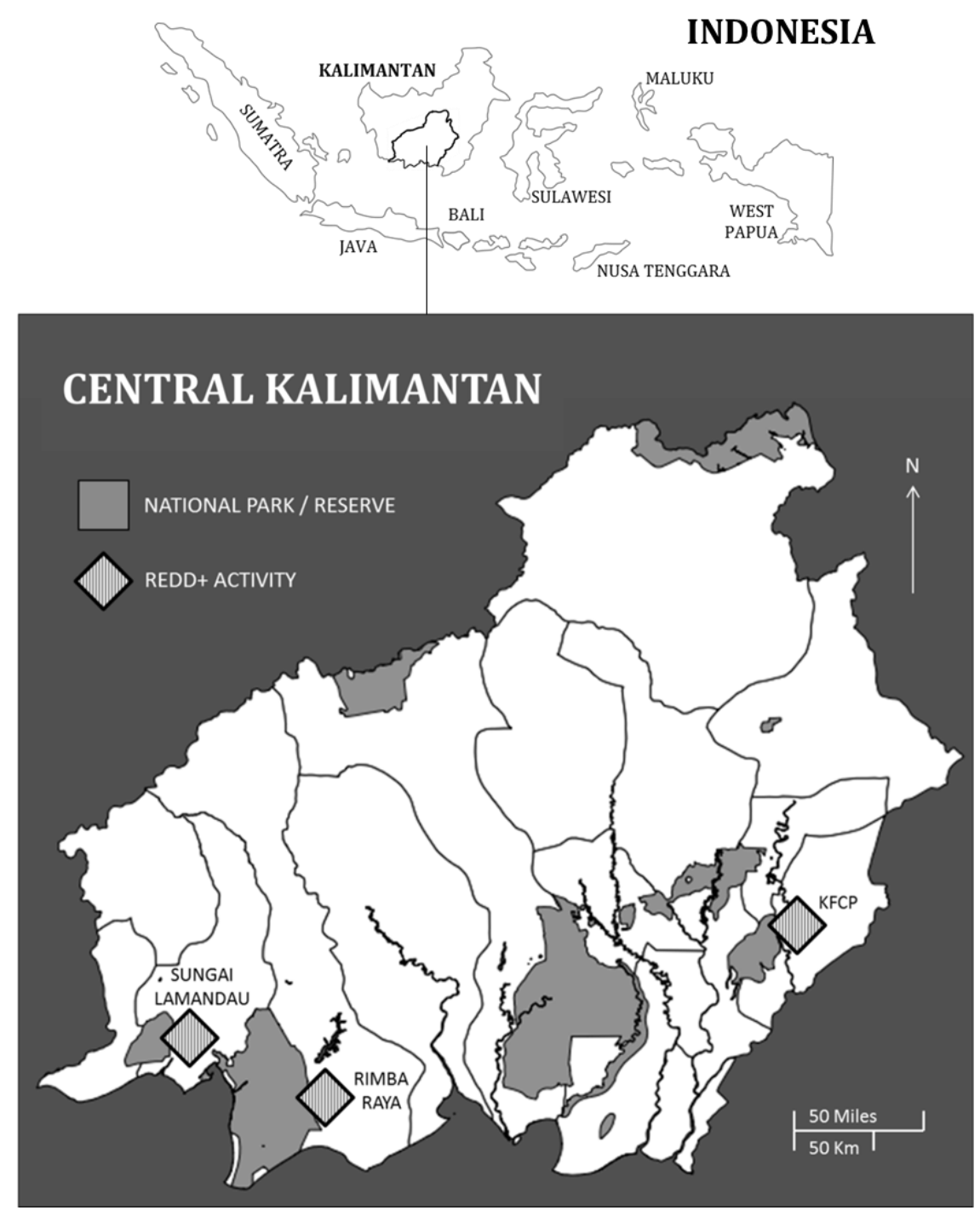

The province of Central Kalimantan was chosen to lead Indonesia's trials of REDD+. This is due to its high forest land cover ( seventy per cent, thirty-six per cent of which is classified as Hutan Produksi, or 'production forest') ${ }^{8}$ and high rates of deforestation. Among Indonesia's islands, the highest forest loss has occurred in Kalimantan $(\sim 3.2$ Mha; $\sim 65.7 \%$ ) (see Figure 2.3c). The largest forest loss in Kalimantan has occurred due to expanding oil palm plantations $(\sim 1.1$ Mha out of $\sim 4.8$ Mha or $\sim 22.8 \%$ of total forest

\footnotetext{
8 'Production Forest' is a land-use planning classification enabling development proposals for extractive industry and agricultural uses.
} 
loss in Kalimantan), followed by mixed concessions ( 714,000 ha; 14.8\%), and logging concessions $(\sim 717,000$ ha; $\sim 14.9 \%)$.

Figure 2.2: Data showing forest loss across Indonesia's five most forested islands together with main land use threats - Adapted from Abood et al., $2015^{9}$
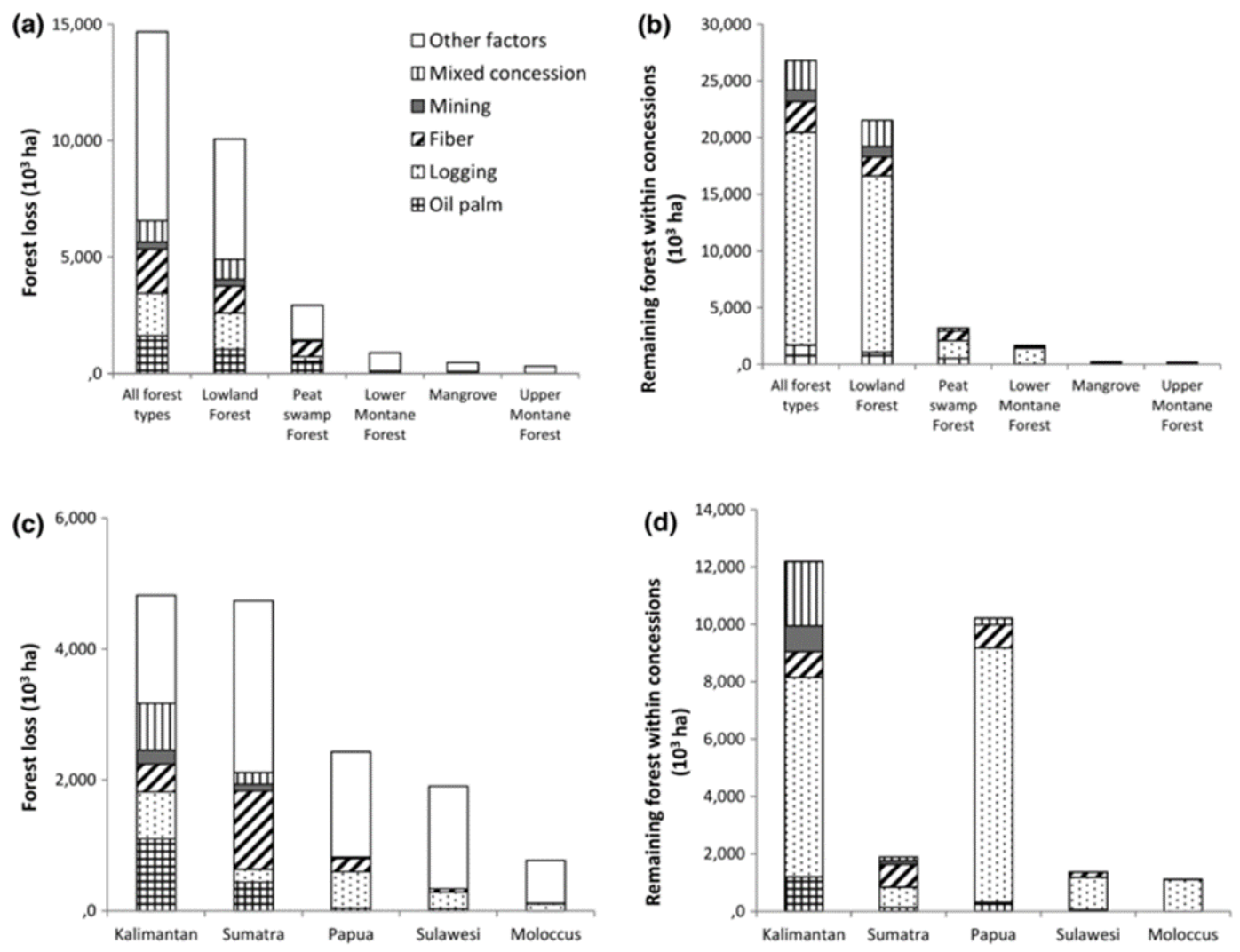

Existing research conducted within Central Kalimantan province has to date focused almost entirely on the four pilot districts included within the Government of Indonesia's (GoIs) SATGAS/STRADA activities for Central Kalimantan. Sungai Lamandau is the only REDD+ project in the province that falls outside of these districts. The site suffers the same ecological issues (i.e. high forest cover, high rate of deforestation, and unsustainable expansion of agriculture and mining sectors), making it attractive as a

\footnotetext{
${ }^{9}$ Abood et al. (2015) provide a useful overview of the relative contributions of the Logging, Fiber, Oil Palm, and Mining Industries to Forest Loss in Indonesia.
} 
pilot site, but its location means it has to date remained under-researched. It is also one of the only Community Forest (HKm)/REDD+ activities in the region. Furthermore, it is the largest proposed $\mathrm{HKm}$ project in Indonesia by far.

\subsection{CONTEXTUALISING REDD+ IN SUNGAI LAMANDAU}

\subsubsection{KOTAWARINGIN BARAT DISTRICT}

In 2010 an NGO consortium was established in Pangkalanbuun, with historic ties to a local orangutan charity, Yayorin. The consortium, in partnership with the Kotarwaringin Barat (KoBar) district government established a buffer zone on the boundaries of the Sungai Lamandau wildlife reserve as a potential REDD+ project site (for forest protection and restoration), to be funded through the sale of carbon credits (RARE, 2011).

The project aimed to formalise existing community groups, which Yayorin had facilitated since the charity's inauguration in 1991. To become a member of a newly formalised REDD+ community group, one had to possess a livelihood connection, and be a registered citizen of KoBar district. The REDD+ activity (the means by which carbon was to be 'produced' as a tradable commodity), involved the reforestation of the previously logged-over buffer zone using jelutung, a native rubber species. Rubber tappers were therefore encouraged to join one of the project's rubber tapping groups. However, the required 'livelihood connection' was different for each registered community group (Joshi et al., 2010). For example, one could participate in the REDD+ project as a rice farmer by joining a registered rice farmers group, even though rice farming was not an 
official REDD+ project activity. The reasoning behind this will be explained in later chapters.

In March 2011, ten groups, with members from villages across the district, formed a legally-recognised union known as Pelangi KoBar Bersatu - The United Rainbow of Kotawaringin Barat (or PKB). The union, on multiple occasions, formally submitted applications to the Bupati's office (local elected district Regent) for a Community Forest (HKm) licence, which would grant the union rights to manage the buffer-zone for carbon capture and restoration purposes. To date a decision has not been issued. However, assuming the licence would be awarded in the future, potential payments for carbon credits were to be allocated to each group member, regardless of their livelihood. Rice farmers would therefore receive shares of future carbon payments, as would jelutung rubber tappers, despite the fact that rice would produce no measurable additionality within the context of this REDD+ project $^{10}$ (see Figure 2.3).

10 'REDD rice' (carbon trading of rice-based emmisions off-sets) has been trialed elsewhere against considerable international resistance (see for example http://no-redd.com/no-redd-rice-manifesto-nowto-no-redd-no-to-using-rice-for-carbon-markets-2/) 
Figure 2.3: Map of Kotawaringin Barat district (Source: Author)

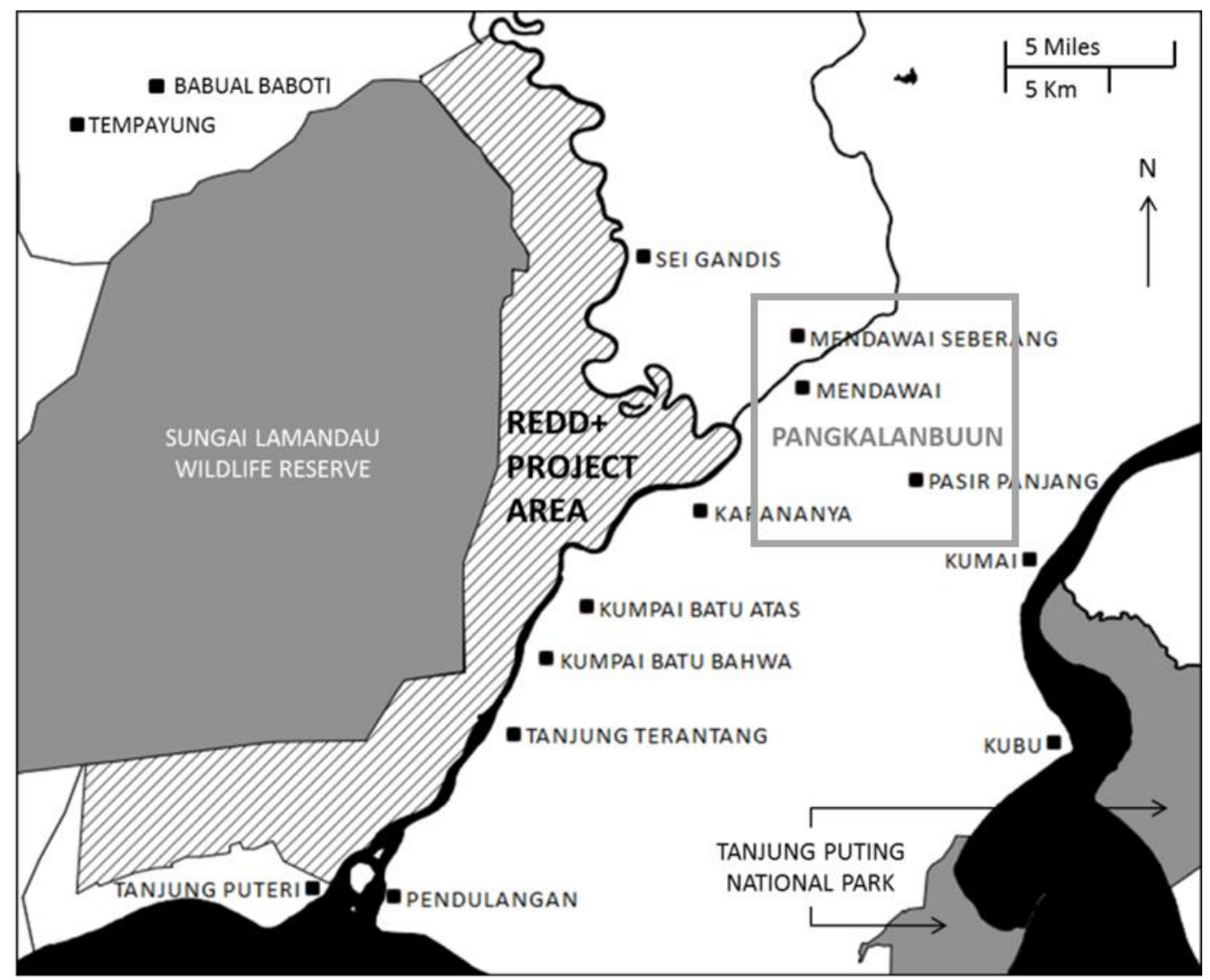

The Sungai Lamandau demonstration activity is the only REDD+ project in Indonesia where a community cooperative is listed by the carbon credit certification bodies ${ }^{11}$ as the project's official proponent. But, like most REDD+ projects, it has been influenced by a diverse array of actors and institutions, including: the World Agroforestry Centre (ICRAF); RARE; Orangutan Foundation UK (OFUK); Yayorin; CCI; and the union's multiple cooperatives. The REDD+ implementing consortium therefore constituted a unique and complex assemblage of interests, including: funders, corporate partners, government and non-government civil society groups (see Figure 2.4).

11 Verified Carbon Standard (VCS) and CCBA's Climate Community \& Biodiversity Standard. 
Figure 2.4: The REDD+ project actors of Sungai Lamandau

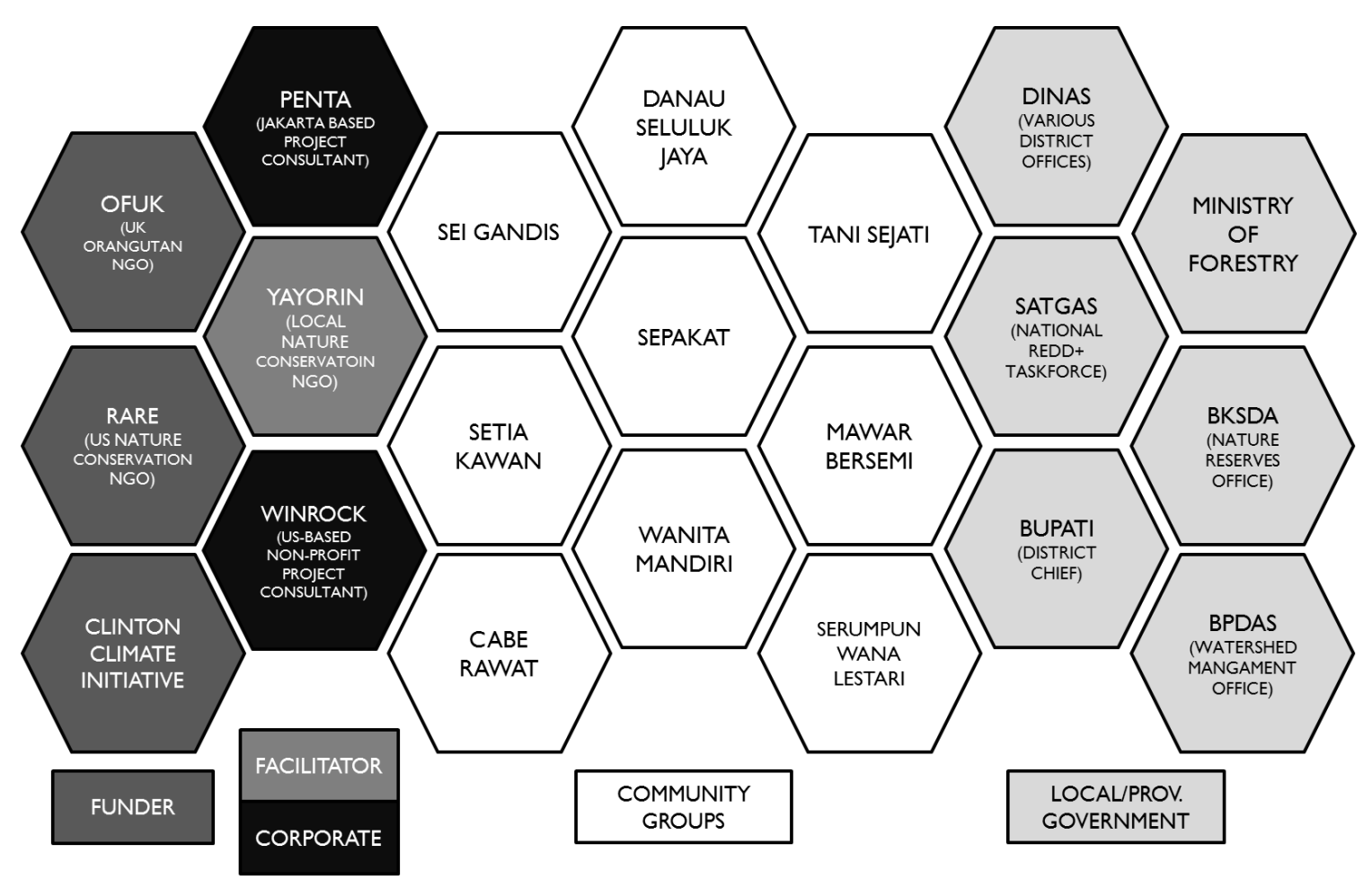

Despite the fact that KoBar district was originally formed as a Dayak ${ }^{12}$ administrative territory (van Klinken, 2008), the district is now dominated by indigenous Muslims (known generically in the literature as 'Malays'). Far fewer Dayak (8.5 per cent) populate the western districts of the Central Kalimantan province - Kotawaringin Barat, Kotawaringin Timur, Sukamara, Seruyan, and Kabupaten Lamandau, compared to the rest of the Province (BPS, 2012).

\footnotetext{
12 The Dayak are a grouping of indigenous peoples of Kalimantan. It is a loose term for over 200 riverine and hill-dwelling ethnic subgroups, located principally in the interior of the island.
} 
Much of my ethnographic research involved three distinct ethnic groups within KoBar. These included: i); Javanese transmigrants, relocated to settlements between Kumpai Batu Atas and Tanjung Terantang; ii) the Banjarese jelutung rubber tapping communities of Sei Gandis, Kumai and Kubu; and iii) the Mendawai of Pendulangan and Tanjung Puteri - a group of indigenous converts to Islam, influenced heavily by the Banjar Kuala people of South Kalimantan (see Table 2.1). I discuss the particularities of these communities in the section that follows.

Table 2.1: Villages (north to south), their main livelihood activities and ethnicities

\begin{tabular}{llll} 
VILLAGE & SUB-VILLAGES & MAIN LIVELIHOOD ACTIVITIES & MAIN RELIGION / \\
& & & ETHNICITY \\
\hline Tempayung & Tempayung - RT1 & Oil Palm \& plantation services & Dayak \\
& Babual Baboti & Oil Palm \& plantation services & Dayak / Muslim \\
\hline Mendawai Seb & Sei Gandis & Rubber tapping \& cattle & Muslim / Mendawai \\
\hline \multirow{2}{*}{ Mendawai } & Karananya & Market gardening \& tree nursery & Muslim / Mendawai \\
& Mendawai - RT23 & Market gardening \& tree nursery & Muslim / Mendawai \\
\hline \multirow{2}{*}{ Kumai } & Kumai & Rubber tapping \& cattle & Muslim / Banjarese \\
& Kubu & Rubber tapping & Muslim / Banjarese \\
& Tanjung Terantang & Rice and fish farming & Muslim / Javanese \\
& Kumpai Batu Atas & Rice and fish farming & Muslim / Javanese \\
& Kumpai Batu Bawa & Rice and fish farming & Muslim / Javanese
\end{tabular}




\section{BAHWA VILLAGES}

Following the concessioning of Sungai Lamandau's forests, most of the district's land area became classified as 'Production Forest' (or Hutan Produksi) for the extraction of hardwoods, like jelutung and teak. These land concessions' modestly increasing labour demands had been satisfied by expanding the pre-existing colonial government's transmigration programme. By the mid-1980s this was the world's largest ever statesponsored voluntary migration project (Whitten, 1987). In its modern version it aimed to move people from degraded or densely populated land on Java and some adjacent islands to the 'outer islands'. Within this programme, the transmigrant village of Terantang was established in 1987 as a rice production centre. Many of the Terantang transmigrants were neither fully aware of the tasks and hardships that awaited them, nor well equipped to deal with them. Their expertise in Javanese wet rice cultivation was of little help in the entirely different conditions of KoBar, with its acidic soils and frequent salt-water inundation from the Kotawaringin estuary.

In addition to assisting the transmigrants with land (roughly a two hectare plot per family), basic houses, and support to start their lives in a new place, the programme was also intended to assist populations in the receiving areas: The new infrastructure associated with transmigration, it was thought, would stimulate regional development and attract spontaneous migrants and investors; and the local population would learn from the transmigrants' "superior diligence and more advanced farming techniques" (Li, 2007: 81). Instead, the programme caused animosity between resident villagers, many of whom lacked the tenure security granted to transmigrants. The hardships also caused 
many transmigrants to displace local workers as they sought alternative employment within timber and palm oil concessions.

With their transmigrant labour force, the rapidly expanding oil palm plantations required large-scale canalisation projects of peatlands, exacerbating soil and riverine acidification. Furthermore, as owners of Production Forest concessions in Sungai Lamandau were licenced to remove the jelutung trees - a valuable hardwood transmigrant labour was blamed for exacerbating threats to the livelihoods of jelutung rubber tappers.

Settlements were formed as part of the transmigration programme between Terantang and the urban centre of Pangkalanbuun. The villages of Kumpai Batu Bahwa (Lower Rock of Kumpai) and Kumpai Batu Atas (Upper Rock of Kumpai) were established as distinct administrations in 1990. The two villages had a population mostly made up of landless labourers from Java as well as migrants from West Kalimantan. Most worked as casual rice farmers and labourers on karet rubber plantations. Many also worked in Pangkalanbuun or seasonally on oil palm plantations, logging concessions or in the nickel, gold and coal mines of the interior.

Residents of Tanjung Terantang, Kumpai Batu Atas and Kumpai Batu Bahwa had started welcoming development interventions from Yayorin, OFI and OFUK following the closure of Pangkalanbuun's two largest timber mills, which employed many of the village's transmigrants throughout the 1980s and 90s. Interventions included 'sustainable alternative livelihood' (mata pencarharian berkelanjutan) projects - fish pond construction and rice farmers' cooperative group facilitation. These co-ops would later function as REDD+ farmers groups within the Yayorin PKB umbrella organisation. 


\subsubsection{SEI GANDIS, KUMAI AND KUBU VILLAGES}

Perhaps the largest development/conservation intervention ever seen in Central Kalimantan involved the formation of the Tanjung Puting National Park in 1982, requiring the eviction of hundreds of Malay jelutung (native rubber) tappers, now living seasonally in Kumai and Kubu. Many moved into other concessioned areas of forest to find alternative sources of rubber. Their exclusion from the park, with little notice or compensation, aroused strong feelings for some, that 'fortress conservation' values (Brockington, 2002; Fletcher, 2010; Igoe, 2004) and the interests of societal elites were pursued at the expense of these communities' livelihoods. Three logging concessions which sat twelve-kilometres opposite Tanjung Puting, had soaked up much of the labour displaced from the Park's formation. These heavily logged-over concessions were then acquired by a consortium of international conservation organisations (including Yayorin and OFUK) in 1999, and combined to form the Sungai Lamandau Wildlife Reserve. Many casual loggers, 'illegal' gold miners and jelutung rubber tappers continued to be forcibly removed from the reserve through armed police operations (PolHut, 2009).

Kumai and Kubu function as the main deep water ports servicing Kotawaringin Barat from Surabaya and Semarang, on the island of Java. Kumai is also the main departure point for most tourists visiting the National Park. Several Javanese kelotok (tour boat) companies are registered in Kumai, collecting most of the 8,000 tourists who come to the Park each year (Turtle, 2012). These tourists are usually collected from the airport in Pangkalanbuun, before being ferried to eco-lodges or tour boats moored along the Sekonyer River, within the national park. Most of Kumai and Kubu's population identify as Banjarese. The Banjar people originated from South Kalimantan (Heryanto, 2006), but 
like other Malay groups, they have adopted Islamic traditions while maintaining their own distinct language - Bahasa Banjar.

Despite the significant distance between the coastal villages of Kumai and Kubu and the interior settlement of Sei Gandis, the rubber tapping community living on the northern banks of the Lamandau River all maintain homes in Kumai or Kubu as well. The group rears cattle within the REDD+ project site and also uses the forests for collecting jelutung rubber and rattan. With Yayorin's intervention, Sei Gandis formed a registered farmer's cooperative in 2011 with the aim of benefiting from REDD+ project activities.

\subsubsection{TANJUNG PUTERI \& PENDULANGAN VILLAGES}

Pendulangan is also home to jelutung rubber tapper groups who maintain their livelihoods from the rubber trees within the REDD+ project site and Lamandau Reserve. Most Pendulangan residents formally resided on the opposite side of the river in the now much smaller settlement of Tanjung Puteri. Due to frequent flooding Tanjung Puteri was abandoned by most villagers in two waves in 1992 and 1998, though around thirty house-holds still remain (BPS, 2011). As the village sits inside the protected Sungai Lamandau reserve, residents are required to hold a SEMAKSI (entry permit). This places severe restrictions on residents' mobilities and that of their guests.

Tanjung Puteri sits at an important junction to the Kotawaringin river and its Bulu tributary (Sungai Bulu). The tributary was once the main channel used by logging vessels to extract large hard-wood trees before the timber processing centres closed. It is now the main access route to the forest's rubber trees. Unlike the saline river water from the 
Kotawaringin and Arut, which are inundated daily from the estuary, the waters of the Bulu River are potable and maintain significant fish stocks.

Like Tanjung Puteri, the population of Pendulangan is predominantly Kalimantan Malay. Most speak Bahasa Mendawai for daily use and 'unofficial' speech. The Mendawai people are one of the most prevalent ethnic groups in Kotawaringin Barat (BPS, 2011). Many senior public officials, including the Bupati and local members of the People's Representative Council (DPR), identify themselves as Mendawai. It is also worth noting that all of Yayorin's local volunteer staff identify themselves as Mendawai Muslims. Yayorin's programme managers originate from West Java. Other ethnic groups, such as the Banjarese, Dayak and Christians are unrepresented within Yayorin's staff or contingent of volunteers. The significance of this ethnic mix is explored further in Chapter five.

Three registered farmers' cooperatives are located in Pendulangan, two of which were established following Yayorin's outreach work in 2010-11. These two groups - one male-only and one female-only - joined under the REDD+ umbrella group, PKB. These groupings split on the bases of various externally observable differences - gender, location, ethnicity and livelihood practices - disguise complex social relations, which require examination. 


\section{$2.4 \quad$ CONCLUSIONS}

Despite the growing enthusiasm concerning market-based conservation mechanisms like REDD+, their efficacy in many cases remains questionable. A growing body of research demonstrates that such mechanisms in fact commonly fail to perform as intended (Cavanagh \& Benjaminsen, 2014; Bock, 2014; McAfee, 2015). Critiques of REDD+ have also raised alarms about the effects of markets on rural livelihoods and people's rights and about the potential for REDD+ to facilitate the recentralisation of resource and territorial control by states (Phelps et al., 2010; Nel, 2014). Other critics of carbon-offset trading contend that the reasoning used in support of market-based environmental governance is misleading and internally inconsistent (Lohmann 2009; McAfee 2015). The collapse of carbon markets also casts additional doubts on their potential. The green-economy strategy both promotes and depends upon economic growth. So does REDD+, at least insofar as it depends on market-based financing, as the World Bank and private-sector REDD+ advocates prefer (CMIA, 2013).

Yet, REDD+, as an international framework, is multifarious, protean and complex. Its application in Sungai Lamandau offers a unique array of challenges and an equally unique set of possibilities for learning. This chapter has provided a background context to the on-the-ground complexities, which are explored in detail throughout the chapters that follow. I have also touched upon the connections between the embedded politics of place within the study site, which in turn have broader implications for an international green economy. The following chapter proposes a novel approach to explore these connections for understanding REDD+ in Sungai Lamandau. 



\section{CHAPTER $\mid$ TOWARDS AN INTIMACY THREE GEOPOLITICS OF REDD+}

\subsection{INTRODUCTION}

Climate change has introduced a new pivotal point in human development (Streck \& Terhalle, 2013). Consequently, according to Streck \& Terhalle (2013), environmental governance and, more specifically, climate governance has become the matter of 'geopolitics' in the 21st century. The increasing competition for resources (land, food, and fuel) associated with unprecedented warming and landuse changes has profoundly changed the context of international environmental governance. Figueres (2013) suggests that climate change amplifies every crisis humankind faces, including population growth, decreased water quality, food scarcity, and energy insecurity. The resulting need to impose limitations on the emissions of greenhouse gases and provide for adaptation strategies raises a multitude of political questions with a severe impact on the design and architecture of international agreements.

Climate change has also become a major new frontier for value creation and capitalist accumulation (Sullivan, 2012). Referred to by terms such as 'market environmentalism', 'green neoliberalism' and the 'green economy', the understanding is that if markets could just price the environment correctly - creating new 'environmental products' 
based on monetised measures of environmental health and degradation - then everyone and the environment will win.

Many scholars theorising market-environmentalist rationalities within solutions to climate change have agreed that such solutions cannot be understood in classical Marxist terms - they are not primarily driven by the urban proletariat, and they have emerged in response to an extraordinary diversity of economic and social dislocations (Levien \& Paret, 2012). Searching for new foundations, many have begun to resurrect Polanyi's (1944) theory of the 'double-movement' (Harvey, 2005; Levien, 2007; Holmes, 2013). Polanyi is useful because he brings to light the savagery characteristic (Springer, 2008) of market rationalities within solutions to climate change. The 'doublemovement' has also regained currency in recent years to explain the global growth of contemporary resistances to neoliberal environmental management (Evans, 2008).

However, the logics of markets and of social protection have come to manifest themselves in a far more complex and diverse array of configurations than the fairly neat economy-society, market-political authority split that Polanyi examined. This is especially so within REDD+ activities. The multiplicity, fuzziness and the diverse subjectivities REDD+ attracts and creates are making a coherent opposition to it difficult to articulate. Therefore, this chapter proposes an alternative to Polanyi's 'doublemovement' for understanding the social and environmental protection motives within a market-based REDD+ governance regime. I suggest that the central opposition which a 'counter-movement' depicts - between economy and society as reflected in processes of marketisation and social protection - presents itself in such a way that the problems emanating from the opposition can only be solved through its transcendence. The conceptualisation used here therefore proposes a critical feminist lens which allows for 
a more nuanced analysis of the performative agency of local people in shaping REDD+ in specific locales.

The suggested frame attempts to relocate the geopolitical subject from the grand global capital formations, like those imagined by Polanyi, and his ideas for regulating equitable benefit distributions, towards ordinary bodies - people's lives, and their unique histories. This approach attempts to highlight the utility of an intimacy-geopolitics (Pain \& Staeheli, 2014) for gaining analytical clarity, for thinking through and enacting positive (and perhaps radical) social change. In doing so, it seeks to connect seemingly disparate people, places, events, and issues to show the connections across various operations of power and productions of inequality and exploitation. It demonstrates the ways in which an intimacy-geopolitics challenges the overly rigid scales of REDD+ negotiations (from global to sub-national implementation - see for example Angelson et al., 2012) and refocuses attention on the seemingly apolitical, 'mundane', everyday reproductions of geopolitical power. It then suggests how an intimacy-geopolitics lens can help scholars understand the ways REDD+ manifests in places; to recognise how space and power are differentially experienced and embodied without assisting in the reification of hierarchal social structures. REDD+ projects are multifarious, spanning a range of sites and institutional forms. The conceptual framework used here attempts to illustrate the entanglements and indivisibility of proximate and distant spaces within REDD+ benefit sharing arrangements to show how people actively engage within the Sungai Lamandau REDD+ project.

Firstly however, it is useful to summarise the theoretical complexities of rendering forests "more valuable standing than cut down" (Katerere, 2010: 105). I will also 
discuss how doing so inevitably leads to exclusive regimes of access to forests in the production of associated carbon commodities.

\subsection{SELLING NATURE TO SAVE IT?}

Fletcher (2012) suggests that the growing effort to address anthropogenic climate change through market mechanisms, like REDD+, constitutes a form of disaster capitalism. Within this formation, neoliberal policies are used to manage crises as opportunities for continued economic expansion. Though I agree with Fletcher, there are two elements to this reading of disaster capitalism that I seek to trouble in relation to REDD+.

Firstly, the disaster discourses behind the politics of climate change do not generally warrant the "policy tsunamis" otherwise known as "economic shock therapy - the whole corporatist programme of privatisation, deregulation, cuts to government spending in the aftermath of a crisis" (Klein \& Smith, 2008:582). Climate change and deforestation stands somewhat distinct from the majority of crises Klein (2008) includes in her analysis, which are concrete, short-term, and relatively localised phenomena, whose impacts are immediate and easily linked with their cause. By contrast, changes to the global climate are characterised by great uncertainty concerning both their repercussions and the timeline over which they occur (IPCC, 2007). Moreover, most of the serious consequences that do occur will likely be cumulative; unfolding incrementally over substantial periods of time, and it may be difficult to directly link localised impacts with such a diffuse, global source. 
Secondly, the climate crisis was caused less by neoliberal processes per se than by an industrial capitalism grounded in fossil fuel exploitation and land use change. Market environmentalism serves as an attempted corrective, endeavouring in some cases to internalise environmental 'externalities' in what O'Connor (1994) calls capitalism's 'ecological phase' (see also Brockington et al., 2008). The 'disaster' of climate change however, does not require resolution to enable the production of profit.

In order to generate revenue through the exchange of forest carbon, reductions must be turned into tradable commodities (Bumpus \& Liverman, 2008). Offsets must be commodified into saleable units through the development of specific emission reduction projects, the outputs of which can be quantified, owned and traded (Beymer-Farris \& Bassett, 2012). Through this process, complex forest ecosystems are simplified into discrete processes and objects in order to define, standardise, and universally agree on their carbon content (Boyd, 2009). In the process, a 'fictitious commodity' (Polyani, 1944) is created in the form of 'carbon credits' (or Certified Emmisions Reductions CERs). In the course of "selling nature to save it" (McAfee, 1999: 133), elite political and economic actors wield considerable power in negotiating prices and regulating market participation (Liverman, 2004). Within these projects of rendering carbon saleable, access to simplified forest ecosystems, which constitute the sites of carbon commodity production, are made, by nessesity, exclusive.

Exclusion, as it is framed in this thesis, draws upon Hall et al.'s (2011:7) definition as, "the ways in which people are prevented from benefiting from things". This is a reversal of Ribot \& Peluso's (2003:153) Theory of Access definition as used in Chapter Four - "the ability to benefit from things". These conceptualisations of access and exclusion are explored further in Chapters five and six respectively. By combining both access and 
exclusion heuristics the thesis answers Myers' (2012) call to apply the concepts of possession and access control to Hall et al.'s (2011) Powers of Exclusion analytic to enrich it and explicitly show how different types of social relations affect, or are affected by, the powers of exclusion.

An oppositional politics to the sometimes violent exclusionary affects of markets, in which market contradiction can be resolved with finality through social protections, is unlikely to work (Holmes, 2013). A post-structural perspective of REDD+ offers a way to move beyond the restrictive binary conditions, put forward by thinkers such as Polanyi, which prevent a solution being reached.

The following section reflects upon Polanyi's notion of a 'double-movement', before suggesting an alternative analytical course. Rather than seeking the necessary 'solution' to the double-movement contradiction, or debating the extent to which that contradiction must or must not result in crisis, a post-structural feminist perspective of the double-movement instead allows for an exploration of how those contradictions are stabilised (or not) discursively.

\subsection{THE GREAT CARBON TRANSFORMATION}

\subsubsection{DISEMBODIED MARKETS, SOCIAL PROTECTION AND THE DOUBLE-MOVEMENT}

Polanyi's The Great Transformation (1944) is lauded as a landmark work in political economy (Fraser, 2009). Despite Polanyi having wrongly announced the death of laissez-faire capitalism with the cataclysm of World War II, much of what he had to say 
about nineteenth-century international political and economic liberalism still strongly applies in the contemporary world of globalised environmentalism and the neoliberal governance of the green economy. The book has had an important contemporary influence on the so-called 'cultural turn' deconstructing and exploring the genealogy of ostensibly stable referents such as 'the economy' (Mitchell, 2002; 2008) and 'society' (Burawoy, 2003) as part of a critique of 'economism' and narrow materialism (Prudham, 2013).

Polanyi understood that market relations did not historically determine the economy, and that it was not possible to think of the economy as autonomous in relation to broader social structures, including structures of social meaning and authority. Polanyi wanted to understand how, historically, the economy became separated from broader social and symbolic processes of meaning, that is, how something called the 'economy' came to appear as an autonomous system.

He distinguishes two different relationships between 'markets' and 'society': i) markets can be 'embedded' - enmeshed in non-economic institutions and subject to noneconomic norms, such as a 'fair price' or a 'living wage'; and ii) markets can be 'disembedded' - freed from the extra-economic controls and governed by supply and demand. According to Polanyi, the first possibility represents the historical norm. Throughout most of history and across disparate geographical contexts, markets have been governed by non-economic norms. These market controls limited what could be bought, by whom and on what terms. The second possibility, Polanyi argued, was a unique theoretical invention, the deployment of which threatened to utterly annihilate the underlying fabric of human society. Polanyi maintained that this disembedded market relation could never be fully realised as markets are only able to function 
against a non-economic background of cultural understandings and shared interests. Far from enhancing social cooperation through exchange relations, the disembedded market inevitably triggers social and environmental crises. He suggested:

A self-regulating market demands nothing less than the institutional separation of society into an economic and a political sphere. It might be argued that the separateness of the two spheres obtains in every type of society at all times. Such an inference, however, would be based upon a fallacy. Normally, the economic order is merely a function of the social order. Neither under tribal nor under feudal nor under mercantile conditions was there a separate economic system in society. Nineteenthcentury society, in which economic activity was isolated and imputed to a distinctive economic motive, was a singular departure (1944: 74).

To allow 'fictitious commodities' of land, labour and money to flourish without restraint would, in Polanyi's view, result in societal breakdown. Robbed of the protective covering of cultural institutions, human beings would perish from the effects of social exposure; they would die as the victims of acute social dislocation through vice, perversion, crime and starvation. Nature would be reduced to its elements, neighbourhoods and landscapes defiled, rivers polluted, military safety jeopardised, the power to produce food and raw materials destroyed; and, finally, shortages and surfeits of money would prove as disastrous to business as floods and droughts in primitive society. No society, Polanyi concluded, could stand the effects of "such a system of crude fictions even for the shortest stretch of time unless its human and natural substance as well as its business organisation was protected against the ravages of this satanic mill" (in Harvey, 2013: 175). 
For Polanyi, the crisis not only encompassed commercial interests seeking to disembed markets but also the counter-efforts of labourers, landowners and other strata to prevent it, to protect 'society' from the 'economy'. This struggle he referred to as 'the double-movement'. The first exposing movement implies danger, the second connotes safe haven (Fraser, 2013). Embedded markets are thus associated with social protection, while disembedded markets are associated with exposure and being left to swim naked "in the icy waters of egotistical calculation" (Marx \& Engels, 1888 [1992]: 6).

The distinction between embedded and disembedded markets has much to offer to a feminist inspired intimacy-geopolitics analytic. It points beyond technical economism and the functionalism of crisis as an objective system breakdown (Harvey, 2013). Furthermore, it can help towards a greater understanding of the workings within an intersubjective process which includes the responses of social actors to perceived shifts in their situation and to one another (Fraser, 2012).

\subsubsection{PRODUCING PROFIT FROM SOCIAL PROTECTIONS}

Creating a market for REDD+ forest carbon presupposes four critical elements: the existence of i) a quantifiable commodity or service, ii) buyers, iii) sellers and, iv) a marketplace with associated rules and regulations. These elements are not yet in place in Indonesia (Corbera, 2012). The commodity is hard to quantify, the sellers are not well defined, the big buyers do not exist and the rules of the game are not well established (Angelson et al., 2012). Designing and implementing a system that directly rewards emissions reductions (and removals), therefore remains a major hurdle. REDD+ also has 
ideological opposition. Building on a tradition going back to Polanyi, REDD+ has been criticised as "an example of the increasing privatisation and marketing of nature" (Lohmann 2012: 85). For some, REDD+ represents a system of 'capitalism in the forest,' (McAfee, 2015) with the potential for elites to define carbon rights and benefit sharing arrangements.

To understand this configuration one needs to entertain the logics of markets and social protections. These logics have come to manifest themselves in a far more complex and diverse array of arrangements than the fairly neat economy-society, market-political authority split that Polanyi examined. States sometimes behave using market logics; market actors sometimes exhibit state-like qualities, sometimes in contradictory and sometimes in supportive fashion. REDD+ is both a form of state regulation and a potential market mechanism - a source of capital expansion. REDD+ incorporates what Žižek calls a 'cultural surplus', whereby the pursuit of private profit incorporates a critique of alienated consumption (Žižek, 2014). The guilt incited by capitalist reproduction is sold with an assured absolution from the structural violence that such a mode perpetuates. The driver appears through the post-political illusion that 'there is no alternative' to liberal democracy and free-market capitalism (Žižek, 2011).

When meanings associated with social justice become understood only through an economistic lens, using mechnisms such as 'informed consent' (see Corbera \& Schroeder, 2011); where equity becomes 'benefit-sharing' (see Di Gregorio et al., 2013); where nature becomes 'natural capital' (see Juniper, 2012) and social protection is understood through a collection of 'safe-guards' (see Jagger et al., 2009), the results reify an economistic reality. REDD+, as a set of discursive and non-discursive practices and institutions, re-constitute the idea of a forest carbon market as an existing and 
autonomous reality. As Lakoff (1986: 135) points out, you cannot win an argument unless you expound your own values and re-frame the issue around them. If you adopt the language and values of your opponents "you lose because you are reinforcing their frame". Costing nature and social protections demonstrates that nature possesses no inherent value; that nature and people are worthy of protection only when it performs services for $u s$; that it is replaceable.

Butler (2012:148) suggests, "errancy and failure can and do enter into the performative circuits that we find in economistic conceptualisations of things". As a result, when we recognise that it is these repeated and sometimes errant processes that constitute the market as 'existing' in its autonomy, it follows that if those processes become too errant, the very existence of those entities can be called into question. To say that there is no singular REDD+, for instance, is not to say that REDD+ no longer has an object; it only re-describes that field and affirms that how we describe the field has something to do with how the field finally looks and what we take it to be. As Callon (1998) has pointed out, economic theory contributes to the making of the sphere of economics and, in particular, economic theory can be understood as one of the processes that performatively brings about the market, or what Callon called the market presumption'.

In the place of a methodological assumption of something called 'the market economy' is a set of processes that works to fortify that very assumption, but also to call into question its pre-given ontological status as well as the supposition that it operates by causal necessity (Butler, 2012). There is therefore nothing radically new about a REDD+ maintained on discursive practices rooted in the already dominant geo-political 
formation. It is only the expansion of what already is - profit, and the refiguration of social and environmental protection.

\subsubsection{COMPLICATING COUNTER-MOVEMENTS}

It is surprising that the same set of binary oppositions, between economy and society and between market and state, retain such influence in dominant conceptualisations of REDD+, given the messy nature of its administration. The binary logic of Polanyi's counter-movement clearly requires complicating and taking on post-structuralist 'claws'.

Post-structuralism, draws upon the legacy of structuralism, as conceived by Saussure. Where Saussure understood words as referring to an ontologically pre-existent reality, post-structuralists emphasise instead the extent to which the meaning of words is defined in relation to the meaning of other words. Thus, post-structuralists contend that the discursive realm is not epiphenomenal as opposed to some pre-existent objective reality, but actually constitutive of all meaningful comprehension. Analysis must therefore centre on the 'différence' between signifiers (words, discourses, etc.) rather than on the signification (or mis-signification) of an ontologically distinct reality (Derrida, 1967a).

This question of différence is a thread that runs through post-structural analysis, leading to an emphasis upon how particular things are constructed in relation to one another. The seminal author in this respect is Derrida (1967a; 1967b; 1972), who mobilised a critical enquiry into the role of binary distinctions in linguistics and in Western thinking in general. According to Derrida, linguistic oppositions consist of a privileged essence 
(an 'inside') and an excluded or secondary term (an 'outside'), which is merely accidental or contingent. Contrary to the view that the outside simply threatens or undermines the purity of the inside, Derrida argues that if the outside is required for the definition of the inside, then it is just as necessary as the inside itself. Derrida applies the idea to oppositions such as that between mind and body, rationality and emotion, man and woman, but the profundity and generalisability of the idea is such that it underlies myriad applications.

Critiques of neo-liberal ideology generally, and REDD+ especially, tend to undercut themselves by relying on the opposition between state and market that sustains that neo-liberal ideology itself. So Polanyi's narrative runs, an already existing 'barbaric' capitalism must be 'civilized' via the reregulation and re-embedding of the economic within the political. Rather than affirming the market-state binary through critique, Lemke (2011) suggests that one might instead ask what role these dualisms play in constituting and stabilising liberal-capitalist societies. A post-structural perspective of REDD+ offers us a way to move beyond these questions and to reconstruct the notion of a double-movement in a different way. Rather than seeking the necessary 'solution' to the double-movement contradiction, or debating the extent to which that contradiction must or must not result in crisis (in essence, a similar question), a post-structural perspective might push one to ask instead how those contradictions are stabilised (or not) discursively.

What is at stake in these debates is the politics of the possible. Binary oppositions not only frame debates in a broad sense, but serve as moments of what Foucault (1969) called 'problematisation', which develop the conditions in which possible responses can be given. In other words, the specific form in which the problem is presented - state 
versus market, economy versus polity, capitalism versus democracy, and finance versus regulation - influences the conception of what kind of REDD+ is possible or impossible. As Foucault explained (1984:456), "it is a question of [trying] to see how the different solutions to a problem have been constructed; but also how these different solutions result from a specific form of problematisation".

A feminist economics problematisation offers some ways past the neo-liberal trap of classical economic analysis. Feminist economics, according to Barker (2005), is a knowledge project that works toward a feminist transformation of economics. Using gender as an analytical category, feminist economists have shown that unquestioned and unexamined masculinist values are deeply embedded in the theoretical and empirical aspects of classical economics (see for example Waring, 1988; Strassmann, 2008; Ferber \& Nelson, 2009). Such aspects rationalise and naturalise existing social hierarchies based on gender, race, class, and nation. Although this is especially true of issues particularly relevant to women's lives, such as the gender wage gap and the feminisation of poverty, it is no less true of issues in international trade or macroeconomics.

Although a feminist economics highlights the asymmetric effects of economic theories and policies that are hidden by conventional theorising, it still retains those same underlying visions of perfectibility in evidence in Polanyi's examples. As with Polanyi, a feminist economics suggests policy, and an outlook on life, in which contradiction and antagonism can be resolved with finality. Market-based violence becomes represented as a problem that must be solved, yet that solution is placed permanently out of reach by the very nature of the problematisation (Holmes, 2013). This process may be considered 'feminist', but the results of market-based policy interventions, I argue, will 
always be exclusive and competitive, enabling accumulation by a few, at other people's expense (see Harvey, 2005).

However, it is clear that feminist intellectual moves to transcend dualistic thinking lend traction to contemporary debates about resource depletion, environmental degradation, and environmental injustices 'on the ground'. Specifically, how transcending nature-society dualisms inform a normative political economy (Prudham, 2013). A critical-feminist reading of the 'double-movement' therefore might not only be post-structural and relieved of its binary constraints, but also turned to focus on what Fraser (2013) terms, 'the missing third'.

For Fraser, the double-movement would be more usefully conceived as a triple movement, one which recognises the domineering potential of social protections. Although Polanyi's ideas reflect a "commitment to replace capitalism with a socialist order" (Dale, 2010:22), Fraser suggests that this intervention inevitably serves to prevent the reconstruction of dominant hierarchies and exclusive access regimes, which subordinate women and other traditionally marginalised groups. 'Emancipation' - the enactment of a third protective movement - could circumvent this, and bring about a tolerable solution. A critical analysis of REDD+ should therefore be framed, so as to acknowledge the potential for violent and oppressive societal protections and entrenching of existing status hierarchies. This frame needs also to escape the dualistic representations which place imaginations within a discursive cul-de-sac of neoclassical market environmentalism. An intimacy-geopolitics, I suggest, offers one way to do this. 


\subsection{AN INTIMACY-GEOPOLITICS OF REDD+}

\subsubsection{RE-EMBEDDING CRITICAL ANALYSIS}

A feminist-inspired intimacy-geopolitics can offer REDD+ scholars some much needed analytical traction. Such an approach attempts to move the conversation beyond economistic objects of analysis and flesh-out what Hyndman (2001:210) calls a "feminist geopolitical imaginary" by complicating the understanding of key concepts such as violence, access and exclusion.

'Standard' geopolitical analysis of REDD+ has tended to divide global space into discrete territories and spheres of political-economic influence through which systems of regulation operate (see for example Maraseni \& Cadman, 2015). Rather than simply understanding the way in which nation-states, international REDD+ institutions, and other global powers interact, the geopolitics used in this thesis considers an alternative perspective.

Calls for a 'counter-geopolitics' (Secor, 2001), 'anti-geopolitics' (Routledge, 2003), 'subaltern geopolitics' (Sharp, 2009), 'emotional geopolitics' (Pain \& Smith, 2008; Pain, 2009), feminist geopolitics (Dowler \& Sharp, 2001; Hyndman, 2001, 2007; Secor 2001; Smith, 2001; Staeheli, 2001), and attention to the 'global intimate' (Mountz \& Hyndman, 2006; Pratt \& Rosner 2006) have been met by promising work ${ }^{13}$. Feminist geopolitics has developed as a distinct analytical, epistemological, and methodological approach in geography (Massaro \& Williams, 2013). This approach connects both the seemingly close-knit with seemingly disparate people, places, events, and issues. This shows the connections across various operations of power and productions of inequality. It also

${ }^{13}$ See Smith (2012) for a more comprehensive review of the movement. 
demonstrates the ways in which an intimate frame challenges the scales of geopolitics and refocuses on the potentially 'mundane', everyday reproductions of geopolitical power.

Seemingly non-geopolitical sites and concerns are key to the operation of 'global' power. The point of entry to such topics of study is often the less visible everyday lives of individuals (e.g. small-holders, labourers, migrants and children). Feminist scholarship in the field takes the approach of 'studying up'-“studying the powerful, their institutions, policies, and practices instead of focusing only on those whom the powerful govern" (Harding \& Norberg, 2005:2009). By studying up, researchers can understand the ways in which knowledge is produced and problems are conceptualised in ways that shape social relations in uneven and hierarchical ways. For example, Fluri (2011) and Hyndman's (1997) examinations of international development and humanitarian aid organisations sheds light on how efforts to 'assist' those in need function to (re)produce hierarchical power relations.

The aim here is to challenge dominant geopolitical narratives promoting global 'greengrowth' and the exclusions and inequality inherent in such supportive scholarship. Feminist geopolitics has established itself as a distinct branch of critical geopolitics by noting the need for a more grounded critique - one that includes women of course, but also goes beyond this and attends to the gendered, racialised, classed, sexualised, and otherwise differentiated everyday spaces previously ignored in geopolitical analysis. Such an approach acknowledges the shifting nature of intimacy as more than an issue of geographic locality.

The framework used here enables one to situate places in their broader context, to dismantle the global-intimate binary and examine the spatial temporality of actors and 
actions. My analysis of access and exclusion in Sungai Lamandau draws upon Pain and Staeheli's (2014) Intimacy-geopolitics and violence. They suggest that intimacy consists of three intersecting sets of relations, which work simultaneously rather than separately. Firstly, intimacy is understood as a set of spatial relations, stretching from proximate to distant. In this regard, my analysis, like much feminist research, emphasises the body as the primary unit of analysis. Secondly, intimacy is understood as a mode of interaction that stretches from personal to distant; for example, in Chapter seven I reflect on how emotions, fears and knowledges affect how subjects resist and shape wider power relations and formalised systems of REDD+ operation. Thirdly, intimacy involves a set of practices, again applying to, but also connecting the body and that which is distant; for instance, livelihood strategies in Sungai Lamandau often traversed the interpersonal, institutional and national realms.

Within this framing of intimacy-geopolitics, the geopolitical is exposed as already created by and consisting of relations and practices of intimacy: the already-thereness of the intimate as foundational to and within other realms (Pain \& Staeheli, 2014). In doing so, this framing attempts to uncover how intimacy is wrapped up in geopolitical processes of exclusion, so as to already be a fundamental part of them. This intimacygeopolitics actively resists the reification of hegemonic power relations, placeless geopolitics of domination and power-laden states by attending to 'ordinary' people and their 'alternative' REDD+ knowledges. The framing also privileges understandings of complexity, perspective and place-specific contexts over the economistic necessity to produce comparability in the name of a commensurable REDD+ product.

The goal is to rotate the usual framing of geopolitics, and to rethink it as variously configured relations, interactions and practices in particular places. These relations 
produced domination as well as resistance across all practices and sites of REDD+ implementation. Thought through an intimacy-geopolitics frame, these relations are constitutive of an 'everyday' double-movement, where access controls and marketbased violence are continually countered.

\subsubsection{CONNECTING INTIMATE BODIES: RE-SCALING REDD+}

The intimacy-geopolitics frame seeks to avoid discursive abstractions which serve to reinforce a fixed 'global scale' and placeless state power. Attention to traditional geopolitical discourse, even in the form of critique, perpetuates the removal of people and everyday practices from geopolitical analysis (Sharp, 2000). The intimacygeopolitics approach, as it is used here, challenges the nation-state as the sole or primary subject of geopolitical thinking by attending to the social construction of scale (Marston, 2000) and the interconnections among and across scales (Herod and Wright, 2002; Pratt and Rosner, 2006). For example, Hyndman $(2004,2008)$ suggests that our understanding of security (a classic theme of geopolitics) is fundamentally transformed if we begin questioning security at the scale of the individual body as opposed to that of the nation-state. A focus on human security, rather than national security, provides a way to attend to the lived realities of individuals as they are shaped by and influence geopolitical processes. Furthermore, a shift to the scale of the body enables an analysis of the way geopolitical processes are experienced unevenly across differently situated populations (Massaro \& Williams, 2013).

There is widespread attention within contemporary geography to the politics of scale, yet many scholarly projects investigating REDD+ continue to take scalar ontologies for 
granted (see for example Hoang et al., 2013). Scales are not pre-given entities. Rather, scale is socially constructed, and its meanings come into being through, and are productive of, socio-spatial hierarchies and processes (Silvey, 2004). In contrast to neoclassical approaches to REDD+ studies, this intimacy-geopolitics enquiry is centrally concerned to disentangle the politics of gender and difference as they shape both the knowledge that is produced about scale and the dynamics and meanings of scale in practice. Hyndman (2001), for example, argues that a critical analysis of dominant scale discourses allows investigation of the assumptions and power relations that are embedded in standard geopolitical views of scale, a project that "is important precisely because such assumptions define research questions, shape government policies, and generate common frames of reference" (Hyndman \& Walton-Roberts, 2000: 246). A feminist concern with the politics of scale allows for the conceptualisation of relational linkages between bodies, households and the transnational sphere (Nagar et al., 2002). Such a focus on the politics of scale does more than note the exclusion from REDD+ studies of particular scales, such as the body and the household, it develops understandings of these scales as integral to the analysis of REDD+ geopolitics.

For example, Smith's (2011) examination of the role that love and desire play in the geopolitics of territoriality in the Leh region of India illustrates how the most intimate aspects of daily life are shaped by and, in turn, shape geopolitical processes. Through this attention, intimacy-geopolitics makes the relationship between the intimate and the global evident. Smith shows how territorial struggles are not just about control over abstract state space or land based borders and boundaries but are, more viscerally, about control over the marked bodies that inhabit those spaces (Massaro \& Williams, 2013). This approach provides tools for seeing the processes in which power operates 
in similar ways across such disparate sites and scales. In so doing, an intimacygeopolitics ties distant places and problems together, drawing what Katz (2001: 1213) has referred to as "counter-topographical lines of analytical understanding and political possibility" across a wide range of places and populations.

\subsubsection{PUSHING BACK AGAINST GEOPOLITICAL ORDERING}

Despite the caring nature of an intimacy-geopolitics scalar ontology, there remains, as Harvey (2012: 69-70) contends, “an analytically difficult 'scale problem' at work that needs (but does not receive) careful evaluation". Marston et al. (2005; see also Jones et al., 2007) sought to advance a flat or site ontology by expunging scale from the geographical vocabulary. For them, the delusion of scale is that it represents a theoretical distraction, a drawing away from the grounded particularities of the everyday. As Springer (2013: 7) states:

When we 'jump scales' we engage in such distraction precisely because we lose our footing and relinquish our grip on our surroundings to soar off into an abstract sky, only to touch down on the immediate materiality of everyday life when and where it becomes convenient to our argument.

In contrast to the distraction of scale, a call for flattening is precisely about the materiality of the site; it offers a means of "sticking our wheels in the dirt and rocks of immanence" (ibid). Metaphors such as 'jumping scale' wrongfully impart a sense that politics should operate through vertical hierarchies, rather than around multiple sites of horizontal activity and autonomous resistance. Such an orientation forestalls the potential that exists within a flat ontology of immediacy wherein social structures, 
power relations, and hierarchies become identifiable, accessible, and ultimately transformable.

A scalar flattening does not mean that flows of affinity are severed and networks of cooperation not established. Geography still functions through space as the simultaneity of 'stories-so-far', and place as collections of these stories (Massey, 2005). What is new and different here is an acknowledgment and, when appropriate, the dismissal of the hierarchy that human geographers often assume is embedded within notions of territory, a spatial assumption that perpetuates the dominance of capitalism and market-based authority in society.

Yet, if it is the case that geopolitical thinking reproduces and maintains geopolitical orders and power relationships and it is also the case that intimacy-geopolitics forces a rescaling of our geopolitical imaginaries, why call this work geopolitical? Although we may need to consider reconfigured scales, nation-states and markets, the geo-political remains relevant as it still connects the everyday processes and situated positions, which often constitutes the feminist object of study. For an in-depth exploration of geographies of violence, exclusion and displacement, an intimacy-geopolitics allows for a focusing-in on the nuanced processes of dispossession, which a 'standard', masculinist geopolitics tends to disguise. A geopolitics which draws attention to the sudden 'outbreaks of violence' such as war, civil unrest etc. must change to stay relevant to the social world. As Puar (2007) explains, wars are no longer against enemy nations, so much as abstract conceptions of otherness. A feminist intimacy-geopolitics analysis enables an examination of precisely how otherness is produced through gendered, racialised, and sexualised discourses and then mobilized to justify various everyday forms of violence and oppression (Mountz, 2011). 
By exploring the intimacy-geopolitics of REDD+ I intend to draw attention to the seemingly 'apolitical' (or 'a-geopolitical') realms of the body, the home, and intimate relationships as key sites where geopolitical power is (re)produced and challenged. Rather than abandoning the geopolitical in activism and scholarship, an intimacygeopolitics highlights the hierarchies placed within the spatial register. That is to say, the world may maintain a geopolitical order, but human geographers must engage that ordering to reimagine it and argue for its reconfiguration.

\subsection{CONCLUSIONS}

'REDD+' is not a coherent picture, nor a lucid programme of action, nor an integrated institutional architecture. Marketisation of forests in the form of REDD+ carbon finance does not mean blanket and unfettered market expansion - a triumph of capital over state (Engels, 2006). It is a multifarious project spanning a range of sites and institutional forms. Each frontier of marketisation seeks to legitimise and socialise carbon market architectures, albeit with mixed results. REDD+ is not being made unwieldly by its complex assemblages. These assemblages are in fact what make REDD+ possible. Things green have become big business and an integral part of the mainstream growth economy.

In the twentieth century, the 'green movement' could be depended on as a critical voice and an antagonist with market forces, providing an effective counter-movement to the ravages of capitalist expansion and voracious economic growth. Today, this dependability is increasingly difficult to uphold. Whilst in the twentieth century, forest conservation agendas were implicated in the alienation of land and the regulation of 
land use by colonial and post-colonial regimes, this was often not with commercial intent (though it often had commercial effects) (MacKenzie 1988; Adams 2004). Now, it is explicitly so. If the green movement has transformed in this way, it is in response to this contradiction: it has stepped from the critical margins to hold centre stage in an advocacy of a new global green economy, firmly located in capitalist networks, and as part of a vision of 'ecological modernisation' where economic growth and environmental conservation work in tandem.

A lot of ground has already been made in detailing the relationships between private and public authority in climate governance. Less understood are the materialities of everyday life as they constitute the substantive foundations - the bodies, the subjectivities, the practices and discourses - of constantly unfolding intimate and geopolitical tensions and conflicts within the REDD+ arena. As well as providing a frame that does not insist on economistic roots, anchoring one in unproductive ground, the intimacy-geopolitics proposed here, encourages ideas of justice grounded in and between bodies.

Conceptualising REDD+ within a Polanyian configuration depends on ideas of economistic 'consideration' based on 'quid-pro-quo' market exchanges and theoretical contractual liabilities. Through an intimacy-geopolitics, REDD+ 'benefits' appear more as a matter of performative agency, rather than imposed patriarchal compensations. In such a framing, REDD+ 'Risks' appear as a personal challenge to ones dreams, rather than an 'opportunity cost' or unforeseen capital expense. The 'counter-movement' to market rationalities becomes an 'everyday' affair, linking actors and practices of accessing (and excluding others from) REDD+ benefits across various scales of implementation. 
Through an intimacy-geopolitics, critical scholars can draw attention to the dominant hierarchies; help shape how REDD+ evolves, pursuing models that are acceptable from social, environmental and economic perspectives. This approach offers a novel frame to engage with REDD+ which provides an opportunity to critically contest the programme's basic principles, while contributing to a more robust socially and environmentally appropriate future. To paraphrase Ferguson (2009), it is about engaging with grounded policy and practice in the compromised and reformist terrain of the possible, to repurpose and politicise managerial mechanisms in ways that contribute to a more just and equitable world (cited in McGregor, 2012).

The following chapter explains how the framing was utilised in practice. It describes the research methods used with subversive intent to explore the intimacy-geopolitics of access and exclusionary arrangements playing out in Sungai Lamandau. 



\section{$\underset{\text { FOUR }}{\text { CHAPTER }} \mid$ METHODOLOGY}

Each friend represents a world in us, a world possibly not born until they arrive, and it is only by this meeting that a new world is born.

Anaïs Nin (1966 - in Taylor, 2011: 3)

\subsection{INTRODUCTION}

Before I first packed my bags for Indonesia in early 2012, I got in touch with a number of returned Volunteer Services Overseas (VSO UK) volunteers, to get an idea of, and prepare for, life in rural Indonesia. One volunteer stated in an email:

you will meet lots of lovely genuine people. [...] They'll take you in and make you part of their community, even though you're a bule ${ }^{14}$ who speaks bad Bahasa. [...] You'll meet lots of people you can trust, but I doubt you'll call them friends (Mike, email - 23 February, 2012).

14 White foreigner, generally of European decent. 
This chapter explains how I managed relationships of trust, navigating commitments to doing ethical and accountable research while investigating (and hopefully, influencing) the high stakes arena of REDD+. In doing so I explain how qualitative, ethnographic methods were used in an effort to dismantle the customary divides between scales and sites of intimacy and geopolitics, and between myself as a researcher, an activist, and a potential friend to people within the Sungai Lamandau case study.

The main strength of this case study approach was depth. As Flyvbjerg asserts (2011: 314), "if you want to understand a phenomenon in any kind of thoroughness, you need to do case studies". Eysenck (1976: 9), who originally saw the case study as nothing more than a method of producing anecdotes, later realised "sometimes we simply have to keep our eyes open and look carefully at individual cases -not in the hope of proving anything, but rather in the hope of learning something".

As the Sungai Lamandau case study site was a remote and under-researched demonstration activity, it had not suffered from the research fatigue issues of other more high-profile sites of implementation in Indonesia. These high-profile projects included the Kalimantan Forest Carbon Partnership (KFCP) and the Rimba Raya carbon project, both extensively covered in the international news media. The Sungai Lamandau site was suffering threats from competing land-uses such as oil palm conversion and fast-wood plantations. The existing forest planning classification allowed for these conversions, and applications to local government officials had already been presented. The social and conflicting land use issues prevalent within Sungai Lamandau made the project an ideal opportunity to investigate my central research question - How do people actively engage within the Sungai Lamandau REDD+ project? 
Another important reason for researching REDD+ in Sungai Lamandau, was that at the time of commencing my doctoral candidature, REDD+ activities were starting there. On paper there were many on-going REDD+ projects in Indonesia, but unless people were engaging 'on the ground' then there would not be a lot to see. Furthermore, REDD+ was being produced when I arrived. I therefore had the opportunity to help shape it into something desirable.

REDD+ in Sungai Lamandau was not a thing, but rather a process. It could not easily be objectified outside of official reports. Its boundaries (beyond 'official' cartographies) were a collection of discursive categories. To say the REDD+ project was a peaty field with trees and birds, would be to suggest that REDD+ had always been there. It had not. REDD + for many people existed fleetingly, once a month perhaps - when a tall bule man, like me, stopped by for a chat. REDD+ rode away after a day or two's discussion, leaving behind forest-spaces - spaces which had always been there. I was not however, committed to an immutable vision for any one single REDD+, but rather to the participation of drowned-out voices in engendering visions for the future. My role as a scholar-activist was to pursue and engage with theoretical and conceptual questions in ways that were always dialectically rooted in the struggles of everyday life. A reflexive approach was therefore required which sought to account for the ways in which my various positionalities influenced the research process (Sultana, 2007).

In the following section I reflect on the methods used to gather material, adopting a feminist intimacy-geopolitics approach to interviews and observations. I reflect on how these methods were utilised, balancing commitments to rigorous scholarship, and activism to bring about more equitable outcomes. The third section explores how, throughout my research, REDD+ knowledges and claims to truth were co-created. I 
discuss the difficulties I had in accessing spaces of decision making, and opening them up to be more accessible for marginalised actors. In doing so I explore my own positionality within the context of knowledge production, examining how people came to understand REDD+ and how different knowledges, competed in decision making. The penultimate section considers how the material was analysed and 'written in' (Mansvelt \& Berg, 2010), before the chapter's conclusion.

Throughout I am concerned with the negotiations required of engaged and responsible feminist ethnographic research, using case-driven methods that worked to be decolonising (Smith, 1999), discussing what was more and less successful.

\subsection{USING CASE-DRIVEN METHODS}

\subsubsection{A FEMINIST ETHNOGRAPHY}

The empirical data drew on a combination of qualitative, ethnographic methods, placing me inside participants' homes, kitchens, fields, plantations and fishing boats. From these vantage points I was able to observe the range of performances which were enacted by women and men in relation to each other and their families and neighbours, as they utilised various props and intermediaries. I was also able to focus on intimate relationships that might otherwise be ignored, and to ask questions that might otherwise be overlooked.

My intimacy-geopolitics approach contrasted with the many occasions I had witnessed academic researchers, NGO workers and government officials arriving in speed boats with short questionnaires or to conduct structured interviews eliciting the same 
rehearsed responses. The need for a more nuanced approach was clear. I too had received such responses during my introductory explorations. Following one five-day trip up-river with a Mendawai rubber tapper named Hadiz, I was given a surprisingly frank explanation for one persons participation that I had not heard before: "the reason I take part in the REDD+ project activities is to have time on my own away from my family" (20 September, 2013). Motivations to participate in the project varied significantly depending on how much time I had spent with the respondent prior to eliciting any meaningful response.

The research methods were designed to privilege the informant - some wanted to be filmed and recorded for sound; others objected to me taking notes of any kind during our meetings, through fear of interrupting the conversation. These methods required fluency in written and spoken Bahasa Indonesia, which I had. In order to spend as much time as possible with each respondent, I would join them in whatever work they were doing. It may never be possible to fully establish the extent to which thier performances were 'staged' for my benefit, but my presence as an observer undoubtedly had an impact on what played out during my ethnographic observations.

Ethnography is a methodology that develops in practice and is best defined through a consideration of how it is practised (Pink, 2009). O'Reilly (2005:2) usefully defines ethnography as:

iterative-inductive research that evolves in design through the study, drawing on a family of methods, involving direct and sustained contact with human agents, within the context of their daily lives and cultures, watching what happens, listening to what is said, asking questions, and producing a richly written account that respects the irreducibility of 
human experience, that acknowledges the role of theory as well as the researcher's own role and that views humans as part object/part subject.

Throughout this inquiry, data collection and analysis reciprocally informed and shaped each other through an emergent iterative process (Charmaz, 2011). Undertaking research in this way involved a constant reflection on language and meaning, and how themes that emerged during the fieldwork spoke to wider processes, contexts and theories (Knigge \& Cope, 2006). New themes were incorporated as they grew in salience, while redundant avenues of inquiry, which were not generative or particularly important within that context, were abandoned.

Many feminist scholars have identified ethnographic methods as ideally suited to feminist research because its contextual, experiential approach to knowledge avoids the false dualisms of positivism (Stacey, 1988). Drawing upon traditionally feminine strengths as empathy and human concern, allowed for a more egalitarian, reciprocal relationship. However, there is also a great irony that ethnographic methods can subject research participants to a greater risk of exploitation, betrayal, and abandonment by the researcher than does much positivist research. Fieldwork and its textual products represent an intervention into a system of relationships that the researcher is far freer than the researched to leave. The rest of this section explains the multiple qualitative methods used as well as the strategies applied to overcome the risks placed on the research participants. 
Although I use the word 'interview', I want to stress that I was not the only one with questions relevant to the research. The questions asked by the participants were as important as their responses to mine, if not more so. They illuminated what to them were the salient issues requiring further exploration.

The first interview was conducted on $30^{\text {th }}$ April, 2013 at a UNFCCC event in the Peninsular Hotel, Central Jakarta. For the sake of courtesy, I arranged a meeting with the Sungai Lamandau project's principal donors - the forestry devision of CCI. I had arranged the meeting following introductions by Dr Andrew McGregor ${ }^{15}$. During his visit to Jakarta the CCI representatives had expressed an interest for me to focus my enquiries on the Sungai Lamandau project. It was agreed that my research findings, and my previous work experience, could prove mutually beneficial. I had experience working in the Indonesian forestry sector and had produced environmental reports. Over the course of the previous year I had been reading many REDD+ Project Design Documents (PDDs) for various projects across Indonesia. The Sungai Lamandau project implementers were also required to produce such a document.

I was invited to the REDD+ working group's (PKB) three-monthly meeting in Pangkalanbuun, Central Kalimantan a week later, where I introduced myself to the various leaders of Sungai Lamandau's farmer's groups. I began interviewing the farmer's groups' members soon after the PKB meeting and ultimately carried out 141 semi-structured interviews. Although focus groups did not form an explicit part of the research, not every interview was 'one-on-one'. Some started that way, but as friends,

\footnotetext{
${ }^{15} \mathrm{My} \mathrm{PhD} \mathrm{research} \mathrm{formed} \mathrm{part} \mathrm{of} \mathrm{a} \mathrm{wider} \mathrm{project} \mathrm{investigating} \mathrm{the} \mathrm{political} \mathrm{ecology} \mathrm{of} \mathrm{forest} \mathrm{protection}$ in Indonesia. More information on that project can be found here: http://www.royalsociety.org.nz/2015/02/09/yellow-light-for-forest-saving-programme-in-indonesia/
} 
neighbours and family members came to visit, many turned into impromptu group meetings. In these situations I was careful to understand the dynamic relationships between respondents before I prompted any new research questioning. On occasions such opportunities for conferring between group members was useful. It was very difficult eliciting information about a thing, when neither party knew exactly what the thing was. Many farmers and small-holders understood the REDD+ project as the $\mathrm{HKm}$ sama bonus (the community-based forest protection project with potential 'bonus' payments from the sale of carbon credits). Some referred to it as the Hutan Karbon (the Carbon Forest). Wider discussions allowed for participants (including me) to get on the same page with regards to what was the object of analysis. Although focus groups have shown how social interactions can be a productive tool in geographical research (McGregor, 2005), I was conscious of what group-based discussions might mean for participants' feelings of safety and willingness to participate in a context where I did not know what was at stake.

Semi-structured interviews unfold in a conversational manner offering participants the chance to explore issues they feel are important. An advantage of using this sort of ethnographic interviewing was that I could be more sensitive and attentive to the stories individuals wanted to tell, "allowing interviewees to construct their own accounts of their experiences by describing and explaining their lives in their own words" (Valentine, 2005:111). Semi-structured interviews were a method that enabled the research participants and me to explore how people understood REDD+ and what they sought to gain from it.

The sample of participants was representative with regards to 'experience' rather than externally observable differences. They were experts in the issues under investigation; 
they were willing to participate without purposeful coercion, and had the time to share the necessary information (see Table 4.1).

Table 4.1: Research participants' locations and community group affiliations

\section{RESPONDENTS}

VILLAGE

SUB-VILLAGE COMMUNITY GROUP

(n)

Male Female

\begin{tabular}{|c|c|c|c|c|}
\hline \multirow{3}{*}{$\begin{array}{l}\text { Mendawai } \\
\text { Seberang }\end{array}$} & \multirow{2}{*}{ Sei Gandis } & Kelompok Sei Gandis & 7 & 3 \\
\hline & & Unaffiliated & 2 & 0 \\
\hline & Sei Lamandau & Unaffiliated & 4 & 2 \\
\hline \multirow{4}{*}{ Mendawai } & \multirow{2}{*}{ Karananya } & Danau Seluluk Jaya & 6 & 7 \\
\hline & & Unaffiliated & 7 & 4 \\
\hline & Mendawai & Cabe Rawat & 0 & 7 \\
\hline & RT23 & Unaffiliated & 4 & 1 \\
\hline \multirow{6}{*}{ Terantang } & \multirow{2}{*}{$\begin{array}{l}\text { Kumpai Batu } \\
\text { Atas }\end{array}$} & Tani Sejati & 8 & 1 \\
\hline & & Unaffiliated & 6 & 3 \\
\hline & \multirow{2}{*}{$\begin{array}{l}\text { Kumpai Batu } \\
\text { Atas }\end{array}$} & Mawar Bersemi & 7 & 2 \\
\hline & & Unaffiliated & 4 & 3 \\
\hline & \multirow{2}{*}{$\begin{array}{l}\text { Kumpai Batu } \\
\text { Bawa }\end{array}$} & Setia Kawan & 6 & 1 \\
\hline & & Unaffiliated & 6 & 2 \\
\hline \multirow{4}{*}{ Tanjung Puteri } & \multirow{2}{*}{ Tanjung Puteri } & Sepakat & 9 & 0 \\
\hline & & Unaffiliated & 5 & 3 \\
\hline & \multirow{2}{*}{ Pendulangan } & Wanita Mandiri & 0 & 6 \\
\hline & & Unaffiliated & 0 & 2 \\
\hline \multirow{2}{*}{ Tempayung } & $\begin{array}{l}\text { Tempayung } \\
\text { RT1 }\end{array}$ & Unaffiliated & 4 & 2 \\
\hline & Babual Baboti & Unaffiliated & 4 & 3 \\
\hline Total & & & 89 & 52 \\
\hline
\end{tabular}


I determined the selection of these participants through informal visits to farmers' groups meeting spots or private homes. I then spent between a few hours and a few days (up to five days on several occasions) with the participant(s), in casual conversation and observation.

I would often triangulate the enquiry through different questions or similar questions to different participants. For example, when I interviewed people about how they felt about orangutans or crocdiles being introduced to the reserve, some people would recite tall tails about orangutan attacks. I would always validate those claims, just to find out if they were being said to impress me or if they were genuine. I also probed or deepened areas of inquiry with some participants with whom I developed stronger relationships. I used a set of a dozen or so guiding questions and typically asked most of them. I also explored any other issues that came up and often gently prompted participants to expand their responses. Through these potentially mundane and ordinary conversations I was trying to connect the emotions, interactions and practices of daily life in Sungai Lamandau across multiple scales of REDD+ implementation in an effort to dismantle the customary divides of intimacy and geopolitics (Pain \& Staehili, 2014). At the same time I remained constantly aware of my own research practices of pursuing intimate stories and how that affected the emotions, interactions and practices of daily life associated with a REDD+ project that I was co-creating.

Participants were reminded that they could decline to answer questions, and could stop the discussion at any time. Consent was gathered verbally. I was conscious that written consent forms listing my terms and conditions for their participation restricted negotiation in how respondents wished to be represented. I also did not want respondents to feel that they were contractually obliged to take part, just because they 
had signed something to that effect. All respondents were given my Indonesian and New Zealand phone number and email address, should they at any time wish to withdraw from the research before publication of findings. When a photo was used, it was used with expressed permission, usually conveyed by text message, or face-to-face where practicable.

Where participants had stated a preference to being filmed while working and talking together, they were also given the opportunity to review the footage and erase it if they were not satisfied with how they had been represented. No one requested this. Almost all respondents mentioned their enjoyment at watching and listening to our activities recorded for video and sound. It allowed them the opportunity to reflect on their everyday lived realities and provided me with a greater contextual understanding to what I would not fully understand would I have been watching alone. Others, who preferred to have no audio or visual record, preferring written note-taking, were given the opportunity to check the notes for accuracy. While most people consented to having their real names used in publications, I decided not to use them. This was largely to protect respondents' anonymity, just in case their personal situations or views were to shift in the future. While some of the participants may still be identifiable to those who are familiar with the case, differentiating between them by using pseudonyms and the date of the interview (e.g. Peter: 14 November 2013) is an attempt to protect their identities from outside actors.

One of the most challenging parts of the research was identifying actors who were affected, or stood to be affected by the project, but who were not participating in the project in any formal capacity. I recruited most of these people at weddings. I was continually invited to weddings. It was a great opportunity to meet people outside of the 
formal REDD+ groups. The vast majority of people approached for comment at these events had no idea what REDD+ was. I was usually the first person that had ever talked to them about the project, and I would probably be the last. Occasionally however, someone did know about it and agreed to take part. A clear pattern soon emerged concerning those who knew about the project, but did not formally engage in the project activities. Most of those who had limited access to land did not join a REDD+ group or take part in the project in any formal capacity. A snowball sample ${ }^{16}$ developed as I asked these participants to name other landless actors who might be interested in participating in the study. Snowballing proved to be very effective and I was able to interview a wide range of people that had very interesting and relevant stories to tell, despite their lack of formal involvement in the project activities.

\subsubsection{GROUP OBSERVATIONS}

In order to explore how Sungai Lamandau's farmers and small-holders formally engaged with the REDD+ project, I acted as a participant observer at every PKB meeting, as well as meetings held by each of the PKB constituent groups. Being integrated in the groups' intimate practices (Pain \& Staehili, 2014) as much as possible enabled a nuanced exploration of social life through an engagement with non-verbal forms of interaction between people and circulating emotions (Hoggart et al., 2002; Davies \& Dwyer, 2007; Pain \& Staehili, 2014). It also provided a means for identifying silences and exclusions, for instance what was not discussed and who was silenced - things that are not typically included in meeting reports.

\footnotetext{
${ }^{16}$ Snowball sampling is a technique where existing study subjects recruit future subjects with similar characteristics from among their acquaintances.
} 
As well as observing the interactions going on within groups, I also supplemented semistructured interviews with video recording where appropriate. These observations privileged the individual respondent and formed part of the interview process. Some respondents did not wish to be recorded in this way or acted too uncharacteristically when filmed. Interview transcripts alone often do not tell one much about the atmosphere of certain locations or how people look at one another. For example I interviewed one particular group leader along with his colleagues who wanted rid of him, but they could not ever say that to the leader's face. Witnessing these sorts of power dynamics play out was very useful. This sort of observation was just as important as the spoken words that ended up on codified interview transcripts. These observations deepened my understandings of the case study, as well as creating conversational spaces in which people could directly or indirectly shape the project.

Twenty-eight group meetings were observed and audibly and/or visually recorded, when appropriate. As well as joining formal meetings I also observed and assisted at various gotong royong (voluntary communal work efforts) ${ }^{17}$. These activities were ideal for making friends and introducing myself to potential research participants. Many of the discussions occurred during or after a group meeting or gotong royong (see Table 4.2).

\footnotetext{
${ }^{17}$ Common across Indonesia, 'gotong royong' can include projects such as mending walls, cleaning streets or sometimes even laying tarmac or larger civil engineering projects - see Bowen, 1986 for a broader discussion on its misappropriation in Indonesia.
} 
Table 4.2: Group meeting observations, dates and meeting purpose

\begin{tabular}{|c|c|c|c|c|}
\hline Group & $\begin{array}{c}\text { Date \& } \\
\text { Purpose }\end{array}$ & $\begin{array}{c}\text { Date \& } \\
\text { Purpose }\end{array}$ & $\begin{array}{c}\text { Date \& } \\
\text { Purpose }\end{array}$ & $\begin{array}{c}\text { Date \& } \\
\text { Purpose }\end{array}$ \\
\hline \multirow{2}{*}{ Kelompok Sei Gandis } & 14 July 2013 & 15 Sept 2013 & 14 Oct 2013 & 15 Nov 2013 \\
\hline & Group Meeting & Group Meeting & Group Meeting & Group Meeting \\
\hline \multirow{2}{*}{ Danau Seluluk Jaya } & 12 July 2013 & 15 Sept 2013 & 8 Nov 2013 & \multirow{2}{*}{ - } \\
\hline & Group Meeting & Group Meeting & Gotong Royong & \\
\hline \multirow{2}{*}{ Cabe Rawat } & 22 May 2013 & 20 June 2013 & & \multirow{2}{*}{-} \\
\hline & Group Meeting & Group Meeting & & \\
\hline \multirow{2}{*}{ Tani Sejati } & 18 June 2013 & 20 Sept 2013 & & \multirow{2}{*}{-} \\
\hline & Group Meeting & Group Meeting & & \\
\hline \multirow{2}{*}{ Mawar Bersemi } & 4 June 2013 & 5 July 2013 & & \multirow{2}{*}{-} \\
\hline & Group Meeting & Group Meeting & & \\
\hline \multirow{2}{*}{ Setia Kawan } & 19 Sept 2013 & 22 Sept 2013 & 18 Nov 2013 & 24 Nov 2013 \\
\hline & Group Meeting & Gotong Royong & Group Meeting & Gotong Royong \\
\hline \multirow{2}{*}{ Sepakat } & 23 June 2013 & 22 July 2013 & 21 Sept 2013 & 23 Nov 2013 \\
\hline & Group Meeting & Group Meeting & Group Meeting & Group Meeting \\
\hline \multirow{2}{*}{ Wanita Mandiri } & 4 May 2013 & 4 Oct 2013 & 5 Nov 2013 & 1 Dec 2013 \\
\hline & Group Meeting & Gotong Royong & Group Meeting & Group Meeting \\
\hline Pelangi Kobar & 20 May 2013 & 1 Aug 2013 & 2 Dec 2013 & \multirow{2}{*}{-} \\
\hline Bersatu & Group Meeting & Group Meeting & Group Meeting & \\
\hline
\end{tabular}

It was important to consider whether these meetings were periodic, and therefore more authentic in nature, or if they were motivated by my presence. On one occasion I was asked to join the Wanita Mandiri group for one of their gotong royong activities in the group's nipah groves. I arrived early to find there were around twenty or so women, mostly in their mid to late thirties, clearing foliage and tending to the fruit (see Figure 4.1). 
Figure 4.1: Wanita Mandiri nipah restoration gotong royong session (Left); and Setia Kawan fishpond construction gotong royong session (Right)
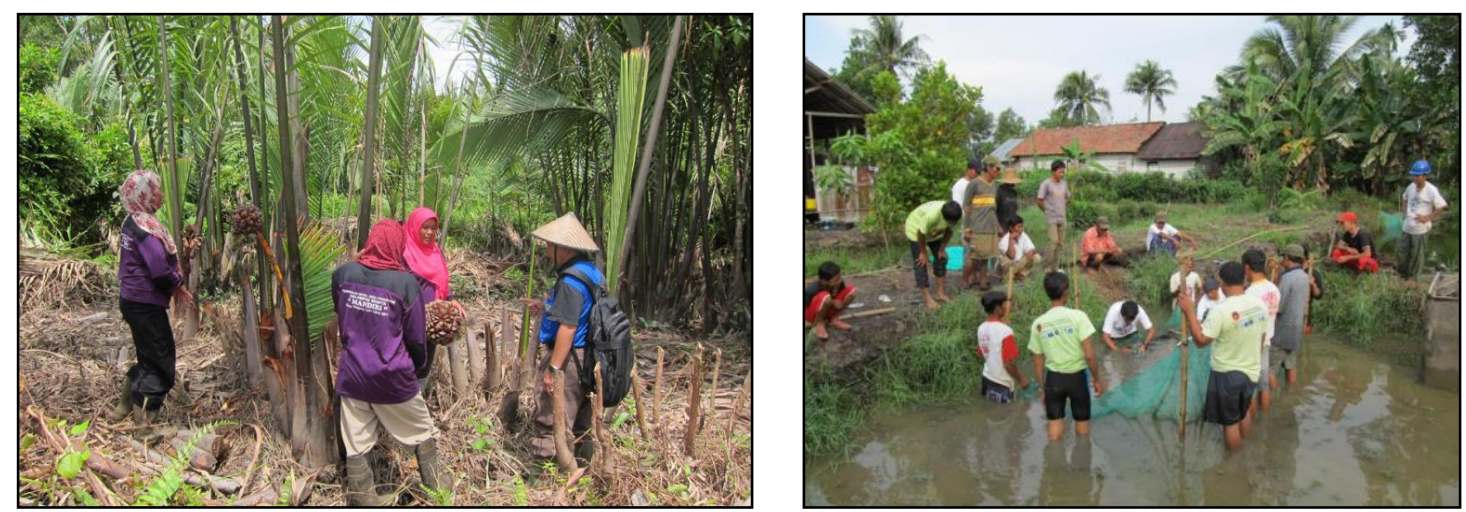

I was taught every-step of the process and I worked with the women until everyone drifted home in the early afternoon. I was invited back to one of the member's homes for tea with her family. I asked her how often they all met up and worked together. She replied:

That was the first time ever. We always make plans to meet and work in the nipah forest, but it never happens. [...] Thank you for agreeing to see the gotong royong. It gave everyone motivation to meet you. (Asih, 4 October, 2013).

Though this was clearly a staged event for my benefit, it had a number of positive outcomes. It had allowed me to build up a good rapport with the group's members; they also committed to meet up every month and I observed a number of these meetings over the following several months. 


\subsubsection{SHORT INTERVIEWS}

To fully understand the diverse range of motivations shaping the REDD+ project, the ethnographic material generated through discussion with the 141 Sungai Lamandau villagers was supplemented with twenty-one discussions with representatives from various institutions.

These short interviews enabled a more nuanced understanding of the intimate relations, interactions and practices connecting nodes of REDD+ implementation (Pain \& Staehili, 2014). Using an intimacy-geopolitics frame I was able to move beyond a simplified understanding of anonymous strategic geopolitical 'players' that form the foundations of a REDD+ project (Tuathail, 1996). The narrative communicated in project documentation for example, discussed a strategic alliance in Sungai Lamandau between international stakeholders to conserve Central Kalimantan's forests (RARE, 2010). In reality these seemingly 'strategic' linkages were profoundly intimate; the result of friendships formed in university dorm rooms in Jakarta, or holidays in Bali.

The institutional representatives included: the project implementers, Yayorin and CCI; heads of local corporations, including KORINDO Sawmills, Sawit Sumbermas and the Citra Borneo Indah Oil Palm company; NGO staff members and volunteers, including Orangutan Foundation Indonesia (OFI) and Orangutan Foundation UK (OFUK); the project's compliance assessors, Winrock; as well as local and provincial government staff and civil servants including, the District forestry bureau (Dinas Kehutanan); and National Conservation Office (BKSDA) (see Table 4.3). 
Table 4.3: Short interview participants, positions, interview locations \& dates

\begin{tabular}{|c|c|c|}
\hline ORGANISATION & POSITION & LOCATION / DATE \\
\hline \multirow{2}{*}{ OFUK } & Director & $\begin{array}{l}\text { OFUK Indonesia Office / } \\
\text { May } 2013\end{array}$ \\
\hline & Programme Manager & $\begin{array}{l}\text { YAYORIN office / } \\
\text { November } 2013\end{array}$ \\
\hline YAYORIN & $\begin{array}{c}\text { Director }+ \\
\text { Programme staff x } 6\end{array}$ & $\begin{array}{c}\text { YAYORIN office / } \\
\text { June-December } 2013\end{array}$ \\
\hline CCI & Programme Officer x 2 & $\begin{array}{c}\text { Peninsular Hotel, Jakarta / } \\
\text { April } 2013\end{array}$ \\
\hline Citra Borneo Indah & $\begin{array}{c}\text { Business Development } \\
\text { Manager }\end{array}$ & $\begin{array}{c}\text { SwissBell-Inn Hotel, P'buun / } \\
\text { October } 2013\end{array}$ \\
\hline KORINDO & Production Manager & $\begin{array}{c}\text { Blue Kecubung Hotel, P'buun / } \\
\text { September } 2013\end{array}$ \\
\hline Sawit Sumbermas & Finance Manager & $\begin{array}{l}\text { SwissBell-Inn Hotel, P'buun / } \\
\text { June } 2013\end{array}$ \\
\hline Winrock & $\begin{array}{l}\text { Programme Director }+ \\
2 \text { x Programme Officers }\end{array}$ & $\begin{array}{l}\text { Skype (Virginia, USA) / } \\
\text { September } 2013\end{array}$ \\
\hline Bupati's Office & Deputy Bupati & $\begin{array}{l}\text { Bupati's office / } \\
\text { November } 2013\end{array}$ \\
\hline BKSDA & Director & $\begin{array}{l}\text { BKSDA office / } \\
\text { July } 2013\end{array}$ \\
\hline Dinas Kehutanan & Protection Director & $\begin{array}{c}\text { Dinas Kehutanan office/ } \\
\text { May } 2013\end{array}$ \\
\hline OFI & Director & $\begin{array}{l}\text { P'buun Airport / } \\
\text { December } 2013\end{array}$ \\
\hline
\end{tabular}

These discussions lasted around an hour or two, often taking place over lunch. I attended each interview with around four or five pre-prepared questions committed to memory, but I allowed the respondent to guide the discussion as well and ask questions of me. I tried to be useful. I gave feedback and recommendations for further action when appropriate. In doing so I maintained a rigorous methodology, as well as a commitment to bring about positive change.

However, debates concerning this kind of blending of political commitments with scholarly research agendas raise epistemological questions about the nature and value 
of research as well as political questions about how scholarship might act in conjunction with struggles for social justice (Mendez, 2008).

\subsubsection{RESEARCH METHODS WITH AN INSURRECTIONARY IMAGINATION}

Although I remained committed to incorporating social justice goals into my research, I stayed mindful of, and grappled with, the dilemmas associated with collaborative praxis, without the illusion that these processes could ever be contradiction-free. Yet, given the ongoing economic, political, and ecological crises confronting humanity, aspiring scholar-activists need to enter the logics of an insurrectionary imagination (Derickson \& Routledge, 2014). This approach rejects the notion that the researcher should (or could ever ethically be) fully objective and detached from the research participants and audience. After all, "The point [...] is to change it" (Marx, 1888: 13).

The research design attempted to ask and answer questions that the more marginalised research participants wanted to know. In doing so it addressed the need for research to explore barriers to sustained and active participation and activism. It sought to understand the challenges that research participants faced in affecting the change they wanted to see (or had not yet imagined) and how social relations might be transformed in ways that created the conditions for realising their conservation priorities.

The aim was to put into practice principles of solidarity, equality, pluralism, and horizontality to inspire a counter-power to the dislocation associated with market based environmental management (Derickson \& Routledge, 2014). This involved a politics of prefiguration - fashioning alternatives through lived practice while also 
recognising that such practices constantly require the negotiation of unequal power relations (Chatterton et al., 2008).

I did not share the optimistic view that certain types of economic valuation could produce favourable social and ecological outcomes for REDD+ in Sungai Lamandau (see for example Corbera, 2014). Coming from the perspective that monetary valuation is ultimately about advancing capitalist forms of governance, I believed that it would not just lead to the oversimplification of ecological complexity, but would further embed neoliberal ideologies (see Matulis, 2014). My role as a scholar-activist was to actively seek out usually marginalised voices and experiences, as well as to open up different kinds of conversations and imagined possibilities for the alternative REDD+ that might evolve.

The need for an alternative course became obvious to me during a weekly gotong royong session with the men's groups of Terantang. It was obvious that only landed people, or those that had secure access to forest resources were participating in the REDD+ project. On my way home from the session, I visited two landless families, who had not joined an affiliated community group, at their homes in Kumpai Bata Bawa. After several hours of conversation they explained to me of their reliance on poaching in the Sungai Lamandau forests. They had also needed to clear land in secret to grow food and rubber trees to supplement their income from farm labouring (explained further in Chapter seven). It was obvious that those who could have benefited the most from the project's interventions were being further marginalised. Yet, just as I operated with a research agenda, most other research participants also had theirs. 
An extensive body of literature critiques the researcher-researched categorisations (see for example England, 1994; Rose, 1997). However, much less attention is given to those who do not fit easily into either category. While the literature discusses 'gatekeepers' (Hay, 2010), few authors have seriously considered the positionality of research assistants, guides and other intermediaries (Nelson, 2013: Turner, 2010). Irfan for example, was such an intermediary, acting as both a guide and a critical cog in the development of Sungai Lamandau's REDD+ project. As a paid Yayorin volunteer, a good working relationship with Irfan was essential, not only because he knew almost everyone involved in the REDD+ project, but also because he was the only member of the project implementing consortium that was willing and able to help me navigate the study site, introducing me to local leaders and group members.

Irfan was also the leader of a rubber collective, and his sister was the leader of a women's palm sugar collective. He also had aspirations of standing to be the local Kepala Desa (elected village-level representative) for Tanjung Puteri. He owned tenhectares of land in Pendulangan and operated an estate agency on the outskirts of Pangkalanbuun. Irfan's interest in the project was mostly for personal reasons. Success would result in a lot of newly valuable land in and around the project site. His own land, relatively low in monetary value, would rocket in price, should the project need to expand like other conservation projects had done in Kumai and elsewhere (explored later in Chapter seven). Although I had nothing against the idea of Irfan aspiring to become a wealthy businessman, I was not at all interested in facilitating that kind of project formation. In terms of generating an insurrectionary imagination, I found little cause for celebration in Irfan. Yet, as Sultana (2007) observes, few scholars openly speak of the collaborations, connections, and solidarities that did not materialise, or that 
could not come to fruition in the research process. The mutuality of these processes did not hinge only on me as the researcher, even though I did feel the burden to initiate, sustain, and nurture such relationships. The roles of people at the other end of potential relationships were important to the ways that the relationships were allowed to form and play out.

In trying to understand how research participants, like Irfan, valued resources, I had to be careful not to impose the idea that project benefits could be valued monetarily in any explicit sense. However, there were significant ethical implications that come with such activist manoeuvring that is critical of market-based environmental management practices. Opportunities to accumulate wealth in rural Kalimanatan were sparse for most farmers. To impose my ideas for equitable project outcomes could be interpreted as the reification of colonising processes. However, these are difficult, neo-liberal times (Derickson \& Routledge, 2014). Researchers must actively put up resistance within valid sites of struggle and knowledge production (AGC, 2010). This commitment can trap scholar-activists between two worlds and sets of people with competing priorities, expectations, and pressures. Furthermore, decolonising research is not about the rejection of 'Western' theory, research, or knowledges. It is about changing focus and confronting ideologies of oppression (Louis, 2007), such as those propagated through market environmentalism.

I did not set out to do scholarly activism. Most researchers don't (Kiang, 2008). And nobody has the same idea about what an activist is or should do (Hale, 2008). The common goal is to reconfigure knowledge production so as to shift power and control into the hands of the oppressed or marginalised, privileging 'subjugated knowledges' (Collins, 2000) and transforming oppressive social structures (Mendez, 2008). Like with 
any other reflexive activity, as an activist, my critique was guided by unique emotional responses, core values and politics. Politically, emotions are intimately bound up with power relations and also with relations of affinity and are a means of initiating action. People become politically active because they feel something profoundly - such as injustice or ecological destruction. It is people's ability to transform these feelings about the world into actions that inspire them to participate in political processes. (Chatterton et al., 2008; Routledge, 2012).

Using these methods exercised through an insurrectionary imagination, the following section explores how REDD+ knowledges and claims to truth were co-created in exclusive and gendered spaces of power.

\subsection{EXPLORING SPACES OF POWER}

\subsubsection{NAVIGATING GENDERED SPACES IN SUNGAI LAMANDAU}

Feminist geographers have contributed to developing a nuanced understanding of the operationalisation of power in the different spaces occupied by women and men - such as work, home and leisure - highlighting the slippage which may occur between feminine and masculine subjectivities as individuals move between these spaces. Gregson \& Rose (2000: 441) make the case that "it is not only social actors that are produced by power, but the spaces in which they perform", suggesting that "we need to think of spaces too as performative of power relations". Highlighting the subtleties which exist in the relationship between power, performance and differing spatialised subjectivities, Gregson \& Rose (2000) move on from understandings which emphasise active, conscious performance, and those offered by Butler's (1997) more discursive 
approach. They suggest, instead, that the instability and slippage evident between performances and the spaces in which these take place point towards the potential for subversion and disruption, as well as highlighting a much more complex and messy relationship between power, different spaces and the performances which take place within them. For Gregson \& Rose, the emphasis is on exploring the 'relationality' of performance and how the blurring of clear distinctions between positions and spaces is a source of performative instability. Meah (2013) argues that this way of rethinking the relationship between gender, power and space is a useful conceptual tool for reexamining the gendered spatial dynamics of labour division and the blurring of its boundaries with other seemingly unrelated spaces.

Men's work in the rubber-tappers' settlement of Sei Gandis for example, and many other villages in Sungai Lamandau, was lonely work. Days at a time were spent away from the family home, sleeping in small pondok (single-room huts), without electricity. Domestic work on the other hand, was crowded and social. The monthly Sei Gandis groupmeetings, held for the men in one of the cramped riverside dwellings, were for some the only opportunities to pray, gossip and eat together. Discussions concerning the group's business affairs were reserved exclusively for men. Women occupied the busy kitchen space or took turns distributing tea and snacks to the male contingent.

If researchers only visited Sei Gandis on group-meeting days, as many researchers often did, they would see a violent relegation of women's voices. For the rest of the month, men's spaces of work were apolitical and lonely. Women mean-while were left to manage the day-to-day operation of the community settlement in crowded, noisy, and political spaces of domestic work. 
Since housework is not generally regarded as contributing to the productive economy of households (Meah \& Jackson, 2012), women's domestic engagements have often been regarded as taken for granted, lacking in value, socially derided or downright oppressive (see, for example, Charles \& Kerr, 1988; DeVault, 1991; Giard, 1998). In Sungai Lamandau, there was a clear need for a more nuanced understanding of the geographies of domestic power which reconfigured the kitchen as a site of REDD+ decision making rather than oppression. Assumptions of how housework is valued highlights the relevance of Christie's (2006: 659) reminder that, as long as researchers

look for women's participation and power in places where they are not, and ignore the less visible, accessible, or 'desirable' places where they are, research is more likely to reflect our own ideological positions than the reality of women's lives and spaces around the world.

Considering my positionality as a Western male researcher, navigating the gendered spaces of power in Sungai Lamandau was not straightforward. Aside from the fears raised by more obvious obstacles encountered in the field, this issue of access arouses great anxiety among geographers concerned that the accuracy of their findings would be put into question on the basis of an oppressive masculinity (Falen, 2014).

\subsubsection{ACCESS DENIED?}

The problem of access is a vexing one for social science researchers. One can carefully plan out the minute details of an ethnographic project, but one is always at the mercy of 'key informants', intermediaries and the participants themselves to provide access to their lives. Access here is always conditional and partial, but also negotiable. My 
positionality mediated my access capabilities to both the women's groups and men's groups of Sungai Lamandau, but also to those less visible. Negotiating access to genderspecific spaces within the predominantly Muslim communities of Sungai Lamandau was particularly challenging. The cultural gender norms often made cross-gender interactions prohibitive (see also Wax, 1979), including certain same-gender spaces, such as prayer rooms or kitchens during formal meetings and functions. Privately interviewing lone women would also violate community gender norms.

While raising these access dilemmas is an important part of reflexive ethnography, the sense of frustration and often fatalism that accompanies these descriptions is prominent. Despite these feelings one should remember that human geography as a discipline would look very different if personal backgrounds were thought to prevent access and achieving the rapport necessary to understand the 'Other' (Falen, 2014). Yet, one often takes for granted that a researcher's gender may be reason to question his or her findings (Kulick, 2014). For male ethnographers, this often means they feel unqualified to speak about women. As Berliner (2008) points out, this view of separate gendered worlds assumes an essentialised gender identity, and although western academics, like me, may deconstruct the categories of gender, these categories are frequently unquestioned in the host cultures being studied. Of course, there are numerous examples of how my gender interfered with the fieldwork process, so I do not suggest that gender is insignificant. I am also not suggesting that I was, as a male researcher, better placed in understanding women's struggles than my female colleagues. My concerns about the limited value of my cross-gender pursuits however, existed larger in my fears than in reality. Therefore, I argue that research on the ways in which women and men experience space and place is important for any meaningful 
discussion on access and exclusionary dynamics, regardless of the researcher's gendered positionality.

When access is denied to 'women's space' what impact does this have on one's descriptions, theories, and analyses? The question is especially important today, as essentialist views of gender have been widely debunked in the social sciences (Schilt \& Williams, 2014). Stereotypical beliefs that 'all women think alike' and have universal interests in common have been challenged by feminists who embrace post-structuralist, third wave, and queer theory perspectives (Fraser, 2013). Those outmoded beliefs contributed to professional norms that only women could (and should) interview women. Today, equipped with concepts such as intersectionality and reflexivity, any topic should be open to any researcher, regardless of gender, or race, or sexuality, or any other group identification (Schilt \& Williams, 2014).

However, all ethnographers must recognise the obstacles they face in researching the lives of men and women, representing the women's voices which may have become marginalised through a historically dominant 'masculine' ethic of control. Yet, being male is not a defect robbing men of an ability to do this successfully. Just as to ignore women in our research blinkers our view of the social world, ignoring the capacity for male researchers to assist in a feminist struggle is just as misguided.

My partial access to the perceived 'women-only' spaces of Sungai Lamandau, was partly enabled through my life-partner ('wife'), Sarah ${ }^{18}$. This partnership also enabled me to navigate other social spaces much more effectively. Sarah also assisted in making sense of my findings by offering her reflections on what she had experienced in her

\footnotetext{
${ }^{18}$ Sarah was also proficient in Bahasa Indonesia. We had lived and worked together in Makassar, South Sulawesi for several years. Although I relocated to KoBar alone, she joined me within a month or so of my moving there, and stayed for eight months until she found a permanent job in Bogor, West Java.
} 
discussions. However, I ultimately had to make decisions about what analytical orientation and conclusions to draw and how to theorise these in the thesis. Values concerning conservative gender roles and heteronormativity undoubtedly influenced what women were prepared to talk to me about. However, I acknowledge that some questions and knowledges will also remain hidden in this respect.

There is a strong connection made between marriage, and ideas of harmony over selfinterest in Indonesia; or as Karim (1995: 16) put it:

the need to maintain social relationships through rules of complementarity and similarity rather than hierarchy and opposition, and the need to reduce imbalances of power through mutual respectability and cooperation, rather than oppression and force.

Following this line of thought, other scholars have emphasised how a moral hierarchy of 'family', in Indonesian society, "stresses the well-being of the collective through the enactment of social roles and obligation" (Adamson, 2007: 6). In other words, conjugal partnership is a means by which the unsettling desires of the individual can be domesticated, so that community order and stability can be maintained (Brenner, 1998). Sarah and I, participating in the research together for eight of the total ten months of fieldwork, enabled an acceptability that I struggled to keep as a single, lone, male researcher. This I realised once Sarah had returned to her place of work in West Java. Although I realise that this partnership enabled a somewhat partial insight into certain women-only spaces, I also realise that all knowledge is always particular and partial. 
When appropriate, I also 'crossed over' into the spaces of women's performances, even if this did cause embarrassment or confusion. Challenging the prevailing gender order demonstrated its social construction, and with good humour, perhaps brought into question the boundaries and the binaries that organise social worlds. It is to be expected that norm violation would be met with reproach, but this can also be a source of social change, and an opportunity to learn more about how gendered power operates, and how it affects us all (Schilt \& Williams, 2014). The central issue here was how, as a man, I could do feminist ethnography, establishing credibility and value without having to draw on male cultural capital, or assert male privilege, to do so (Newton \& Stacey, 1995). Patriarchy continued to work in and through me despite my feminist convictions. These convictions perhaps provided an alibi for the assertion of my male privilege in subtle ways. In this respect, it is difficult to judge whether my contributions to the feminist struggle were 'crucial', but I am suggesting that they were 'useful' in enabling a partial insight into the lives of Sungai Lamandau's women and men, that could not ethically be ignored.

As well as gender considerations, there were also the issues of race, ethnicity and religion to contend with. Feminist geographers have long grappled with theorising power as intersectional, yet assumptions that researchers are in authority always and everywhere, while those 'studied' are inherently marginalised on the basis of race, and gender, continues to naturalise difference.

Faria and Mollet (2014) highlight the historically contingent and visceral workings of race experienced during fieldwork illustrating how racialisation and, in particular, how 'whiteness' is felt, produced, dismantled, and remade through situated and momentary feelings of awe and disdain, trust, and suspicion. Race here is destabilised; rendering it 
'unnatural' and brought into being through embodied, intimate acts. In this way Faria and Mollet (2014) demonstrate the salience of emotion in composing, recomposing, and revealing interwoven gendered and racial ideologies at work. These workings of whiteness remind feminist geographers of the intersectionality of gendered and racial power. Though long argued, this remains a collective intellectual imperative. In turn, it offers ways to think methodologically about intersectionality, through a connected feminist and postcolonial reflexivity.

Indeed, being reflexive about my position while doing fieldwork in Sungai Lamandau was complicated. At the time of writing this thesis, I had lived in Indonesia for over fouryears. Two-years were spent in South Sulawesi, working for the Forestry Department, the rest of the time in West Java and Kalimantan. I developed a fluency in Indonesian (Bahasa Indonesia) as well as cultural understandings and traditions of etiquette. Despite this, I had always been conscious of feeling like an 'outsider' due to my height. As a six-foot-three Englishman, I stood out quite plainly amongst a crowd of Indonesian people, with an average height usually a foot shorter than me (see Figure 4.2).

Figure 4.2: Me, standing with Yayorin volunteers
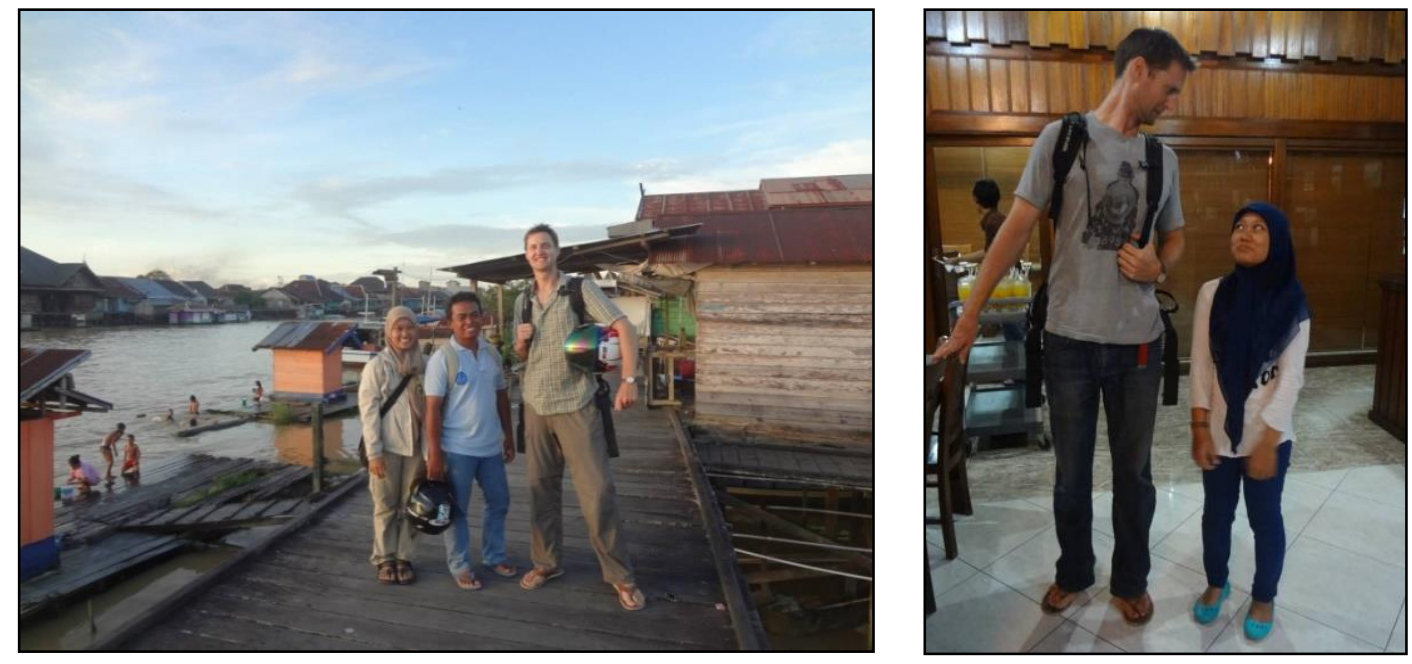
I was understood as an outsider, but this had many benefits. I was not affiliated with the Javanese project implementers nor was I a 'local'. My constant negotiation between various degrees of difference and similarity meant that I was never an 'outsider' or 'insider' in any absolute sense (Nast, 1994). Not only did being a white, male outsider enable an intimacy-geopolitics approach to work; it allowed an increased level of openness which others might not have been privilege to. Women and men confided in me concerning all sorts of issues that they would rarely share with an insider. This raised opportunities and questions of how I could play with different positionalities to build rapport with different people, while being attentive to the ethics and politics involved in such processes of 'fitting in'.

While it has been argued that reflexivity, just like considerations of knowledge production, can result in navel-gazing, being reflexive about one's own positionality and how one 'fits in' is not self-indulgent (Sultana, 2007). It is highly important to reflect on how one is inserted into grids of power relations and how that influences methods, interpretations, and knowledge production (Kobayashi, 2003). It is also implicated in how one relates to research participants and what can/cannot be done vis-à-vis the research within the context of institutional, social, and political realities. As such, it is integral to conducting ethical research. Peake and Trotz (1999:37) argue that acknowledging one's positionality or subjectivity

can strengthen our commitment to conduct good research based on building relations of mutual respect and recognition. It does, however, entail abandoning the search for objectivity in favour of critical 
provisional analysis based on plurality of temporally and spatially situated voices and silences.

\subsubsection{ACCESSING THE EXCLUDED}

Reflections of my positionality enabled me to understand how relations of power shaped research processes and outcomes, and drew particular attention to my role as the researcher in these power relations. Reflexivity contrasts with approaches rooted in masculine traditions which position the researcher as a detached, objective authority (Bondi, 2009). Instead, knowledge (relating to REDD+ and anything else) is seen as coproduced between people participating in the research. The 'researched' are therefore framed and understood here as participants, rather than mere objects of study. The spaces where knowledge was co-produced were accessible to those with the capability to do so. Attempts to redistribute power more evenly between myself and other research participants, and avoid reifying social exclusions, were an essential part of the reflexive process (see also Kitchin \& Tate, 2000).

However, there were significant constraints concerning the exploration of REDD+ as a partially-formed object of analysis. I was regularly asked to give examples of REDD+ projects in other parts of the province. In preparation for my field research, I had visited most of them and had spent time prior to entering 'the field' reading the English language PDDs for each of the projects. I was often asked to facilitate sessions with Yayorin staff for the PKB group, which would enable them to devise a PDD for the Sungai Lamandau project. This included a social and environmental 'safeguards' plan; a monitoring plan - covering biodiversity, conservation value, and community development. Without doubt, this assistance impacted how REDD+ manifested in Sungai 
Lamandau. As I have explained in the previous section, my intention was to communicate the infinite possibilities for the project. It was my feeling that most group members had a very limited interest in the potential monetary deliverables and I had no interest in promoting those as potential incentives. To institute a research agenda which sought to understand REDD+ as a financialised conservation mechanism, would perpetuate capitalist ideals and mentalities regardless of the immediate material outcomes.

The meeting spaces, where the co-production of REDD+ knowledges took place, were exclusive. Through my role as a researcher, I was therefore partially complicit in the reification of exclusionary regimes of knowledge production within these spaces. By respecting the distinct gender divisions within family homes I was deeply complicit in their reification. In Sei Gandis for example, all group meetings took place inside a small hut that could fit only ten to fifteen men. Within this space, a clear delineation was obvious between those who stood to access the project's REDD+ benefits, and those who might not have. It was therefore easy to identify excluded actors who perhaps wished to participate in the research - to learn about their concerns, needs and hopes for the project. In group meetings I would often sit with people I either had not met before, or people I knew to be 'disadvantaged' (i.e. lacking access capabilities - explored later in Chapter five). I would also encourage Yayorin staff, who facilitated the project meetings to position themselves so that guests sat outside, could at least hear, if not be heard (see Figure 4.3). 


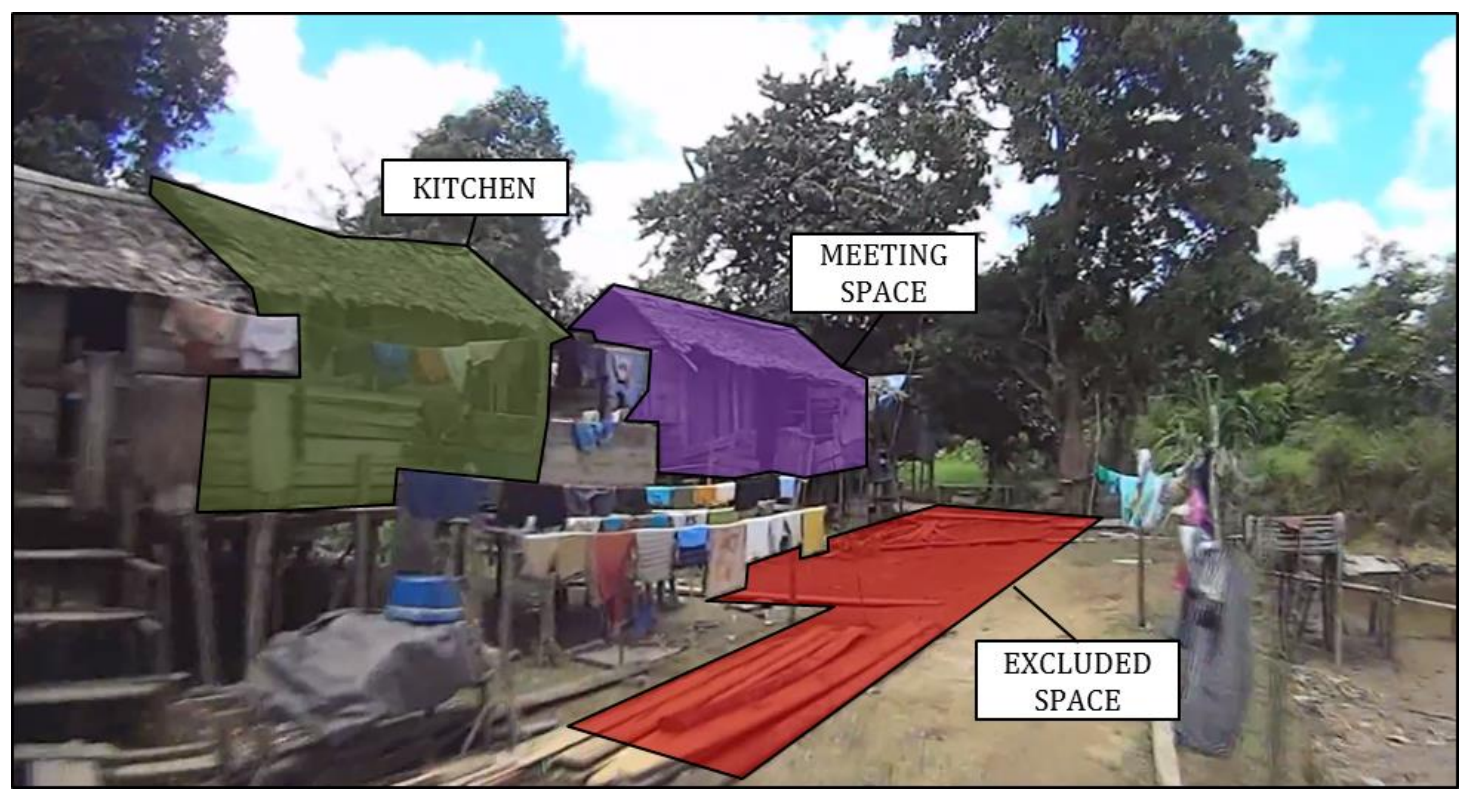

Negotiating access to participants, poses challenges for all social research, but this can be particularly exacting in ethnographic projects which require participants to consent to prolonged research encounters that can be invasive or disruptive to their social lives. The process is more difficult still when accessing groups that are already heavily scrutinised, and associated with practices that are viewed as socially or environmentally problematic (Nelson, 2013). Some participants identified within an 'excluded space' more readily admitted to being involved in illicit activities. I had the opportunity to spend time with some of these more 'illicit' groups. However, the ethics of peforming this sort of research, together with the challenges of representing these actors' lives, was very difficult. It was impossible for me to guarantee that they could not be identified through my research, so I left their voices out. Furthermore, accessing these excluded actors changed the way my research objectives were perceived by all the research participants. 
The performances of all research participants, including me, were mutually constituted. Responses to questions were dependent upon perceptions and interpretive outcomes. Why the question was asked, was as important as what was asked. The inclusion of participants who were regarded as 'illicit' actors, although essential, confused many of the other participants who had perceived my role as purely to research the implementation of a community-based forestry project, rather than its wider implications. As I occupied the red 'excluded space', this augmented my perceived position within the project. Dominant hierarchies were disturbed as I momentarily disassociated myself from the purple space of formal decision making.

The 'excluded space' continued far beyond the grassy thoroughfare of the Sei Gandis settlement, over the illicit gold mining flats, the logged-over forest concessions and hunting grounds of kijang deer. Just as my occupation of women's domestic spaces caused unanticipated outcomes (some positive, some negative), researching the 'excluded spaces' around Sei Gandis and elsewhere undoubtedly affected both how I was perceived, and the responses I received from the Sei Gandis villagers and further afield. Carrying out 'inclusive' scholarship - including those marginalised actors pushed towards illicit livelihoods - is often considered with a great deal of virtuous intent (Shaw, 2011). Yet, scholarly-activists attempting to 'improve' things are not always welcomed or wanted within these spaces.

\subsubsection{NAVIGATING THE ETHICS OF RECIPROCITY}

Emotional investment in the lives of research participants ensured, most importantly, that I made lasting friendships, but also ensured reliable data was collected. However, 
there is a clear need to consider colonial histories of domination here. Bodies associated with colonising pasts or presents can prompt feelings of inferiority, an emotive reaction to 'whiteness' not always fixed to white bodies. These feelings have significant repercussions for the authority, legitimacy, and access afforded to researchers like me. Yet, researchers may often be too quick to lament over being the colonial 'outsider'. Consider European history for instance; if I do not enjoy the company of one particular rude German man, it would be erroneous to follow a narrative of disdain dating back to the World Wars in order to explain my feelings. In this thesis I do not base my findings entirely on externally observable differences. And I expect respondents did not either. Yet, a question I constantly asked myself was, why did people wish to participate in the research? Was it because they could foresee the potential benefits, or did they feel compelled or coerced into doing so? Did they share my feelings on the need for reciprocity in our relationship or was it an effectual trade - a quid-pro-quo transaction for services?

My involvement had a number of benefits for Yayorin, or rather, the success of the REDD+ project in Sungai Lamandau. Having read so many REDD+ PDDs, I was an attractive asset for an organisation in which only one or two members had more than a rudimentary English language capability. I also agreed to volunteer my time to teach in Yayorin's English school every Sunday. I agreed to pay Irfan for his time as an intermediary (Rp.100,000 per day, plus expenses - \$10 NZ). I was conscious that no such material advantages were offered to the local farmers of Sungai Lamandau who regularly sacrificed their time to participate in the research. On one occasion a member of the all-women Cabe Rawat group had fallen behind in the payment of her iuran (subs/dues). She asked me to loan her Rp.50.000 ( $\sim 5 \mathrm{NZ).} \mathrm{I} \mathrm{was} \mathrm{convinced} \mathrm{however,}$ 
that she was asking me in my capacity as a group member and friend, rather than as a rich outsider with money to spare. Luckily I did not have enough money in my wallet. The nearest bank was two-hours away. I therefore declined to help on these grounds, rightly or wrongly.

For the Wanita Mandiri women's group I was asked to design and print several hundred labels on my computer, which they could use for their prawn crackers. After conducting interviews and observations of the group's activities I would also deliver their prawn crackers to shops and businesses including the Korindo sawmill in Pangkalanbuun. I reconciled this out of a feeling of the need for reciprocity. Many female members of the group catered for me every time I passed through or met with their other family members. They would often feed me three-meals a day for a number of days and house me, sometimes in the family's only bed. I recognised that I had the potential to be a huge burden on the family's resources and an interruption to daily life generally. The least I could do in return was carry a box of crackers occasionally in the direction of home (see Figure 4.4).

Figure 4.4: Dua Udang (Two Prawns) Prawn Crackers Label (Left); and the women of Wanita Mandiri packing crackers with my 'wife', Sarah (Right)
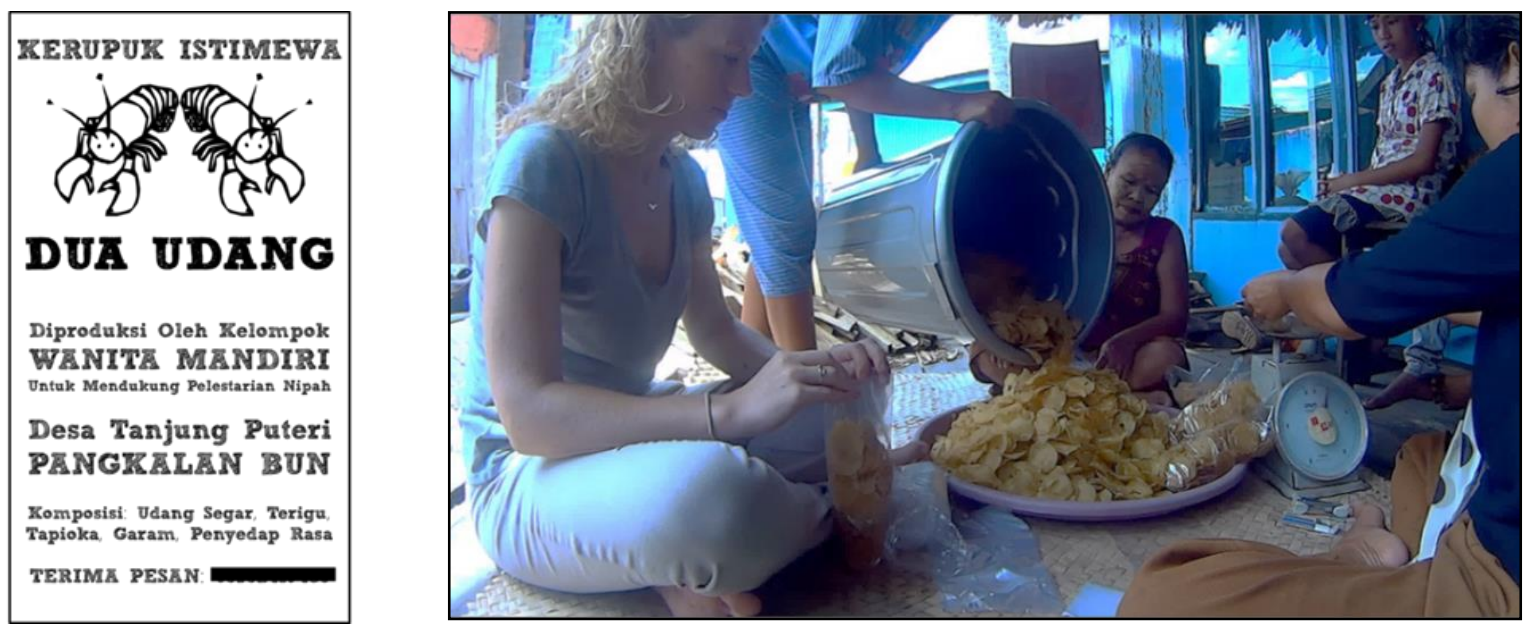
Despite these favours, I did not want to appear affluent and risk attracting requests for things I could not ethically provide. My basic lodgings and rusty old moped reflected my student income. Navigating the fifty-kilometres between the river's northern reaches and the coastal communities of Pendulangan was difficult by moped, but how I arrived to meet respondents was as important as what I said or what I did in terms of the way I was perceived. To get to the palm oil village of Tempayung in the north was easiest by speedboat. It cost Rp 200,000 ( NZD 20) for a return trip and took less than an hour each way. To travel by motorbike would take approximately twelve-hours in one direction. The road was dangerous, broken in places and often closed for exclusive palm oil plantation traffic. But, if I arrived in a speedboat I would be perceived as a rich transient tourist. Being a tourist usually meant that one was either visiting the Tanjung Puting National Park or was affiliated with one of the orangutan sanctuaries, both of which were held responsible for evictions of various groups within the study site. These evictions are described in detail in Chapter seven.

Traveling by moped had the advantage of minimising association with either party. Owning my own moped (rather than renting) and local provincial driving licence also gave an impression of relative permanence and commitment to the area. The disadvantages of motorbike usage were plentiful. Travelling through the small villages of Sungai Lamandau was difficult to do without raising attention. Travelling past a previous respondent without dropping in for a sociable glass of tea was considered disrespectful. I would normally receive a text message or two from a number of respondents as soon as I reached the main thoroughfare of a village. I would therefore have to factor in time to visit each past respondent before visiting a new one. I also had to be conscious that many male respondents would cordially invite me into the 
reception area of the home where we would both sit on the sofa and talk about our plans for the day. However, it was almost always the responsibility of a young female family member to make and serve the tea. Tea had to be served with snacks and the server was always required to be suitably presented in a hijab head covering. If no females were present in the house, then one would be summoned for, or we would go without tea. So I was constantly mindful of the effort exerted by female members of the household, despite my cordial welcome from the family patriarch.

When Sarah was away, being alone in the house was interpreted as the reason I travelled around on my moped calling in on people for research discussions about REDD+. Only once did someone enquire as to why I was in a village that I had visited the week before. Generally, I was always invited in, offered a meal and a place to sleep. "You must not stay at home without an Ibu (older female/wife/mother) you will get sick", I was once told by a female respondent in Terantang (Siti, 4 June 2013).

I would reciprocate kindness whenever possible. I would visit research participants at their homes or in hospital if they were sick. On one occasion, a female group member, whose family lived in West Java needed assistance looking after her two children following the difficult labour of her third child. She had developed severe Bell's palsy, which required treatment in Palangkaraya. Sarah and I looked after her children for several days, until their mother recovered. Where participants had given-up significant amounts of time, allowing me to stay over for a night or two or fed me meals, I gave them a framed photo of us (the respondent and I) as a thank you, with which all recipients were very pleased.

Feminist ethnographic debates have inspired a considerable amount of literature highlighting the usefulness and some of the dilemmas of establishing close and 
empathetic relationships between the researcher and other participants, advocating personal investment in the research process and a degree of emotional attachment to the field and informants (see Taylor, 2011). The literature, together with my experiences shows how encounters in the field will always be personal and partial, dependent on a great number of factors that cannot be prescribed, measured, calculated, estimated or anticipated prior to the engagement. To paraphrase Taylor (2011): as researchers, we have no handbook or manual to follow, no precise way of orchestrating such engagements to ensure a mutually beneficial outcome. To guide oneself as a researcher, one must equally value and rely upon one's strength of character, goodwill, instincts and emotional intelligence just as much as academic training.

The following section explains how my academic training and scholar-activist ambitions influenced the 'writing-up' process and the ethics of representing the respondents effectively and responsibly. The intimacy-geopolitics approach used abandoned universal categories and grand theories, focusing instead on the particular lived realities of Sungai Lamandau's farmers.

\subsection{ANALYSING \& REPRESENTING SUNGAI LAMANDAU}

\subsubsection{DATA ANALYSIS}

I left the villages of Sungai Lamandau with approximately forty-hours of unedited film footage, seventy-hours of audio recordings, several hundred pages of field notes and interview transcripts/notes. The film footage included interviews, recordings of everyday activities and group meetings. It served to 'put me back' while writing. The 
process of 'writing the field' provided as much understanding as being in the field (Cupples \& Kindon, 2014), serving to consolidate my experiences while giving them meaning. I attempted to view memories, film and audio footage, field-notes and interview transcripts with 'fresh eyes and ears' (Kindon, 2012) throughout the writing process. This provided a very rich body of material that could be brought together to provide a thorough understanding of local conditions.

The research findings presented in this thesis have derived from discourse analysis of the interview texts and consolidated field notes. Discourse analysis, as it was used here, went beyond the Marxist perspectives of discourse which provide a convenient method of analysis through which one can see who is on what side by focusing on what they say - their discourse (Rydin, 1998). The 'discourse coalitions' acting within the REDD+ project were so entangled, such an analytical exercise would have been futile. Instead I adopted an analysis which drew on post-structural theory and in particular on the work of Foucault (1977).

For Foucault, discourse is part of a process through which things and identities get constructed. In Foucauldian terms, discourses are not simply reflections or (mis)representations of 'reality'; rather they create their own 'regimes of truth' - the acceptable formulation of problems and solutions to those problems (Foucault, 1980). Language, knowledge and power are therefore all interconnected through discourse. In terms of method, this post-structuralist approach was less interested in attending to who said what to whom, where, when and how. Instead the focus was on wider constructions of REDD+ in rhetoric. This methodological approach draws explicitly on post-positivist theoretical currents in cultural studies (Lees, 2004). Yet in its Foucauldian dress, discourse analysis "is a craft skill, something like bike riding [...] 
which is not easy to render or describe in an explicit manner" (Hoggart et al., 2002: 165). But I will try.

My analysis followed a three-dimensional approach to investigate the intimacygeopolitics (Pain \& Staeheli, 2014) of REDD+ in Sungai Lamandau. This involved three steps: i) text analysis; ii) analysis of discursive practice; and iii) analysis of social practice, not necessarily in that order. The first step scrutinised vocabulary, grammar and text structure. Discursive practice involved analysis of the political context in which the statements were made as were their links to other debates and literatures highlighting the rhetorical organisation of the discourse. Social practice analysis involved consideration of the more general ideological context within which the discourses took place.

For example, the following quote is representative of many Sungai Lamandau's farmer's responses to the question 'Why are you involved in the REDD+ project?'

All of us here are very worried about the future of the forest. I am scared that my children and their children will not have the forest like we have today. There is too much palm oil and greed. It's like that, is it not? Yayorin help us to save the forest. We must go green yes? (Dian, 12 August 2013).

Using the three-dimensional framework, the many hidden meanings trapped in the text becomes clear. For instance, 'go-green' (said in English) connects Dian's response with a common rhetorical construction used by politicians, palm oil businesses and schools in Pangkalanbuun. The municipal government had adopted the designation 'Kota Manis, Kota Bersih' (the sweet town, the clean town), and had launched a 'go green' campaign to keep the town 'sweet' and 'clean' from litter. The general context within which these 
comments were made was confusing. Although I did converse with many respondents who portrayed a deep emotional connection with the forest, many, including Dian - a rice farmer - admitted to never having visited the Sungai Lamandau forests. I am not discounting the sincerity of the text. I am highlighting the need to look a little deeper.

In doing so, the approach used here attempted to move beyond what Locke (2004: 40) refers to as, the "transparency of the utterance" - the mundane miracle of communicability, rendering realities to textual facts. I was more interested in why things were said than what was said. However, the discursive meta-language constructed behind the text - tying together ideas with narratives and counternarratives - tended to be less available to consciousness than the meanings of the words themselves (Strauss \& Feiz, 2014). Yet, I did not embrace the kind of deconstructionism that saw nothing existing outside of discourse. Sometimes people just meant what they said.

The meanings, both hidden and obvious, were systematically arranged using recurring themes as the basis of codes. These codes were used to manually sort discussion notes and transcripts, field notes and secondary materials such as materials from meetings, secondary statistical data and any other information that illuminated itself. Following each interview, the text was transcribed and consolidated with notes from my notebook or that which came from reviewing visual/audio recordings from the interviews. I had covered the walls of my lodgings with large sheets of paper. Any new themes which arose from the interviews were written on the walls. Recurring patterns were linked together until, over a period of nine or ten months, an obvious narrative became clear (to me, if no one else). This narrative is laid out in the following four chapters. 
In adopting an intimacy-geopolitics enquiry through a case-driven approach, my process of analysing discussion transcripts, field notes and film footage was both inductive and iterative. As data was collected and analysed I considered and reflected on emerging themes - emotions, fears, practices and interactions between nodes of REDD+ implementation across multiple scales of implementation. These themes were constantly reviewed as I interrogated the data and brought in opposing perspectives. I did not go to Sungai Lamandau looking for something. The salient themes emerged and shifted as I analysed the text and so I remained uncommited to one specific narrative. I drew on associated literature, and my experiences of other REDD+ activities in Kalimantan and beyond. Moving continually between these sites and the constantly expanding case study material from Sungai Lamandau was a useful way of identifying significant themes that addressed the constantly-shifting research questions whilst speaking to contemporary theory.

Another aspect of 'writing in' that required careful consideration was the role of my language and how it constitutes the very things it names (Butler, 1993). Writing, according to Mansvelt \& Berg (2010: 343), "constructs what we know about our research, but it also speaks powerfully about who we are and where we speak from", forming only a "particular and partial story". Throughout this thesis I have included extensive quotes from participants, in the belief that each participant offered unique ways of narrating REDD+ knowledge formations. I was aware, however, that I had the ultimate control over the writing and dissemination processes. This required a careful approach to my writing, the language I used, and the type of works that were produced (McDowell, 2010). 
Another connected issue is my Bahasa Indonesia skills. I learnt how to read and write formal Bahasa Indonesia, long before becoming fluent in a spoken sense. I therefore had enough confidence to effectively reproduce and represent the thoughts and feelings of the research participants in English. However, I also needed to remain aware of my linguistic limitations. I made mistakes often. On one occasion, 'Do you breastfeed the cows?' was a question I asked to one bemused Sungai Lamandau family (I meant 'Do you milk the cows?'). I ensured these sorts of slip-ups had minimal material consequences for my research findings by repeating responses back to the participant in terms I understood well. By constantly asking respondents how they wished to be quoted, this helped ensure respondents were effectively represented.

Accountability is an important dimension of decolonising research and feminist approaches that seek to address power imbalances (Smith, 1999). Collaborative writing could have helped towards an increased level of accountability. However, due to New Zealand Immigration and Victoria University travel restrictions imposed on foreign researchers, I was unable to reside in Indonesia for longer than twelve months. Though my basic lodgings in Kotawaringin Barat were not particularly conducive to long dedicated periods of writing and data analysis, such conditions would have allowed me to remain immersed, if only partially, in the local context. It would also have allowed me to include the respondents in the write-up process, consulting them on how their actions had been interpreted in relation to the wider project. Collaboration of this sort could have not only given them a degree of control over the material, but also in creating possibilities for further reflection and scrutiny that are important in accountable and trustworthy research praxis (Bradshaw \& Stratford, 2010). 
Nicholls (2009) suggests there has been a noted tendency for researchers to 'hide' within collaborative texts (see also Pain, 2004), and there is therefore a danger that this systematically distorts the power positioning of all who participate in research (Chiu, 2006). Others have noted the irrelevance that writing to academic audiences holds for 'community inquirers' who are more interested in the practical outcomes of the research activity or in the production of material for use by the community involved (Nagar, 2003).

Although I have not been able to collaboratively write-up the research findings with the other participants, I have shared for comment every chapter of this thesis with the REDD+ project implementers at Yayorin, before submitting for publication to academic journals. Research findings will also be communicated and discussed in three other ways: Firstly, a general findings report will be circulated to all participants who indicated they wanted a copy, in both English and Bahasa Indonesia. Ideally these opportunities for reflection, discussion and adjustment of my research would take place before the thesis was submitted. However, I have been constrained by institutional expectations to produce single authorship work and to finish quickly.

Secondly, a short film, currently in development, will be circulated featuring the research participants' multiple perspectives of REDD+ in Sungai Lamandau. This will serve as a useful and relatively more accessible alternative to this thesis and, I hope, will encourage other scholar-activists to assist in making positive change.

And lastly, a workshop entitled Beyond REDD+ will be held in Bogor, West Java and Pangkalanbuun, Central Kalimantan, to discuss findings and invite feedback and further conversations from research participants, academics, activists and other interested parties. As well as providing opportunities for further discussion, the workshop will 
also give me a chance to remember and reflect on my achievements and reconnect with the research participants who I fondly call my friends.

\subsection{CONCLUSIONS}

In adopting a feminist-inspired intimacy-geopolitics approach that rejects the notion of researcher objectivity and claims to universal truths, this thesis does not attempt to uncover a singular 'reality'. Instead the thesis explores how meaning is (re)made and (de)stabilised. In this chapter, I have situated myself as a co-producer of REDD+ knowledge. I have reflected on my position within knowledge production, a process that was outward looking and relevant to the overall activist scholar ambitions of this thesis.

I have also explained the qualitative methods used to gather material, adopting an intimacy-geopolitics approach (see Pain \& Staeheli, 2014) to interviews and observations to elucidate exclusive and gendered spaces of power. In doing so, I discussed the difficulties I had in accessing spaces of decision making, and opening them up to be more accessible for marginalised actors.

Inductive data collection and data analysis reciprocally informed and shaped each other through an emergent iterative process. This process of 'writing the field' served to consolidate my experiences while giving them meaning. The themes that developed through this process inform the construction of the chapters that follow. These chapters make up the thesis' empirical discussion, revealing the pro-capable character of REDD+ as it played out in Sungai Lamandau. 
The following chapter considers the social relations mediating access to the project. In doing so the chapter explores the embodied performances of gender, class and other aspects of social difference affecting certain peoples' abilities to make use of REDD+ benefits, sometimes persuing their desires at other people's expense. 



\section{CHAPTER ANALYSING ACCESS

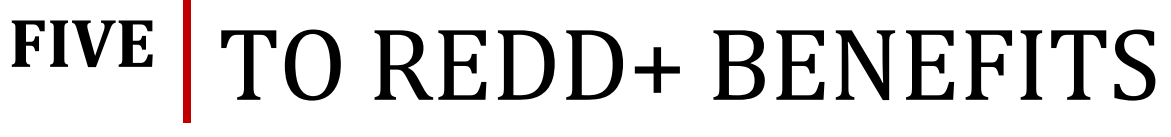

\section{$5.1 \quad$ INTRODUCTION}

There is nothing spontaneous or natural about human desires according to Žižek (2006: 1). "The problem for us is not, Are one's desires satisfied or not? The problem is, How do we know what one desires?" I do not intend to answer this question here in an Epicurean or Aristotelian tradition (see O'Neill, 2006). Instead, this chapter accepts the somewhat defeatist position that people may not know what they really want. Using an intimacy-geopolitics approach to an analysis of resource access, this chapter will attend to the more fruitful questions of, What were the 'REDD+ benefits' available for (or produced by) local actors of Sungai Lamandau? and, What were their means of accessing them?

'Benefit sharing' is an essential part of the workings of REDD+ (Di Gregorio et al., 2013). Whereas benefit sharing was originally understood as referring to the distribution of financial benefits, the concept has come to encompass broader forms of social accountability and responsibility (Luttrell et al., 2013). In the context of REDD+, benefit sharing commonly refers to "the distribution of both the monetary and the nonmonetary benefits generated through the implementation of REDD+ projects" (ibid: 1). 
Through this definition, benefit sharing mechanisms are thought to involve a variety of institutional means, governance structures and instruments for distributing finance and other benefits (Vhugen \& Miner, 2011). According to the UNFCCC, these mechanisms are created through what they refer to as REDD+ 'Policies and Measures' (PAMs). Within this framing are two types of PAMs: 1) compensation for foregone 'opportunity costs' - the expected financial returns from deforesting the land, and 2) incentives to induce positive choices of behaviour (Brown et al., 2008; Peskett et al., 2008). Within this framing benefits are not always related to ones' 'considered desires' (see Sen, 1993). Some are paternalistically imposed, some are left-overs from something else, some are intentional and others are not.

Although the design of benefit sharing mechanisms seems to be high on the political agenda (Luttrell et al., 2013), relatively few studies, if any, have investigated the basic principles and intimate processes underlying benefit sharing arrangements and approaches within sites of project implementation (Nkhata et al., 2012). Rather than seeing REDD+ as a top-down process involving hierarchically-nested governance arrangements, I see it as constituted by a complex interplay of intimately-connected actors and practices across complex networks of implementation. This framing therefore takes into account that while REDD+ may have provided opportunities for international actors to reshape forest governance, it also afforded space for the men and women living in and around Sungai Lamandau to realise their own interests.

In this chapter I explore how the embodied performance of gender, class and other aspects of social difference affected certain peoples' abilities to access these REDD+ benefits. Attention to everyday, seemingly mundane, spatial practices gives insight into how people, through the REDD+ project, (re)produced a particular relationship with 
'others' including their environments (Nightingale, 2011), that were rarely ecologically neutral. I use Ribot and Peluso's (2003: 153) definition of access as "the ability to derive benefits from things" to provide a guiding analytical framework. This approach broadens the classical definition of 'property' as the right to benefit from things, and includes a wider range of social relationships that constrain or enable benefits from REDD+ than rights-based tenure arguments alone. The chapter examines the multiple forms of REDD+ benefits as the 'things' in question. These access processes constitute the material, cultural and political-economic strands within the 'bundles' and 'webs' of powers that configure the REDD+ benefit sharing structure for local actors.

The following section considers the context of REDD+ implementation in Indonesia and the diverse local REDD+ benefits on offer. I discuss the locally-constituted discursive formations of 'equity' and the moral pitfalls of designing a REDD+ benefit sharing arrangement based around 'opportunity cost' compensations - the rewarding of proenvironmental behaviour that would probably have occurred anyway. I then introduce the conceptualisation of access used here to explore how people actively engaged within the Sungai Lamandau REDD+ project. The penultimate section discusses the structural and relational 'bundles of powers', which determine the processes used by local actors to access project benefits. The discussion of these bundles of powers informs the chapter's conclusions. 


\subsection{UNDERSTANDING REDD+ BENEFITS IN INDONESIA}

\subsubsection{MANUFACTURING EQUITY}

REDD+ in Indonesia is likely to produce both winners and losers. Therefore, equitable distribution of benefits has been identified as a key challenge in REDD+ implementation (Ghazoul et al. 2010). This challenge includes issues of 'global' equity, such as the demand by 'developing countries' that 'developed countries' help finance forest mitigation because of their historical responsibility for carbon emissions (Di Gregorio et al., 2013). Issues of 'local' equity are linked to the impacts of REDD+ projects on livelihoods, tenure, and carbon rights, and the need to ensure local participation in decision-making processes (Brown et al., 2008, Cotula \& Mayers, 2009, Okereke \& Dooley, 2010, Larson, 2011).

'Equity' however, is a complex and socially constructed concept. Rather than attempting to establish universal principles of just and equitable behaviour, there is perhaps a more feasible pursuit in understanding who is involved in framing what is 'just' or 'unjust' and how. A number of systematic frameworks have been developed to address this complexity and endorse projects' seemingly equitable outcomes. For example, McDermott et al. (2013) identify three discrete dimensions of equity within REDD+ decision making: i) 'procedural equity' is focused on equal access to project decisionmaking, ii) 'distributive equity' concerns fair distribution of resources, and iii) 'contextual equity', refers to over-all capacity or empowerment. Tools such as 'Free Prior Informed Consent' (FPIC) have also emerged in order to create the required appearance of equity within the international REDD+ instrument. This principle has evolved from the convergence of international human rights agendas and civil society 
critiques of involuntary resettlement for infrastructure and extractive industry projects (Carino and Colchester, 2010; McGee, 2009; Szablowski, 2010).

FPIC is rooted in notions of formally codified property regimes, which affirm the legal rights of persons with property to not become alienated from that property without their consent (Mahanty \& McDermott, 2013). However, FPIC as a perfunctory policy mechanism has also been cast over peoples governed by traditional or 'informal' social systems who frequently lack clear legal identities and property rights (see Whitmore, 2006). A key principle in the workings of FPIC in REDD+ is 'mutual-consideration' achieved through project-based contractual arrangements (Gregersen et al., 2010). Where local people have no clear property rights, their theoretical 'consideration' (their

means of conferring a benefit on the other party) is commonly framed as a sort of ecological ransom, requiring the payment of an 'opportunity cost' - the minimum amount that would need to be paid to forest users not to deforest. This is based on the assumption that a rational economic entity would want to be paid at least as much as the entity gives up by not deforesting (Gregersen et al., 2010). Within this arrangement, FPIC serves to outwardly legitimise the project, guaranteeing local people have both a theoretical incentive to participate and some level of accountability. However, in consenting they are inadvertently painted as illicit actors culpable for the destruction of forests (discussed further in Chapter seven).

\subsubsection{MORAL PITFALLS OF INCENTIVISING FOREST PROTECTION}

Within incentive-based REDD+ projects, non-monetised development-based incentives, such as 'capacity building' and strengthening of 'social capital', (see Mahanty et al., 2013) cause people to move between performative logics and take on new 
subjectivities. These effects have been exemplified within forest governance research generally. For example, in his longitudinal study of forests in northern India, Agrawal uses the term 'environmentality' to refer to "the knowledges, politics, institutions, and subjectivities that come to be linked together with the emergence of the environment as a domain that requires regulation and protection" (Agrawal, 2005: 226). Agrawal's work directs attention to the means through which ecological systems become objects of government, and thereby governable, through calculative practices. These technologies allow forest regulators to incentivise environmentalities and produce particular responses within the ecological systems being managed (McGregor et al., 2015). Agrawal's research explores 'disciplinary environmentalities' - or, practices of government that seek to internalise particular pro-environment norms and values, according to which people would then self-govern. McGregor et al. (2015), building on Fletcher (2010), argue that multiple environmentalities are evident within REDD+ conservation efforts in Indonesia, and suggests these can be used to better understand competing interests around REDD+ forests.

The most relevant for conceptualising REDD+, they argue is 'neoliberal environmentality', which embraces market mechanisms as the primary means of managing populations. Technologies and rationales based on economic growth, costbenefit analysis, and financial incentives are used to encourage and reward proconservation behaviours. As such, the mobilisation of market rationalities represents "an environmental [external] type of intervention instead of the internal subjugation of individuals' characteristic of a disciplinary governmentality" (Fletcher, 2010: 174). In contrast, 'truth environmentalities' are those based on claims about essential cultural and spiritual connections between humans and forests. Local human-forest relations 
and claims to authority may be legitimised through reference to traditional knowledge and practices, and customary claims of forest users. Participation in certain forms of environmental regulation and enforcement generates new conceptions of what constitutes participants' interests (McGregor et al., 2015). Therefore, REDD+ may provide a vehicle through which the environmental imaginaries of local people are communicated and respected by more distant stakeholders. Or, the incentivisation may cause subjects of 'truth environmentality' to take-on a more neo-liberal character.

The principle behind REDD+ project incentives is that they serve to reinforce intrinsically motivated pro-forest behaviour or induce people to follow the good examples of other individuals (Luttrell et al., 2013). However, according to Vollan (2008) an external incentive can lead to a 'crowding-out' of intrinsic motivation. This 'benefit paradox' can be witnessed far beyond carbon forestry. Titmuss (1971), for example, compared the quantity of blood donations from the incentive-based US system with the voluntary arrangements in the UK and elsewhere and found that significantly more blood was donated in the voluntary systems. Similar results were found when communities in the Swiss town of Beznau (Frey \& Oberholzer-Gee, 1997) and Nevada, USA (Kunreuther \& Easterling, 1990) were asked to host a nuclear waste repository. When people were offered monetary compensation they agreed less frequently to the proposal than without compensation (Frey et al., 1996). Another study showed that significantly less people engaged as volunteers when they got small payments for their voluntary work (Vollan, 2008). External incentives can change people's perception of a task or desirable behaviour. Certain kinds of incentives turn motivations of voluntary goodwill into a market-like interaction. In these new monetised arrangements, ideas of 
justice and equity shift from an intrinsic position to being rooted in serviceable claims to things.

\subsubsection{THE DIVERSE IMAGINARIES OF BENEFIT SHARING}

In all but a handful of cases, Indonesia's REDD+ projects have not fitted the definition prescribed to them at the 2007 United Nations climate conference in Bali. The billions of dollars needed to rebalance market forces, which favour deforestation, never came. Since that time, the political dimensions of this 'pure' (market-oriented) REDD+ have been revealed, exhibiting an array of methodological and moral pitfalls. The expansion of markets in ecosystem services has been shown to involve the narrowing down of complex social processes into identifiable and measurable categories, and the reductionism of monetary valuation of those services (Muradian et al., 2010). Critics point to the way privately-funded REDD+ projects mask social relations that underlay processes of production (Kosoy \& Corbera, 2010).

For many Indonesian communities the distinction between development and marketbased approaches to REDD+ have been hard to draw. This blurring is especially common in community-based schemes, in part because payments have frequently been provided in-kind as community development assistance (Milne and Niesten, 2009). As noted by Milne and Adams (2012) the preoccupation of critical scholars with environmental markets and their effects are not fully relevant or helpful for understanding the implications of REDD+ for forest communities, who are rarely included within the carbon market traders' financial benefit sharing frameworks. As Lohmann (2008: 506) highlights, mechanisms like REDD+ are designed to allow for the 
comparison of carbon offsets across cultural and geographical distances. They do not link the 'traders' conceptual, largely electronic universe of 'abstract', simplified, fungible carbon credit numbers" with "the universe of the 'concrete', diverse, particular, highly complex, often obscure 'local' projects that produced them". Even where projects have reduced carbon emissions from deforestation and produced certified carbon credits for sale on international markets, the benefits acquired by local actors remain elusive. Approaches to benefit sharing are rarely tied to performance-based payments exclusively, allowing project implementers to build on existing community development programmes, like the National Programme for Community Empowerment (PNPM), or new ones with links to REDD+ (PROFOR, 2013).

Since national REDD+ policy development began in 2007, carbon storage has not been the primary objective (Indrarto et al., 2012). The process of enticing a diverse mix of project funders required an equally diverse set of promises. There was substantial evidence that values of biodiversity conservation, equity, and sustainable livelihoods were critical to the legitimacy and effectiveness of REDD+ carbon projects (Pistorius et al., 2011). They were therefore better viewed as 'prerequisites' than as 'co-benefits' (Visseren-Haymakers et al., 2012). Furthermore, while non-carbon co-benefits became increasingly important within many of the projects' deliverables, proposals for a REDD+ centralised around carbon payments generated gaps between intentions and reality. Many important learning experiences came from projects like the Kalimantan Forest Carbon Partnership activity, near Kapuas, which included conflicts over land tenure, sovereignty, forest dependency and 'carbon rights' (see Miles, forthcoming). Various actors called for a more integrated REDD+ paradigm encompassing 'three pillars': 
carbon; biodiversity; and community (Pant, 2011). In this paradigm, carbon would be repositioned as a 'bonus' should a viable market for it materialise.

Throughout these calls, significant debate remained about who should benefit from an incentive-based REDD+ mechanism and what the incentives should look like. Many poorly-substantiated claims arose about who 'depends' on forests and the link between forest dependency and poverty alleviation (Belcher, 2012). Increasingly commentators were recognising that underlying who should have (or could have) access to REDD+ benefits were social processes and relations, which connect actors across vast distances between different material realities (Lohmann, 2009). These relations defined who is entitled to the benefits, how much benefits are worth, and which benefits accrue for which actors (Corbera \& Brown, 2010).

Lindhjem et al. (2010) characterised two forms of benefit accrual: The first involved sharing benefits between global, national and local level actors; the second within communities, households and other local actors. These categories are problematic on multiple levels. Scalar formations - which posit the sites of carbon commodity production as fundamentally separate from where they are theoretically traded - are used to justify an inability to distribute benefits equitably across these distances. Furthermore, these categories disguise the messy and inequitable webs of power, painting them instead as neat production lines along which different parties receive what they deserve. The dominant REDD+ scalar formation excludes communities, households and other local actors' from the projects potential direct monetary benefits. These actors are rarely considered 'global' enough for those.

Furthermore, 'community benefits' (e.g. biodiversity conservation; clean water; recreation; livelihoods; etc.) are rarely exclusively 'local'. They are benefits accessible to 
anyone with access to a standing forest. One might also need to consider that nonmonetary benefits such as, 'cultural heritage' and 'recreation', could form the basis for a financially-profitable 'global' eco-tourism venture. Also, some benefits are near impossible to box. For example, 'access to timber' for firewood and construction could be a desirable benefit for forest communities, which simultaneously limit global market access to tradable carbon stocks. Consequently, a potential trade-off exists between different 'global' land-uses for carbon and 'local' livelihood priorities.

Tenure security is another important trade-off. It may guarantee the efforts of certain small-holders against annexation by other parties, but could simultaneously remove land from common ownership and interfere with customary regimes. Despite these risks, tenure security is often envisaged as the primary hurdle in enabling equitable REDD+ benefit distribution (Resosudarmo et al., 2013), which depends upon some kind of socially-acknowledged and supported claims or rights (MacPherson, 1978). Such acknowledgment is normally achieved through formal legal processes, informal custom, or convention (Ribot \& Peluso, 2003). However, my research indicates that formal property claims are often far less important in contests over REDD+ benefits than the more informal means of access.

\subsection{CONCEPTUALISING ACCESS}

An emerging issue in the international push for REDD+ is the way in which property rights around forest carbon are being formed and articulated, especially in relation to underlying land and forest tenure regimes (Takacs, 2009; Sommerville, 2011). A range of theoretical perspectives on 'carbon-rights' have been used in the analysis of forest 
carbon as a new form of property (Milne, 2012). The claiming of compensation for avoided deforestation can be considered as a form of resource struggle, involving negotiations over valuables, interests and knowledge (von Benda-Beckmann et al., 2006), as well as acts of appropriation and persuasion (Busse \& Strang, 2011; Rose 1994). In considering the social processes that constitute these struggles, the fundamental importance of power relations cannot be ignored. These political dynamics of property can be broadly considered as the "processes whereby rights over land and other natural resources are settled and contested" (Sikor \& Lund, 2009: 3). Among these processes, the establishment of legitimate rights and claims through legitimising practices that rely on power and authority is important, but it is not the end of the story.

Beyond this conventional focus on struggles over 'rights', Ribot and Peluso (2003) call for greater attention to 'access'. Inspired by Blaikie's (1985) discussion of 'access qualifications', Ribot \& Peluso's (2003) theory of access, as used here, is a method for identifying the constellations of means, relations, and processes that enable some people or institutions to derive benefits from things. The theory argues that these processes can be rights based (i.e., sanctioned by law, custom, or convention), or structural and relational. As these are mediated by constraints established by the specific political-economic and cultural frames within which access to resources is sought (see Corbera \& Brown, 2010), it is more helpful to consider access as being all possible means by which a person is able to benefit from things whether or not they have 'rights' to them (Lund, 2002; Ribot \& Peluso, 2003; Sikor \& Lund, 2009). Individuals differ in their ability to gain, control, and maintain access to resources, reflecting their capacity to negotiate particular sets of constraining or enabling factors. 
Using this framing, access becomes better thought of as 'a bundle of powers' than a 'bundle of rights' (Ribot \& Peluso, 2003).

Ribot and Peluso (2003) expose the features of tenure that affects people's ability to benefit from things. Access here is more complex than property and is not often readily apparent by examining ownership, or rights to a resource, alone. Access can confer even greater benefits than ownership if, for example, key actors maintain control over a resource through their ability to control access to technology, capital, markets, labour, knowledge, or other critical social relationships that engender cooperation between those who have rights to the resource and those who seek to benefit from such resources. Gilbert and Beckley (1993) and Geisler (1995) have also argued that ownership and control should be analysed separately, given the subtleties of private and public ownership rights in different political contexts. For example, an actor may have formal tenure rights over a forested area to harvest timber, but without ownership of the necessary technology, benefits from that tenure may be limited or completely dependent on market relationships with actors who possess the required technology.

Despite its influence, Ribot \& Peluso's (2003) theory does not have universal support (see Marino \& Ribot, 2012). The appropriate access categories are spatially and temporally contingent and further tailoring is required to help understand the role of local agency. However, it is a robust framework for analysing power relations between distant localities. For example, Corbera and Brown (2010) used Ribot and Peluso's (2003) theory to assess the mechanisms that allow geographically and culturallydistant actors to benefit from carbon offset projects in China, Equador and Mexico. They argued that farmers and rural communities could not derive full benefits from carbon sequestration projects because they lacked key resources (see also Leach, 1999), 
causing a dependence on external 'experts'. In contrast to their study, this one argues that while local actors may possess or use resources to access benefits, it may be more helpful to think through the 'bundles of powers' that they mobilise to access the diverse and, at times, elusive set of benefits within REDD+ projects. Such a conceptualisation recognises the many ways in which power is wielded, yielded and negotiated across vast geographic distances.

None of the access categories I draw upon are distinct, and each form of access enabled, conflicted with, and/or complemented other access processes and resulted in complex social patterns of benefit distribution. Here, the intimacy-geopolitics frame (Pain \& Staeheli, 2014) provides an element of spatial curiousity missing from Ribot and Peluso's (2003) Theory of Access. This spatially curious approach "foregrounds associational as well as instrumental forms of power" and offers an understanding of "power's mediated relationality" in places (Allen, 2004: 19). Furthermore, the intimacygeopolitics frame enables an understanding of how access was mediated by intimate processes that transcended conventional scales of REDD+ implementation - 'national, sub-national and local' (see Angelsen, 2012). Access to markets, for example, connected actors across great distances and relied upon both trans-national finance mechanisms for carbon trading as well as favourable local commodity market conditions, such as rubber and rice. What mediated these market relations were intimate processes friendships, fears, shared histories and spaces of interaction.

Through this exploration of access arrangements across scales, I do not intend to reinforce a scalar ontology informed by a hierarchal spatiality. I do not perceive 'global' markets appearing as a telos in an ongoing process of 'globalisation', reigning supreme over progressive, grassroots, local interventions (see Gibson-Graham, 2002). But, nor do 
I adopt any Friedmanesque notions of 'culturonomic flatness' (Marston et al., 2008), where market access is equitably flattened for the entirety of the world's population. Here, an intimacy-geopolitics analysis of access concerns the links between networked bodies and things, orders and events, doings and sayings across sites of production and exchange. However, the spatial register upon which the transfer of things took place is not understood as a cadastral plan with delineated networks and flows.

Flows are common spatial metaphors to comprehending 'globalisation', but they are just that. As spatial concepts they rely on the presumption that objects and bodies can become "detached from their moorings or nodes and circulate over space", thereby embedding one site into another (Giddens, 1990 in Marston et al., 2008: 50). In this framing, space itself is abolished in a sea of networks and flows. As Schotle (2000: 386) suggests:

'global' relations are social connections in which territorial location, territorial distance and territorial borders do not have a determining influence. In global space 'place' is not territorially fixed, territorial distance is covered in effectively no time, and territorial frontiers present no particular impediment (cited in Marston et al., 2008).

This view of unfettered flows of REDD+ benefits and incentives presents nearly as many problems as the rigid scalar imaginary it promises to overturn. It ignores the specificities of sites of exchange, amputating localised motivations and all their complexities - roping the 'poor', the 'local community' together for the sake of equivalence and commensurability. Accessing REDD+ benefits was in fact dependent on complex intimate social relations intersecting through diverse conservation priorities and individual motivations. The next section explores access to these REDD+ benefits in 
Sungai Lamandau to explore various access categories: markets; capital; knowledge and expertise; social identities and relations, as they were being mobilised by actors within the study site. A general overview of the Sungai Lamandau farmers groups, their livelihoods and ethnic mix, can be revisited in Table 2.1.

\subsection{ACCESSING SUNGAI LAMANDAU'S REDD+ BENEFITS}

\subsubsection{ACCESS TO MARKETS}

Access to both international carbon markets and local commodity markets were key mediating factors shaping access and exclusionary arrangements within the Sungai Lamandau REDD+ project. Carbon benefits were derived from the things that attracted value to the forest's carbon stock, for example, increases in quantities of woody biomass or biodiversity levels. However, many local commodities produced as part of the project's forest restoration efforts, such as rubber, also increased or stabilised in value for some individuals. As observed with other community-based conservation initiatives, financial remuneration was not the main attraction for local actors' involvement (Buscher et al., 2012). Instead, many individuals were engaging in REDD+ as a strategy for protecting their subsistence and market-based livelihoods from external land use threats. As Fattahilla, a member of the all-male Danau Seluluk Jaya group explained to me:

We don't own the forest, I can't understand why people would give us money for trees that we cannot sell [...] I am doing this because the forest is really broken [...] I need the forest for my work and for what it gives me 
[...] If people want to give me money for the trees that I don't use then that is a bonus. Wonderful! (12 October, 2013).

The Clinton Climate Initiative and Yayorin envisioned the Sungai Lamandau project as a community-forestry empowerment project with a potential REDD+ 'bonus'. This bonus would take the form of a direct financial payment to members of the local community groups, to be payable upon the sale of the project's carbon credits, should a buyer materialise.

The international market for large-scale voluntary carbon off-sets could be described as oligopsonistic (or heavily favouring the buyer - see Dormady, 2013). However, due to its community-based approach, project facilitators and funders believed that the Sungai Lamandau project's outputs were significantly more marketable than 'standard' 'corporate' carbon credits. According to a project director from CCI, carbon consultants from Winrock had waived their fee to produce the project's design documents and build a verification standard, in order to be associated with such a socially-virtuous project. However, to date the Sungai Lamandau project has failed to identify a buyer for forecasted carbon credit outputs. Yet, the low global market price of carbon was not the primary cause for preventing the project's market access. It was, rather, a matter of licensing. As a Yayorin programme director informed me:

Carbon credits cannot be sold to anyone unless there is a $\mathrm{HKm}$ land-use license because otherwise we don't own them [...] The license has to be issued by the Bupati (District Regent's office). Other commercial ones could be used instead, but we don't have the money for those and we are not going to pay bribes either (16 July, 2013). 
The ability for a person or organisation to commercially benefit from a resource is often said to depend more on his/her access to a market than whether she/he has rights to it (Tawney, 1978; Ribot, 1998; 2000; de Janvry, et al., 2001). Carbon market access, like other markets, was being controlled in Sungai Lamandau through a multitude of market and state structures and processes. These intersected with practices of exclusion performed by government actors, through policies and systems of licenses and access fees (see also Shipton \& Goheen, 1992).

Just as global market conditions affected access to REDD+ benefits; KoBar's commodity markets also influenced benefit access dynamics. Tanjung Puteri's rubber, which had previously been sold by independent small-holders at volatile prices, started to hold more price-setting clout. Kanjang, a male Sepakat rubber tapper, explained:

Thirty of us from Pendulangan formed a cooperative in 2010, so that all the members can sell the rubber they collect from the REDD+ project [site] to the group for a fixed price. Then the group sells the rubber at the market in Sampit with a Rp500 mark-up, to cover the group's expenses [...] Now no one can tell us lies about how much we should sell [rubber] for. We always get Rp9,500 per kilo: A fair price [...]. They buy from Sepakat or they don't get any rubber (8 August, 2013).

However, as the group's customary lands lay within a protected area, the BKSDA office (the government's nature reserve regulators) limited the number of people able to access the site and therefore restricted how many could benefit. As Iqbal, a BKSDA officer stated: 
There was a thirty-three member maximum on the groups' permit. Now there's a thirty member maximum. It was put in to prevent too many new people who want to use the forest, who might damage the eco-system in the reserve [...] We wouldn't be able to protect the reserve if there's too many coming in and out (14 September 2013).

Participation in the Sepakat rubber collective was essential for accessing land and rubber within the REDD+ project site. However, the village's female members were barred from accessing the rubber collective and therefore could not make a viable livelihood from rubber. This inability to access valuable forest commodities meant women's market access opportunities were much more negligible. Rubber could be stored for months at a time, enabling a secure level of supply throughout the year. Seasonal forest resources considered suitable for women (fish, prawns etc.), with the exception of nipah sugar, could not be stored for long periods without the use of expensive technology. Senja, a member of the Wanita Mandiri women's group told me:

We can sell the kerupuk (fish flour crackers) directly to KORINDO or households, but Citramart [supermarket] only buy them occasionally. Hypermart never have. We use fresh prawns and the prawns can only be caught for a few months a year. We make one or two boxes some weeks and the next we make twenty. Supermarkets don't work like that. They need the same each week or they buy from Thailand or somewhere like that (16 September 2013).

The REDD+ forest was a gendered project. But, it was not the explicit intention of the implementing consortium to deliberately prevent the women's access to markets. Conjugal status loomed large across all pathways to market access. The negotiation of 
Sungai Lamandau's landscape of access and enclosure had the effect of re-citing gendered hetero-normativity.

The situation was a kind of 'patriarchal bargain' (Kandiyoti, 1998) - a performative conjugality, whereby women particularly bartered power and personhood for material security and protection. This took place in contexts where these were essential for survival, and where the cultural contents (and ethics) of conjugality offered a symbolic resource for women in negotiating access to resources within the conjugal partnership. As Jackson (2007: 124) suggests "conjugality also offers possibilities for women [and men] to manipulate discourses of respectability, manage ironic performances of compliance, and engage in cultural inversions and mimicry of the gender order". Whilst Jackson focuses on access to resources within the domestic unit, the Indonesian literature also indicates that every-day conjugal performances sustain respectability in the community (Newberry, 2006), and perform permissible forms of gendered citizenship (Boellstorff, 2005), both of which open up other forms of resource access and entitlement, from the community and from the state that are relevant not just for women (and the production of feminine gendered subjects) but also for men (and the production of masculine gendered subjects) (Elmhirst, 2011). Within this conjugal separation, men were in control of the market value chain. Women lacked the necessary capital.

\subsubsection{FINANCIAL AND CARBON CAPITAL}

Capital is thought of here as finances; formally and informally held assets, such as land and resources; and other things which can be capitalised on in order to derive benefits 
from the REDD+ project. For the local actors of Sungai Lamandau, capital could be categorised into two broad overlapping terms: i) Financial capital - or money; and ii) Carbon capital - the non-monetary resources, which could be put to work in order to create a tradable 'additionality'.

Financing the initial start-up costs of the REDD+ project was provided by external donor bodies and delivered by CCI. However, this was not a clear binary arrangement between the external donor and the local receiver. Aconk for example, Head of the Sepakat group, worked as a paid volunteer on various CCI and Yayorin programmes, including facilitating grant proposals and deciding on expenditures for the REDD+ project. Sixty per cent of Yayorin's staff in fact, were casually paid or unpaid volunteers who lived in a REDD+ project village. The line blurred significantly between community groups, (who would normally be conceived of as the 'local beneficiary') and the 'global benefactor'.

For many community group members, access to forms of finance capital was the main reason for their participation. According to a programme officer from Yayorin:

For most people, the main attraction for joining a community group is the arisan, [rotating communal savings and loans schemes] especially in the women's groups because they are in charge of the money for the house (21 June, 2013).

These arisan are common in most rural areas across Indonesia (see Hospes, 1992). The scheme was adopted by all ten community groups. The Karananya women's group of Cabe Rawat, met formally each month, during the nine-month period of research, sometimes solely to discuss the arisan. The scheme was very simple - each month, group members paid an instalment into a communal pot and an undian (lottery) 
decided the total's recipient. The process was repeated each month until each member had taken the winnings. Although the women's schemes were established by and for their members, it has been argued that, "continued reliance on [arisan schemes] is one means of perpetuating the marginalisation of women's economic activities" (Berger, 1989: 1024). According to Hospes (1992), the arisan can only be accessed at certain times, by certain actors, for certain purposes and constitutes an inefficient mobiliser of savings. However, Yuwida, a member of the Wanita Mandiri women's group in Pendulangan, explained:

We're not only having meetings and sharing our own money around, we work every week maintaining nipah trees for sugar and many of us take turns making kerupuk to sell [...] We pool together the profits which we loan out again to the members. [...] Now we have our own money which we make from our own land.

As well as assisting group members' access to capital to meet domestic requirements, these ventures had knock-on benefits: Monthly gotong royong (voluntary group work) activities commenced to restore the nipah's degraded mangrove eco-system around the village providing various environmental services ${ }^{19}$. The women's claim to the land had built up through servicing the riverine eco-system, the improvement of which enabled the women to gain social recognition of property rights, as well as associated carbon benefits.

In general though, women within the REDD+ project were not demanding land, or rather, not demanding a radical shift to situated conjugal "rules of complementarity"

\footnotetext{
${ }^{19}$ Nipah acts as a soil acidity regulator. It reduces salt-water inundation to arable land and provides an important breeding habitat for various fish and birds.
} 
(Karim, 1995: 16) between themselves and their husbands. Yet, the question remained: Did the absence of a widespread demand indicate the absence of a need? The argument that women's land rights do not deserve policy attention, since rural women themselves are not demanding this (see Narayan et al., 2000) is troubling because it assumes that voiced demand (or lack of) is a sufficient indicator of needs and preferences. This is not to deny the critical importance of asking the deprived their priorities. But, it is equally critical to recognise that the deprived may have incomplete information about all options, and thus fail to mention those that seem out-of-reach (Agarwal, 2003). They might shape what they reveal about their livelihood priorities according to how an interview is conducted. Or they might adapt their priorities to what they see as attainable (Nausbaum, 2000; Sunstein, 1993).

The conjugal partnership was an essential part of the informal land-ownership regime, where tenure security depended on continual occupation and use of land to avoid appearing available to others. Men's ability to explore REDD+ opportunities was made possible by the continued labour investments of women on existing family plots. Women were able to maintain the legitimacy of the family's resource access, whilst at the same time, they provided a material basis and safety-net of entitlement (see also Elmhirst, 2011) for the men's more risky but potentially rewarding REDD+ ventures.

Access to benefits derived through the commodification of forest carbon was mediated by an individual or group's ability to capitalise on natural assets. This 'carbon capital' included the project site's orangutans, which were rarely considered desirable neighbours in communities with high forest cover, due to their perceived aggressive 
nature ${ }^{20}$. As Siska, a nipah sugar farmer from the Wanita Mandiri women's group told me:

I see an orangutan in the nipah forests once or twice per month, and I usually just run away [...]. I heard that a housewife in Pendulangan was attacked in her home by one [...] They say it's because of the palm oil opening up the forest, but I think they just come for our cooking ( 9 October 2013).

With the implementation of the REDD+ project, Yayorin had implemented a humanorangutan conflict mitigation programme and, according to Yayorin project officer, Ade, community members had begun to tolerate the release of orangutans into near-by forests due to the perceived increase in access to REDD+ project benefits. The release of four large Esturine Crocodiles was also unanimously accepted at a Pelangi KoBar Bersatu group meeting in September 2013. The Yayorin director once stated in a presentation to the PKB farmers groups:

Releasing endangered species increases the conservation value of the forest [...] So the carbon that we will sell attracts a premium if we can prove to the CCBA (carbon certification body) that we protect the biodiversity and protect the carbon at the same time [...] If a buyer has a choice between Rimba Raya credits, Danau Siawan Belida credits or ours, they'll buy ours, because we have the orangutans and the hornbills (1 August 2013).

\footnotetext{
${ }^{20}$ According to a health officer at the district health authority (Dinas Kesehatan Kotawaringin Barat), no injuries caused by an orangutan attack had ever been recorded at any district hospital (Puskesmas).
} 
Allowing the release of these species enabled the group members to access further carbon benefits. Producing carbon credits while improving biodiversity values would enable the project to receive CCBA 'gold-standard' certification and would allow the consortium to sell REDD+ carbon credits at a premium price. But of course, these carbon benefits were only available to those able to join a cooperative or those with the knowledge and expertise to benefit by other means.

\subsubsection{KNOWLEDGE AND EXPERTISE}

Knowledge of what the REDD+ project was and the regulation of how it was understood, were used as attempts to control access to potential benefits. 'Technical' knowledge, in the form of a set of expertise to make forests marketable for their carbon values, also formed a useful tool for accessing project benefits, opening doors to project benefits for certain individuals. Four members of the PKB community group had taken part in forest carbon and biodiversity monitoring training in the provincial capital, Palangkaraya. The training, sponsored by large development NGO, the World Wildlife Fund (WWF), aimed to provide group representatives with skills in GPS, basic GIS mapping and other environmental monitoring software packages.

Yayorin volunteers were also training to use camera traps, owned and operated by orangutan conservation NGOs, OFI and OFUK, used to calculate the conservation value of the project site. This technological know-how was allowing areas damaged by fire, illicit logging or other causes of carbon leakage, to be effectively inventoried and remediated thus enabling access to additional carbon benefits (see Figure 5.1). 
Figure 5.1: Yayorin volunteers and community group members at a Community-Based Forest Monitoring Training session (November, 2013)

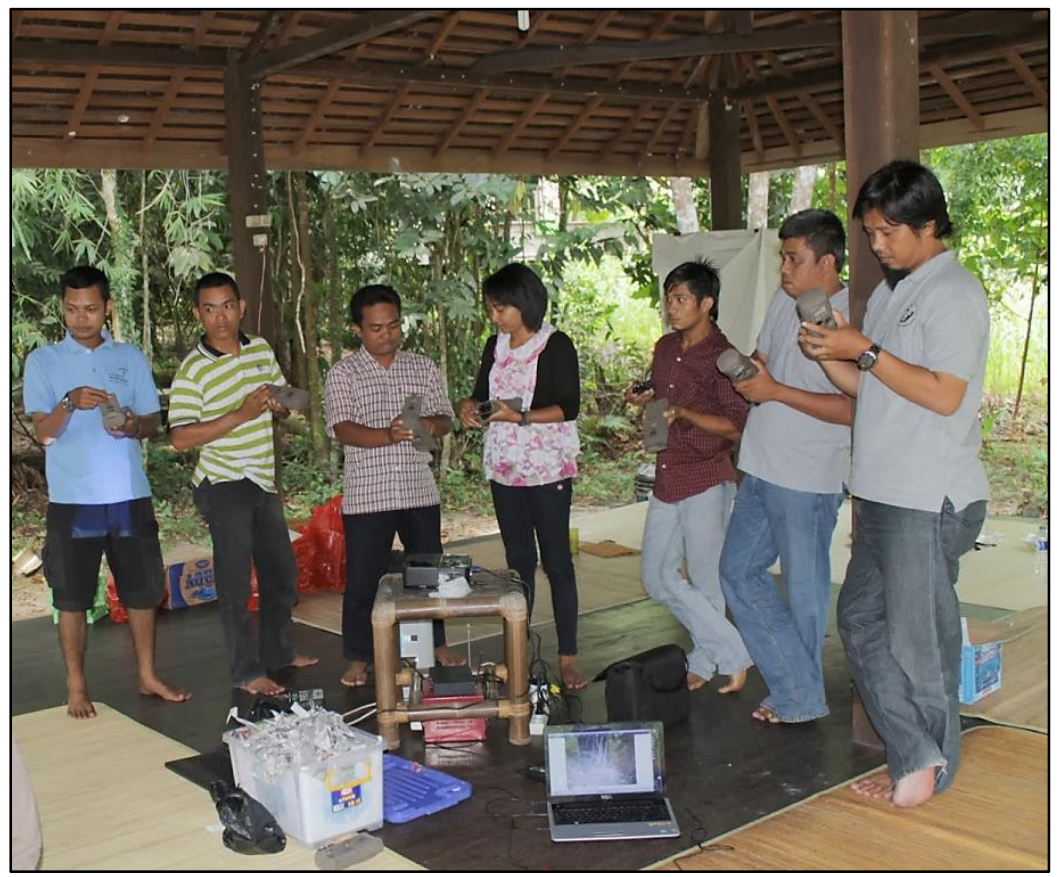

However, knowledge of REDD+ was diverse and varied across networks of implementation. This point was reinforced when a project advisor from Winrock observed:

Carbon is just one layer of investment capital to fund what [the project implementers] were going to do anyway. [...] These are billion dollar activities, so costs for private ventures will always be covered first before communities get any benefits. [...] These communities don't have recognised rights to the carbon anyway or compensation.

REDD+, when conceived in this way, was difficult to see within the community groups of Sungai Lamandau. The project was described by Yusuf, a male member of the Sei Gandis group as: 
A lake, not a pyramid - we will get out what we put in. [...] If I want to work I will put my name down and the group will agree on the roster. Then the people who work will get paid. It has to be fair or people will break the rules (14 August 2013).

The discursive regime to negotiate the meaning of REDD+ in the Sungai Lamandau context was complex. Outside 'experts' were influential in this regime. However, they failed to dominate it entirely. The World Agroforestry Centre (ICRAF), who provided initial recommendations to the project implementing consortium, recommended that, "Planting oil palm on degraded, non-peat soils outside the buffer area can absorb labour and reduce the pressure on relatively carbon-rich land-cover types" (ICRAF, 2010:1). However, community groups, at a PKB meeting in May, 2013, later rejected this recommendation as inappropriate, favouring the introduction of managed fish ponds on underused rice fields, for which support was available through the REDD+ project fund. Sualtan, a male fisherman from Karananya, commented:

Prices for fish at the market are higher than they have ever been because there's nothing left in the river. It's toxic like acid and hot because of the palm oil and the mines up the river. Why would we want to make it worse!? [...] Building fish ponds is cheap and we can do it ourselves (19 July 2013).

Throughout the Sungai Lamandau villages, oil palm was blamed for snake and orangutan attacks (species which had originally inhabited forests taken over by smallholder plots), water shortages, increased soil acidity and climate change. For Terantang in particular, planting more than a few 'greedy plants' as one male rice 
farmer in Terantang described them, could lead to ostracism (Akim - 12 November 2013).

There exists a clear juxtaposition of two very different expressions of culture-nature relationships here (see also Eilenberg, 2015). The first, belonging to ICRAF, could be interpreted as through what Sullivan (2010: 113) refers to as an 'imperial ecology' constituted by the "ideational transformation of 'the environment' into new commodity fictions or 'ecosystem services'“. The second, belonging to Pak Suantan and many other Sungai Lamandau villagers, is a more 'immanent ecology' in which the human - nonhuman nexus is more explicitly experienced as "one of intersubjective intensities and shared sentience" (ibid). I do not refer to this as 'indigenous' knowledge (see Fletcher, 2010), mainly because many of Sungai Lamandau's women and men did not identify themselves as such. The designation also perpetuates the exclusivity of an imminent ecology that might usefully be expanded far beyond formally recognised indigenous people.

Despite many of the groups' lack of formally recognised 'indigeneity', many farmers within these groups operated alternative resource use regimes - a 'post-conservation' perspective (Igoe, 2004) more concerned with social and environmental justice than biodiversity preservation. The REDD+ knowledge instituted through ICRAF's recommendations, which worked to foster the (re)production of neo-liberal environmentalities, found resistance in the situated truth environmentalities fostered in a different kind of REDD+ knowledge.

\subsubsection{SOCIAL IDENTITY AND RELATIONS}


For many group members, ability to access project benefits was determined not by what they knew, but who they knew. Knowledge concerning formal governance structures were strongly linked with access to authority (either being in a position of authority or connected to someone who was), which in turn shaped the individual's ability to benefit from resources. Group members, who saw themselves as having customary access rights within the project site, were often tolerated by local government officials on certain conditions. Ilan, the head of the men's Sei Gandis rubber collective explained to me once:

I know everyone in the Dinas office. I built their houses. We're friends. [...] They put my name on the license and now the group can use the land for their cows (29 August 2013).

Ilan's position was becoming solidified as the group's Ketua Umum (day-to-day leader) because he had access to officials at the local Dinas Peternakan (government livestock and animal husbandry office). The group's use of land on the edge of a vacant concession was tolerated as long as he was formally accountable as the elected Ketua Umum.

In many cases the chain of authority was less simple. Legal and customary authorities were competing and conflicting in the sense of having overlapping jurisdictions. For example, having an expired entry permit for accessing customary lands within the protected areas of Sungai Bulu was not an issue for many Pendulangan residents who were well connected with forest guards. These guards were more inclined to recognise customary rights over formal legal processes, where a strong social or family connection existed. As Jangi, a male Sepakat rubber-tapper told me: 
The guards [at the tributary gate] are my brothers. You (the author) don't even have to show your SEMAKSI (park entry permit) when you're with me, but they will check other people. [...] I bring supplies and fuel over for their generator from the village. I don't have a generator at my place so we (the guards and Jangi) hang-out together at the gate house when it gets dark (25 October 2013).

Having a social connection to influential people in terms of age, ethnicity, gender, indigeneity, religion, language, livelihood, place of birth, and many other social identity factors, effected which doors to specific REDD+ benefits were open or closed. The ability of members to form, or at least join, a community group was a critical strand in the bundle of powers to access REDD+ benefits. However, this depended on a culture of reciprocity, friendship, trust and mutual dependence between members. In turn, the formation of community groups strengthened economically-based ties, in addition to other identity-based relationships. Yintin, a male farm labourer in Terantang, stated:

I join-in the [Danau Seluluk Jaya] group meetings even though I live and work in Terantang in the rice fields [...] I don't speak Javanese, and I don't pray anymore and that's what they do at meetings [...]. I feel more at home here [in the group]. It's located twenty-Km away from my home, but that's fine [...]. I can't attend all the meetings (9 July 2013).

The intersectionality of ethnicity, gender, class, and potential access to a REDD+ farmers' group was starkly highlighted by the normative restrictions placed on women in the Javanese transmigrant village of Terantang. Many of the married women from landed families were members of a local prayer group. The prayer group was informally organised, but based on the PKK (Pembinaan Kesejahteraan Keluarga, or Family Welfare 
Guidance) model, which has produced and reinforced ideologies aimed generally at spatially and socially domesticating women (Silvey, 2004; Brenner, 1998; Shiraishi, 1997). I asked Sunita, a member of the prayer group, why Terantang's women lacked a REDD+ farmers group. She responded:

We don't need a farmer's group. The women support the men's REDD+ group. [...] We make cakes and sugar cane juice for them and everyone eats together after the gotong royong. [The prayer group] prepares all the food (12 November 2013).

Women from landless families within the transmigrant community had not joined the prayer group, mainly due to conflicting work commitments. Yuli, a female labourer, explained:

We are women who use hoes, not washing machines. No, we don't join the prayer group. [...] My husband is a member of the Tani Sejati group already. We will start a group for the ladies. That is, when the project is moving properly. Some of the ladies work on Sundays already at the Karananya nursery with the Danau Seluluk Jaya group. I don't have the time for that (18 November 2013).

Where some groups, like Danau Seluluk Jaya, were very open to new members of various social categories, and did not make exclusive benefit claims based on 'indigeneity' or religion, some had stricter requirements. Sepakat members, for instance, had strategically constituted themselves as 'suku asli' (indigenous people). As Irfan, the group's head explained, "We are protecting the forests from loggers and companies because they are ours. That is our responsibility" (25 June 2013). As argued 
elsewhere by Li (2010: 385), Sepakat members were finding themselves "caught up in capitalist processes [...] using a concept of indigeneity as a defensive response". In doing so they asserted their practices as 'customary law,' their land as 'tribal land' in order to unite people within processes of shared struggle.

Though the ethnic Malay of Sepakat were situating themselves in this way, they were less well supported than the more recognised 'Indigenous' Dayak groups with their provincial Dayak power structures or the international and national NGOs with interests in their empowerment. The Alliance for Indigenous People of the Archipelago (AMAN) for example, is a well-funded national advocacy group representing the rights of indigenous communities across Indonesia. However, in Central Kalimantan, where the organisation has played a significant role in mapping adat (customary) land, the organisation was being perceived by many of the ethnic Malay groups as an explicitly 'Dayak' support network. As Alam, a male Sepakat group member, told me:

We have been here for as long as [the Dayaks]. We have our language and customs [...]. We are an original tribe. [...] AMAN helps the people who are already rich businessmen with their own land [...]. [The Dayaks] are very clever and we're just honest, but we get nothing. We're an original tribe too! (2 November, 2013).

The REDD+ project gave some group members an opportunity to reform prevailing power structures within their communities. In the past, the village's elected leader (or Kepala Desa), was able to access all the benefits associated with being in a position of high social standing. The Kepala Desa had access to government officials and was endowed with certain strategic decision making powers affecting the village. However, 
being in a privileged position of authority was not enough to secure access to the project's benefits. One male group member explained the story:

We in Sepakat wouldn't let [the Kepala Desa] join the group. He had no business or connection. So he got angry and started a fake 'registration fee' for new members of around Rp100,000 to finance 'monitoring'. We found out he'd done this so we told BKSDA. They fined [the Kepala Desa] and he had to give back all the money (14 July 2013).

As members were required to hold a livelihood connection with the group's activities, village and sub-village heads could be excluded, or at least held back from decisionmaking positions if that was thought to be in the interests of the group's members. The REDD+ project, at least in the cases just mentioned, had been 'twisted' from a purely carbon-forestry idea to a potential means to transmute the prevailing class system and provide platforms for mobilising against prevailing power structures. But, the extent to which the project as a whole could be acknowledged as a means to realise social justice remains questionable. I will explore this issue further in the following chapter.

\subsection{CONCLUSIONS}

Using an intimacy-geopolitics frame (Pain \& Staeheli, 2014) this chapter has foregrounded the quiet politics of the REDD+ project, demonstrating how interpersonal relationships were wrapped together in wider geopolitics (see also Askins, 2014). In doing so the findings show how access controls were interwoven across multiple sites and scales of project implementation. This intimacy-geopolitics frame complimented Ribot and Peluso's (2003) Theory of Access. The frame provided 'spatial curiosity' (see 
Allen, 2004) to show how intersecting spatial relations, interactions and practices gave rise to nuanced benefit distributions. The approach therefore accounted for power's mediated relationality in places.

By thinking through Ribot and Peluso's (2003) 'bundles of powers', which determined the processes used to access project benefits, the chapter showed how some local actors were able to benefit from the REDD+ project, whether or not they had formal rights to them. Local actors' ability to access any benefit was dependent on intimate relations and practices - being able to coalesce around shared interests, and form REDD+ farmer's groups or women's groups. This coalescence was contingent upon socialidentity factors, enabling access and controlling incentives for participation. These collaborations also provided platforms for asserting the claims of certain individuals. Some actors were able to join local NGOs and gain new skills as volunteers or paid staff. Some used their new knowledge of REDD+ to reshuffle local power structures, while elsewhere the REDD+ project had a cementing effect on pre-existing paternalisms.

Power, authority and social relations within the REDD+ project were essential components in understanding how and why certain actors were winning in their pursuit of project benefits while others lost out. Furthermore, land tenure and property rights were dependent on legitimising claims and what constituted a good claim was dependent on the recognition of de facto powers and authority. Some actors in Sungai Lamandau were pursuing their claims for REDD+ benefits, in part through responses to complex histories of perceived social and environmental injustice - reactions to government sponsored appropriations, resettlement schemes or large-scale corporate agricultural projects. 
It was not surprising that local actors lacked the market-access, capital and expertise to commercialise Sungai Lamandau's forest carbon and thus required the assistance of project developers and third parties to plan project activities and validate carbon credits. Local knowledge concerning what REDD+ is, in the Sungai Lamandau context, differed significantly from external conceptions. By thinking of all Kalimantan smallholders as economically rational, pro-oil palm actors, powerful international consultants and other actors attempt universalising categories and promote their interventions in the name of environmental protection. Instead, Sungai Lamandau's community groups were enforcing their own knowledge, using that for political effect. Individuals' knowledge claims around the potential incentives also varied throughout Sungai Lamandau's villages and interest groups. These struggles over knowledge and access to benefits have been understood as embedded within broader political struggles over identities - religious, ethnic, racialised, or gendered.

Understanding how diverse strategies emerge and interact to produce new forms of place-based environmental governance is important if REDD+ is to evolve in socially and environmentally just ways (McGregor et al., 2015). In Sungai Lamandau REDD+ was made possible by globalising political economies; patterns of investment; movements of capital, and knowledges; but was also driven by the agency of Sungai Lamandau's farmers and the particularities of their situated histories and geographies. The chapter therefore, has illustrated the entanglements and indivisibility of proximate and distant spaces within REDD+ benefit sharing arrangements.

Yet, one should not assume that equitable distribution of benefits between actors (proximate or distant) as normal responses (or indeed possible). In Sungai Lamandau, 
some people sought to engage with REDD+ access controls on their own terms, sometimes with the effect of accelerating intimate processes of exclusion. 


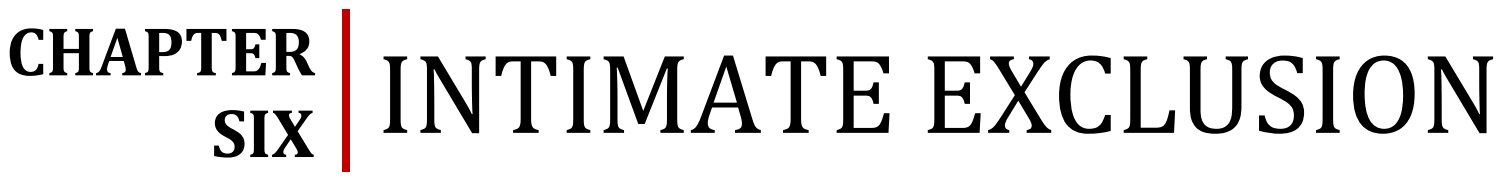

\subsection{INTRODUCTION}

Polanyi (1944: 178) wrote in The Great Transformation that land is "an element of nature inextricably interwoven with man's [sic] institutions. To isolate it and form a market for it was perhaps the weirdest of all the undertakings of our ancestors". He continued noting that:

In the field of modern colonization [...] the true significance of such a venture becomes manifest. Whether the colonist needs land as a site for the sake of the wealth buried in it, or whether he [sic] merely wishes to constrain the native to produce a surplus of food and raw materials, is often irrelevant; nor does it make much difference whether the native works under the direct supervision of the colonist or only under some form of indirect compulsion, for in every and any case the social and cultural system of native life must first be shattered (ibid).

Despite its supposed 'inclusivity', a green economy requires both the enclosure of land and cheap (if not free) labour in order to produce exchangeable carbon commodities with efficiency and effectiveness (Angelsen et al., 2009; Sunderlin et al., 2009). In 
Indonesia, REDD+ is being presented as an effective and cost-efficient option for mitigating climate change (Neilsen, 2013). However, because REDD+ is a market mechanism aimed at achieving carbon sequestration from forests at the lowest possible cost, equity outcomes are not an integral part of its design (Di Gregorio et al., 2013). Assembling REDD+ land as a resource involves attracting and creating a diversity of subjectivities - villagers, scientists, investors, legal experts and government officials. Such actors use distinct ontologies (ideas for what land can or should do), and affordances (ideas for how humans should interact with land) (Li, 2014a). In paying for the development of these initiatives, investors are seeking to institutionalise REDD+ rationalities in the forestry sector, and encourage forest practices and subjectivities oriented towards carbon conservation (McGregor et al., 2015). Amending traditional ontologies and perceived affordances of land allows barriers to dispossession and other social protections to be removed and replaced with a more market-based calculus.

Creating a REDD+ project's variegated terrain of winners and losers is often considered a 'global' pursuit (Corbera \& Schroeder, 2011), where powerful capital interests exert access controls over forest resources transnationally. As well as helping to expose this feature of the green economy, this chapter argues that the push for REDD+ enables endogenous processes of 'everyday' accumulation and dispossession, attracting neoliberal subjects, but also creating them through neo-liberalising discourses (Fletcher, 2013). In making this argument the chapter explores the diverse array of ways individuals have both been excluded, and have excluded others, from land and the REDD+ benefits wrapped up in it. Hall et al. (2011: 7) define 'exclusion' as the "ways in which people are prevented from benefiting from things". This is a reversal of the definition of access as "the ability to benefit from things" used in Ribot and Peluso's 
(2003: 153) A Theory of Access. The conceptualisation used here however, does not simply take exclusion as something negative, counter posed with the positive idea of 'inclusion', but rather as something inevitable. The chapter focuses on 'intimate exclusions', which Hall et al. (2011: 145-146) define as the “'everyday' processes of accumulation and dispossession among villagers".

The following section considers the legitimising discourses enabling new enclosures produced through REDD+ and the unlikely constellation of actors working to produce them. I discuss the environmental green agendas at the core of local 'grabs' for land and the inevitable exclusions brought about through the formalisation of private property rights, as well as the attempts to promote a certain 'inclusivity'. The penultimate section discusses the powers of intimate exclusion used across the constellation of REDD+ actors to secure access to REDD+ benefits for themselves. These discussions inform the chapter's conclusion.

\subsection{UNDERSTANDING THE NEW ENCLOSURES WITHIN INDONESIA'S 'POLITICAL FOREST’}

\subsubsection{REDD+ FOR AN 'INCLUSIVE’ GREEN ECONOMY?}

REDD+ has brought together new coalitions and alliances between what might once have seemed unlikely bedfellows: businesses and NGOs; conservationists and mining companies; ecotourism outfits and the military, to mention but a few (Fairhead et al., 2012; Corson \& MacDonald, 2012; Ojeda, 2012) (see Figure 6.1). 


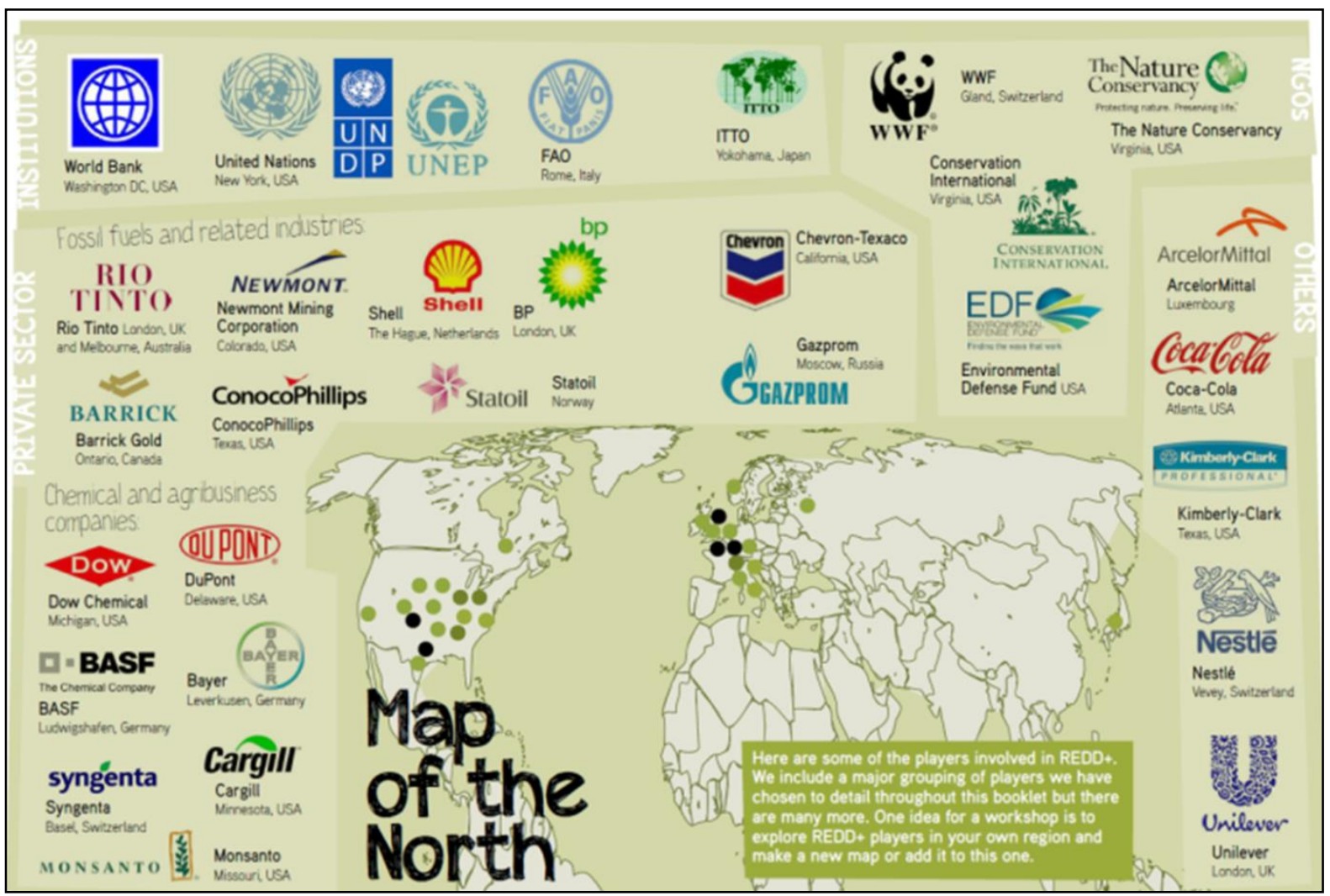

Proponents of neoliberal approaches to environmental management maintain that pricing 'nature' and its services allows markets to internalise environmental externalities (McGregor, et al., 2014). It is also argued that market-based approaches can assist in clarifying private property rights, mobilising private sector resources and expertise for conservation. In other words, markets for environmental goods and services could drive 'green-growth' in a 'green economy' (UNEP, 2012). REDD+ has been promoted as the catalyst for a green economy, while at the same time progress towards a green economy stimulates REDD+ investments and makes them more secure; thus there is a mutually reinforcing relationship (McKenzie, 2014).

According to the UNEP (2012: 8), "in its simplest expression, a green economy can be thought of as one which is low carbon, resource efficient and socially inclusive". Yet, just 
like REDD+ 'equity' (discussed in the previous chapter), REDD+ 'inclusivity' is also a complex and socially constructed concept. Unlike Frierian notions of 'participation', 'inclusivity' has not ascended to the pantheon of development buzzwords (Leal, 2007). It is devoid of any substantial spirit. But, as a central pillar to the UN's green economy paradigm, the concept requires troubling - how and why are different players across a broad constellation of actors 'including', or being 'included', within Indonesia's REDD+ framework? Rather than attempting to work out how REDD+ projects, as part of this green economy framework, are made 'inclusive', I instead argue that 'social inclusivity' is a means to legitimise a globalised construction of Indonesia's forests. Within this broad framing, powerful capitalist interests are enabled to implement access controls over carbon commodities and other forest resources between distant localities. The agency of forest users in such a formation is restricted, as a benevolent and 'global' green economy is tasked with dishing-out benefits appropriately.

Within debates over the political ecologies of REDD+ in Indonesia, the phrase 'political forest' has been coined to capture this particular constellation of territorialised power (Elmhirst, 2011). Expressed through ideas, practices and institutions, spatial limits are placed upon certain peoples' ability to access and utilise forested land, providing recognition and legitimacy to some, whilst excluding and criminalising others (Peluso \& Vandergeest, 2001). Yet, 'on the ground', forest boundaries are far more permeable than they appear on maps and planning documents. These forest boundaries, like any other spaces, are contested zones where local agency and resistance through regimes of access are exercised not as side-effects, but as critical gears within the REDD+ mechanism. Tsing (2005: xi; see also Nel, 2014) refers to these spaces as "the zones of awkward engagement" - spaces where things mean something different across a divide 
"even as people agree to speak". These zones of cultural friction are transient; they arise out of encounters and interactions, reappearing in new places with changing events.

Within the political forest, various conservation and development projects, linking actors across vast distances, have been designed to facilitate resource extraction and rationalise land use (Elmhirst, 2011); transfer populations from one place to another (Lund, 2011); or divide farm from forest (Li, 2007). In the same vein, REDD+ can be seen as a 'spatial fix' (Harvey, 2003), organising costly emission reductions through a geographic expansion of markets providing cheaper production alternatives within relatively socially deprived spaces, as well as creative opportunities for capital investment. The use of this spatial fix to find cheap emissions reductions parallels other ways that capital avoids economic crises and enlists the marginalised in the pursuit of further accumulation, as forests are incorporated as new revenue streams (Harvey, 2005; Nel, 2014).

The legitimising discourses within these accumulation practices enable the green economy's spatial fix, which then produces new enclosures of land through REDD+ project formations. These are examples of the phenomenon captured within the term 'Green Grabbing' (Vidal, 2008) - the appropriation of land and resources for environmental ends. This form of appropriation implies the transfer of ownership, use rights and control over resources that were once publicly or privately owned - or not even the subject of ownership - from the poor (or everyone including the poor) into the hands of the powerful (Fairhead et al., 2012). However, it is not the same as a simple, agreed transfer of ownership or sale. It is an emotive term because it involves a degree of injustice. It is also a central characteristic to processes of accumulation and dispossession (Harvey, 2005). This could look like simple capital accumulation, in which 
surplus profits accruing to capital are reinvested, increasing capital and the concentration of its ownership. Or it could be primitive accumulation, where a more publicly owned 'nature' is enclosed into private ownership. This form of grabbing entails the expulsion of existing claimants (or the attenuation or access rights) producing a dispossessed agrarian proletariat separated from land and nature, releasing resources for private capital (DeAngelis, 2001; Glassman, 2006; Kelly, 2011 Fairhead et al., 2012).

\subsubsection{GREEN GRABS \& REDD GRABS}

Green grabbing can be understood as part of an on-going lively debate on 'land grabbing' more generally, which highlights instances where 'green' credentials are called upon to justify appropriations of land for food, fuel or capital speculation (Borras et al., 2012; Fairhead et al., 2012). All REDD+ projects constitute an enclosure (or reenclosure) of land for conservation purposes motivated by efforts to attain a kind of 'common good', through poverty alleviation and sustainable development discourses. There is therefore significant overlap between market-based enclosures for food and/or fuel and those designed primarily to protect REDD+ forests, wherein the same virtuous characteristics operate with similar, if not the same, will to improve (Li, 2007).

As Hall (2013) explains, production of boom crops and protection of forests are often considered the inverse of one other. Yet, both projects of conservation and production involve a transnational push for influence in some of the most day-to-day aspects of local people's relationship with land and each other. Pearce (2012) also argues in his book, The Land Grabbers that many corporate investors claim to aspire only to protect 
fragile eco-systems from the unscrupulous interests of those who seek to pillage land of its resources and displace its vulnerable communities. They often claim their actions benefit not just investors, but host governments, landholders and communities and can contribute to 'feeding the world' and conserving biodiversity. However, Pearce (2012) also argues that this land is usually pulled out from under the world's hungriest people.

REDD+, as part of a wider green grab narrative in Indonesia, is changing people's relationships with land through violent enclosures (Sullivan, 2010). Land, like any resource, is not a 'natural thing'. All resources are, as Bridge (2009) explains, 'cultural appraisals', of their utility and value. These things become resources when they become associated with a complex set of social understandings about wealth, beauty, love, control, commitment, power, etc. For many things we become forgetful in our appraisals, but land, as Thompson (1963: 213) argued, “always carries associations of status, security, rights - more profound than the value of its crop". To turn land into a resource requires regimes of exclusion that distinguish legitimate from illegitimate uses and users through devices such as fences, title deeds, laws, zones, regulations, landmarks and place-specific story-lines (Li, 2014a). To isolate it and convert it into commensurable units for purposes of incentivising labour to service tradable carbon stocks, inevitably brings in far-reaching consequences.

This particular brand of violence draws distinct parallels with the violence that is central to processes of state formation (Grajales, 2011) and the legal frameworks that sustain governmental control (Scott, 2009). Through political technologies, institutions, and projects of tenure reform, global actors attempt to convey a message that marketsociety must be defended against its enemies, or those 'Others' who would threaten its ostensibly peaceful order (Spinger, 2015). As the violence of law is both sanctioned and 
mystified through such technological and institutional procedures, particular political rationalities are (trans)formed (Foucault, 1988). The supposed 'rightness of property' becomes ingrained in the political forest, and as with all historical forms of enclosure, private property regimes accordingly help to create and sustain a discrete 'geo-body' (Spinger, 2015) constructed not only by technocratic regimes for managing land, but also through a bio-political project that geographically bounds subjectivities to capitalism (Malhi, 2011).

What is needed is an appreciation of an underpinning principle of capitalism itself, namely accumulation by dispossession, which is always by necessity violent (Wood, 2002; Springer, 2015). In Indonesia, REDD+ activities all entailed the enclosure of land for conservation purposes, with the potential to dispossess certain actors. These are generally imagined as 'top-down' processes, conducted by governments and corporations to the detriment of smallholders. However, within the political forest smallholders at times vigorously engage in enclosure (Hall et al., 2011), instituting processes of accumulation by dispossession 'from below' (Li, 2007), often at times, through discourses of common-property. As Hall et al. (2011) point out; smallholders do not always engage in community-orientated defence of 'the commons' and often seek land in the form of private property for themselves resulting in 'micro-enclosures' for personal gain (Tubtim \& Hirsch, 2004; Astuti \& McGregor, 2015). The REDD-Grab need not therefore be a 'global' one. 


\subsubsection{CARBON ENCLOSURES FOR 'COMMUNITY FORESTS'}

Access to land is not something that can easily be allocated to a 'community' as a REDD+ 'benefit'. Where control of land is a primary REDD+ benefit, competition will at times be fierce. As people use the powers at their disposal to lay claim to newly-valuable REDD+ land, a slow fragmentation of the commons may ensue, with inequitable results. Yet, 'community forests' (Hutan Kemasyarakatan or HKM/HD), based on collective action, are sometimes given a tint of utopia - as inherently more equitable than other regimes (Krishna, 2004). Equity, as discussed in the previous chapter, is a highly contingent characteristic and depends on the nature of interaction within private property arrangements (see Quiggin, 1993; Tubtim \& Hirsch, 2004). Forest conservation project implementers' attention to formal incentive arrangements often prove misplaced, overlooking the symbolic meanings and functions of common property in the wider production of locally inclusive social relations (Mosse, 1997). Access to benefits in one village can be associated with exclusion of neighbouring villages. Within discourses of 'community' are also found exclusionary processes that may restrict certain individuals

from access to land and other resources (Li, 1996). These community-based models of REDD+ are therefore, simultaneously inclusive and exclusive, equitable and inequitable, depending on the window of reference and the institutional relationships between related communities (Tubtim \& Hirsch, 2004).

Community-based approaches to REDD+ seek to integrate social and economic development with conservation thus simultaneously enhancing the well-being of people and environments (Pratt, 2009). This community focus has generated abundant critique, especially in political ecology where scholars claim that normative notions of 'community' clash with complex realities on the ground. These realities have prompted 
some scholars to question whether 'community' is indeed the panacea for environmental management it was hoped to be. Critical accounts from political ecologists (see for example, Agrawal \& Gibson, 1999; 2001; Becker, 2001; Black \& Watson, 2006; King, 2007; Mulrennan, 2008) have shown that the turn to 'community' has created unrealistic expectations for the development of 'bottom-up' environmental solutions or served to constitute alterity (Ghosh, 2006). 'Community', for them, is a fundamentally problematic concept riddled with normative assumptions abstracted from the social and political realities of local places (I will expand on the significance of this abstraction for REDD+ later in Chapter eight). The actual conditions of collective life rarely match expectations of bounded, cohesive, and homogenous groups (Pratt, 2012).

Much of the scholarship on communities and conservation start with assumptions of community life then shows how these are disrupted on the ground (see for example Angelsen et al., 2012). Latour (2005: 27) however, contends that there is significant advantage to "beginning in the middle", with the practices of coming together and moving apart, of associating and disassociating that actually make conservation happen. Community-based REDD+ projects then, are essentially land formalisation projects, heavily regulated by the complex constellation of interests within the political forest - a means to provide certain groups and individuals with certain access rights to land (see Hirsch, 2011). Yet, formalisation, cements existing inequalities (Mackenzie, 1993; Benjaminsen, 2002). As Sjaastad and Cousins (2008) point out, this is a concern whenever formalisation is attempted in societies characterised by substantial inequalities in land and other asset holdings, and particularly large groups of rural landless. Fuzzy-bordered customary forests, for the traditional use of certain peoples, transform into an enclosed space exclusively for a select group of individuals. 
Often, this kind of exclusivity is normatively framed as negative and is counter-posed to a positively weighted 'inclusivity' (see for example Agrawal, 2001; Leach \& Scoones, 2015). These framings convey the sense that exclusion is always something imposed on 'local' small-holders by 'global' capitalists - as something to be avoided (Hall et al., 2011). Yet, 'inclusivity', as I have argued here, offers us very little analytical traction, nor opportunities for radical change outside of a globalised economistic geo-political order. To make sense of (and perhaps, radically change) the political forest requires an alternative conceptualisation.

\subsection{CONCEPTUALISING INTIMATE EXCLUSION}

The conceptualisation used here views the inverse of 'exclusion' as 'access'. Although I will trouble this binary in the following section, I do this with the understanding that land use and access in Sungai Lamandau tended to require exclusion of some kind. As Hall et al. (2011) point out, even the poorest people, farming collectively and sustainably, require some assurance that their efforts will not be annexed by outside actors. Starting from the assumption that some degree of exclusion is therefore inevitable (and potentially positive), this framing enables an exploration into the diverse array of ways individuals have both been excluded, and have excluded others, from land and the REDD+ benefits wrapped up in it. Hall et al. (2011: 7) define 'exclusion' as the "ways in which people are prevented from benefiting from things". This is a reversal of Ribot \& Peluso's (2003: 153) definition of access: "the ability to benefit from things", as used in the previous chapter. 
This chapter focuses on 'intimate exclusions', which Hall et al. (2011: 145-146) use to explore “'everyday' processes of accumulation and dispossession among villagers”. This 'intimate exclusion' is integrally linked with processes of cumulative agrarian differentiation. Agrarian differentiation reflects changes in the pattern and magnitudes of ownership of and control over means of production. White (1989: 25) defined it as "a dynamic process involving the emergence or 'sharpening' of differences within [a] rural population". As asserted by Li (2007: 97), these intimate exclusions are often violent, requiring "intervention by force and law" to transform the private property regime while turning neighbours and kin into wage labourers for hire.

However, 'intimacy' here represents more than just the relationship between neighbours and kin, or that which was spatially proximate. Following Pain and Staeheli (2014), intimacy is understood as a set of spatial relations, interactions and practices linking actors across multiple scales and sites of REDD+ implementation. Here, the 'intimate' in intimate exclusion is more contingent upon emotional geographies (of fear, guilt and shame), than a matter of spatial proximity to trees and significant others.

Like Ribot \& Peluso (2003), the concept of 'exclusion' in intimate exclusion considers, but goes beyond, the private property regime as sole mediator of exclusionary processes. The focus here is on the people who are kept out and the powers that keep them out of REDD+ benefit sharing arrangements. The definition of exclusion used here is therefore not explicit, but includes three main types: i) the ways in which alreadyexisting access controls are maintained through the exclusion of other potential users; ii) the ways people who did have access to land were later prevented from doing so through the REDD+ project; and iii) the ways people who previously did not have access were prevented from getting it. This way of looking at exclusion incorporates ideas of 
equity, customary rights and tenure. However, it does not perceive exclusion as something that can ever be fully reconciled within such 'rights-based' private property discourses. Due to the interminable nature of the commodity in question (land), exclusion can never be permanently ameliorated through 'inclusion'; it can only be partially and temporarily relieved through access controls. But this is a contentious position, and not everyone agrees.

For Sikor \& Tranh (2007) exclusion is an ameliorable issue of governance or coming together. They describe a process of exclusive forest devolution in Vietnam, whereby some forest users were given rights to alienate and exclude others. In an unspecific manner, Sikor \& Tranh (2007: 652) recommend the recognition of customary rights and forms of governance that "involve all relevant types of actors". Trudeau (2006; see also Vanderbeck \& Dunkley, 2010) also shares the idea of exclusion's perfectibility. But, he argues that the opposite of exclusion is better understood as 'belonging'. This emotional sense of belonging necessarily entails bounded classifications of characteristics associated with membership in a polity. He argues that membership in such a (territorialised) polity is often a political issue and the politics of belonging (and exclusion) plays a role in the production of social spaces such as landscapes and place.

To some extent the conceptualisation conceived by Hall et al. (2011) builds upon the work of Sibley (1995) in Geographies of Exclusion, who explored how different social groups are geographically marginalised and discriminated against along lines of gender, race, class, sexuality, age, and disability. In particular, Sibley used object-relations theory to examine how difference is used to produce notions of Self and Other, and how these differences create and reproduce social and spatial boundaries. In so doing, he explored how some groups of people are deemed 'out of place' in some locales and are 
pushed to the margins of society. Hall et al. (2011) provide a heuristic basis for mapping these interactions across four 'powers of exclusion': regulation, force, the market and legitimation.

Although this chapter agrees that these powers are fundamental to understanding the processes that resulted in various kinds of intimate exclusions in the study site, unlike Hall et al. (2011), I put the four powers to work within a more anarchist geographical tradition. In adopting a scalar ontology that does not insist on predominant hierarchy, the people, discourses, and misunderstandings which make up the political forest can be better elucidated. There is a danger of overly localising people within abstract geographical boundaries when one uses Hall et al.'s (2011: 145) anthropological designation of "social intimates". Instead, by adopting an intimacy-geopolitics approach, I understand that all actors accessing and adopting exclusionary practices in Sungai Lamandau - the farmers and small-holders, financiers, carbon brokers and buyers, volunteers and researchers - were all networked bodies that disobeyed spatial boundaries and interacted in ways beyond kinship ties or standard geo-political cartographies.

The powers of exclusion, as used here, do not encompass everything one would need to say about how land access was organised in Sungai Lamandau. They are not a master key for social theory, nor are they independent of one another, but rather, they overlap and incorporate lots of other context-specific social processes. Regulation involved setting the terms of use for land and other resources within specified boundaries for specified purposes by specified users. Market-based processes were enacted by influencing the price of land and commodities. Force is discussed here in terms of 
certain kinds of debt/credit relations. Lastly, legitimation is concerned with the normative rationales used by Sungai Lamandau small-holders to exclude other actors.

The four powers are used as a heuristic basis for investigation. These categories are not meant to guide the chapter's critique of exclusion. On the contrary, they explain how exclusions were the normal rather than the exceptional condition in Sungai Lamandau. Hall et al. (2011) refer to this as, exclusion's 'double-edge' - the aspirations for promoting access to benefits implicitly include the wish to administer exclusionary powers.

Exclusions, which occurred within and between the multiple villages of Sungai Lamandau, were never wholly bounded by 'official' village boundaries. Personal relationships were based on and maintained through trade or exchange or marriage and kinship as much as they were informed by historical disputes and animosities. The following section highlights the ways in which processes of exclusion from REDD+ benefits worked among strangers, neighbours and relatives, including those who shared common histories and spaces of common interaction.

\subsection{INTIMATE EXCLUSIONS FROM SUNGAI LAMANDAU'S REDD+ BENEFITS}

\subsection{1 (RE)PRODUCING AGRARIAN CLASSES}

For most Sungai Lamandau farmers that I met, interest in the REDD+ project was dependent upon what one stood to gain. CCI and Yayorin had advised each cooperative to open bank accounts, in order for any future payments from the sale of the project's 
REDD+ Carbon Emission Reduction (CER) certificates to be made. CCI's Forests Programme director explained the implementation model as follows:

The [Sungai Lamandau] project is much more transparent than any other REDD+ pilot so far. I know because [CCI] has paid for most of them and we don't know where the money has gone. [...] When you go to Rimba Raya you (the author) should find out for us if they have made money yet. Please do that. [...] The Sungai Lamandau project, all the money will go to the community. Not Yayorin. Not Winrock - they have already been paid. Not us of course. So the community will manage it and they will get all the benefits.

The Sungai Lamandau project was described by Yusuf, a male member of the Sei Gandis group, as:

A lake, not a pyramid - we will be getting out what we put in. [...] If I want to work I will put my name down and the group agrees on the roster. It will have to be fair or people will break the rules (19 November, 2013).

From most of the farmers I interviewed it was clear that the REDD+ implementation model and management decisions were being negotiated by those with specific interests in the project. Often however, people had more important things to worry about. As Yasan, a male farm labourer in Terantang, told me:

The forest is for timber, that's all. I don't go walking in the forest for fun; I go to cut wood for my house and to hunt rusa ${ }^{21}$. [...] The cooperative isn't working here because we work in the rice fields [...] I have no time for

\footnotetext{
${ }^{21}$ Referring to Cervus unicolor (Sambar deer).
} 
playing in the forest or planting trees which someone else will have (5 August, 2013).

There is little evidence of Yasan's purposeful exclusion from the project. As a labourer, he was seeing little incentive to join an enterprise that he perceived as unproductive. He was possibly blind to the long-term incentives because speculating required a surplus to invest. Yasan was being paid in rice. He had no surplus. Yet, to ignore Yasan's position was to exclude him. And many landed Sungai Lamandau small-holders did just that. Utsman, the leader of the all-male group, Mawar Bersemi (Yasan's local group) explained to me on one occasion:

Our $[$ REDD+] group meets every Sunday. We're very disciplined here. We have to pay our subs every week, we have to attend the [gotong] royong every week to dig our ponds and ditches. If you don't pay one week you can't join the meeting. If you don't attend the [gotong] royong, you pay a fine. Why would we have people join unless they have something to contribute? That wouldn't make any sense (3 November 2013).

These intimate exclusions continued, for the most part, as everyday practices. They were mundane and piecemeal - more a process of obliviousness than malice. Yet, cumulatively these practices were producing (and reproducing) agrarian classes in Sungai Lamandau, with differential access to land and the REDD+ project benefits which came with that. 


\section{4 .2 INTIMATE REGULATION \& EXCLUSION}

Access to REDD+ benefits in Sungai Lamandau was regulated through formalised farmers' cooperatives, which acted to exclude those who were not able to access those with regulatory powers. The REDD+ co-ops set the rules with regards to what members should and should not do with land within the project site. As Irfan, a Yayorin volunteer affiliated with the Sepakat group, reflected:

Each farmers' group decides what they will use their patch of forest for. People who don't live in the village or who don't work in the forest cannot join a [farmers'] group. It's very simple like that. [...] The groups were there before Clinton (CCI) started the REDD+ project, but they weren't formal, they just met from time to time. They drank coffee together. [...] With REDD+ the groups need to be formal or they can't have the land (4 June, 2013).

Through the project, REDD+ co-ops were expected to establish at least one communallymanaged enterprise, which would in principle, provide members with greater economic security, a source of credit, or a means of capital to establish other enterprises in the future. This community mobilisation was intended to influence the construction of Social and Environmental Safeguard (SES) instruments produced by CCI and intended for roll-out across its Indonesia portfolio of projects and beyond. Furthermore, such a seemingly 'inclusive' consultation process would attract 'Climate Adaptation, Community \& Biodiversity Gold Level' certification from carbon credit auditors ${ }^{22}$. Yet, individuals who could not position themselves within a coop, or the project

${ }^{22}$ Verified Carbon Standard (VCS) and CCBA's Climate Community \& Biodiversity Standard. 
implementing consortium, were excluded from both accessing REDD+ project benefits and regulating what those benefits looked like.

The Javanese transmigrant community co-ops of Terantang - Mawar Bersemi and Tani Sejati - consisted predominantly of rice farmers and practitioners of inland captive fish pond aquaculture. For the landed members of these groups, the REDD+ project distributed benefits to households that already had competitive advantage. Most members were affiliated to three or more other development project initiatives and supplemented these incomes with jobs in the urban centres of Pangkalanbuun or Sukamara, as explained by Utsman:

I am the Boss of the group for REDD+ and HKm and I'm also the Boss of the PU (public works) rice irrigation project. [...] We also have 'Blue Earth' (fish stock restoration), PNPM (World Bank community empowerment fund), and a few others. I forget. [...] We've had community groups since I arrived in 1986, when the transmigration village started (12 July, 2013).

Although many Transmigrants relocated as wet-rice specialists, these were engineers, entrepreneurs, major landholders and 'progressive farmers ${ }^{23}$. For them this was another opportunity to increase their capacity to accumulate land and capital for themselves.

For those with the means in Terantang, Sundays were strictly dedicated to gotong royong a voluntary communal work effort. For the Mawar Bersemi group, gotong royong sessions involved building both communal fish ponds and private fishponds on a rotating basis. As Alam, a Mawar Bersemi member, explained:

\footnotetext{
23 See McCarthy et al. (2012) for an explanation of 'progressive farming' in the governance arrangements for landowners in outer island Indonesia.
} 
Missing a gotong royong means you have to pay a Rp35,000 fine ${ }^{24}$. [... To make sure people are serious and disciplined, if you want to join the group you are required to pay a monthly subscription of Rp50,000 and a one-off joining fee of Rp300,000. [...] And it works - all the members attend every week (9 September 2013).

Individuals that did not possess land on which to dig a fish pond had very little incentive to join the coop and submit a weeks' salary for the privilege. In such instances, these individuals could pay to dig others' fish ponds, with little guarantee of reciprocal kindness; they could travel long distances to join a suitable coop in another village (requiring them to be of the correct gender, religion, speak the same language and have a similar livelihood connection); or they were necessarily excluded from any current or future REDD+ project benefits.

Once every three months, the REDD+ coop heads met in Pangkalanbuun for the 'United Rainbow' (PKB) meeting to discuss any business associated with the REDD+ project. The meetings were attended by representatives from Yayorin, BKSDA (Natural Resource Conservation Bureau), Dinas Kehutanan (District forestry office) and OFUK. Each negotiated rules and incentives for the cooperatives acting within the REDD+ site.

Prescriptive requirements had been set by state authorities, including BKSDA and the district forestry office, concerning allowable limits for timber extraction (fifty $\mathrm{m}^{3}$ per annum), and imposing a moratorium on controlled burning and logging over allowable limits. The carbon credit validation agencies had also imposed requirements relating to monitoring and protection of carbon stocks, biodiversity and incidence of 'carbon leakage' (fire, logging and so on). Some groups, such as Sepakat and Sei Gandis, were

${ }^{24}$ About \$3 USD. This represented an average half-day's salary on rural Kalimantan plantations. 
required to have maximum member limits imposed. Land use was however, most heavily regulated between and within the co-ops themselves, through their constitutions. These terms of reference documents varied slightly in content from coopto-coop, but each was largely a reproduction of their umbrella body, PKB's, agreement. This was ratified during a meeting, which Yayorin had facilitated in the project's early stages.

From the twenty-five or so members of PKB, who regularly attended meetings, only two were women - a single representative each from the two women only cooperatives. As well as their absence from formal decision making, women were, generally speaking, excluded from paid forest protection duties. Formal protection of the REDD+ project site and reserve area involved employing forest guards (paid for through an OFI/OFUK grant). Although forest guards usually housed their immediate families within the guard-post huts, no women were formally employed as guards.

Within the Sungai Bulu guard post, women usually performed all the domestic duties required of them as well as performing the duties of the guard - checking SEMAKSI (entry-permission passes), opening the gates to visitors and managing paper-work - all performed without pay (see Figure 6.2).

Figure 6.2: Sungai Bulu Guard Post 


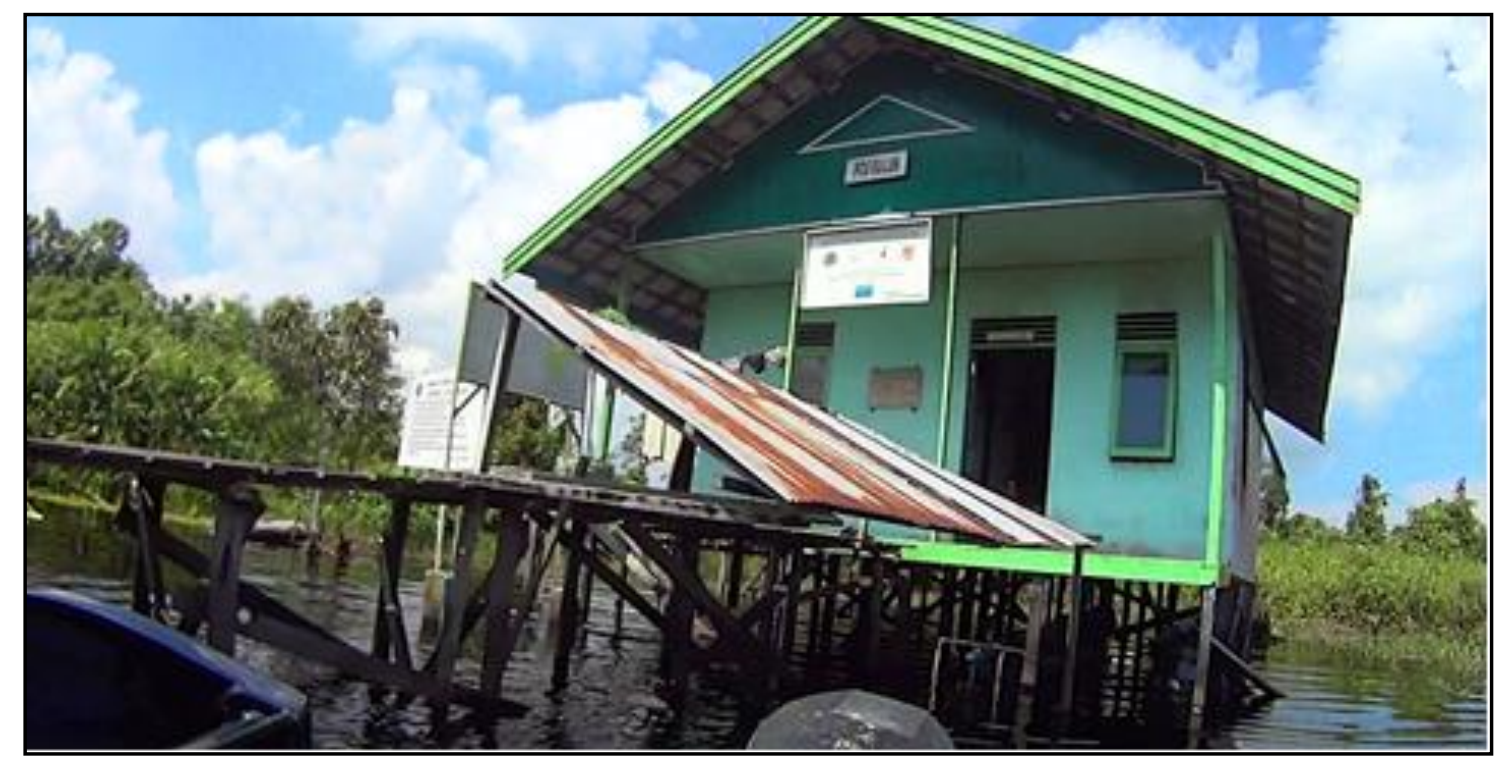

Traditional agricultural or other work that did not bring cash income was generally perceived by the PKB group as female work, while income-earning work was socially considered the domain of men. Adinda, head of the Wanita Mandiri group (and Irfan's ${ }^{25}$ sister), stated in an interview:

I am not a guard - I don't want to do that. [...] You would probably become a guard if you wanted to be a PNS (civil servant), which is a good job and you get a pension and house and school for your children. [...] It is a family endeavour. The woman supports her husband and then he will get a good job as a PNS, which is good for the whole family. [...] Women work in the guard post for free, but it's always that way (2 September 2013).

Many women also worked as labourers to generate cash income for their families, but this was normatively considered as supplemental to their husbands' incomes. Besides

25 Irfan was head of the all-male Sepakat group, in Pendulangan and a Yayorin volunteer. 
being the main farmers of family plots, the holdings often did not formally belong to them, but to their husbands or male children.

Exclusion of certain groups from PKB was usually based on their inability to coalesce around shared livelihood strategies. The fisher folk and their families, located in clusters sporadically positioned along the riverbanks north of Sei Gandis, despite their dependence on the buffer-zone tributaries, were excluded due to their geographical isolation from one another. The fisher folk communities seldom came together. They lacked motorised canoes to reach Pangkalanbuun, and none of their huts were spacious enough to accommodate monthly meetings, let alone house a thriving communal enterprise.

\subsubsection{FORCEFUL EXCLUSION THROUGH DEBT DISCIPLINE}

Force was at the heart of PKB's regulation, yet state actors alone were exercising the right to use force legitimately. But, as focus drew to more intimate regulatory processes, one could see that force was not solely a tool of the state; it was used within the Sungai Lamandau villages to settle personal disputes or debts. It was rarely explicit. The implicit threat of violence proved a more useful tool to exclude or appropriate REDD+ benefits. Possessing these means of violence created conditions in which force acted quite effectively without ever being used.

For example, Pendulangan/Tanjung Puteri's Kepala Desa used the threat of violence to assert his position to secure access to financial REDD+ project benefits. As Irfan, the leader of the Sepakat group described it: 
We formed two village cooperatives: Sepakat and Wanita Mandiri. The Kepala Desa, had no livelihood connection to either coop, so he couldn't join. That's the rules. [...] He started charging a registration fee for new members of around Rp50,000 to Rp100,000, to finance 'monitoring'. People who didn't pay were told they would have their boats impounded if they entered the REDD+ project site without a valid permit (8 July 2013).

Despite lacking the authority to impound boats or levy fines, the threat acted as a means to persuade members to allow him to participate, as well as a means to financially capitalise on the groups' formation. The Kepala Desa was later enlisted as Sepakat's secretary, a position he profited from through dividends of rubber sales. ${ }^{26}$

Elsewhere, the authority of certain individuals appeared more legitimate. For one rubber coop in Sungai Lamandau, the leadership was a reproduction (and cementing) of the traditional paternalist structure that had existed long before the REDD+ project was established. The group's well-connected chief, was the main source of informal credit for all the coop's members and their families and the principal node through which rubber markets in the provincial hubs of Sampit and Palangkaraya were accessed. A male member of the group told me:

Hasan (the group's chief) accepts repayments on loans as rubber. Timber is also just fine, no questions [...] If you have private land you have to promise it as security. [...] My neighbour had a plot of land in Kubu, but he

\footnotetext{
${ }^{26}$ As explained in the previous chapter, the Kepala Desa was later fined by BKSDA, and forced to refund the charges.
} 
lost it when he couldn't pay any more. He still has his house there, but Hasan owns it (6 November 2013).

As argued elsewhere by Gerber (2013), this appropriation of land as collateral was leaving the appearance of a standard 'voluntary' sale on the part of the farmer, but was glossing over the fact that the neighbour was being forced to sell his land in order to finance a debt.

Entering into these credit relations had other hidden consequences: Creditors' acceptance of timber as a repayment method potentially drew the debtor into a destructive livelihood dependent on logging. In concreting the group's hierarchical structure in this way, the REDD+ project had the potential to exacerbate the forceful exclusions which formed a root cause of Sungai Lamandau's forest degradation. Furthermore, Hasan had no real incentive for being reimbursed, preferring to remain as an interest or rent-collector, extracting value from the debtor's work or the fruits thereof. Such mechanisms have been observed elsewhere in Indonesia. Li (2010: 387) found that:

The principal mechanism through which owners of capital have been able to profit from rural peoples' labour and the principal vector of dispossession has been debt. Debt makes nominally independent landholders in effect their tenants, disciplined by the need for further loans and the threat of foreclosure.

Although the cooperative operated 'communal' rubber and cattle enterprises; unlike the other co-ops, Sei Gandis members were forcefully excluded, through debt, from the REDD+ project benefits enjoyed elsewhere, such as: communal savings and loans 
schemes; fixed and guaranteed market prices for rubber or other commodities; and access to land held in common. Improving access to these benefits was not in Hasan's interests.

\subsubsection{EXCLUSION THROUGH MARKET LOGIC}

Just as informal credit was a primary tool in enacting forceful exclusions from REDD+ benefits, the debilitating nature of debt arrangements allowed those with means to control the market and labour conditions to suit their interests. Being able to control market forces was of enormous importance in the dynamics of land access for Sungai Lamandau's small-holders.

Tani Sejati, the REDD+ project's newest coop, located in the rice farming village of Kumpai Batu Bawah (KBB), had formed in early August, 2013. The coop was a mixedethnicity group, but was composed predominantly of Malay Muslims and Javanese migrants. Their first meeting was conducted at the elected chief's house and was attended by all thirty-one members - these men represented almost every family in the village. Facilitated by Yayorin staff, the coop was to agree a constitution document,

REDD+ project management roles, potential enterprises (to increase the economic empowerment of its members), and the coop's finances (including savings and loans schemes, rotating lottery and subscription costs). During the meeting Mahmud, an older Malay gentleman explained, “A communal rice enterprise isn't going to work well for us, because we're old and therefore not strong and in poor health." Many others agreed.

Raist, a Dayak gentleman in his mid-forties, later in the meeting described his willingness to see a rice venture move forward: 
I'm prepared to pay double [the subscriptions] and I think others who are able should do the same. Then we can quickly build sufficient modal (start-up capital for a new business), to buy milling machines and get more to market (3 August 2013).

There were a number of market exclusions at work here. As Hairuman, a member of Setia Kawan explained:

The price of rice, milled, is usually around $\mathrm{Rp} 10,000$ per kilo at the market. [...] Rice farmers and labourers often choose to sell their rice to a middle man for Rp8,000 per kilo, because labourers are often paid in rice and they don't have transport to markets, you understand? If the rice was un-milled, a farmer could sell it at the market for only Rp4,000 per kilo, but middlemen won't buy it because there's no profit. So if you can you would always pay a rice miller, and that's a standard fee of Rp1,000/kilo.

This necessity provided a healthy profit for rice milling machine owners, which included Mahmud, holder of a sizable six-hectare plot. His was one of only two milling machines in KBB. A REDD+ communal rice production venture would allow another to be purchased, significantly cutting production costs and benefiting the landless labourers of the group. For the landed owners of existing profit making machinery, such a project would be disadvantageous.

Unlike the landed members of $\mathrm{KBB}$, the landless lacked the means to speculate on temporally distant pay-offs. They were, instead, compelled to sell their labour to make ends meet. Away from the meeting, Raist explained: 
I'm paid in rice. I have only rice to sell. Sometimes I buy broken motorbikes and sell them in town, but that's for school fees and cigarette money. I can't buy land. I rent the land my house is on and enough for the ducks. [...] The only thing there is plenty of for me, is work. [...] My children have to work hard at school. There is nothing more I can give them here, so they will need to find good jobs in town (3 August 2013).

Raist was not alone. For many of KBB's landless the market-based violence was forcing many to get out of farming altogether (an issue explored with greater detail in chapter seven). Anton, a male Malay farm labourer living in KBB told me:

Today, rice from Thailand is cheaper here than rice from Kalimantan. How is it possible? How can they transport it to Surabaya, then bring it here and sell it cheaper than I can get it from the Pasar Baru market (Pangkalanbuun's main food market)? [...] There is no future here. The Thai farmers get all the help they need to grow rice and get rich. We can't even get basic machines and chemicals. [...] If you have no land and no machines, you're dead here. I'm nearly dead here. Enough (4 August 2013).

It was common for labourers in KBB to acquire informal loans to maintain a 'normal life'. This normal life consisted of being able to eat, produce, pay bills, or meet the basic needs of family life such as weddings, funerals, housing, health care and schooling. Anton was one of these individuals. He had sold his land (he and his family remained as rent-paying tenants) in order to pay for his own medical expenses and purchase a bicycle. 
Unlike Raist, most of KBB's landless labourers saw little incentive to join the REDD+ project. The coop disbanded in early December, 2013, and Raist, Anton and many of the other labourers, continued to work for rice, pay rent, middlemen and rice millers.

From their secure vantage points, the landed small-holders of KBB were able to weighup the advantages of REDD+ against their continued pursuit of purely private interests. However, in doing so, small-holders, like Mahmud, were eliminating the labourers' access to far-distant carbon credit incentives. Titin, Raist's wife, described their situation as a case of "Buta Ayam" (Chicken-sightedness ${ }^{27}$ - 4 August 2013). As Gerber (2013) explained elsewhere, the debtor must adopt and develop a short-term 'algorithmic thinking' in order to avoid bankruptcy and therefore to survive socioeconomically (if not physically). Market prices were confronting the landless as hugely persuasive social facts, which across Sungai Lamandau lead countless times to exclusion. Though they desired it, many of the KBB labourers' participation in the REDD+ project was undesirable to land-holders, who wished to maintain the status quo in their own favour.

Unlike the male labourers of $\mathrm{KBB}$, women had different social roles, rights, and opportunities and were therefore differentially affected by the family's dispossession through land transfers to local creditors. Land in rural Kalimantan, under normal circumstances, was only ever transferred following the death of family members, as Sugi, a female small-holder in Terantang stated in an interview: "If you're poor you must eat old rice. When you are rich, you must try and buy land, and eat old rice" (13 November, 2013). Under normal circumstances, the allocations of inheritance distributed on death usually depended on which child would take care of the parents.

\footnotetext{
${ }^{27}$ - Literally: Very short-sighted or as blind as a chicken as it forages.
} 
The family member (usually a female sibling) who would be caring for the parents would inherit more of the parents' properties (see also White, 2012). When Raist and Titin's land (the final asset to go) was lost, their daughter was still expected to maintain her role as carer, but with few opportunities outside of these domestic responsibilities to build up any financialised security to support her own family.

This predicament has been echoed elsewhere. Recent studies of the gendered dynamics of land tenure in Kalimantan have explored the systematic discrimination that women have experienced in processes of land reforms (Jacobs, 2010; White, 2012). Through these processes, access to REDD+ activities were placed even further out of reach for Sungai Lamanau's women.

\subsubsection{LEGITIMISING EXCLUSION}

The KBB farmers' ability to contest exclusions, or mobilise counter-exclusions, was spatially and temporally contingent. Just thirty-five $\mathrm{Km}$ north, in the village of Tempayung, a Dayak had inalienable access rights to communal land; in KBB he/she did not. In Tempayung, their claims, based on ethnicity, culture and attachment to a place, was legitimised under a banner of indigeneity or unique ability to manage the land effectively (Krause et al., 2013). This process of legitimation can be understood here as the moral justifications for supporting exclusionary practices, thus providing the normative underpinning to certain regulatory, market and forceful powers. For Sungai Lamandau's farmers, legitimation was a matter of appeal to an audience. Although market based exclusions, like those mentioned above, appear unfair, they were certainly legitimate. However, for some, historical ties to Sungai Lamandau were superseding 
claims based on, for example, land purchased in good faith, or through government sponsored resettlement programmes.

Powers of legitimation supported a number of exclusions employed by rubber tappers in Pendulangan, based on ancestral heritage and perceived customary rights to land within the buffer zone. As Neni, a male rubber tapper from the Sepakat group, said in an interview:

From my perspective, the transmigrants have taken more and more of the land in Terantang and Tanjung Puteri. I don't mind. They're welcome to join in projects which help them. We are brothers together. [...] But the transmigrants are from Java. They don't use the forest. They use rice. When they enter the forest it's to cut it down for wood. They don't need to enter REDD+. We use the forest, so REDD+ is for us. They have no rights to it (29 July 2013).

The Transmigrants were often viewed as destructive by the ethnic Malay residents of Tanjung Puteri, due to many from Terantang having sought alternative employment within logging concessions, which later became the REDD+ project site. Fitri, a member of the Wanita Mandiri group told me:

My husband and two of my brothers go into Sungai Bulu every day to tap rubber. Our friends from Yayorin have planted lots of jelutong [rubber trees] with us, which we use for feeding our families. That is REDD+, yes? [...] The people from Java cut down the trees to feed their families. Do you see? They don't fit together ${ }^{28}$ (30 July 2013).

\footnotetext{
${ }^{28}$ Fitri then jokingly wretched upon the accidental consumption of the "terribly sweet" Javanese cakes.
} 
Furthermore, the Malays of Pendulangan and Tanjung Puteri perceived themselves as an unfairly marginalised group sat between the already well empowered Dayak of the interior and the rich landed Transmigrants who occupy the most fertile rice lands. 'Kami suku asli juga!' (We are an original tribe too!), Malay coop members would often say. Yet, through their adoption of Islam, fishing and sea trade, they were not considered as such by indigenous advocacy groups like AMAN, who represented the in-land animist, forest dwelling Dayak interests. As Irfan explained:

My plot is rented. I pay high fees to tap rubber trees on a Dayak family's land. [...] We are friends and they are good people, but they are businessmen. [...] The Dayak have business forums and they are friends with AMAN you know? [...] We're just honest, but we get nothing (15 June 2015).

The Dayak of Kalimantan were celebrating a landmark victory in the Indonesian constitutional courts (discussed earlier in Chapter two), which granted them more secure land tenure. The Malays had no such privileges as an ethnic grouping. However, Sepakat members did have access to the REDD+ site.

As the Head of the Sepakat rubber collective, Irfan was tasked with ensuring the group complied with the REDD+ implementing consortium's access rules, to ensure no more than thirty members could use the Sungai Bulu tributary. All names on the coop's entry permit belonged to Malays. Although many Javanese and Malays in Pendulangan and Tanjung Puteri wished to use the tributary, most were excluded. In an interview, Anjar, a male Javanese water delivery bike driver stated: 
My father had a hut on [Sungai] Bulu that he used all his life. But I can't use it because there are no spaces on the list. But I know most people on the list don't use Sungai Bulu. [...] According to me, only three people there are using their huts. So why can't I use mine? (13 September 2013).

Many members of Sepakat had purchased homes and started families in the urban centre of Pangkalanbuun. For them, their names on Sepakat's SEMAKSI were a matter of security - a social safety net. Irfan had not entered the reserve, other than to escort researchers and tourists, in several months. He had acquired a property brokerage on the outskirts of the town. The ten-hectares of land he owned in Pendulangan remained undeveloped, but for a line of non-native karat rubber trees which staked his claim around the perimeter.

Some residents resorted to other strategies to secure access to REDD+ land. Wanita Mandiri, the Pendulangan women's coop, had incorporated a nipah palm sugar initiative into their activities, which was sponsored through the REDD+ project fund. This arrangement, built-up through tree planting and restoration, enabled the women to gain social recognition of property rights and therefore exclude neighbours from what was ultimately communally owned land ${ }^{29}$, but with potentially positive outcomes.

All the strategies discussed in this section, framed in terms of what was right and appropriate, came together and created changes in Sungai Lamandau's land relations and/or concreted the inequalities already well-established. Removing a neighbour's ability to access land, extinguished his/her most effective incentive to participate in the

\footnotetext{
${ }^{29}$ See Blaikie \& Brookfield, (1987) for an exploration of the exclusionary impacts of, what he calls, "landesque capital".
} 
REDD+ project and allowed the benefits to be accumulated with intensified social differentiation.

This chapter is not suggesting that capital logic dominated the cognitive processes of agrarian communities in Sungai Lamandau. Even when markets and market prices were well established, it was hard to justify the application of pure market calculus within tightly woven communities. Yet, those constricted by debt adjust their thinking accordingly. Punts in the dark on future REDD+ carbon economies and international market forces that were not well understood, became unacceptable risks. But, all these powers of exclusion were differentially effective in each context. Each community's complex historical political ecology, ethnic diversity, degree of intimacy between friends and neighbours, and the capacity for reciprocity and collective action, were key variables in explaining unique patterns of social differentiation, enclosure and dispossession from below.

\subsection{CONCLUSIONS}

The empirical evidence from this chapter shows how exclusions from REDD+ benefits were not something that could easily be controlled. REDD+, as a mechanism to ensure commensurability of carbon products, hides complex intimate dynamics which play powerfully in shaping the distribution of REDD+ benefits. To paraphrase McKenzie (2014) in her UN-REDD blog: predicting the outcomes of a REDD+ project is like throwing a bird and estimating its trajectory, as if it were a rock. Just like the proverbial bird, the Sungai Lamandau REDD+ activity was a complex adaptive system shaped 
endogenously both through its participants' abilities to speculate and their complex social relations and degree of intimacy.

Drawing from Pain \& Staeheli, (2014), the intimacy-geopolitics approach used here, understands 'intimacy' beyond a matter for neighbours, kin and other 'social intimates' living together in close proximity to a specific site of REDD+ production (see Hall et al. 2011). Intimate exclusions have been understood as mediated via a set of spatial relations, interactions and practices operating across multiple scales and sites of REDD+ implementation. The intimate REDD+ exclusions described in this chapter did not fit the conception of well-organised yet anonymously instantiated 'green-grabs' discussed elsewhere (see Fairhead et al., 2012), but rather, were hidden amongst everyday practices and identities.

The conceptualisation of intimate exclusions used here, has not simply taken exclusion as something negative, counter-posed with the positive idea of 'inclusion', but rather as something inevitable, producing sometimes potentially positive outcomes. Viewing the inverse of exclusion as 'access', this chapter has explored the diverse array of ways people in Sungai Lamandau have both been excluded, and have excluded others, from land and the REDD+ benefits wrapped up in it. The heuristic basis mapping the interactions between powers of regulation, force, the market and legitimation are fundamental to understanding the processes that resulted in various kinds of intimate exclusions in the study site.

In the case of Sungai Lamandau, it is clear that the uneven distribution of REDD+ carbon and development benefits intersected with processes of agrarian differentiation that were already proceeding between farmers and small-holders. Through engagement in REDD+ discourses, multiple nodes of state and non-state actors aimed to clarify 
property rights for communities, which facilitated development based on a market economy framework. While this met the goal of simplification in land tenure regimes, it necessarily alienated land and resources from some actors in favour of others. However, this was not a simple process of resource appropriation, but rather the catalyst for incremental micro-processes of enclosure (see Tubtim \& Hirsch, 2004).

The accelerated social differentiation and cementing of existing inequalities were discrete processes. They were there if one looked, but they did not demonstrate themselves on marches, hold placards or mobilise international advocacy efforts. The value of REDD+ products depends on this apparent consensus. The workings of a green economy are wrapped up in all sorts of other good things: community empowerment, economic development, and the desire (felt as a powerful obligation) to intervene in other people's lives - to make them better (Hall, 2013). Yet, despite enacting a certain 'Will to Improve' (see Li, 2007) through the REDD+ project, for some who hoped to secure a share of the benefits, dispossession accelerated towards a more destructive livelihood. Luckily, for those with means, a vague inertia was maintained in which things were left as they were.

Exclusions were not inflicted upon an easily identifiable indigenous subject. 'Indigeneity' is a hugely complex category in Indonesia, often rendered neat and malleable by REDD+ research that fails to understand its nuances. Internationally recognised standards of indigeneity, enabling comparisons acoss continents and cultures, offers insufficient analytical traction to elucidate the complex forests of Kalimantan and beyond.

This chapter has demonstrated that changes in common-property arrangements were occurring between actors across sites and scales of implementation. What is more, these 
rearrangements in land and the market economy did not occur in an isolated context, but through a reaction to wider processes of exclusion, exacerbating competitions for land control and the associated REDD+ benefits. Many individuals supported aspects of this market economy development and welcomed a more exclusive property regime to facilitate such development. The augmenting of traditional values surrounding land use, debt and market relations in Sungai Lamandau was not therefore, simply an imposition orchestrated by project implementers, but rather a process in which local farmers colluded.

Yet, as I will explain in the following chapter, the losers did not always disappear or move along quietly, but sometimes countered their exclusion with violence. 


\section{CHAPTER VIOLENT EXCLUSION \& SEVEN COUNTER-EXCLUSION}

\subsection{INTRODUCTION}

Aside from a few exceptional cases (see for example Cavanagh \& Benjaminsen, 2014; Nel, 2014), resistance to forest enclosures for carbon rarely constitute a loud and frenzied revolution, but are more often made up of semi-coherent whispers, misunderstandings and elusory chains of causation (McCarthy et al., 2012). REDD+ projects rarely compare to the heated clashes common within Indonesia's mining, logging or plantation sectors (Gamu et al., 2015). Take for example, the PT. Arkon coal mine in Kalimantan. A report produced by Friends of the Earth Indonesia (WAHLI DTE, 2010: 1) explained:

On 20 August, 2010, local people demonstrated to demand the return of their customary land. The protesters were beaten, kicked, and shot at. One person was killed, four other people were injured and two have been maimed for life. Another twenty-four people were jailed with seven month sentences. In contrast, no trial has been held for the security officers involved in the shooting and killing. 
The report then went on to discuss the impact mining activities were having on local prostitution, health, flooding, etc. Although REDD+ projects tend to avoid the direct corporeal violence that appears commonplace in the mining sector, this chapter argues that when picturing a violent landscape, one should not only centre on these momentary acts of violence, but rather on the full context of the disruptive moment the often hidden or 'everyday' processes of violence.

As argued in the previous chapter, enclosure of resources and the exclusion of individuals, or groups with alternative claims to those resources, have long been recognised as sources of violence (Peluso, 2007). In this respect, accumulation of land for profit is achieved through violent, coercive actions. As Harvey (2005) explains in The New Imperialism, accumulation occurs at other people's expense. Federici (2004: 64), in Caliban and the Witch, shows in graphic detail how violence was used in acts of accumulation, including the enclosure of women's bodies. She notes that in most cases, violence is "the main lever, the main economic power, in the process of primitive accumulation". Violence is also a major theme in Arendt's (1966) descriptions of accumulation via imperialism in The Origins of Totalitarianism (see also Kelly, 2011).

Although this violence is always associated with actual, or a threat of, physical force, the violent exclusions and counter exclusions addressed in this chapter were of an implicit kind - hidden away in market-based, regulatory processes. Despite lacking Federici's gore, the violence explored here is in some respects more insidious - taking on a legitimate character whilst concretising structures of discrimination. Yet, violence was also a cathartic and liberating tool for Sungai Lamandau's excluded farmers, seemingly rooted in a feminist ethic of care (Bell, 1993). 
This 'ethical violence' is necessitated by the fact that inequality and violence are mutually constitutive; as Galtung (1969) identified when he coined the term 'structural violence'. Inequality begets violence, and violence produces further inequalities. Therefore, as Springer (2012: 9) argues, "if we want to disempower the abhorrent and alienating effects of either and rescind the domination they both encourage, we need to drop the calculative approaches and consider violence and inequality together as an enclosed and resonating system," that is, as a spatially and temporally diffuse moment.

Distribution of benefits has been identified in previous chapters as the most challenging hurdle facing Indonesia's REDD+ projects (see also Costenbader 2010; Luttrell et al., 2013). A significant pragmatic element to the debate lies in the idea that if REDD+ is not equitable it will be perceived as unjust (Börner \& Wunder, 2008). This perception can undermine project effectiveness, legitimacy, and sustainability (Peskett 2011; Lindhjem et al., 2010; Costenbader, 2010), leading to increased conflict, localised violence and a higher risk of 'non-permanence' (Mohammed, 2011; Cotula \& Vermeulen, 2009). White et al. (2012) argue there is a need for more comprehensive and systematic empirical research on violence within projects involving land enclosures. But, violence is not a thing which should be expunged at all costs, as Douzinas (2013: 86) explains, violent resistance will never quite go away in the existent system of order. As long as injustice, inequality and dislocation exists it will be 'right' to be violent: "right, not only in its strict legal meaning - as a claim accepted or seeking admission to the law, but also as a will that wills what does not exist or what is prohibited."

Without an understanding of how exclusion and counter-exclusion are constituted within benefit access arrangements, the Sungai Lamandau REDD+ project may fail to address (or even exacerbate) social inequalities and environmental violence - root 
causes of Sungai Lamandau's forest degradation. As the community-based model instituted in Sungai Lamandau is intended for roll-out across the region, it is imperative that the potential environmental violence in instituting it are recognised as well as the spatially constituted implicit social violence that precedes it.

The following section considers the legitimation of these violences. It discusses the violent imaginaries of land and people required to assemble a REDD + forest for investment. The chapter then introduces the conceptual framework used for exploring the intimate 'narratives of violence' within the project's complex entanglements of power. Using the four 'powers of exclusion' analytic discussed in the previous chapter, the penultimate section discusses the violent exclusions and counter exclusions from REDD+ benefits as they were mobilised in the Sungai Lamandau study site. These discussions inform the chapter's conclusions.

\subsection{ASSEMBLING THE REDD+ FOREST FOR CAPITAL \\ INVESTMENT}

\subsubsection{THE OBSCENE SUPPLEMENT OF THE GREEN ECONOMY}

Taussig (1998; see also Swyngedouw, 2011) suggested that while the ecological crisis threatens the future of life on Earth, it is becoming increasingly difficult to imagine addressing this crisis in anything other than capitalist terms. "It is easier [...] to imagine the end of the world than the end of capitalism" (Taussig, 1998: 251). It is this illusion of inevitability that maintains the dominance of market-based solutions for climate change

within the green economy. Žižek (2008) suggests an obvious split between the overt 
constructions of the green economy in this illusion, and its obscene underside - violent processes of dispossession. Žižek claims the overt rule of law is always sustained by such an obscene supplementary element that transgresses the conscious element. In this respect, one could perceive the green economy idea as only a 'tongue-in-cheek' solution to an urgent ecological crisis (Delay, 2014), satisfying the market assemblage's need for capital expansion without meaningfully engaging in the problem it professes to fix.

In the context of the green economy, one is generally forbidden, within the existent 'symbolic order' (Lacan, 1977), from seeking to directly resolve the ecological crises or to take it too seriously. For example, one may attend a 'People's Climate March'30, sponsored by 'clean development partners' such as Lockheed Martin and BMW. One must not 'Flood Wall Street' ${ }^{31}$ or occupy public space with the intention of preventing the normal running of consumer capitalism. In the context of REDD+ as a means for promoting tropical forest protection, the acceptable resolution within the existent symbolic order is of course market-based, requiring the (re)enclosure of forests as private property and disciplinary techniques to enrol efficient market-subjects.

To operationalise REDD+ projects within the existent symbolic order, requires the construction of spectacles (Cavanagh \& Benjaminsen, 2014), creating an imaginary that tropical forests are 'under-utilised' (Deninger et al., 2011); lack suitable 'green infrastructure' (McCarthy et al., 2012); or support destructive 'forest dependent communities' (Nel \& Sharife, 2012). Spectacle, drama, performance, or what Tsing

\footnotetext{
${ }^{30}$ See http://www.climateweeknyc.org/partners-sponsors/ for a full list of the 2014 Climate March corporate partners.

${ }^{31}$ In New York County Court (03/03/2015), eleven \#FloodWallStreet arrestees refused a plea deal and pled 'not guilty' for a sit-in at Broadway and Wall Street on 22/09/2014. They demanded a trial arguing that "direct action employed to fight climate change at the source is both morally and legally justified". (http://floodwallstreet.net/\#new-york-city).
} 
(2005) refers to as the 'economy of appearances' is an essential component of the economy of carbon finance. As Tsing (2005) shows, conjuring the plausibility of resources within Indonesia's forests requires the promoters to emphasise the deep, dark, loneliness of the jungle, and to overlook the presence of thousands of artisanal workers who had been labouring for decades in the area and knew quite well what was and was not there (Li, 2012). Promoters also call upon traditions of 'frontier' investment - the cultural myth of the lucky find, and the idea that being bold and early can bring huge rewards (Li, 2014a). As Bridge (2001) argues, frontiers are imagined (and constructed) as sites of 'bountiful emptiness'. They are 'fecund' spaces, 'empty but full'. That is, they are empty of people, histories and claims, but full of potential for new and improved use.

The most spectacular mode of enrolling REDD+ forests in the green economy involves what the World Bank ${ }^{32}$ refer to as the forest's 'yield gap' (Deninger et al., 2011) - the huge untapped potential of idle people and empty forests, awaiting only technology and capital to make them productive. The World Bank's report tactlessly divides the world's 4.5 billion hectares of 'potentially productive land' into two parts: a cultivated part and an uncultivated part covered by forests for carbon. Entire nations are plotted on axis according to the criterion of 'dollar-value efficiency'. These spaces form the global stock of up-for-grabs 'underutilised land'. This process, which Demeritt (2001) calls 'statistical picturing', is one in which scientists and other 'experts' play a prominent role working to provide a target for permissible climate action, while reinforcing the symbolic order of market-society.

\footnotetext{
32 World Bank Rising global interest in farmland report (2011).
} 


\subsubsection{KILLING THE COMMONS: INGRAINING THE 'RIGHTNESS OF PROPERTY'}

REDD+, as part of a green economy, depends on large-scale land acquisitions in order to create cost-effective solutions for climate change mitigation (Fairhead et al., 2012; Pearce, 2012). Aquiring land on these unprecedented scales requires enclosures and exclusions legitimised through a series of virtuous green spectacles (Cavanagh \& Benjaminsen, 2014): The green economy is said to increase global production to meet demand; it 'grows' national economies; it supplies food for the world's poor and hungry masses; and it offers this without degrading tropical forests (O'Lear, 2015). Low population density in the target areas of rural Indonesia means it could do all this while respecting the rights of local people by incorporating their land through lease or purchase, or by creating protected enclaves in which they can continue their lives much as before, if that is their preference (Li, 2014).

Unfortunately instead of mitigating land conflict, market-based environmental management in Indonesia has significantly increased the vulnerability of small-holders to landlessness (see McCarthy et al., 2012). With the refashioning of traditional landholding patterns through a market-based model, the motivation to acquire land in rural Kalimantan is no longer concerned with sustenance, but is instead primarily related to profit, where speculators seek to 'get ahead' (i.e., to gain ascendency or to exploit) via the accumulation of land transformed into property (Li, 2012). The result is a tendency towards significant labour fragmentation and displacement that intensifies 'deagrarianisation' (Rigg, 2012) as rural peoples are stripped of their foot-hold on the land that has traditionally sustained them (discussed further in Chapter seven). 
To legitimise these continued violent exclusions, wrapped up in the green economy's appropriation of land for carbon, requires a 'rightness of property' (Malhi, 2011; Springer, 2015). Whether to service community-based environmental management (see Tubtim \& Hirsch, 2005), or other effort of private speculation, the distinction between access to land as temporary 'possession' and access to (or ability to accumulate land as) 'property' for profit must be blurred. A popular amnesia needs engrained where memories of theft are erased and replaced with ideas of 'rights' to things. In doing so REDD+ does not create a regime of accumulation by dispossession (Harvey, 2005), but rather perpetuates the on-going instruments of market-based violence that enable the regime's continuity. Within such a symbolic order, no alternative appears obvious, and the individual becomes defined not by being, but by having (Hardt \& Negri, 2009). In other words, to have political significance before the law and to be included in the symbolic order, that is, 'to count', one must hold property (Springer, 2015). Proudhon (1840 [2011]) contrasted this supposedly God-given, sovereign right of 'property' viewed as an affront to the liberty, equality, and security of the community - with 'possession', which cannot be mobilized for exploitation as it is based on actual use. Land that people use to reproduce themselves is then regarded as a possession, while land that is rented to others becomes a means for exploitation and is thus considered property.

While property attempts to mobilize the means of production as a natural, sovereign right of an individual (i.e., a proprietor), Proudhon (1840 [2011]) argued that this was an illegitimate form of use that constituted a form of theft from the commons. In his view, such means should not belong to a proprietor as a so-called 'natural right'. Instead, everyone connected to the said means of production should share in the bounty 
and surpluses it affords. I am not though suggesting that everything should be shared. When analyses of accumulation and dispossession assume that opposition to capitalism requires opposition to any form of markets or private possession, and that people only engage with markets or want property when forced to, they suggest a politics at odds with what seem to be the wishes and interests of many people (Hall, 2012). However, one's possessions should be their own based upon their continuing actual use. Property is thus defined by its mechanism of exploitation, which makes it fundamentally different from possession insofar as it relies on coercion, exclusion, hierarchy, and most notably, force (or law) to maintain its viability (Springer, 2015).

Baird (2014) argues that political memories - memories of formalised exclusions - are particularly relevant when it comes to legitimising the 'rightness of property' and servicing the green economy's land requirements. He also stresses, in relation to various large-scale plantations, mining and hydropower dam concessions, the importance of political memories in (re)shaping understandings of particular varieties of memoryladen political landscapes. However, these 'shared memories' within these landscapes are rarely uniformly accepted by all. For example, years of dictatorial rule in Indonesia can be remembered for their hardships or occasionally with fondness for their stability and 'pemimpinan ketat' (assertive leadership). These memories are constituted by the past but are also politically mobilised in the present. Memory and politics shift enclosures from a violent to a legitimate truth. Furthermore, shared understandings of past events shape perceptions concerning what is right, possible or pragmatic today, especially when the rightness of property remains contested.

All property claims represent appeals to an audience based on reciprocal moral foundations (Blomley, 2003). People accept the private property appeals of others, 
because they also want private property. For those who do not share this moral foundation, based on prescribed limitations on their ability to own or make use of property, this symbolic order is more easily broken.

\subsubsection{CONSTRUCTING ILLICIT OTHERS}

There needs to be a clear differentiation here between acts that constitute an authentic and violent break, which challenge the morality of a market-based symbolic order, and those that work to perpetuate that order. To exemplify the latter, take the London riots in the summer of 2011. Although triggered by the suspicious shooting of Mark Duggan by police, many of the rioters arrested agreed that their actions were rooted in a general malaise of social deprivation concerning access to affordable credit (Till, 2012; Bauman, 2011). Badiou (2012) has argued that this malaise is one of the main dangers of the market-society: although by virtue of being 'global' - it appears to encompass the whole world - it sustains a 'worldless' ideological constellation in which people are deprived of their ways of locating meaning. This is why it is difficult to conceive of the rioters as authentic revolutionary subjects. Žižek (2011) suggests that they fit much better the Hegelian notion of the 'rabble', those outside organised social space, who can express their discontent only through 'irrational' outbursts of subjective violence - what Hegel called 'abstract negativity'. This subjective violence works to reinforce the primacy of the market both by engraining limitations within subjects of any potential alternative to the market-society, but also by acting as a kind of 'pseudo-violence', legitimising the market-based symbolic order. As Žižek (2008: 183) explains: 
The threat today is not passivity, but pseudo-activity, the urge to 'be active', to 'participate'; to mask the Nothingness of what goes on. [...] The truly difficult thing is to step back, to withdraw from it all. Those in power often prefer even 'critical' participation or a critical dialogue to silence, since to engage us in such a 'dialogue' ensures that our ominous passivity is broken.

An authentic revolutionary act that transcends the market-based symbolic order, as proposed by Žižek (2008: 183), is

violent precisely insofar as it entails ceasing this obsessive activity. In it, violence and non-violence overlap (non-violence appears as the highest violence), likewise activity and inactivity (the most radical thing is to do nothing).

REDD+ in Indonesia has been framed as a solution to violence inflicted on the environment (see Innes, 2014). Within this frame those suffering from the malaise of dispossession are forced into 'de-agrarian livelihoods' (Rigg, 2007; Hall et al., 2011) or are Othered (Said, 1978) as 'illegal loggers', poachers, greedy miners or arsonists. In reality though, REDD+ facilitates the violence's continuity, enabling the legitimising imaginary, of small-holders as the cause of forest degradation in Indonesia, not large international corporations.

Building on Said (1978), a few critical geographers have revived themes of empire and orientalist concerns in their analysis of violence and the geographies of property (Blomley, 2003); the geopolitics of warfare (Gregory, 2004; Dalby, 2010); and economic development (Springer, 2010). Few, if any, have considered the links between orientalising imaginaries and their relative impact on human-ecological systems. 
Frayling (2014) draws upon a wide range of cultural references - fiction, film, theatre, television and playground behaviour - to plot the rise of a Western paranoia towards environmentally destructive state-sponsored Asian industrialisation. Monbiot (2015: 1) refers to this as "recycling the old 'Yellow Peril' myth" - the idea that the 'Asian' does not care for conservation of forests, only growth, and to maintain competitive economies, we (the working women and men of the West) must think and do likewise. Yet, paternalistic assumptions that only people living in rich nations can afford to care about forests are of course violent myths. They are violent not only in that they justify inaction for reducing consumption patterns in 'Western' countries, but also because such violent imaginaries inspire the wrong kinds of intervention to prevent the destruction of forests.

Many people in South-East Asia care more about deforestation and climate change than those in, for example, the UK or New Zealand. A 'Greendex' (2015) survey of consumer attitudes conducted by National Geographic suggested that twenty-six per cent of respondents in the UK and thirty-two per cent in New Zealand believed that climate change is "not a serious problem" ${ }^{33}$. In Indonesia the figure was only four per cent. In the US, seventeen per cent do not want their government to endorse any international agreement addressing climate change. In Indonesia only one per cent wants no action taken (ibid).

As the Greendex survey suggests, many people in poorer countries tend to feel much guiltier about their impacts on the natural world than people in 'rich countries', even though those impacts might be far smaller. The people surveyed in Germany, the US, Australia and UK felt the least consumer guilt; while the people of India, China,

\footnotetext{
${ }^{33} \mathrm{http}: / /$ environment.nationalgeographic.com/environment/greendex/
} 
Indonesia and Brazil felt the most. As Monbiot (2015) suggests, the more one consumes, the less one feels, the more environmentally violent one tends to act.

\subsection{CONCEPTUALISING VIOLENCE}

Sticking within the four 'powers of exclusion' (Hall et al., 2011) analytic (discussed in Chapter six), it is important to note that force - physical violence, whether realised or implied - is important to the legitimation, regulation, and market-based operation of all property concerns and their legal basis of existence (Hall et al., 2011). As Sarat \& Kearns (1992: 1) explain: "[L]aw is a creature of both literal violence, and of imaginings and threats of force, disorder, and pain. [I]n the absence of such imaginings and threats there is no law." Yet, as a concept, 'violence' remains extremely slippery. Instead of policing a strict definition here, this chapter deems the instability as crucial for understanding the reactions it encourages. Furthermore, limiting a definition of violence neglects injustices rooted in the enabling structures of violence.

Benjamin (1921) in Critique of Violence, explored a general tendency to obscure violence in its institutionalised forms and inclinations to exclusively regard violence as something we can perceive only through its direct bodily effects. Benjamin used the idea of 'divine violence' in order to designate 'an Act' - a brutal disruption, which exists external to any law that could maintain it. It should be contrasted with 'mythic violence' which is a means of establishing the rules of law, or the legal social order. Arendt (1963) exemplified mythic violence in a recount of how the Nazi officer, Adolf Eichmann defended himself during his trials in Israel, by appealing to Kantian duty for his part in the 'Final Solution'. Arendt (1963) called this the embodiment of the banality of evil. For 
her, one does not need to be fanatical, sadistic, or mentally ill to murder millions; that it is enough to be a loyal follower eager to do one's duty from a desk (Levy, 2006).

In Benjamin's terms (1921: 297):

If mythic violence is law-making, divine violence is law-destroying; if the former sets boundaries, the latter boundlessly destroys them; if mythic violence brings at once guilt and retribution, divine power only expiates; if the former threatens, the latter strikes; if the former is bloody, the latter is lethal without spilling blood.

Rooted in Lacan's (1977) triptych of psychoanalytic theory, Žižek (2008) distinguishes this blood-spilling 'subjective violence' from its 'objective' counterpoint. Subjective violence is according to Žižek, the perceptibly obvious violence seen on the news or on the streets in the form of crime and terror, civil unrest or international conflict. This is the most 'visible' portion of the resistance spectrum. 'Objective violence' is the 'unengageable' processes of violence that take the shape of either the symbolic (bound in language and its forms - see Bourdieu, 2001; Jiwani, 2006) or the structural (e.g. the catastrophic consequences of the global market economy when it is functioning normally - see Galtung, 1969; Farmer, 2004). Structural and symbolic violence, "may be invisible, but [they have] to be taken into account if one is to make sense of what might otherwise seem to be 'irrational' explosions of subjective violence" (Žižek, 2008: 2).

Following Marx's argument that the world is composed not of 'things' but of 'processes', Harvey (1996: 49) argues that every historical form is constituted by its fluid movement, where things do not "exist outside of or prior to the processes, flows, and relations that create, sustain, or undermine them". When we consider violence using 
this concept of 'moment', one can observe its spatio-temporality. These violent moments are not still pictures, but moving ones, as Hartsock (2006: 175-6) explains:

The concept of 'moment', then, can be analytically very useful in both separating out the social relations the theorist wants to concentrate on while at the same time reminding us that these social relations are in fact connected with and defined by other social relations with their own pasts and future possibilities.

When one acknowledges violence, what one sees is not a 'thing', but a moment with a past, present and future that is determined by its elaborate relations with other moments of social process (Springer, 2012). The material 'act' of violence itself is merely a 'Real' (see Lacan, 1977) nodal point, a snapshot of oppressive social relations. On its own the 'act' does not mean very much. The missing imaginary and symbolic elements are what make the Real 'act' profoundly un-just, humiliating, painful or emancipatory.

Violence (specifically memories of violence) is one of the most profound ongoing stories influencing the (re)production of space (Springer, 2011). Individual and embodied narratives of violence form constellations that delineate and associate place. These violent narratives should not be considered as simply stories about violence, but rather as spatial metaphors (Massey, 2005). However, when these narratives include only the direct, corporeal offences to a person(s), one runs the risk of relegating violence to irrationality.

Springer (2011: 91) argues that all violence is rational: "The notion that violence is ever 'irrational' is a colonial ascription applied to individuals and cultures in an attempt to mark them as 'Other'”. As mentioned earlier, these processes of symbolic 'Othering' are 
an essential part of REDD+ legitimation and regulation. With this in mind, how should a broadened conceptualisation of violence be put to use to inspire emancipatory change?

Using a feminist critique, Bell (1993) offers some ideas. She places a Sartrean existentialist conception of liberation at the heart of ethics and argues that only an 'ethics of freedom' sufficiently allows for feminist critique and opposition to a status quo imbued with violence. Featuring a colonial formation in any analysis of violence helps make that violence legitimate. As Bell (1993: 149) states: "In their different ways, these ethical theories support the status quo and undermine the reformist and revolutionary activates of feminists and others concerned with oppression".

Like Bell (1993), I argue that the pursuit of social and environmental justice is at the heart of the feminist endeavour, and that endeavour is by necessity a violent one. As Vaneigem (1967 [1994]: 163) puts it, "so long as we have not managed to abolish any of the causes of human despair we have no right to try and abolish the means whereby men [sic] attempt to get rid of despair". The 'sic' is not inserted to bring-in women alone. This counter violence, must consider all human and non-human actors swept up and rebounding in violent pursuits. A feminist-inspired intimacy-geopolitics lens is therefore essential to an emancipatory analysis of all kinds of violences.

Violence is a key theme for intimacy-geopolitics (Pain \& Staeheli, 2014). This chapter understands violences as operating through intimate emotional and psychological registers as a means of exerting control. Violence, through the intimacy-geopolitics frame, is therefore linked to wider social norms, obligations and customs, and to economic relations (Hays-Mitchell, 2005). Violences are often understood as explicitly or implicitly sanctioned by states and institutions. In this way, violence plays a 
fundamental role within systems of oppression and the insecurities that disproportionately affect those excluded (Koopman, 2011).

Because of the 'silent violence' (Watts, 1983) implicit within market-based social reforms, through their utter prevalence and banality, one is all too frequently blinded from seeing the violent exclusions of everyday life (Scheper-Hughes, 1993). Instead, violence is seen only through geopolitical webs of hegemonic masculinist control. In much geographical analysis violences have been separated out, positioned either as local or everyday, or as objects of international or political conflict (Dalby, 2008). These separations result in multiple undesirable effects. This chapter instead unpicks and draws connections across different forms of violence and insecurity (Pain \& Staeheli, 2014). These connections wrap together places and people in close proximity with that which was distant. Counter-violence is also understood as moving and working across intimacy-geopolitics. This counter-violence does not simply sit as oppositional to violence, but is in dynamic relation with it.

Žižek (2008) suggests the success of countering the structural violence of everyday life should not be measured by the sublime awe of its ecstatic moments, but by the changes left at the level of the everyday - the day after the insurrection. This countering need not only violate the predominant rules, but may create its' own new rules and impose new ethical standards. "What we hitherto took as self-evident is now seen as deeply problematic; what we hitherto perceived as something criminal, now appears as a heroic ethical act” (Žižek, 2014: 1). Like Žižek, the conceptualisation of violence used here advocates a politically transformative stance, given the structural causes of many of the issues it confronts. Yet, it acknowledges that Žižek was wrong to posit such a stance as a radical break constituted ex nihilo (Robinson \& Tormey, 2005; Douzinas, 
2013). As Scott (1990) shows in a series of case studies, political revolutions tend to emerge through the radicalisation of existing demands and resistances - not as pure violent 'Acts' occurring out of nothing (Žižek, 2008). Even when they do not constitute interruptions of 'normal' daily life, they are a product of the development of subterranean resistances and counter hegemonies among subaltern groups.

Drawing on Sharp et al. (2000) the conceptualisation used here stresses that wound up in 'entanglements of power' are countless processes of domination and resistance which are implicated in, and mutually constitutive of, one another. This positioning maintains Foucault's domination-resistance couplet in which, "power must be analysed as something which circulates. [...] Not only do individuals circulate between its threads; they are always in a position of simultaneously undergoing and exercising this power" (Foucault, 1980:98). Rather than conceptualizing power as aggregated from a central point, using this framework, modalities of power are diversely constituted in space via a multitude of 'everyday' practices (see Allen, 2004). This conceptualisation therefore attempts to connect the Žižekian Act to a positive project of world-changing, relying on alternative imaginaries, and the ability to dream (Vaneigem, 1967).

A transformative politics is therefore theorised here as an 'everyday' process of transformation which forcefully breaks the existent symbolic order. Such a politics could include an a-linear, rhizomatic, multiform plurality of violent resistances, initiatives and violent Acts, which are sometimes spectacular and carnivalesque, sometimes prefigurative, sometimes subterranean, and sometimes rooted in direct and subjectively violent institutional change and reform (Robinson \& Tormey, 2005). Although Žižek articulates the necessity for a broadened perspective of structural and 
symbolic violence, a genuinely transformative politics should stress the necessity for the prefiguration of alternatives.

Thinking again through the four powers of exclusion, the next section explores the moments of violent exclusion - the symbolic, structural and subjective (involving both human and non-human actors) - as well as the myriad counter exclusions playing out in the Sungai Lamandau study site. Space is critical here. The bountiful spaces of the commons - owned by no-one and everyone - I want to show, were also violent spaces forcing people into illicit livelihoods.

\subsection{VIOLENT EXCLUSIONS \& COUNTER EXCLUSIONS IN SUNGAI LAMANDAU}

\subsubsection{ENVIRONMENTS OF SYMBOLIC VIOLENCE}

The REDD+ project did not overtly dispossess people or enclose land formally held in common in Sungai Lamandau, but it did rely on the same instruments of market-based force, creating market subjects through the 'rightness of property'. The violences, upon which this section focuses, were of an implicit kind, hidden away in discourse and structures of discrimination. Symbolic violence was an effect of the production of imaginaries. One of the many REDD+ project objectives was to enable the proposed 'beneficiaries' to become more entrepreneurial - economically independent risk takers (Joshi et al., 2010). Yet, these REDD+ entrepreneurs would need to be dependent on Sungai Lamandau's forests' continued conservation. Therefore, the project initiators' 
vision relied on a self-perpetuating imaginary of farmers as attached to forested land held in common.

Yet, it was apparent that in many villages the commons had become stained with shame. Perhaps things had always been that way in Sungai Lamandau, or perhaps this was a trend reflecting cultures of late liberal consumerism (see also Hirsch, 2012). But, even the picking of vegetables from the river bank had become associated with penury and need for private land. Hiasinta, a female resident of Kumpai Batu Bawa, tried to rationalise the associated symbolism of the commons:

Don't you think it's crazy that we buy mustard greens and cassava leaves from the market in Pangkalanbuun? They grow right here on the door step. [...] I buy vegetables from a seller who comes to my house on his bicycle. He probably picked them from my land (11 August 2013).

For many landless labourers weathering crises, the compulsion to renounce the commons' resources of unenclosed spaces, due to its symbolism, was pushing them into protected forests to sustain themselves - areas under less surveillance from neighbours. However, as Kelly (2011) suggests, many people officially excluded from their former sites of economic reproduction, use resources within protected areas in a less sustainable manner. They may "take as much as they can, making the most of [their] time spent at risk of imprisonment, injury, death or fines at the hands of park guards" (Kelly 2011:696). These groups may not feel a sense of ownership over the forest and its resources, or feel unable to defend it as they could their own property.

Despite official sanctions and regulations, some group members continued to access protected areas for agriculture, grazing, timber harvesting, and hunting. As explained by 
Adi, a member of the Sei Gandis group: "What can I do? I have nothing. They can fine me if they like, but I can't pay" (21 September 2013).

Although the REDD+ project site was intended as a space for forest dependent peoples' economic reproduction in a sustainable manner, perversely those without formal title to land were often the ones excluded from accessing Sungai Lamandau's forests. As explained by Rizky, a male Kumpai Batu Atas resident:

I don't have land so I can't join [the Tani Sejati group]. So, I can't get on the groups' SEMAKSI (BKSDA entry permit). And, I can't enter [the reserve] through the gates, even though I have always used the forest. My grandfather and I used to hunt together with sumpitan (blow-pipes). [...] We use a friends' boat from time to time. [...] We use it to look for gold on the sand flats. It's very difficult now. [...] We come back at night so that we are invisible like ghosts (28 August 2013).

The entry limitations inevitably lead to violence inflicted on Sungai Lamandau's forests perpetrated by those excluded - those who relied on the forest to make ends meet. Yet, under secure conditions, entry and exit to the forest was taking place by covert means, without monitoring of resources collected. Illicit logging, poaching, and mining with heavy metals, risked silently undermining the REDD+ programme (see Gunawan, 2015).

Depite the prevalence of illicit practices, in theory spaces were available for landless farmers to economically reproduce themselves with, should they require them. However, powerful processes of symbolic violence prevented such access. As argued elsewhere, within land access regimes more powerful actors enjoy unchallenged privileges in accessing resources and power through which they dominate the means of 
social interaction (Nightingale \& Ojha, 2013). People with access to land in Sungai Lamandau therefore, and those excluded both accepted the existing order and practices as being 'natural'. The violent result was a necessity for those excluded to economically reproduce themselves by more illicit means.

\subsubsection{VIOLENT MARKETS}

It is within market-based processes where "exclusion's double-edge" (Hall et al., 2011: 188) was felt most acutely - people wanted the right to exclude, but did not want to be excluded. One violent example could be seen in the rice production centres of Terantang and Kumpai Batu Bawa, where on the arrival of Transmigrants in the 1980s, free access to common land gave way to a system of land holding as private property. An equal apportioning of land had slowly given way to a formation of 'Haves' and 'Have-nots'. Transmigrants, such as Bambang, described the hardships experienced as a community, and how a culture of reciprocity had grown through mutual adversity:

When I arrived with my wife and children in 1987, we didn't have the drainage canals. We could hang our rods and catch fish from the windows. I'm serious, I'm not lying. We laugh about it today, but they were very difficult times [...]. People would lose their homes in the fires. They would rebuild them and then lose them again the next year. [...] We had to help each other. If you lost your house, you needed other people to help you rebuild. It worked like that, we all helped each other. It's not like that now (2 September 2013). 
As these difficult times became distant memories, an erosion of intimate social reciprocity occurred (see also Li, 2014b). Many landless labourers described how, as tight spots and crises compelled them to take on debt, they were further compelled to pay rents and use their labour as collateral. Some had little other option, but to return to extended family holdings in Java, but for many, Sungai Lamandau was the only home they had. Access to serviceable land, was essential for life as a labourer in Terantang and Kumpai Batu Bawa. Labourers, who were paid in rice, could not otherwise make ends meet when crops failed.

The REDD+ project enabled some to launch market-based counter exclusions. Prior to the REDD+ project's establishment, Pendulangan's rubber tappers were regularly forced to sell their raw product at local markets at a loss, due to limited means to access alternative markets. The project brought an opportunity for rubber tappers to form collectives and resist the power of middle-men to set arbitrary hikes in commodity market prices. As explained earlier in Chapter four, access to REDD+ benefits were mediated through land control, labour and commodity markets. Prior to the REDD+ project, rubber tappers in Pendulangan and Tanjung Puteri worked independently of one-another and sold their raw product to middle men in the market centres of Mendawai and Sampit. Prices fluctuated daily. Utami, a member of the all-male Sepakat group stated in an interview:

I used to sell the pantung (raw rubber) that I collected at the docks in Sampit, because the market prices were higher there and my brother worked for the KORINDO [saw mill] on the boats, so he took it there for me. [...] Often I wouldn't get more than Rp4,000 a kilo, so I made a loss. [...] In Mendawai it was best to sell when it rained, because Pemantung 
(rubber tappers), don't collect anything in the rain so the price is higher. In the dry season it's very difficult. [...] We don't have anything to do with [middle men] now. They're all swindlers. They drove nice new cars while sometimes I couldn't even afford an ojek (motor bike taxi) to return home (25 July 2013).

The formation of a REDD+ cooperative in Pendulangan allowed the group to reshape the exclusionary market regime and assert their own powers to exclude. This formation enabled an effective counter exclusion - resistance to violent market exclusions achieved through the same market rationale. The act was therefore not an emancipatory one in the sense that the market-based symbolic order was peacefully normalised and reinforced, rather than transcended (Žižek, 2012). In this instance, the issues engendered in systems of private property were solved, temporarily for some, yet perpetuated for others through systems of private property. The market's violence was simply moved around (see Harvey, 2011).

The market logic of competition and individualism instilled in some farmers meant that not all small-holders and labourers in Sungai Lamandau were able to mobilise alongside others to reshape systems of market violence. Many landless labourers in Kumpai Batu Bawa, excluded from the project's market-based benefits, were accelerated towards the social margins. Their efforts to join a cooperative had failed due to the exclusionary practices of landed neighbours, as discussed in the Chapter five. Yet, the REDD+ project did offer the Tani Sejati group of Kumpai Batu Bawa training and materials to promote more 'sustainable livelihoods'. For landless farmers, this came with some violent environmental impacts. As Fathir, a male resident of Kumpai Batu Bawa explained: 
We were given the karet (non-native rubber trees) by Yayorin. They showed us how to make it 'three-in-one'. They grow like conjoined twins you see? That makes it quicker to tap the rubber. [...] I have no land. I had to sell it all, bit by bit. I had nowhere to plant my karet, so I cleared the forest at the back of my house. No-one was using it, just the chickens. [...] I still had to keep it quiet. You go to jail for clearing trees. Even the pylons are made of metal now you see? There's not even enough trees left to make pylons (4 October 2013).

The violent counter exclusions described here were hidden from landed neighbours. However, they countered powerfully the exclusionary dynamics forcing Fathir out of the REDD+ benefit sharing regime. The clearance also worked to undermine a central objective of the REDD+ project - to protect Sungai Lamandau's forests.

Violence within the REDD+ project had the effect of shaping the benefit sharing regime and development outcomes, but also shaped how REDD+ carbon markets, as a concept, came to be understood within Sungai Lamandau's community groups. Members would often gossip and joke about Pasar Karbon (The Carbon Market), both within and outside the presence of project implementers. A common witticism voiced by community group members involved the sale of carbon requiring the seller to haggle, like at the vegetable market. This had an encouraging effect on community members who had often voiced feelings of alienation from, what is often touted by its proponents as, a core 'inclusive' element of the Green Economy.

De Goede (2005; see also Bhabha, 1994) suggests that these common forms of satire have the power to transform understandings of money and finance, calling attention to values underlying economic globalisation. Resistance to rural change and its connection 
to global capital is a negotiation against dominant cultures in everyday life. Understandings of overt violence should therefore be underpinned by how meanings come about through these daily practices (Caouette \& Turner, 2009). Scott (1985) demonstrates that strategies of countering structural violence need not manifest as overt, organized, collective defiance-many such strategies avoid any direct or symbolic confrontation with authority. Stories, rumours, gossip, metaphors, folk tales and rituals can also be small acts of resistance against dominant ideas formed by those in a particular realm of power. He also observes that the sharing of stories and jokes enable ideas to be reinforced or changed. For the farmers' groups of Sungai Lamandau, the shared carbon-based satire worked to make REDD+ seem ridiculous, but also more palatable.

\subsubsection{VIOLENT DEBT RELATIONS}

For most small-holders, the complex connections between the REDD+ project and accelerating social differentiation were imperceptible. The concept of REDD+, as a means to facilitate access to local commodity and international carbon markets, was generally understood as benign. The instituting and maintenance of 'micro-enclosures' (see Tubtim \& Hirsch, 2004), which were occurring in Sungai Lamandau, relied on interventions by force, through debt obligations, to transform both private and commons land into more fluid commodities. Those at the sharp end of coercive transactions often fell into cycles of debt with only their labour to sell in order to reproduce themselves. The result was a cumulative state of social differentiation (see White, 1989) maintained through processes of structural and symbolic violence. Yet, far 
from being an interruption of the ordinary, these violences were folded into the landless labourers' 'normal' daily life.

Relations between landless labourers and landed small-holders and middlemen were common sites of struggle, as the landed extracted value from labourers through adverse pricing and debt interest. However, many labourers described these relationships as ones based on good faith. They were 'helpers' rather than 'exploiters'. The Sei Gandis group Headman was usually seen in such a light. Firman, a male Sei Gandis rubber tapper told me:

Hasan is always there to help my family when we need him. If it's for rice, petrol, money for the house, he provides it straight away. [...] Hasan is our boss because he is okay with the responsibility. I couldn't be the boss. [...] He knows when to 'pay' officials. I wouldn't even know where their offices are. You need to understand the political system or you can't get a permit (19 October 2013).

Firman was a good customer. He could afford to pay within a few days of a request. He also managed the REDD+ group's enterprises day-to-day and unlike Hasan, could pilot river boats, tap rubber and raise the group's cows. Labourers in Kumai and Sei Gandis who were less reliable as customers, often found themselves cut-off from loans, excluded from the group's REDD+ patch, and bereft of employment. Hasan was a reliable patron to his reliable customers. For those cut-off, there were few attractive options upon which to maintain a means for economic reproduction. For the most part, the less able clients agreed to provide timber, their homes or other property as debt payment. Some transitioned their livelihood strategies to urban centres, or found work 
elsewhere. But, despite the hardship it created, they usually saw Hasan's approach as reasonable and legitimate.

Some REDD+ cooperatives offered options of loans to small-holders and landless labourers. Many used the loans as modal (start-up capital) to fund small ventures, others used it to weather a crisis, buy food or cover school fees. Where debtors became over-extended, they were often forced to turn to illicit and dangerous repayment options. Agung, a member of the all-male Tani Sejati group, explained the situation like this:

Rice harvests fail at least once every three tries. The soil isn't right for it. We're forbidden from burning the fields like we used to. We have to buy chemicals. [...] When there's no rice to harvest, I used to rent from others, but now I can't. I borrowed at the arisan, and I must pay it back so I look for timber and gold on the sand flats [inside the Sungai Lamandau nature reserve]. [...] It's dangerous yes, but it's gold. I do what is required of me (19 June 2013).

Occasionally, those in dire straits violently refused to make repayments or surrender land borrowed temporarily from neighbours. These resistances to debt regimes were more pronounced where they were perceived as unjust. The game of chance deciding which farmers would fall ill, fall fowl to pests, fires or flooding, was seen as unfair by many who lost out. Following a Mawar Bersemi REDD+ meeting in Kumpai Batu Bawa, Matius, a small-holder with a very large tumour on his shoulder due to Hodgkin's disease, described how his land was fenced off by one neighbour while he was in hospital. Matius however, refused to stop using the land, which had been promised as collateral on a loan. He was effectively squatting, yet despite his inability to defend the 
claim, Matius was confident the land would remain under his control: "If I have no money I can't pay [loans] back. It's not fair and I have explained that. [...] My neighbours will not be friendly with me, but I can't pay" (10 November 2013).

For most labourers, excluded from REDD+ activities, mute docility was the response fuelled through a desire to prosper. This tolerance for inequality and structural debt violence was usually (but not always) brought about through an internalising rationalisation. They displayed a spirit of 'belum' (not yet) rather than 'tidak pernah' (not ever), as they situated themselves on a progressive timeline on which their time would come, when hard-work would pay-off and produce more favourable results.

\subsubsection{VIOLENT REGULATION}

The REDD+ project was regulated by multiple parties: the farmers groups; the project implementers - Yayorin and CCI; the local government agencies; and the project's certification bodies - CCBA and Winrock. In this complex regulatory assemblage, carbon was not the only object of governance. Livelihoods, and more specifically alternative 'sustainable' livelhoods, were also being contested. The regulatory assemblage's constituent parts had agreed to cooperate to conserve Sungai Lamandau's forests and create alternative livelihoods using REDD+, but what that was to look like and who would get to benefit was disputed.

The REDD+ project could not sell its forest carbon on the carbon market. The official project proponent - the PKB community-group - did not hold the land title, nor was the land formally registered under the appropriate planning designation, despite the group's efforts to convert the designation for carbon forestry. In this respect, 
recognition and political visibility was difficult for Sungai Lamandau's community groups to achieve. The problems they faced were perceived as grinding and banal, and failed to draw in political allies to amplify the protest. There was no visible big agribusiness in the arena; no food sovereignty issues; no indigenous rights; no transnational villains to blame. All the factors which made Sungai Lamandau a safe choice for trying-out REDD+, limited local politicians' sense of urgency for action. It had orangutans, but they were pests in the palm oil and timber trade - the corporate homeland of the Bupati (Head of the district Regency's office).

Although explicit violence was seldom observed, there were rare moments when smallholders publically resisted violent power structures and demanded their issues be made politically visible. An example of this was observed at a sosialisasi (public consultation) meeting, hosted by the provincial forestry department (BPDAS) at a large Swiss-Belinn hotel in Pangkalanbuun. The two-day event was intended to inform Sungai Lamandau's community groups, NGOs and local businesses, on the advantages of community forestry, including REDD+. Following the initial introductions and prayers, the head of Pelangi Kobar Bersatu, the community coop umbrella union, stood and described a detailed timeline of the past few years, describing the efforts of the group to form a community-based REDD+ project. He described the struggles of forming a legal entity with liability for the project, and the difficulties of establishing working groups to end a culture of forest destruction. He continued:

Why is the Bupati not here? He sends his deputy who will stay for only five-minutes to eat his cake then [as soon as he eats he will probably go 
home $\left.^{34}\right]$. [... Thank you for coming to our village and telling us about REDD+, community-forestry, and the rest. But it is the Bupati who needs to hear this. We cannot progress if he isn't listening (27 September 2013).

BPDAS, given their limited provincial powers, could not assist the group. "Happy Struggling" read the final slide of their PowerPoint presentation, accompanied by patriotic images from the Sokarno era (see Figure 6.1).

Figure 6.1: Image from BPDAS Kahayan presentation (10 October, 2013) reads: "Thank you and happy struggling".

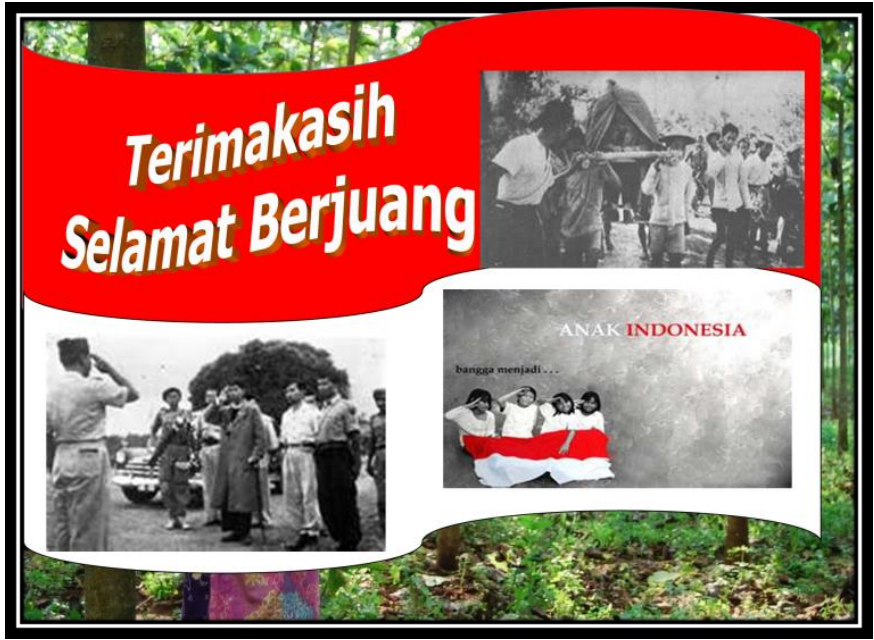

This was not one of those rare moments of political electricity which Scott talks about (1990: xiii), "spoken directly to the teeth of power". The BPDAS official's power to effect change in the District was negligible. However the message from BPDAS was clear - the struggle in question would receive no central government support. From the government's perspective, the landless labourers of Sungai Lamandau were 'out of sight, out of mind'. They could not get to the Swiss Bell-Inn Hotel and nor were they represented by others. Their condition did not constitute an event.

\footnotetext{
34 "Sudah Makan Pulang" was his exact words. The acronym SMP refers to Junior High School, and is said by students to mark the end of the working day.
} 
It is easy to draw associations between these non-events and what Povinelli (2011; drawing on Foucault, 1988) terms Economies of Abandonment. For Povinelli abandonment is the absence of state care and the intensification of social vulnerability during 'late liberalism', where life that does not produce value according to marketlogic, or when it threatens the security of the market according to market logic is "violently extracted" (Povinelli, 2011: 22). The 'extraction' for some in Sungai Lamandau involved imprisonment for illicit livelihood activities, others suffered from poor nutrition, housing and disease - nothing at all dramatic enough to warrant the Bupati's office's attention beyond five minutes of cake.

Violent regulation also took the form of forced evictions by forest police, from land within the buffer zone and nature reserve. These evictions often constructed casual forest collectors and miners as violent subjects, requiring alternative livelihoods achievable through the REDD+ project. As Ali, a male Pendulangan / Tanjung Puteri resident, stated in an interview:

Except for the board walk, the rest of Tanjung Puteri is deserted since they moved us. I still own land there. [...] We couldn't grow anything because it flooded every month, but we could easily access the rubber along the tributaries in small canoes. From Pendulangan you have to use a kelotok (motor boat), to get across the main River. I don't have one. Who is able to get money for a motor boat? Not stupid men like me. [...] I was told by the forest police once who came down here, that I wasn't allowed to collect water from across the river or they would arrest me for 'illegal logging' (said in English) - from my own land! (15 November 2013). 
The violence of promoting and regulating 'sustainable' alternative livelihoods for those evicted was both symbolic and structural (McGregor et al., 2015). These alternatives included employment as part of the projects' participatory Monitoring Recording and Verification (MRV) systems; and through the exploitation of 'Non-Timber Forest Products' (NTFP). The incorporation of the alternative livelihoods strategy was rooted in the view that local forest communities were primarily responsible for the degradation of tropical forests and peat lands across Kalimantan (Blom et al., 2010; Dove, 2011).

The REDD+ project was attempting to link income-generation (especially for the rural poor) with conservation objectives: a process known as Integrated Conservation and Development (ICD) ${ }^{35}$. According to CIFOR (2000: vi) an underlying assumption is that "a community and its members (potential entrepreneurs) will conserve and protect forest resources, if it receives the economic benefits from sustainable forest use". The implication here is that it is the forest residents, rather than large multi-national corporations, who are responsible for forest degradation with the challenge being to create 'alternative livelihoods' and make sustainable forest uses more profitable for the rural poor.

The project implementers, as regulators of the livelihood options for these 'destructive actors', advocated non-destructive exploitation of 'neglected' forest resources (see also De Beer and McDermott, 1989; Dove, 2011). The term 'NTFPs' appears to be a politically neutral reference to a portion of forest outputs, yet the regulation of what constituted

\footnotetext{
${ }^{35}$ The World Wide Fund for Nature (WWF) first introduced ICDPs in 1985 to attend to some of the problems associated with the 'fines and fences' (nonparticipatory) approaches to conservation (see Hughes \& Flintan, 2001).
} 
'sustainable alternative livelihoods', and the promotion of NTFPs was profoundly violent.

NTFPs are highly politicised on two assumptions: the first is that NTFPs are resources local people may be permitted to exploit; the second is that no-one but local people would want to exploit them, leaving powerful actors to seek out more lucrative forestbased resources, or the same resource on a more profitable scale ${ }^{36}$. The rhetorical constraints in the concept of NTFPs are reflected in the fact that these terms were never applied in the context of lucrative commercial resources. For example, there was no reason to consider mineral resources within Sungai Lamandau's forests as anything other than Non-Timber Forest Products, yet it is difficult to imagine, for instance, Kalimantan's precious metal deposits in this fashion. Sungai Lamandau's gold for example, was strictly off-limits to local farmers ${ }^{37}$.

Within the Sungai Lamandau REDD+ project, the 'expert'-driven discourse was the dominant one. The finance group, Winrock International and the Climate Community and Biodiversity Alliance (CCBA), (managed by Conservation International), had set clear regulatory guidelines for which Sungai Lamandau's MRV volunteers had to follow, with very little freedom to transgress the internationally-approved standards. Although the access requirements for many groups restricted landless actors' participation, those without private land still had the opportunity to work as MRV volunteers - investigating carbon leakage (illegal logging), monitoring of fires, and the REDD+ site's biodiversity fluctuations. Though these were unpaid positions in Sungai Lamandau, it has been argued elsewhere that participatory MRV can allow for a "mobilisation of counter-

\footnotetext{
${ }^{36}$ Dove (2011) therefore asks us to think about NTFP's as more akin to 'Non-Value Forest Products' than inherent sustainable livelihood alternatives.

${ }^{37}$ It is estimated that the volume of Indonesia's national gold production extracted legally is less than illegally mined gold (Gunawan, 2015).
} 
expertise", empowering marginal actors in unexpected ways, and thereby counteracting the regulatory ambitions of international science and policy elites (Gupta et al., 2012: 729).

The apparent symbolic violence engendered within the regulation of the project was nowhere more obvious than within the women's groups of Wanita Mandiri and Cabe Rawat. Women, formally excluded from all the farmers groups that had been allocated land within the REDD+ site, worked as kelompok suport (support workers) - preparing saplings in polythene sacks or meals for visiting development workers. Through its regulation, it appeared the project was working to concretise the prevailing essentialist dichotomies of masculinity and femininity.

However, in some villages these seemingly violent exclusions incurred by women were somewhat superficial. Whereas formal all-male meetings revolved around prayer and other formalities, it was clear that women, excluded from formal meetings were able to regulate the communities' affairs beyond monthly official assemblies. Women often dominated the REDD+ project's regulation from behind the kitchen doors. Meri, a female member of the Sei Gandis rubber tappers' community, described an example of a more intimate regulation:

They (the men) agreed that we should start a perusahaan (communal group enterprise), for the rubber and the cows. They also agreed to pay money for modal (start-up capital for the enterprise). I talked to my sister and sister in-law about it and we realised that it would be very bad. We have members who have homes very far away from here. They would take all the money. People are like that. They would not be seen again. We discussed it and we have all agreed. It's like that (14 August 2013). 


\section{4 .5}

\section{VIOLENT CONSERVATION AND DEVELOPMENT}

Well-meaning interventions in the lives of Sungai Lamandau's farmers also brought about more ambient exclusions ${ }^{38}$ - exclusions motivated by efforts to attain 'the common good', through poverty alleviation and sustainable development discourses (Hall et al., 2011: 60). Like the structural and symbolic violence of debt and market regimes within the REDD+ project, external actors who sort to enclose land for conservation, pushed for influence in some of the most day-to-day aspects of local people's relationships with land and each other. Due to the number of large-scale conservation enclosures in the region calling themselves 'REDD ${ }^{39}$, the term had become synonymous with any kind of 'Go-Green' initiative. At one SATGAS meeting in Pangkalanbuun, a group of poorly-informed local government workers discussed how cycling to work schemes and anti-littering campaigns would be used as tools to help REDD+. Furthermore, the Sungai Lamandau project specifically was understood as an extension of pre-existing conservation initiatives facilitated by OFI and OFUK. The goals were seemingly the same and the implementation strategies involved the usual suspects - a consortium of orangutan conservation charities and their supporters.

The Sei Gandis rubber collective shared a distinct sense of historical injustice instituted by OFI and their orangutan supporters. Sarwono, a male Sei Gandis member explained to me:

Sei Gandis, our group, used to collect rubber from across the bay from Kubu, in Tanjung Puting. Even when they closed the forests for the

\footnotetext{
${ }^{38}$ Hall et al. (2011) describe various unjust exclusions which occur through conservation discourses as 'ambient exclusions' - processes which promote disproportionate costs towards vulnerable groups in the name of a common good.

${ }^{39}$ Projects included the RMU Katingan project; the Infinate Earth Rimba Raya project, Sungai Lamandau and various REDD+ related activities.
} 
orangutans, we could still get in. But now we must go up river. It is as if the military are there now. They have guns and they will put us in jail if we go in those forests (1 November 2015).

Though the forest had been set aside by the Dutch colonial government in the 1930s, in the 1980s OFI had led a move to fully enclose the 400,000 hectare site as a national park. Sei Gandis members were prevented from accessing what they saw as their customary lands for the purpose of creating a pristine environment for wild primates. But, as Münster and Münster (2012) argue, the idea of a pristine wilderness disregards centuries of human interaction within forests, and serves to justify 'fortress conservation' (see also Peluso, 1992; Spencer, 1999; Brockington et al., 2006; Agrarwal \& Redford, 2009).

Although landless members of the Sei Gandis collective were clearly suffering through ambient exclusions, those who owned land, or could at least convince others of the fact, made significant gains. Due to the increasing threat of encroachment onto land perceived as vacant by large palm oil estates, OFI looked to expand their conservation efforts. In order to ensure land for the regions' orangutan projects were acquired with minimal upset, OFI regularly purchased the same privately owned plots two or three times over, from different families. Where deeds were held, land neighbouring OFI's reserves could be sold at hugely inflated prices. In November 2012, an undeveloped area less than $5,000 \mathrm{~m}^{2}$ had sold for $\$ 80,000$ (USD).

The boom sparked a rush for vacant land. In Kubu and near-by villages, land with no clear ownership attached was quickly fenced-off and offered-up for sale. It was explained to me by one Kubu villager how a family who had used a small plot of land for generations had it sold from under them by neighbours holding deeds to it acquired 
through links to political officials. Violence in the form of fighting, vandalism and occupying the plots in question were common reactions by those removed from land gazetted for conservation purposes. Resistance to violent evictions was often perceived as useless. As one male rubber tapper from Kubu told me:

Our forests are used for the prosperity of orangutans, but what about my prosperity? What about my children's prosperity? It is very clear that they care more for orangutans than human beings (18 November 2013).

Riot police from PolHut were regularly used for suppressing physical dissent. But, for day-to-day policing of the newly instituted land tenure arrangements, OFI recruited three sympathetic Kubu villagers as political commissars. They were given dark blue uniforms and tasked with ensuring that sympathies for OFI's work were disseminated amongst other villagers. The commissars included elected officials, so as to ensure maximum influence for the cause.

These violent strategies of land acquisition were deeply troublesome. To tout reserves and national park creation as an unadulterated and uncomplicated good (as many conservationists do - e.g. World Bank, 2006; Bullock \& Lawson, 2008) is misleading as they often lead to further enclosures and dispossessions (see also Kelly, 2011). The means by which protected areas in Sungai Lamandau were created, maintained and commodified through violence were leading to increased environmental violence and long term social instability.

Actors operating within transnational carbon markets may benefit from these enclosures, local farmers and the environment may not. Despite these exclusions, the REDD + project, like many of the district's development projects before it, relied on 
small-holders' presumed sense of civic pride and altruism to ensure their success. Although many school groups and other young people did volunteer their free time regularly to help the conservation effort (see Figure 7.2), many had personal commitments and livelihood priorities which took precedence.

Figure 7.2: Local volunteers and community group leaders prepare for a day of tree planting in Sungai Lamandau. The banner reads "Caring for Orangutan Week - World Tree Day"

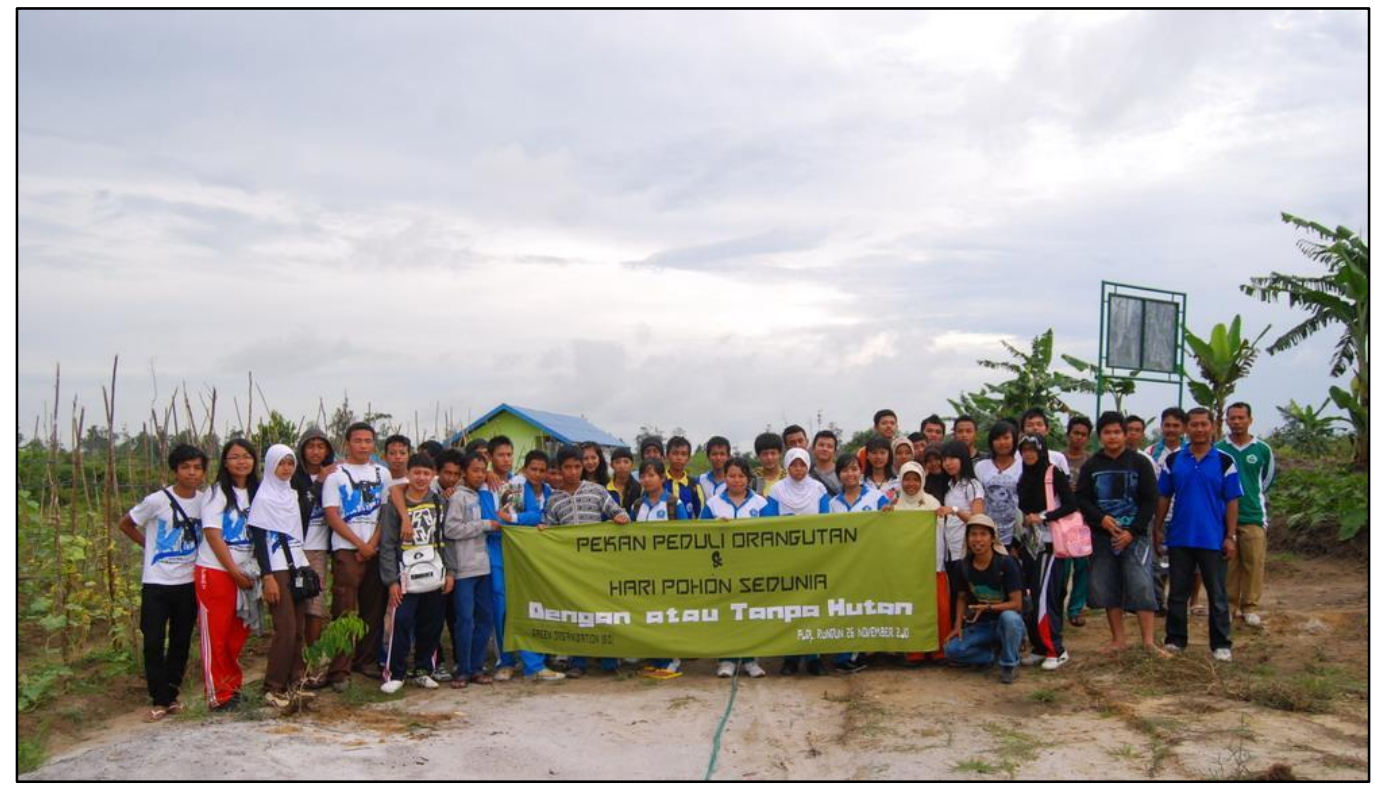

In mid-2010, to initiate the REDD+ project's reforestation effort within the buffer-zone, cooperatives were charged with planting jelutung saplings acquired by the implementing consortium and funded through the CCI forestry programme. The event was well publicised in OFUK, Yayorin and RARE's project documentation ${ }^{40}$. However, according to volunteers, very few of the 1,500 saplings provided were ever planted. According to Dumadi, a male rubber tapper from Pendulangan:

${ }^{40}$ http://www.orangutan.org.uk/downloads/Project\%20Summary.pdf 
We stored the saplings in the guard posts. They were meant to be moved to the rubber tapper's sheds on Sungai Bulu and then planted for gotong royong. Most just rotted. [...] I found them a few months later. We took the polybags off and dumped them. [...] It's a shame we don't have the time. They don't last long and if we're busy at the weekends, they're all dead (16 October 2013).

A push to expand the availability of native jelutung and rattan was perceived unfavourably by many rubber tappers, ${ }^{41}$ resulting in the series of dissimulative acts. The rubber tappers' rejection of the native species was understandable when contrasted with alternative species: Jelutung could only be tapped very early in the morning while the air temperature was cooler; trees were located up to a mile apart separated through deep swamp-land; and there was no guarantee that once reached on foot, the tree would not have been tapped by others. Instead, group members preferred the extension of non-native karet rubber species. The karet could be planted very close together; a single hectare plantation could sustain a family securely; and planting the crop on private land meant the owner had exclusive rights to it.

The dream of external project proponents, seeing a restoration of native wilderness, maintained by native labour, became short lived. Those without private land, who could have benefited from such a dream, were required to work as labourers for landed neighbours. The presumption that Sungai Lamandau's farmers had ample time to spare for forest conservation tasks was countered with dissimulation. Members of farmer cooperatives had agreed in principle to assist by whatever means necessary. Yet, behind the backs of project implementers the task was stored away and forgotten.

\footnotetext{
${ }^{41}$ Despite record high market prices for rattan, export restrictions on raw and semi-processed rattan meant that farmers were required to process the product before it could be sold internationally.
} 
There were other clear instances of what Adas (1986: 64-86) terms 'avoidance protest'. This kind of violence bypassed open dissent or direct confrontation with the project implementers, forestry officials or donor bodies. As Hendra, a member of the all-male rubber group, Sepakat, told me:

There's been two occasions when we have been given thousands of saplings. We plant some. But we must leave most of them on the floor. [...] How do they expect us, a small group to plant all those trees? We don't own the land. We can't give the land to our children. Those trees are for the orangutans not us. They would do better to plant durian; the orangutans would enjoy that more (29 November 2013).

This sort of disobedience and lack of commitment to the project's manual labour requirements was interpreted as indifference. As I have explained in Section 7.2.3, the local people of Sungai Lamandau, were symbolically constructed as uncaring Others people who cared very little about forest and biodiversity conservation, a situation desperately requiring external intervention from the REDD+ project implementers. OFUK director, Ashley Leiman stated:

It's difficult to say 'you have to protect the forests because you have to look after the Orangutan'. It's not a species people warm to. They like stories about tigers and elephants; they all know about the Komodo dragon. But the Orangutan isn't a species they're comfortable with. [...] The majority of people who live here have never been to Tanjung Puting [National Park] and they have no interest in ever going to Tanjung Puting - no interest in Orangutans. It's because of the resemblance to humans maybe or vice versa, I don't know. To get people to conserve forests you 
have to talk about timber and money and poverty, not species like Orangutans, they don't care about that. They don't value it - the way we think about the value of the forest - in that way (14 June 2013).

Yet in fact, many local people did care about forest protection. A group of selfproclaimed 'activists', in their early-twenties, met weekly at the small outdoor cafes (warungs) in Pangkalanbuun, to discuss opportunities for direct action against palm oil ventures encroaching into local forests. One of the activists, Aji, invited me to their Saturday evening meeting. He arrived with printed copies of an article from the Mongabay ${ }^{42}$ website - one for each of the ten or so members. Aji was not alone in his concern for human rights and environmental issues. Other group members shared stories they had come across featuring the US-based palm-oil giant Cargill's use of child labour on its Kalimantan plantations, or local politicians' affiliations with logging firms. But, this image of local people caring a great deal about local conservation issues was rarely shared by the international REDD+ project implementers. In their eyes, local people were the cause of Sungai Lamandau's forest degradation. Their perceived violent character legitimised the REDD+ project, but did in-turn produce a self-perpetuating logic - a cycle of violent alterity causing the very degradation REDD+ was designed to fix.

\footnotetext{
${ }^{42} \mathrm{http} / / /$ www.mongabay.co.id/2013/11/09/anggota-rspo-rambah-tanjung-puting-belulang-orangutanditemukan/
} 


\subsection{CONCLUSIONS}

Sungai Lamandau's forests, unlike the coal mines, palm oil plantations and extractive industries of the interior, were on the surface, an oasis of biodiversity, attracting thousands of tourists each year whilst sequestering countless gigatones of anthropogenic carbon emmisions. However, this chapter has argued that below the superficial yet ominous peace, were processes of implicit violence, legitimising exclusion of the already marginalised. Those excluded however, rarely disappeared quietly. Many countered their exclusion with violence, sometimes with emancipatory effect, sometimes with environmentally destructive outcomes.

These counter exclusions were intimate processes and rooted within violent histories of struggle. The four 'powers of exclusion' - Markets, Regulation, Force and Legitimation, are shown as particularly important in understanding the violences mobilised from all directions in pursuit of multiple interests. The concept of legitimation is, especially relevant here. Political memories instituted the 'rightness' of exclusive claims to things. Legitimation entrenched regulation, the market and force as politically and socially acceptable bases for exclusion. How those excluded from REDD+ benefits resisted further marginalisation was also shaped by political memories, affecting what they dreamed as possible. As Gramsci puts it, before coming into existence new possibilities must be ideally active in the minds of those struggling for change (Gramsci, 1985).

The imposition of 'alternative livelihoods' were wrapped up in symbolic renderings of Sungai Lamandau's small-holders as 'forest destroyers', requiring less destructive pasttimes. This construction of imaginaries featuring native woods gardened by native small-holders, met with significant covert yet environmentally destructive counter- 
violence, heavily undermining the project's forest protection goals. These goals deserve suspicion, because the rationalities, strategies, technologies and techniques they employed attempted to formulate violence as a meaningless or barbarous practice situated 'out there' among the destructive and unruly 'beneficiaries'. Yet, violence is never a meaningless phenomenon. Violence is imbricated in the production of space (Springer 2012), where space is a protean and relational assemblage of innumerable sites both 'out there' and 'in here' (Massey, 2005). It is the other geographies of violence, namely those of impoverishment, and in particular socioeconomic disparity, that have formed the basis of concern in this chapter.

All too often, intimate spaces and bodies are either rendered invisible or are characterised as the disconnected, passive victims of national and global processes of REDD+ implementation (Cavanagh \& Benjaminsen, 2014; Dowler et al., 2014). By thinking about the production of violences through an intimacy-geopolitics frame (Pain \& Staeheli, 2014) this chapter has sought to trouble the conventional approaches to space and scale that reinforce these invisibilities. Intimate violences and geopolitical violences are inextricably linked and indistinguishable. Sites of violent exclusion and counter exclusion included kitchens, river-side huts and rice fields as much as police stations, Bupati's offices and guard posts. Yet, whether the violence was everyday and objective, or profane and subjective (Žižek, 2008) all were related attempts to exert political control through fear, shame or guilt (see also Pain, 2014). Using the Marxist conception of moments, this chapter has tried to make sense of things.

Scheper-Hughes and Bourgois (2004) argue that there is a need to understand violence as encompassing all forms of 'controlling processes' that assault basic human freedoms and individual or collective survival. In response, this chapter has explored the grey 
zones of violence which are by definition, not obvious. On many occasions, counter exclusions between social intimates resulted in unintended consequences. The inequitable benefit arrangements often resulted in the realisation of 'lose-lose' scenarios - losses for the local environment, the global climate and security of livelihoods. Yet, the conditions under which agrarian differentiation took place were not an inevitable outcome of any social development. It took intervention through violence to exclude people from common land and transform people into wage labourers available for hire.

The following chapter will explain how those struggling to counter these processes of violent exclusion were losing their precarious foot-hold on the land, becoming temporarily or permanently 'delocalised'. A 'deagrarianisation' of rural living in Sungai Lamandau was occurring as many bid farewell to farming and forest-based livelihoods. 



\section{CHAPTER \\ EIGHT $\mid$ A FAREWELL TO FARMS?}

There are known knowns. These are things we know that we know. There are known unknowns. That is to say, there are things that we now know we don't know. But there are also unknown unknowns. These are things we do not know we don't know.

(Donald Rumsfeld, Former United States Secretary of Defence, 2002).

\section{$8.1 \quad$ INTRODUCTION}

Rumsfeld's circuitous ramble on the fallible basis for forward planning is a profound distillation of the predicaments in REDD+ project implementation. We live in the evidence age (Pawson et al., 2011). Project implementers seek to justify policy decisions on the basis of 'known knowns'. The real problem is what to make of the 'known unknowns' and the even more troubling 'unknown unknowns'. In Unplanned Development, Rigg (2012) argues that the determinants of economic and social development projects, such as REDD+, are so contingent on contexts, cultures and histories that it is often ultimately futile to attempt teasing out causal relationships between policy settings, institutional arrangements, geographical endowments and development outcomes. Events and processes that shape REDD+ style conservation and 
development project outcomes are sometimes "not simply complex in that they are technically difficult to grasp. Rather, they are complex because they necessarily exceed our capacity to know them" (Law, 2004: 6). Uncertainty is exacerbated by the difficulties in isolating people on-the-move - pursuing their complex desires with often 'irrational' strategies.

Feminist scholars have put forward evidence to demonstrate that the twin forces of land exclusion and a failure of urban labour markets to provide viable alternatives to agrarian livelihoods have together intensified the multiple vulnerabilities of Indonesia's rural poor (Elmhirst, 2012). The impact on agrarian livelihoods is seen clearly through rapidly growing inequality in land ownership. The percentage of households in the category of 'marginal farmers' in Kalimantan, with landholdings considered too small to meet more than subsistence requirements, have increased from nine-percent to fortypercent in the last twenty years (Lokollo et al., 2007). It is possible to read these changes as processes of 'deagrarianisation', representing a diversification of livelihoods that are now less tied to the land.

Yet, as Rigg (2006) argues, an agrarian crisis may have been averted through a shift in livelihoods to non-farm activities, and to economic activities beyond the village. To be sure, a dynamic class of entrepreneurial smallholders is emerging that, together with domestic investors, is deriving a lucrative livelihood from boom crops such as oil palm and commercial rubber (Hall, 2011). As these emergent 'progressive farmers' accumulate land, their prosperity is linked with problems of agrarian differentiation and dispossession. And despite this new wealth, in areas distant from the markets provided by industrial and urban centres, opportunities for livelihood diversification remain limited. As many may only adjust through 'distress diversification', it is clear 
that very large numbers of rural poor remain (Rigg, 2006; Lokollo et al., 2007). However, these agrarian changes must not only be understood as a straightforward process of 'depeasantization' (Araghi, 1995) or as a transition from land-based livelihoods to market-based ones (Igoe et al., 2010). They must be understood in all their complexity.

In this chapter I reflect on an important spectacle which maintains the workings of REDD+. That is, just as 'forest communities' are imagined as potentially environmentally destructive (discussed in the previous chapter), they are also imagined as intimately cohesive and spatially fixed. This imaginary allows for certain individuals' interests to represent the 'informed consent', which legitimises REDD+ exclusions and the opening of new capital expansion pathways into the forest.

With an intimacy-geopolitics approach (Pain \& Staeheli, 2014) comes the opportunity to expose a more nuanced 'community'. Rather than a collection of people sharing the same externally observable differences, living in close proximity, the chapter critiques the spatially fixed ideas of REDD+ communities in Sungai Lamandau by drawing on Elmhirst's (2012) conception of multi-local livelihoods. Such a conception promotes an understanding of spatial mobilities and multi-local performances that transcend unhelpfully-neat scalar boundaries. The chapter suggests that Sungai Lamandau's farmers have attempted to bridge the contradiction between needing to demonstrate legitimacy through 'fixity' (Harvey, 2005) and attachment, and the need to move to compensate for livelihood failure by creating multi-local livelihood strategies. In doing so, the chapter highlights the power of multiple 'unknown unknowns' - the serendipitous events and unexpected actions shaping REDD+ in Sungai Lamandau. 
The following section considers the means by which the 'spectacularisation' occurs - the ways REDD+ projects provide assurances of 'fixity' from among their 'forest dependent communities' and the impacts these simplifications have on developmental outcomes. The chapter then introduces the conceptual framework before using it to explore the many ways Sungai Lamandau's communities remained in motion, yet rooted with pieda-terre livelihoods and diversified interest claims.

\subsection{REDD+ IN THE TIME OF DEAGRARIANISATION}

\subsubsection{REDD+ SAFEGUARDS \& MARKET-BASED COUNTER-MOVEMENTS}

As noted earlier in this thesis, critical social theorists have framed REDD+ as a discursive and material response to public concern and pressure for environmental regulation of market interests, or what Polanyi (1944) referred to as a 'doublemovement' (Brockington, 2011). Yet, market interests themselves also constitute a powerful force behind calls for emission reduction measures both as a protection for their capital, put at risk by a changing climate, and as an opportunity for profiting through low-carbon technologies and new offset markets (Bumpus \& Liverman, 2008). These appeals for regulation have therefore originated not only from those at the sharpend of market hubris, but from all parts of the carbon forestry assemblage (Lohmann \& Bohm, 2012). As the carbon market 'pioneer' Richard Sandor (2012: 1) stated:

The good derivatives are those that are regulated, transparent, traded on an exchange where contracts balance the needs of the buyer and the seller. The bad derivatives are those that are unregulated. [...] Where there are no regulations, you have to seek out a regulator. When I started up the [Carbon] 
Exchange I called up the [Chairperson of the U.S. Securities and Exchange Commission]. I said, 'I'm going to say something that you probably never hear - I want to be regulated'.

Representatives from the world's largest carbon finance institution, Barclays Capital, have also called for tighter regulation of European spot markets in carbon because the fraud "feed[s] suspicions about the reliability" of those markets (Carbon Finance, 2010: 9). Proposals for market-based solutions to climate change are offered up within policy debates, and not separately to them, because market mechanisms rely on social and cultural practices, which implicate ways of thinking and ethical and political values (Whitington, 2012). A strong trend towards neo-liberal regulation can be found in which both national governments and non-state actors, such as transnational financial institutions play a central role (Fletcher, 2012).

It is important to acknowledge that neo-liberalisation does not necessarily equate only with privatisation per se, as critics sometimes contend. Rather, as Castree (2008) among others points out, neo-liberalisation characteristically entails not so much 'deregulation' as 'reregulation', shifting the locus of resource governance from states to non-state actors, including upwards to transnational financial institutions and downwards to nongovernmental organisations (Fletcher, 2012). Within neoliberal market-based environmental management, 'the state' is still required to create and sustain the overarching regulatory framework within which market actors engage in superficially free forms of exchange (Foucault, 2008; Peck, 2010). Thus, as Foucault (2008:132) contends, "Neoliberalism should not be identified with laissez-faire, but rather with permanent vigilance, activity and intervention". 
For carbon commodities, like REDD+, this vigilance takes on a unique form. Whereas coal, for example, can be commodified on the basis of its 'use value' (Harvey, 2014), requiring regulation to assure buyers of its perceived qualities, REDD+ carbon commodities derive their value from their mode of regulation. Their value does not come from a potential to be consumed, like coal's does. The market-based 'movement', in Polanyi's conceptualisation, and the 'counter-movement' are therefore indistinguishable and mutually dependent, as are the regulator and the producer of carbon commodities. Furthermore, whereas some buyers might want to pay extra for efficient 'clean coal' - constituting an internalised 'cultural surplus' (Žižek, 2012) - for the REDD+ commodity, its entire raison d'être is drawn from the externalised costs of other products of consumer capitalism.

Regulation of the REDD+ product's perceived qualities is delivered through a system of 'REDD+ Safeguards'. It is through this regulatory framework of safeguards that enables REDD+'s legitimacy. The market for these products exists through the safeguards' effectiveness to improve the global climate and the welfare of 'forest-dependent communities' and foster development (McDermott et al., 2012). In 2013, Client Earth produced $A$ Guide to Understanding and Implementing the UNFCCC REDD+ Safeguards. Less of a rule-book, more of a list of aphorisms, the guide lists 163 pages of safeguards with 604 footnotes ranging in scope from 'ensuring the participation of indigenous peoples' to 'biodiversity protection' and 'carbon leakage prevention'. The document states that without proper regulation, "The potential risks posed by REDD+ include, amongst others: appropriation of local communities and indigenous peoples' lands (involuntary displacement), other human rights violations, and depletion of biodiversity" (Client Earth, 2013: 17). 
A more critical look at the safeguards reveals their non-explicit wording and privileging of results (carbon capture) over social justice claims. Mirroring the UN text - as agreed at the UNFCCC meeting in Cancun, 2010 - the Client Earth guide states that all safeguard measures "should be promoted and supported" (Client Earth, 2013: 16). This does not require any new commitments, but simply states that project implementers are encouraged to "promote and support" actions that "complement or are consistent" with national forest programmes and with international conventions and agreements (Lang, 2015: 1). As the UN works by consensus, the wording is as strong as one could hope for (Romero, 2015). Despite their impotent construction, a reassuringly long list of safeguards does exist providing at least the appearance of regulation if not a meaningful effect. Yet, contrary to some analysts (Thomas et al., 2009), many reviewers suggest that there is clearly a need for further substantiation of project assumptions and expectations (Corbera \& Friedli, 2012). But improved regulation is difficult if not impossible due to the very nature of voluntary carbon markets, which are concerned with maximising carbon trading volumes at the lowest possible cost (Corbera et al., 2007). This state of affairs begs the question: if one is not compelled to, why should they spend on regulation to assure compliance with obligations that do not exist?

\subsection{2 'FOREST DEPENDENT COMMUNITIES': CONSTRUCTING A SPECTACLE OF FIXITY}

Perhaps the most explicit safeguards in the Client Earth guide relate to "the protection of rights for indigenous peoples and local communities against involuntary displacement" (2013: 38). However, the guide remains very unspecific on meaning, 
concluding that, "self-identification is the most appropriate way to establish who may be indigenous and/or a local and/or a traditional community" (ibid: 40). The term 'local communities', as used in the UNFCCC REDD+ Safeguards text (2010), is later interpreted to mean "forest dwelling local communities" (ibid: 41). The protection of these spatially fixed 'local' communities is an important action from which the REDD+ carbon commodity derives much of its economic value (Cavanagh \& Benjaminsen, 2014). In many ways, REDD+ has thus become 'spectacularised'43 (Debord, 1967) generating profits through what has been termed "spectacular accumulation" (Tsing, 2000: 139; Igoe et al., 2010: 378). REDD+ depends upon an array of mediating technologies to link sources of surplus capital with the often-distant peoples and places that it professes to conserve. In doing so, REDD+ projects rely on carbon's global commensurability achieved through a series of abstractions. This allows one tonne of carbon dioxide equivalent (tCO2e) emitted by industry in one place to be rendered as precisely equivalent to another sequestered by tropical forests. An abstraction is maintained in much the same way for the REDD+ 'forest dwelling local community'.

The imaginary of a settled peasantry struggling with limited resources in degraded forests is also part of what Dove (2011: 206) refers to as "Rain Forest Marketing". Simply by paying to off-set one's carbon footprint, one can protect the homes of forest peoples while also helping them replace 'unsustainable' forest livelihoods with sustainable production of marketable carbon commodities. Just as purchasing Body Shop's Rainforest Bath Beads ${ }^{44}$ preserves forest communities and their forest dwellings; one is just a mouse-click away from saving the climate, 'the rainforest', and the world's

\footnotetext{
${ }^{43}$ In his 1967 book The Society of the Spectacle, DeBord traces the process of spectacularisation - where authentic social life is replaced with its commodified representation.

${ }^{44}$ Skin and hair care giant, The Body Shop, have linked with Cultural Survival Enterprises Inc, to advocate for Indigenous Peoples rights and support Indigenous communities' self-determination, cultures and political resilience, since 1972 (http://www.culturalsurvival.org/programs/advocacy).
} 
poor, through strategic attachments to disingenuous sets of rhetorical consumerist claims (Sloterdijk, 1988; Žižek 2011; MacDonald, 2013;). REDD+ marketing is reliant on imaginaries of place that are tied to socio-spatial fixity. In doing so, concerns over geographical specificity are neither here nor there creating a false commensurability connecting surplus capital to potential sites of carbon production.

Communities of course are not homogeneous or naturally occurring entities (Brosius et al., 1998; Agrawal \& Gibson, 1999). The romance and convenience of 'community' has meant that simplified and idealistic notions of them have persisted in community-based natural resource management, often leading to misrepresentations and 'strategic simplifications' (Blaikie, 2006; Li, 2002). As Krishna (2004: 51) explains, in reality places do not fit the "imagined landscape of self-contained village communities living picturesquely close to the land" - a powerful recurring image in the literature on community-based natural resource management (see also Li, 2001). Furthermore, REDD + projects often require REDD+ implementers to simplify or 'black box' project localities, so that they become single homogeneous objects, capable of entering contracts and responding as 'rational' economic decision makers (Milne \& Adams, 2012). As I have illustrated in previous chapters, the implications of constructing a community collective deemed to fit the 'forest-dependent poor' profile, based on patterns of externally observable variables, is that those actors who could most benefit from the development intervention are missed.

Moving beyond this implied fixity, feminist geographers have contributed significantly to advances in understanding everyday spatial mobility as a social and political process (Silvey, 2004; Pain \& Staeheli, 2014). REDD+ scholars (see for example Lynam et al., 2007; Dauvergne \& Neville, 2010; McDermott et al., 2012) who have ignored these 
understandings have failed to imagine place in a way that is not bounded; not defined in terms of exclusivity; not defined in terms of an inside and an outside; and not dependent on false notions of an internally-generated authenticity (Massey, 1999). It appears that for many REDD+ projects in Indonesia, mobile 'communities' networked across significant distances, performing multiple subjectivities and livelihoods in messy and protean contexts is the norm, not a settled peasantry (see also Pain \& Staeheli, 2014). However, the neat construction of 'forest dependent local communities' allows for spatial regulation through safeguards - a necessary consequence of REDD+ projects because conservation, like development, is inherently spatial (Agrawal \& Redford, 2009).

\subsubsection{THE HIDDEN GEOMETRIES OF REDD+ IMPLEMENTATION}

With such enormous diversity in attributes and externally observable differences across the array of REDD+ forest users, the regulatory task of project implementers is to make people and space legible. In Seeing Like A State, Scott (1998: 137) explores how scientific forestry - the collection of social data; the mapping and measurement of space; and the codification of space (e.g. land tenure) - have all contributed to making the vast complexities of 'the local', legible to project implementers. He states:

[S]implifications such as maps, censuses, cadastral lists, and standard units of measurement represent techniques for grasping a large and complex reality; in order for officials to be able to comprehend aspects of the ensemble, that complex reality must be reduced to schematic categories. The only way to accomplish this is to reduce an infinite array of detail to a set of 
categories that will facilitate summary descriptions, comparisons, and aggregation. The invention, elaboration, and deployment of these abstractions represent, [...] an enormous leap in state capacity. [...] [F]or the first time, it allowed state officials direct knowledge of and access to a previously opaque society.

Li (2005: 384; see also Silvey, 2010a) questions this 'spatial optic'. She argues that Scott wrongly, 'posits an 'up there' all-seeing state operating as a preformed repository of power spread progressively and un-problematically across national terrain, colonizing non-state spaces and their unruly inhabitants". However, Li also argues that neither is it the case that an 'up there', all-seeing, systematising state both promulgates and observes rules, which a 'down there' populace tries to resist. She proposes a different kind of spatial lens. Rather than emphasizing the territorial 'nation state' or 'the local' as scales existing apriori, she places analytical priority on the practice of politics and people's interactions with the interventions of national governments and development institutions. Similarly, rather than taking the presence of 'the state' for granted, Mitchell (1991: 78) recommends examining the practices "through which the un-certain yet powerful distinction between state and society is produced". In this way, we can account for the prominence of the state idea, without attributing to it a "coherence, unity, and absolute autonomy" that it does not have (ibid.).

Yet, REDD+ 'benefit sharing' and 'participation' safeguards depend on a simplified scalar formation. This imaginary construction appears much like a helicopter - with all the technological expertise required inside to link potential sites of carbon production with 'global finance' - flying over a scarcely populated forest to find a 'community'. Once 
located the helicopter lands where teams of experts gather consent and signed contracts to 'improve' forest people's livelihoods.

In reality REDD+ is an idea attempting to merge from a slip-road onto a busy motorway. There are multiple 'improvement' projects attempting to do the same, trying to influence people's already planned-out lives as they speed off horns hooting, through the traffic towards their own dreams of better things. A few contracts are created; representing the consent needed for safeguard checklists, but most remain voiceless in the confusion. Yet, as Roy (2004: 1) argues, "There's really no such thing as the 'voiceless'. There are only the deliberately silenced or the preferably unheard".

REDD+ in this development grid-lock imaginary becomes less of a failed form of development, and more akin to how Ferguson (2005 see also Silvey, 2010b) describes market-based development projects: as a series of dispersed, networked fortresses, underpinned by violence-for-profit, producing a frightening 'advanced' form of accumulation and dispossession. His argument ties-up nicely with Watts's (2008) Curse of the black gold in that both examine the landscapes of violence that destroy particular places as they simultaneously enrich others. The geographies of inequality they describe, as well as that discussed in the previous chapter, are patterned according to deep historical roots as well as ongoing enclosures, invasions, and exclusions (Sheppard et al., 2009; Silvey, 2010b).

To produce more equitable outcomes there is an urgent need to utilise an alternative theoretical lens, one which can question the spatial fixity, and state coherence that does not exist. The following section describes this conceptualisation to promote an understanding of intimacy-geopolitics, spatial mobilities and multi-local performances within the Sungai Lamandau REDD+ project that transcend neat scalar boundaries. 


\subsection{CONCEPTUALISING MULTI-LOCAL LIVELIHOODS}

The conceptualisation proposed here draws from Elmhirst's (2008; 2012a; 2012b) considerations of the disjunctures between mobile lives and livelihoods and the largely sedentarist, place-based assumptions that underpin the governance of natural resources. 'Multi-locality', according to Elmhirst, is understood in both a temporal sense

- in terms of 'life geographies' and movements through different spaces - and in a spatial sense - in terms of networks with members connected together as they pursue livelihood strategies in different places.

This understanding complements an intimacy-geopolitics approach (Pain \& Staeheli, 2014). Within the conceptualisation used here, REDD+ 'communities' are shown as operational across distances, linked together by a quiet politics about belonging; interconnected through mobilities and working to connect across difference (see also Askins, 2014). Emotionality (principally the role of emotions in forms of caring) both mobilises the quiet politics that brings people together, and is inherent in their being together. The intimate is therefore foundational to and within other realms (Pain \& Staeheli, 2014).

My analysis of multi-local livelihood strategies in Sungai Lamandau is woven around three critical conceptions: First, livelihoods are understood as performances "interrelational products of particular subjects" (Gregson \& Rose, 2000: 444). Importantly, the subject is understood as the effect of power, and subjectivities such as livelihood, ethnicity, race and gender are produced out of 'performance' (Butler, 1997) as well as symbolic domains (Allen, 1999). Subjects are therefore both the product of external influences - the subjection of the state or other institutions, for example - and 
the internalisation of this subjection by the subject itself (Nightingale \& Ojha, 2013). Viewed performatively, as Clark (2003: 169) puts it, "bodies and their environment are construed as mutually conditioning and mutually transformative". These subject performances traverse the household, community and society (Krishna, 2004), and are therefore highly gendered (Elmhirst, 2012).

In this view, therefore, gender is re-inscribed through discursive and material struggles around livelihoods and natural resources, and whilst inherently unstable, through iterative repetition, it comes to appear as natural and fixed (Elmhirst, 2008). This is similar to what Maller and Strengers (2013) refer to as 'practice memory' - drawing on the concept of 'muscle memory' from the biophysical sciences, they explore the idea that livelihood practices have memories that leave an 'imprint' on a 'carrier' or performer of a practice, similar to the ways in which the fibres of muscles retain 'memories' from previous activity. People therefore 'carry' practices which can 'travel' between and across cultures, generations and living arrangements, dying off and resurging with relative ease. This conception echoes Butler and Athanaisiou's (2013) understandings of the performative in the political and dispossession beyond possessions.

The second conception relates to livelihood trajectories (De Haan \& Zoomers, 2005), which stresses the importance of temporality and the transforming structures, institutions and personal capabilities that give shape to access controls and powers of exclusions producing multifarious forms of social and geographical mobility (Elmhirst, 2010). The conception also aims to bring to the fore the extraordinary lives of ordinary people and the unexpected (but ordinary and everyday) events which divert 'expected' livelihood trajectories (Rigg, 2012). The conceptualisation rejects the idea that Sungai Lamandau's farmers always behaved as rational actors living in worlds dominated by 
costs and benefits. As Rigg (2011) suggests when people fail to behave within models and standard units, as Homo economicus should, the deviant behaviour is often explained away as a cultural quirk. The models, templates and tools are adjusted and the course continues in pursuit of certain interests. The approach used here gives adequate sympathy to the everyday unplanned and serendipitous events effecting people's lives.

By focussing on these intimate processes, it is possible to see the intense diversity of skills and aptitudes that ordinary people brought to the REDD+ project, shaping it as much (though probably more) through their own personality traits as the codified plans and safeguards of project implementers. Rather than seeing these traits as a collection of 'capitals' (Leach et al., 1999; Bebbington, 1999), this conception is used to illustrate how individuals' strategic behaviours are embedded in processes of access and exclusion to REDD+ benefits. This provides a much more flexible conceptual platform for analysing livelihoods as pathways, explicitly focusing on access to opportunities and the workings of power (Elmhirst, 2010).

The third conception concerns the diversification of livelihood trajectories. This follows the premise of 'deagrarianisation' - the observation that in many parts of rural Indonesia, people living in traditionally agrarian conditions are looking to more than the soil (Rigg, 2001) for their sustenance. Combined with the migration of working age people to urban and industrial jobs, and the reluctance of young people to consider a future in farming, it is tempting to see agriculture as Indonesia's past and to look ahead to a future in which most people have left farming behind (Hirsch, 2012). Yet, as Hall et al., (2011) argue, there is a need to understand the lived experience of deagrarianisation and the ways it shapes how farmers see their changing relationship with land. A general 
shift in people's dependence on 'the soil' is not the whole picture; or rather it must be understood in its complexity. Hirsch (2011) therefore suggests a repositioning of agrarian relations is taking place, within wider and more delocalised processes than seen in an earlier period when access to land, labour, and capital played a more significant role in shaping social as well as economic position and interaction.

The approach used here understands that people's lives are rarely observed as neat shifts of agrarian change - with 'upward' spurts of social mobility, becoming more 'globalised' or urban as they 'modernise'. Most people are not rootless, but neither are they statically anchored to particular places. Rather, livelihood trajectories are imagined here just like botanical rhizomes - webs of roots and shoots being cast out opportunistically while nutrients move back and fourth round the root system encouraging growth wherever opportunities present themselves. A fairly robust concept associated with these empirical changes in the South-East Asian countryside is Rigg's (1998) 'rural-urban interpenetration'. Rigg shows how the rural finds its way into the city, and urban money and values find their way into villages so that the distinctions between urban and rural become progressively blurred. However, this rural-urban interpenetration requires complicating, in that it fails to account for the multiple centrality (or homes) for certain highly geographically mobile groups, such as Javanese transmigrants.

Multi-local livelihoods are strategies for spreading risk and building resilience for marginal farmers the world over (Elmhirst, 2012). These livelihood strategies are a spatially extensive form of livelihood diversification, in which shared incomes deriving from social intimates are earned outside the locality. This contrasts with forms of 'postagrarian exclusion' (Hall et al., 2011) - displacement where people migrate and 
surrender any formal stake in their place of origin, either because there is little prospect for return or they no longer have access to resources there. Multi-local livelihoods, instead, are indicative of a residual attachment to particular places.

With all this in mind, the following section explores the many ways Sungai Lamandau's farmers attempted to bridge the contradiction between needing to demonstrate legitimate access and exclusionary powers through 'fixity' and attachment and the need to remain mobile to spread risks, explore opportunities or compensate for livelihood failures in various locales.

\subsection{ACCESS TO AND EXCLUSION FROM THE BENEFITS BEYOND SUNGAI LAMANDAU}

\subsubsection{WEANING WITH BITE-SIZED MARKETS}

Sungai Lamandau's recent past was not a sedentary and subsistence world, but embodied many processes emblematic of 'modernity', such as mobility, changing market relations and patterns of social differentiation. It is not this chapter's intention to suggest that the REDD+ project was causing character changes to the Sungai Lamandau countryside. It does suggest however, that the motivations behind engagement in the REDD+ project were influenced by these processes as well as other hidden qualities and happenstance. The assemblage of actors involved in the project's formation, all with diverse motivations and liabilities were constructed from the very particular ways in which the local environmental context, and personal situations intersected and interacted. 
In order to identify those actors in need of livelihood interventions (or protection from the consequences of these activities), a series of safeguards were to be implemented by the REDD+ project consortium. These kinds of regulatory safeguards had become an integral component for planning, implementation and evaluation of the ongoing REDD+ 'pilot' schemes and strategies across Central Kalimantan (Arhin, 2014) ${ }^{45}$. The Sungai Lamandau project was a testing ground for the new CCBA Social and Environmental Safeguards (SES), which aimed to limit 'indigenous peoples and local communities' exposure to risks associated with the project's implementation (CCBA, 2013). The plan therefore was to provide a space of exemption for Sungai Lamandau's farmers, devoid of land-market risks.

People could practice their 'traditional' livelihoods free from risks of displacement and external capital interference - a communal fix to manage local dispossessions (Mulia et al., 2010). The fix echoed Li's (2010: 385) assertion that this kind of collective landholding has, more often than not "been imposed from outside, first by paternalistic officials of the colonial period and now by a new set of experts and advocates who assume responsibility for deciding who should and who should not be exposed to the risks and opportunities of market engagement."

It has been shown through analysis of REDD+ contract negotiations in Indonesia that 'location' and 'individual preferences' (time and risk preferences), not opportunity costs, play a significant role in decision making (Skidmore et al., 2014). Risk-taking behaviour was contingent upon hidden characteristics. For many Sungai Lamandau residents there was no need to take risks in order to accrue potential benefits. This was

\footnotetext{
${ }^{45}$ Arhin, 2014 provides an analytical framework -REDD+ Safeguard Spectrum- to unpack the various principles, initiatives, measures and interventions being designed as safeguards to achieve the various social goals of REDD+.
} 
a 'community-based project' where certain actors (usually landed farmers) could be completely sheltered from the risks whilst holding a monopoly on potential benefits. In Mendawai Sebarang for example, many people expressed a willingness to take part in the REDD+ project and had taken the steps to form legally-recognised groups to ensure that members would have an opportunity to access future project benefits. Yet, none had a current or previous livelihood connection with Sungai Lamandau's forests. The groups did not exist outside of the Kepala Desa's office, who stated once in an interview:

We've formed four groups; one under each Rumah Tangga (RT neighbourhood official). Each group has twenty-five men. [...] I can't remember who is in which group, I'm sure the RT's have that information. [...] We don't have any regular meetings yet. It's far too early. We don't have woodsmen in the village, just rice. Some work at the KORINDO mill. [...] We will have meetings and learn forest work once the Bupati has granted the licence for the REDD+ project. [...] I have a saying: When you build a house, you don't build the roof until you've built the walls, do you? Isn't that right? (2 July 2013)

Where benefits were temporally distant, groups formed on paper, but not in practice. Just one of Mendawai Seberang's four RTs knew about the REDD+ project's existence. The difference in group structure was clear. Active groups, who had worked to protect Sungai Lamandau's forests for years, like those across the river in Mendawai were structured outside of the prevailing Kepala Desa system. The tree nursery and gardening groups, Danau Seluluk Jaya (DSJ) and Cabe Rawat, reflected a communal lifestyle that had pre-existed REDD+ and other external conservation interventions. 
Cabe Rawat had formed through the local government's rural food and nutrition programme. DSJ had formed in order to receive financial assistance from the Agriculture Bureau (Dinas Pertanian) in the early nineties. Almost all female members of Cabe Rawat had husbands or close family members in DSJ. The groups' communal conservation efforts, tree growing and planting, were not an observable feature of groups in Mendawai Sebarang. As Adinda, a member of the all-female Cabe Rawat group told me:

They don't have community groups across the river because they want to have their wages without doing any work! But really they don't take part in the project because they don't know anything about it. [...] They work in Pangkalanbuun or on the river, not in the forests and the fields. [...] I don't understand why they've been asked to join in. It's not going to be worth our effort. If we have to share out the timber and REDD money between hundreds of groups, what then? They shouldn't take all our wages.

One of the plan's main development objectives was to promote a rural transition away from a dependence on development funds, towards 'sustainable' alternatives (Yayorin, 2009). Many compared the REDD+ project with other on-going 'community empowerment' initiatives, such as the World Bank funded National Programme for Community Empowerment or Programme Nasional Pemberdayaan Mandiri (PNPM). The PNPM project aimed to "unlock the potential of marginalised communities by empowering them to become more self-reliant and creating opportunities to improve their socio-economic conditions" (World Bank, 2013: 1). As Siti, a female member of the Wanita Mandiri group stated: 
Our [REDD+] group is like the village PNPM group. They have an arisan (communal savings and loans) and they have small businesses which they run together. But PNPM arrived with cash from the first day. And everyone can see how the money gets spent. They put all the information on boards (see Figure 8.1). [...] REDD+ says there's a 'bonus': We can't see that. There's no need for boards because there's no money.

Figure 8.1: PNPM information board relating to an erosion mitigation project

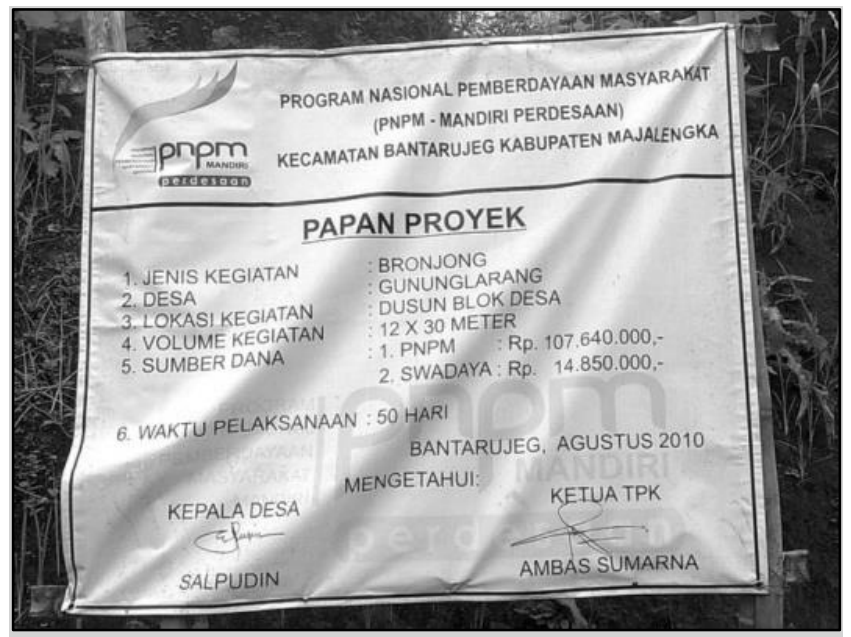

The 'self-reliance' stimulated through REDD+ required the merging of two opposing logics. The first suggested that promoting local entrepreneurship, income generation schemes and small-businesses would lead to socio-economic empowerment for marginalised groups; The second suggested that local small-holders were victims of capitalist processes intruding from the outside, and should therefore be protected from capitalism by managing their lands in common. As Yoshi, a Yayorin staff member once explained to me: 
Many people here in Kalimantan do not understand money. When they get it they spend it on silly things. They get themselves into trouble sometimes. It's crazy. They're like children. We gave out transport money at a programme visit once. We had people asking for Rp10.000 instead of Rp50.000, because they want the red note, not the blue one and they could buy cigarettes with the red ones. Serious!

Put together, these incompatible logics formed what Davis (2006: 181) calls the "microcapitalism" of the poor - a walled economy, protected from the alluring viciousness of capitalism in its global form. Yet, the REDD+ project's proposed small-scale capitalism described through terms such as 'self-reliance' and 'local entrepreneurship' ignored the micro-processes of dispossession that such a capitalism generated. After all, any capitalism is an assemblage of elements, practices, and processes with a history of violence and struggle. "We cannot tame it by building walls or wishing it away" (Li, 2010: 400).

The safeguards on trial to protect Sungai Lamandau's farmers from the risks, both sides of the wall, included, 'do no harm' principles (e.g. minimising displacement); and 'do good' principles (e.g. increased participation in decision-making, equitable benefit distribution, poverty reduction and addressing issues of tenure and resource rights) (CCBA, 2013). Though these principles may be useful, very little attention was paid to the slippery and potentially incompatible nature of these various safeguards. It is on this basis that the normative goals espoused by the concept required disaggregating and unpacking if they were to avoid disastrous reactions.

Yet, it was clear that the proposed audience for the project implementers' good intentions were not static, motionless or waiting for deliverance. They had dreams and 
were actively pursuing them. The pursuit of positive change was occurring without need for further incentivisation. Some livelihoods remained localised; others delocalised - stretched across space and between sectors. In some cases this delocalisation influenced a general 'deagrarianisation' of rural living. For those whose means of economic reproduction remained set in the immediate locale, their livelihoods were nonetheless undergoing diversification, disturbance or upheaval.

\subsubsection{UPHEAVAL, DISTURBANCE \& DISPLACEMENT}

Livelihood diversification was occurring in Sungai Lamandau both through a pursuit of diverse economic opportunities (otherwise known as entrepreneurialism - see Knight, 2013); and/or as a coping and risk mitigation strategy pursued in response to various types of shocks, and uncertainty more generally (see also Baird \& Leslie, 2013). The later pursuit was tied up in many things, including: a general erosion of social ties; a reduction in reciprocal exchanges between households; increasing trends in private land tenure and use; and general historical trends toward or away from agrarian lives. Moreover, dependence on only one economic sector was risky.

The process of arranging appropriate incentives for each livelihood grouping was defined more by chance and turbulence than planned direction and intent. Many of the project's participants sustained themselves through a mix of both agricultural and nonagricultural employment. Many were unwilling to entertain the prospect of relying on Sungai Lamandau's carbon forests as a full-time livelihood alternative, mainly because they were reluctant to undertake any one single profession full-time. The livelihood strategies of the project site's residents were insufficiently explored by the project 
planners, which had significant consequences, both positive and negative, in terms of who got to benefit and who was excluded.

Like in many parts of Central Kalimantan, as already discussed in previous chapters, the principal threat to Sungai Lamandau's carbon stocks was perceived by the project implementers to be oil palm plantation expansions (Mulia et al., 2010). Project planners attempted to dissuade local residents from the potential opportunities these large scale expansions brought by offering livelihood alternatives that were considered more environmentally benign. Yet, many group members opted for both, incorporating the new opportunities within their existing livelihood mix. As Ariep, a member of the allmale Sepakat group stated:

I met my girlfriend on facebook, but she lives in Jakarta. We've never met face to face. We speak every day on the phone and we text. She's agreed to marry me if I save money for her father and the wedding. Three years I think it will take till we're married. Then she'll move to Pendulangan and we'll start a family. [...] I have to work picking oil palm so I can get enough money. I work tapping rubber and at the real estate office. I work very hard. [...] I start work at the oil palm plantation at seven. We must line up in rows like soldiers for a morning briefing. Then I load the sawit onto trucks until two or three o'clock. [...] I will quit in July. They don't give you any time off for Idul Fitri. No bonus either. I will just quit because they only pay Rp80.000 a day. [...] I also work as a driver for a mine in Gunung Mas. [...] I paint the office of Citra Borneo Indah (another oil palm outfit) every few years with my brother. [...] Occasionally I take jobs in Sampit at the timber docks. 
Sometimes I have many more jobs. [...] Once we are married, I will work in the garden. Just that, nothing else (5 June 2013).

Some REDD+ supported groups became connected within extractive industries. The DSJ group for instance, which produced most of the REDD+ reforestation projects' saplings, also produced oil palm saplings for small-holders and larger plantations at the CCI funded nursery. For some members of DSJ, the REDD+ project was providing an additional source of financial support while they continued to sell their labour to extractive industries. REDD+ livelihood-benefits offered convenient social safety nets and potential 'bonuses' - REDD+ cows, REDD+ prawn crackers, REDD+ mustard greens, REDD+ nipah sugar, REDD+ oil palm. There was no either-or: benign and destructive livelihoods were almost always embroiled together.

Encouraging a dependency shift towards more benign livelihoods was problematic as the 'marginalised groups', who could potentially benefit from them, were difficult to identify. As Yayorin programme volunteer, Agun explained:

The people here, who have come from Java, they moved here to work in the forest for the timber. Now many of the timber mills are closed because all the big trees are gone. We have to change their minds about forests as just timber. We need to help them find prosperity outside the forests (14 July 2013).

This plan presumed the people in question had not already found prosperity elsewhere. After all, the large timber concessions had been closed for over ten-years. Two exloggers, now senior engineers at the PLN electricity company, joined the Setia Kawan REDD+ community group and worked as rice farmers and fishermen at weekends. Most 
members of the group had two homes: one located in the urban centre of Pangkalanbuun, the other a 'rumah bobrok' (dilapidated shed) in the village. Targeting those who should have access to additional sources of REDD+ prosperity was a near impossible task.

There were occasions when serendipitous planning around the un-opened black-boxes of diversified livelihoods lead to misfortune, both for the REDD+ planners and the project's proposed beneficiaries. To ensure the project site's carbon stock was protected from natural and human induced fires, for the full proposed project term of thirty-fiveyears, the BKSDA (District Nature Conservation Office) provided fire equipment to the Pendulangan village and training to members of its farmers' cooperatives. Yet, due to misunderstandings around the diversified livelihood patterns of those villagers, and gendered assumptions about who should be able to access technical know-how, most of the rubber tappers trained in the use of fire-fighting equipment were absent from the village when fires were most likely to occur. As Budiarto, a male Pendulangan villager told me:

During July to October, its dry season, that's when the sea prawns can be caught. Not the big freshwater ones in the estuary; we can catch those from the jetty. [...] All the boats go out to sea for days, sometimes weeks. Many of the men are gone. Just the old and the women and children are left behind.

On 28th September 2013, a house fire, caused by a tipped mosquito repellent coil, spread to neighbouring storage units and surrounding forest. The women of the village, who were not the targets of BKSDA's fire-fighter training, responded by moving valuable items from the adjacent properties as well as suppressing the fire with buckets of river water. Some knew where the water compressors and hoses were stored, but no 
one knew how to put them together. After a number of hours the fire was brought under control. Over the following days, many of the fishermen returned to find the grim result of the project's oversight; their homes and livelihoods destroyed (see Figure 8.2).

Figure 8.2: Residents struggle to operate water compressor during a Pendulangan fire (Left) ${ }^{46}$. Aftermath of the Pendulangan fire (one-week later) with forest, homes and storage units destroyed (Right).
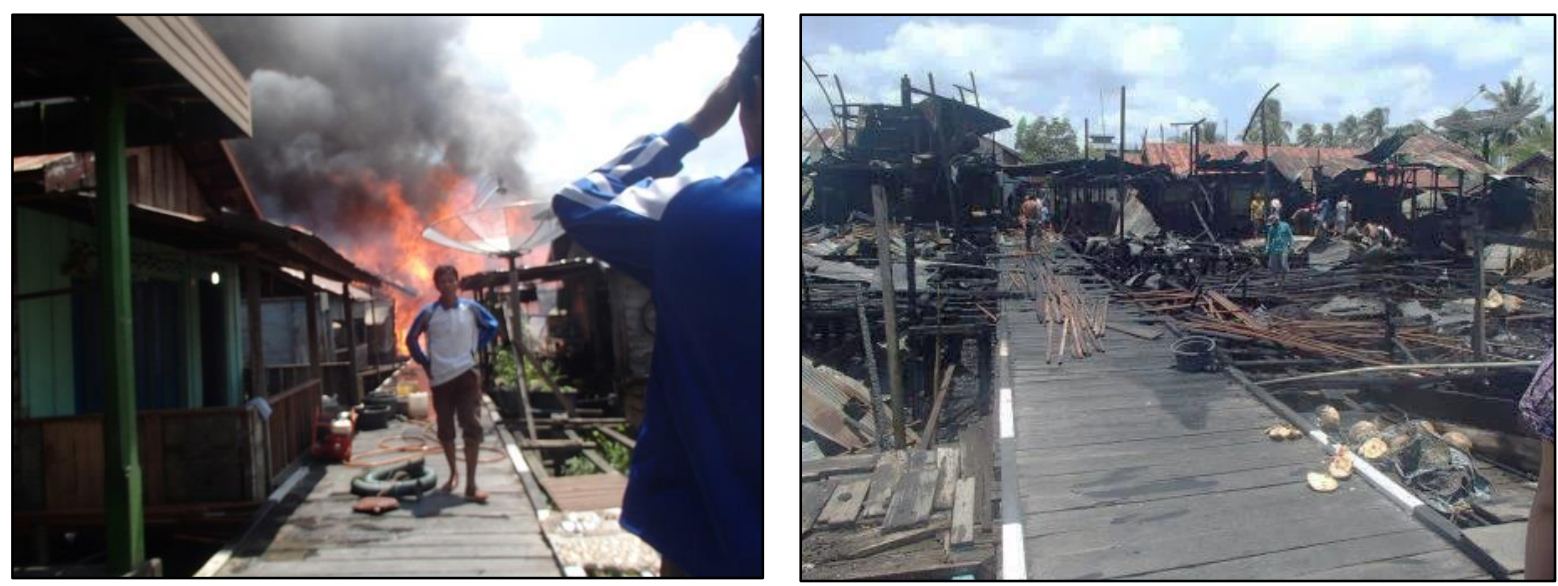

\section{4 .3}

\section{TRAVERSING LIVELIHOOD NETWORKS}

While rural life for many farmers in Sungai Lamandau was undergoing diversification, many others chose to exit farming altogether. "Exit is the standard remedy for impoverishment proposed by development planners", argued Li (2014b: 167). The socalled 'creative destruction', as rural agricultural workers transition from agriculture to industry, country to city, and peasant to entrepreneurial farmer or wage worker, is a necessity upon which economic growth, productivity and efficiency are seen to depend (Li, 2010). This 'deagrarianisation' was made up of a variety of strands: a decreasing

\footnotetext{
${ }^{46}$ Like many other villagers, I helped the best I could to extinguish the fire. I did not just take photographs as the above images might suggest.
} 
role for agriculture in rural peoples' occupations and income sources; social reidentification, as people come to think of themselves less as farmers and imagine futures outside agriculture; increased movement between rural and urban areas; and spatial reinterpretations, as urban and rural land uses became increasingly intermixed (see also Rigg, 2009; Hall, 2013).

There are stark pictures of deagrarianising communities across Indonesia. Rice cultivation, once an important rural pursuit, has seen a significant drop in prominence. It has been estimated that just seven per cent of the total population of Indonesia are engaged in rice production (Warr, 2005). Rigg (2001) shows how this change occurs not only at the national scale, but in rural areas themselves. Despite little correlation between engagement in primary food production and food security, the REDD+ project aimed to promote local self-sufficiency.

The REDD+ project was focusing on local independence, capacities, institutions and assets, hoping to create opportunities for Sungai Lamandau's farmers in traditional agrarian industries. However, the plan seemed to be overlooking the propelling force of obvious deagrarianising processes. These processes were playing an instrumental role in livelihood choices prompted by developments occurring far away from the REDD+ project site.

Despite the project planners' efforts, it was clear that many local commodity producers were looking to get out of agriculture themselves and hoped their children would not follow them into agrarian livelihoods. As Buwono, a member of the men's Sepakat rubber tappers collective told me: 
I do [jelutung rubber tapping] only to pay for my children's uniforms and books. If it weren't for them, I wouldn't do it. If they want to grow up and be like me and work in the forest, then that is up to them. But I will not pay for their school fees. I would be wasting my money and wasting their time (4 September 2013).

Budi, a member of another all-male group, Sei Gandis, faced an added imperative to get out of agriculture:

I have two girls. They can't do what I do here and my mother won't be around forever to take care of them while I work. We will need to move to the town when the girls are old enough for junior high school. They will have to do well at school and get good grades. It is like that for girls. They don't have the stamina so they must be smart.

Creating a shared commons also brought an unforeseen threat of pulling children out of school. One male jelutung rubber tapper, Harto, had abandoned a basic education in favour of following in his father's agrarian foot-steps:

I used to work in the oil palm plantations, but it's very boring and they are very bossy and strict. If you are late they will fine you. I was always late. [...] My parents would not pay for my school things, because I did not want a government job. I wouldn't be good at office work. I'm not disciplined enough. [...] I like working in the forest because I am the boss! My father and I work together. I don't need school. In the city you must have that, but the forest will always be here for us. 
Harto's decision to leave school and resist deagrarianising forces put him in a somewhat precarious position with limited resilience to shocks, should the forest not always be there. Yet, the REDD+ project supported his livelihood, in the short term at least. This self-sufficient livelihood however, could become incompatible with preparedness for other eventualities.

The project implementing consortium comprised multiple nodes with often competing interests. While CCI focussed on improving livelihoods within traditional forest industries, local government departments, including BKSDA were using the REDD+ project to assert further regulatory control. Rather than promoting forest-based livelihoods, this restructuring had a deagrarianising effect on rural life. Prior to the formalisation of farmers groups under the REDD+ umbrella, rubber tappers and other forest users in the Pendulangan village were viewed as informal gangs. Rahmat, a BKSDA and PolHut (Forestry Police) officer described the situation:

We do training exercises in the communities, weaning them off using the protected areas and the buffer zone by using the permit system and we work with PolHut to enforce the rules. There's some resistance always. There are areas where miners enter the protected areas around Babual Baboti. But we can't do much about it. [...] With the entry permits, they are valid for just six months. They can't be handed down to children and they have to be renewed by the permit holder, which is usually the group leader. So the numbers of forest users will always decrease. [...] Yes there's resistance. Gangs still use the forest like they always have. The maps show the boundary, but not on the ground around the whole perimeter. There are slightly taller trees inside the protected area but that's it. [...] It's difficult to relocate people, because 
there are few alternatives. And people don't want to be moved and they won't. [...] Protected areas always have a restricted use area (a buffer-zone), where people can access, but not cut down trees or start fires. People don't know what is actually protected and where the buffer-zone is. That is good. We can protect it better if people are kept outside. People are very poorly educated around the buffer zone and they don't understand the new roles. So we have to wean them off forest livelihoods by using the buffer zone. [...] We are part of the REDD+ project, but we're not for or against the goals of REDD+. We do as we are told (25 September 2013).

The restructuring allowed for the imposition of special conditions on farmers and rubber tappers. On BKSDA's books the gangs' customary lands had been reclassified and incorporated within the Sungai Lamandau reserve. New access regulations were imposed: access rights could no longer be inherited from parent to child, as they could within the previous informal system; leaving the group for a period of time disqualified the member's right to enter the reserve; and access permits became centrally controlled by the group's secretary. The price for arranging the gangs into ascertainable cooperatives was that many were driven out of the forests entirely and into something else.

There were other drivers of deagrarianisation outside the consortium's control. Upstream oil palm, and the associated acidification of waterways and soils, was making life downstream increasingly difficult. Many of Terantang's Transmigrant farmers were giving up land, sometimes leaving it for a fraction of its original market value. As Faisal, a male Terantang farmer stated in an interview: 
Life was very difficult when we arrived and it hasn't improved a great deal. [...] When we first arrived, there were big nila, emas, patin [fish]: but not now. The really bad floods have stopped because we have the drainage canals. But, we cannot wash in the river, definitely cannot drink from it. You would be very sick. The fish are gone. They have swum away, back to Java I hope. We can catch them there (16 August 2013).

Rice harvests were said to be successful once every three attempts. The village's coconut groves had been stripped for wood and, like elsewhere; riverine fish stocks were heavily depleted. Yet, as many villagers were returning to their family plots in Java, through bankruptcy, poor health or just frustration, other actors were quick to pick up the benefits. The outward exodus of Transmigrants meant land prices were kept low. Swathes of land could be brought up cheaply by developers; often for rubber plantations, sometimes for palm oil, but more often than not kept idle until things improved and better prices could be secured.

\subsubsection{INCREASING MOBILITIES}

While household footprints may have become more problematic and less neatly identified, understanding the household and the family remains acutely important (Rigg, 2007). Households are not inert units or proxies for families (Brandon \& Hogan, 2008). Their structures and functions are reflections of development forces. Developmental outcomes are contingent on household adjustments (Rigg et al., 2012). The REDD+ project implementers use of spatial proximity as the basis for defining the 'household' became problematic when ascribing credit for these developmental 
outcomes. As the geographical limits of Sungai Lamandau's farmers' livelihood strategies stretched and contracted, for many, the villages had remained a place of residence, but not a place of work.

The mobility of women's livelihoods especially was overlooked by the project implementers. While they understood rural areas of Kalimantan as conservative and traditional, the actual social norms and acceptable practices for women had created unseen opportunities. Women's work had become generationally differentiated; household income sources had diversified into a range of farm and non-farm activities. Many members of the project's women's groups lived multi-local lives spending weekdays with children in Pangkalanbuun or Sampit, coalescing again for Friday prayers at rural mosques, and then spending weekends in the villages tending to private land interests. Their REDD+ enterprises were weekend hobbies to some, used only to maintain ties within the community. As Yuli, a member of women's Wanita Mandiri group told me:

It would be nice to get some more support for the group, like money or a vehicle. It is our hobby. All the ladies enjoy meeting up, cooking together and drawing. I would not like it to be very serious. If we have an agreement with Citraland and a big supermarket we will need to 'up-scale', like a factory. I don't want it to be like that. As long as it all pays for itself and there is sugar and prawn crackers left over for events and parties, we will be happy with that. [...] I have my children and mother in the town. I can only come to Pendulangan twice a week at the most. I can't commit to very much here in the village these days (01 November 2015). 
As part of the REDD+ project activities, seven members of the Wanita Mandiri group flew to Lampung, South Sumatra for nipah sugar training, funded by CCI through a Yayorin project grant. The aim of the activity was to provide the women with a means to bolster their 'household economy'. When summarising the sugar enterprise to outsiders (e.g. project staff, local government workers), members also stated that the sugar project enabled additional income streams: "We formed the enterprise to support our husbands", the Wanita Mandiri group leader explained during a CCI visit to the village. Yet in private conversations, group members explained the many other benefits that came with it. I was told by a group member with four young boys: "I like to feel independent. [...] I can leave the children with my mother and go off for a while jalanjalan (walking/travelling)" (1 November 2015). Although private land held by a family in Indonesia is generally held in the husband's name, the group acquired a patch of nipah forest, held in their names (see Figure 8.3).

Figure 8.3: Members of Wanita Madiri collect nipah sugar in Pendulangan (Left). Members of Wanita Mandiri cast nipah resin into moulds for sale at local markets (Right).
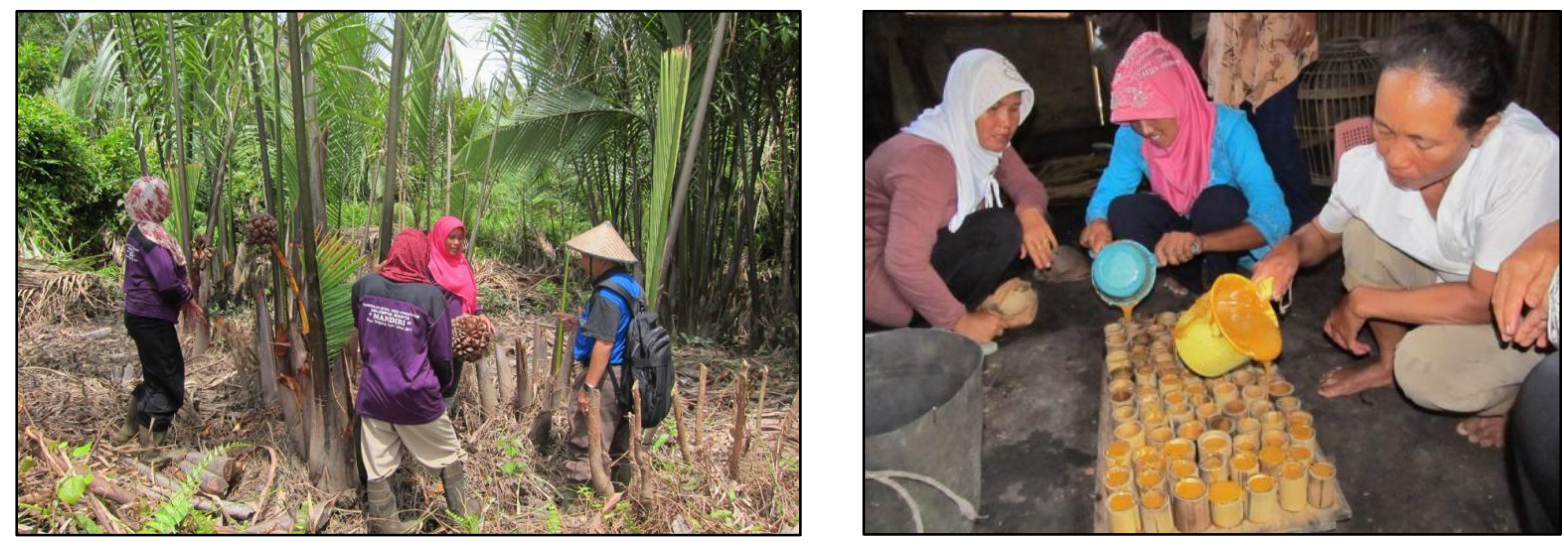
The REDD+ project's aim was to create thriving profitable businesses - sustainable alternative livelihoods for women - the result was a rejection of imposed microcapitalisms. While the geographical locations of work for an increasing number of women had become spatially dispersed, the nipah sugar project allowed Wanita Madiri members to tighten social cohesion and reciprocal relationships, which could otherwise have become increasingly transient and easily eroded.

In some respects the gendered spaces of Sungai Lamandau's women's groups were underexplored by the project implementers, in part due to traditional exclusionary gender arrangements, but also because project implementers failed to incorporate them as fully as mens groups. Men were assumed to be the workers of the household and on that basis were perceived as the families' destructive sharp edge. The traditional realm of Sungai Lamandau's women was perceived to be the home. Home-industries and assistance with managing the household economy was therefore considered the most appropriate intervention within the common purview of women's lives. Yet, as Hera, a member of the Wanita Mandiri group told me:

I have not [joined the group] for the money. [...] I want to learn English and find a good job in Singapore with my uncle. The Yayorin people are very good people. They help us with the enterprise and that's really useful for us. [...] We can't support our families with [the nipah sugar enterprise]. I work in town for that. This is just for weekends. It's just pocket money (19 October 2013).

Women were being ascribed with risk-averse qualities, entrepreneurial propensities and responsibilities for the care of the household. As Rankin (2013) suggests, these qualities inhere in an expectation that women in agrarian subsistence families are 
subjects of development who will invest their capital in productive enterprise, generate income, and respond effectively to disciplinary technologies. However, the women and men of Sungai Lamandau rarely displayed such levels of capitalist ambition through REDD+ schemes. Their dreams for the future often lay elsewhere.

\subsubsection{REGULATING LIVELIHOOD BOUNDARIES}

A racialised paternalism provided the REDD+ project implementers with a ready rationale for establishing the boundaries of their interventions: groups deemed independent, self-reliant and empowered need not have access to the project's benefits. These groups included the 'indigenous' Dayaks predominantly located in the neighbouring Kabupaten (political jurisdiction) of Sukamara. KoBar was therefore an easy location around which to draw a boundary line for project benefit exclusions, as no carbon stock additionality could be verified past that point.

The Sukamara villages of Tempayung and Babual Baboti, which bordered the REDD+ project site were dominated by a mono-cropped landscape. Land holding in Tempayung rarely equated to self-sufficiency or independence. The village was flanked on all sides by oil palm plantations. Populated almost entirely by Dayak farmers, the community had given up their communally-managed land to a plantation company. They conceded this demand on the understanding that they would become the contracted smallholders (the 'plasma') attached to the estate's 'nucleus' or core ${ }^{47}$. The plantation also promised a road to Pangkalanbuun; even if no other benefits came, markets would be just thirty minutes away by motorbike. However, flaws in the scheme became immediately visible.

\footnotetext{
${ }^{47}$ See White, (1999) for a more thorough explanation of nucleated land holding strategies in Indonesia.
} 
The plantation expanded onto villagers' land without compensation, effluent was allowed to ruin downstream rice fields and fish ponds, and did not initially include any smallholders on contracts. Instead, jobs were taken up by Transmigrants from Terantang and transient workers from Kumai. The promised road to Pangkalanbuun never came, but this did not stop the village's young people from leaving.

A problem raised repeatedly by people at the receiving end of large-scale land acquisitions is that jobs were few, and they were often filled by migrants (World Bank, 2011). As pointed out by Li (2012: 286), this is not a coincidence. "In Southeast Asia, plantations have routinely been bad news for the 'locals': their land is needed, but their labour is not". Local communities were dispossessed in order to remove the difficulty of extracting consistent, cheap labour from people who still have access to other lands, hence other options.

Introducing indigenous Dayaks to the REDD+ project was considered by the project implementers as risky. As Ikal, a Yayorin project officer stated:

The REDD+ project doesn't have any Dayak groups that live in Kotawaringin Barat district. You have to live and work in Kotawaringin Barat to join. It must say that on your KTP [identity card]. [...] We have a demonstration activity up the river to help the Dayak people there in Tempayung in Sukamara district. [...] If we include Dayak people in the REDD+ project here we have to consider 'indigenous rights' (spoken in English). We will have to include AMAN. The project would become very complicated. If things went wrong people would say we did not consider the 'indigenous rights' (16 July 2013). 
In order to keep things less complicated, the project boundary was set within a single administrative area - Kotawaringin Barat. This approach to REDD+ implementation has been labelled around the world as the 'jurisdictional' or 'nested jurisdictional' approach (Bernard et al., 2014). The advantages of such an approach include the ability to allocate future financial carbon benefits within a single tier of sub-national government. REDD+ activities can therefore be 'nested' within the national government framework so that REDD+ revenues can be allocated more effectively (Nepstad, et al., 2013). In an interview with the Jakarta Post newspaper, Head of the Forestry Ministry, Heru Prasetyo said, "For us in Indonesia, the jurisdictional approach for REDD+ should be realised nationally and implemented cross-functionally through district and provincial governments" (Jong, 2014: 1). In a bid to widen the implementation of the jurisdictional approach, the Indonesian REDD+ Agency (BP-REDD+) launched a document explaining what the approach was and how the country could implement it (see Figure 8.4).

Figure 8.4: Options for capturing and distributing international REDD+ incentives

(adapted from Conservation International, 2013)
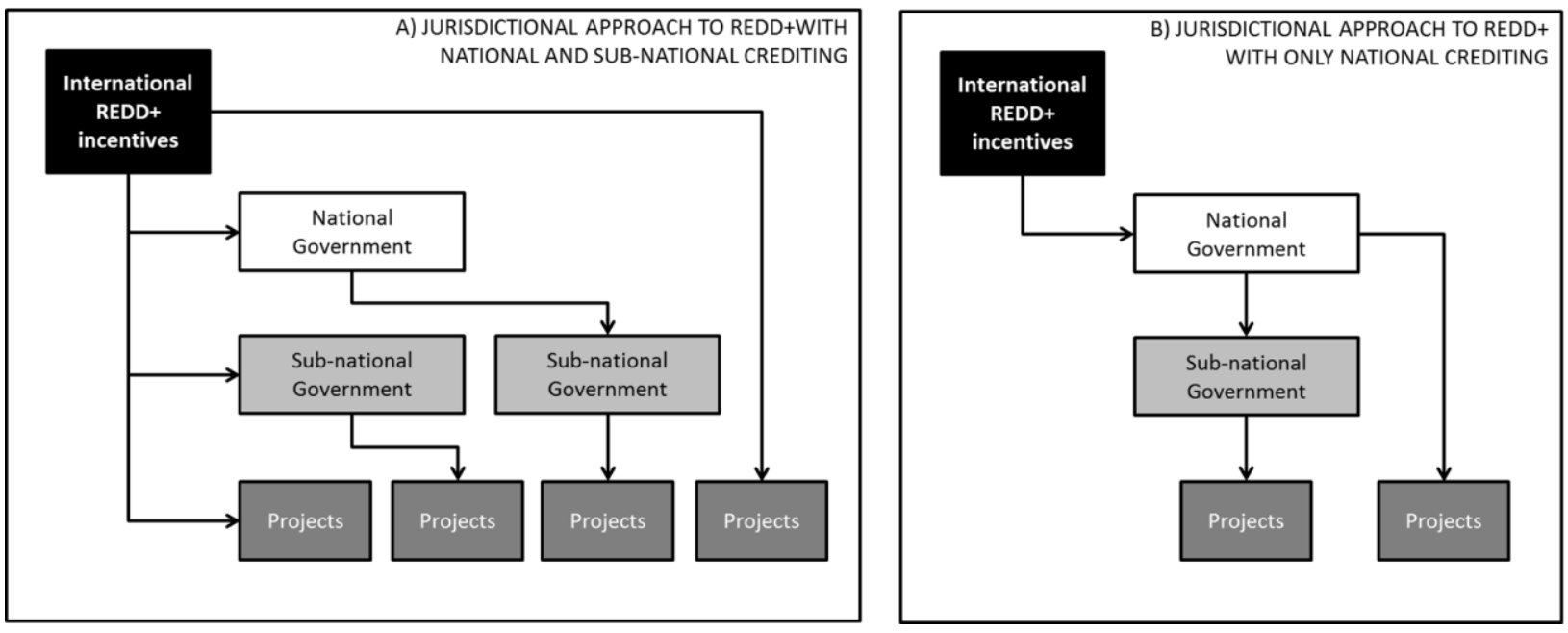
Despite its advantages, the approach limited incentives to the men and women of Sungai Lamandau who did not generally organise their lives within mapped jurisdictional boundaries. REDD+ 'bonus' payments were to be channelled to group members within Kotawaringin Barat as an incentive for protecting their forests. Yet, according to some government officials and NGO staff the main culprits of destructive practices within the protected area were citizens of Sukamara villages who were excluded from the project.

Ashley Leiman, Director of OFUK told me:

We've had all the stakeholders, even the villages and religious leaders sign up to our management plan. The arrangements are not perfect. There are still villages in Sukamara that are very resistant to the [Sungai] Lamandau project as a whole. Babual Baboti, where the gold mining takes place, they feel that it's their land - a huge chunk of it - so they're very resistant to [Sungai] Lamandau. There's conflict over where the borders are, even though most of the time it's in their interests. They've had training, demonstration plots and so on. [...] I think things can change to end the tide of deforestation, but the people coming to [Sungai] Lamandau and destroying it, the oil palm, the mining, come from all over the world or from communities in other parts of Kalimantan even. How can a REDD+ project that incentivises only the people living in [Sungai] Lamandau, how can REDD+ stop that? [...] It's too late to be thinking about putting arbitrary lines around small bits of degraded forests. Then thinking that's going to stop the tide of oil palm and mining across Kalimantan. The damage has already been done (14 June 2013). 
The abstract line around Sungai Lamandau was drawn because, according to project implementers, the area was under threat of conversion to non-forest uses. Most of the buffer-zone, though officially controlled by BKSDA, remained under a $H P K$ (production/conversion forest) licence and therefore up-for-grabs to anyone willing to purchase the concession and develop it. According to Yayorin programme manager, Wayan: "Applications have been submitted in the past to convert the land to oil palm. They even thought about putting a new airport there once, but that was rejected" (15 July 2013). Yet, according to McCarthy et al. (2012), only a fraction of land developments associated with these transactions are ever implemented, or go on to forcibly exclude anyone. They introduce the term 'virtual land grabbing' to characterise situations where, behind a façade of land acquisition for a stated purpose, there lies an agenda to access subsidies, obtain bank loans using land permits as collateral, or speculate on future increases in land values. In the case of virtual land grabs only a few initial stages of land acquisition or enclosure processes occur; just sufficient to enable specific actors to pursue their own interests.

The actual threat posed to Sungai Lamandau's forests by conflicting land uses was questionable. As Yarrow, a project officer from OFUK explained:

If REDD+ can't do anything it's always been our plan-B to turn the reserve and buffer-zone into a national park, with communities getting some of the benefits from tourism. It's very unlikely now, with such a large population of orangutan and other protected species, that the reserve would be anything other than a conservation area in twenty/thirty-years-time (1 December 2013). 
The implications of this require consideration for the proposed purchasing of Sungai Lamandau's carbon credits. The REDD+ mechanism was designed to 'off-set' genuine emissions created elsewhere with an 'additionality' (or 'saved carbon') produced in Sungai Lamandau. Yet, should the REDD+ project prove successful, the unplanned consequences would equate to a net increase in atmospheric carbon emissions.

The Sungai Lamandau plan was based on inaccurate socio-spatial imaginaries. With restricted local knowledge this inaccuracy presented intrinsic limitations on the capacity of project implementers to improve things. As Li (2007: 17) states, "There are processes and relations that cannot be preconfigured according to plan". In and around Sungai Lamandau's forests, people did not behave the way they were supposed to confined to jurisdictional or racialised spatial boundaries. The women and men enrolled in the REDD+ project were not fixed nor were they attuned to rationally maximise personal gain à la Homo economicus. And this under-explored mobility of people's multi-local lives had significant unexpected consequences.

\subsection{CONCLUSIONS}

Sungai Lamandau's farmers have attempted to bridge the contradiction between needing to demonstrate legitimacy through spatial 'fixity', to access project benefits, and the need to move, to explore opportunities by creating multi-local livelihood strategies. Unlike the cohesive and proximate 'forest dependent communities' pictured by REDD+ project implementers, many Sungai Lamandau farmers instead had adopted multi-local livelihoods. These were spatially extensive forms of livelihood diversification, in which incomes often came from non-local sources. This strategy also contrasted with forms of 
movement or displacement where people migrate and let go of any formal stake in their place of origin, either because there is little prospect for return or they no longer have access to resources there (Elmhirst, 2012).

Multi-localism is a useful tool for exploring the intimacy-geopolitics (Pain \& Staeheli, 2014) of people's engagement in REDD+. The livelihood strategies of Sungai Lamandau's farmers have been understood here as set of spatial relations, coming together through embodied emotions from across Sungai Lamandau and elsewhere. These strategies were produced through a quiet politics - an unassuming praxis of engaging in spaces of REDD+ implementation as well as other more distant localities. New social relations were built in and through these everyday places, relationally connected across a range of geographies (see also Askins, 2014). This intimacygeopolitics approach has privileged the vulnerable bodies of those at the 'sharp end' of REDD+ interventions by disassembling the significance of masculinist geopolitical imaginaries and smudging the arbitrary lines of spatial authority. In doing so the chapter highlights the significance of everyday spatial mobility as an ongoing process of intimacy-geopolitics.

The multi-local livelihoods of Sungai Lamandau's farmers constantly shifted, skipping in and out from the more obvious sites of REDD+ implementation, requiring a suitablyagile lens to bring understanding to them. This chapter has therefore directed attention to the unseen and unexpected, and therefore, to the gaps between the Sungai Lamandau project's design and the experiences of those who were to benefit. These spaces were not so much 'hidden', but were often under-explored. Standardised qualities, based on gender, race and assumed profession, were sometimes more convenient to project 
implementers than the complex geographies where people improvised trajectories towards their own messy dreams.

The REDD+ project focused on the production of agrarian spaces free of market-based risks. However, many people were experiencing a declining dependence on farming. Land was losing its importance as a means of economic reproduction, yet people could not stray far from theirs for long periods. Enhancements in transport links and a loosening of restrictions on mobility (for women in particular) had led to multi-local livelihoods becoming more commonplace and being conducted over considerable distances. The findings from this chapter show that the resilience of women and men across the study site was more a product of these mobility factors and connection to multiple localities, rather than the REDD+ project interventions per se.

The nature of women's agency and geographical mobility in Sungai Lamandau was particularly under-explored by the REDD+ project implementers. While they understood rural areas of Kalimantan as conservative and traditional, the actual social norms and acceptable practices for women had created unseen opportunities. Women's work had become generationally differentiated; income sources had diversified into a range of farm and non-farm activities.

However, as Rigg (2012: 5) warns, one should not be "too much of a romantic not to appreciate that there are limits to agency". 'Power's matrices' (see Li, 2007) to some extent shape what people do and steer people towards or away from whom they want to be. Yet, the analytical frame of multi-localism - woven around conceptions of livelihood performaces, trajectories and diversification - shows that 'structure' is less a means of control than a network of possibility (Elmhirst, 2012). 
REDD+ project planners therefore, need to understand the everyday lives of their intended hosts. People who are ignored will undoubtedly be impacted - maybe positively; maybe negatively, but project implementers are unlikely to ever know which. It is important then that if a commensurable series of carbon projects are 'rolled-out' regionally or even globally, specific histories from one unique space are not stencilled across a different landscape. The important lesson then, concerns the process - how REDD+ project implementers should be looking, rather than what they should see. 


\section{NINE
CHATEROND REDD+}

\section{$9.1 \quad$ INTRODUCTION}

The degradation of Indonesia's forests is an object of global environmental governance (McGregor et al., 2015), constituting the country's largest source of anthropogenic greenhouse gas emissions (Margono et al., 2014). REDD+, as a response, focuses on the provision of economic incentives for forest protection in Indonesia, striving "to make forests more valuable standing than cut down" (Katerere, 2010: 105). Scholars studying REDD + have had difficulty establishing a clear link between theoretical discussions of forest commoditisation and capitalist expansion, with case studies detailing the impacts of these projects in places and on certain populations (Yocum, 2013).

In response this thesis has explored the powers local actors mobilised to access, and exclude others from the diverse and, at times, elusive set of benefits within one 'community-based' REDD+ project in Indonesia. It has explored the many ways in which power was wielded, yielded and negotiated to understand how people actively engage within sites of REDD+ implementation. The case study was the Sungai Lamandau REDD + project in Central Kalimantan, one from a portfolio of four REDD + projects being supported by the Clinton Climate Initiative (CCI) forestry programme (between 2008 and 2013). 
To enable such an exploration, I have drawn on political ecology, adopting a feministinspired intimacy-geopolitics approach (Pain \& Staeheli, 2014) and case-driven ethnographic methods. In doing so, this thesis has challenged the dominant geopolitical narratives of REDD+ in Indonesia. Despite efforts to 'safeguard' people, these narratives have tended to promote global green-growth while disregarding the exclusions and inequalities inherent in such techniques of land appropriation and capital expansion. As of August 2015, there were approximately seventy-five on-going REDD+ projects and 'readiness' activities in Indonesia (GCP, 2015). Each one was experimental in nature and quite dissimilar in approach from any other. However, the lessons learnt from Sungai Lamandau are important for anyone seeking to implement or analyse community-based forest protection in places across Indonesia and beyond.

This chapter concludes my thesis by reviewing these lessons, tying-up the thematic threads which ran through the previous chapters. The following section reflects on what came out of the conceptual framework - the findings born from my analysis of the intimacy-geopolitics of REDD+ in Sungai Lamandau. It then looks back at the many ways in which power was wielded, yielded and negotiated by local actors, sometimes perceiving them as an intimate and everyday counter-movement. I also draw together the discursive 'spectacles' (Debord, 1967) of the REDD+ project that were discussed throughout Chapters five through eight. Before closing the thesis, the penultimate section discusses the important contributions made throughout, reflecting on my initial research objectives, outlined in Chapter one. I also reflect on the limitations of my approach and discuss possible avenues for further scholarly explorations beyond REDD+ in Indonesia. 


\subsection{ANALYSING ACCESS \& EXCLUSION}

\subsubsection{THE GREEN SPECTACLES OF REDD+}

This thesis has described three distinct legitimising 'spectacles' (DeBord, 1967) behind REDD+ implementation in Sungai Lamandau. Firstly, in Chapters five and six, I explained how REDD+ scholarship that adopts a standard geopolitical imaginary, reifies a rigid scalar formation, and homogenises 'the local' as a platform for 'on-the-ground' project implementation. This platforming facilitates a spectacle wherein an equitable and inclusive distribution of benefits is not only possible, but can be rolled out unproblematically across scales of implementation, enabling the fabled win-wins of REDD+ (Jagger et al., 2009).

For Angelsen et al. (2008: 31-32) scales of REDD+ implementation refer to "the accounting levels of an international funding mechanism". Within such an imaginary, various REDD+ benefits can be distributed using a 'subnational approach'. REDD+ activities can be implemented in a defined geographical area with 'communities' incentivised to protect forests through a system of internationally agreed institutional arrangements (ibid). As detailed earlier (see Section 4.3), this scalar imaginary ignores the specificities of sites of exchange, disguises localised motivations and all their complexities - roping the 'poor', the 'local community' together for the sake of equivalence and commensurability.

This thesis has shown in detail how accessing REDD+ benefits in Sungai Lamandau was in fact dependent on complex social relations intersecting through diverse conservation priorities and individual motivations. The feminist-inspired, intimacy-geopolitics imaginary, utilised in this thesis, helped expose the inequity and exclusivity of benefit 
sharing arrangements as the REDD+ project played out in Sungai Lamandau. By dismissing the hierarchy that REDD+ scholars, such as Angelsen et al. (2008) continue to assume is embedded within notions of territory, the thesis shows that scholars can hamper the reification of capitalism's dominance and ultimate authority in REDD+ project implementation and associated scholarship.

The second legitimising spectacle of REDD+, outlined in Chapter seven, relates to the construction of 'forest dependent communities' as illicit 'Others'. Through this spectacle the logic of REDD+ constructs people living in/or around Sungai Lamandau as environmentally destructive - especially men (see Section 7.4.4) - and are therefore in need of incentivisation to do otherwise. The 'opportunity cost' is the bench-mark by which REDD+ incentives are usually formulated (Gregersen et al., 2010). Local people are constructed as needing to degrade forests through small-scale logging (Luttrell et al., 2011); participation in oil palm expansion (ICRAF, 2010); or destructive farming practices (Fox et al., 2011). Yet, in doing so a kind of self-fulfilling prophesy is activated. Ironically, for many of Sungai Lamandau's landless farmers, REDD+ became embroiled in other ongoing processes, pushing farmers towards illicit livelihood strategies, sometimes with destructive outcomes. As discussed earlier (see Section 6.5), those who could have benefited most from the additional support that came with the REDD+ project were often excluded, as more able farmers 'grabbed' the benefits for themselves using them as tools for further accumulation. Perversely however, this destructive behaviour-change worked to legitimise REDD+ interventions, enabling the spectacle that 'local forest dependent communities' required incentives to find sustainable alternatives. 
The third spectacle discussed, which legitimised the REDD+ intervention in Sungai Lamandau, suggests that local communities were spatially fixed and therefore able to consent to the continued enclosure of Sungai Lamandau's forests. This spectacle of 'fixity' - a neat construction of 'forest dependent local communities' living harmoniously close to the forest - allowed for spatial regulation through a framework of safeguards, including 'FPIC' (see Section 5.2.1). Brown et al. (2008: 112) propose two strategies for managing these spatially-fixed communities within a REDD+ framework, including: i) secure property rights for the "forest dependent poor"; or ii) implement "strategies designed to decrease dependence on forests and other natural resources, such as industrial growth". This thesis has shown how the REDD+ project attempted to instantiate both 'the rightness of property' (see Section 6.2.2), and bite-size industries projects of capitalist expansion (see Section 8.4.1).

The findings show that women and men in Sungai Lamandau had already created diverse multi-local livelihood strategies. These livelihoods drew income from a variety of forest, farm and nonfarm sources, spreading risk and building resilience. This strategy contrasts with forms of movement or displacement where people migrate or 'urbanise', and let go of any formal stake in their rural places of origin, either because there is little prospect for return or they no longer have access to resources there. Again, women and men were differentially affected. Families swept up in the propertymaking project saw their young and female members disproportionately disadvantaged by the inevitable process of dispossession, which follows such projects (Springer, 2014). Many people did not require incentivising away from the forests or soils of Sungai Lamandau. Many were already going that way, at least partially. For these people there 
was no 'either-or' problem between 'modern' lives in the city, extractive industries, and agrarian livelihoods; some could have all of these, and more.

By adopting an intimacy-geopolitics lens, this thesis has contributed to advancing understandings of these everyday spatial mobilities in REDD+ settings. These mobilities were social and political processes. In doing so the thesis asserts an imagination of place that is not bounded, but relational. Mobile peoples, networked across messy and protean contexts were the norm, not settled 'forest communities' as others have suggested.

\subsubsection{AN INTIMACY-GEOPOLITICS OF REDD+}

This thesis has helped demonstrate the importance of dissolving the customary boundaries between the global and the local; the familial and state; and the personal and political, within critical investigations of REDD+ (Smith, 2011). Intimacy-geopolitics has been used to effectively articulate the inseparability of politics from economic, environmental and emotional geographies. This framing of intimacy-geopolitics has been understood through three intersecting relations that work simultaneously spatial relations, interactions, and practices (Pain \& Staeheli, 2014).

In doing so, the exploration of Sungai Lamandau has attempted to highlight the utility of an intimacy-geopolitics enquiry for gaining analytical clarity, for thinking through and enacting positive (and perhaps radical) social change. In doing so, it has linked together seemingly disparate people, places, events, and issues to show the connections across various operations of power and productions of inequality. It has demonstrated the ways in which an intimacy-geopolitics challenges the distinct global, national and 
subnational scales of REDD+ negotiations (see Angelsen et al., 2008) and refocuses attention to the seemingly apolitical, 'mundane', everyday reproductions of geopolitical power.

The exploration has highlighted how this intimacy-geopolitics lens can help scholars understand the ways REDD+ manifests in places; to recognise how space and power are differentially experienced and embodied without assisting in the reification of patriarchal social structures. In doing so, intimacy-geopolitics can help shape how REDD+ evolves, pursuing models that are acceptable from social, environmental and economic perspectives. However, engagement with REDD+ in his way does not necessitate acceptance or support of a neo-liberal green-economy. The alternative frame, which this thesis adopts, provides an opportunity to critically contest the basic principles of REDD+, while contributing to a more robust socially and environmentally appropriate future.

By exploring the ways people accessed, and excluded others from, the diverse and elusive set of benefits on offer - this thesis has directed attention to the unplanned, unseen and unexpected, and therefore, to the gaps between the Sungai Lamandau project's design and the experiences of those who were to benefit. The sometimes violent processes of access and exclusion, which occurred within the Sungai Lamandau project, cut across conventional bounds of places and scales and were connected by political relations that traversed realms of intimate and transnational geopolitics. What I have argued here is that an intimacy-geopolitics of access and exclusion can be enriched by taking entwined spatial relations as a starting point and rotating the usual geopolitical lens of analysis. The intimate "is seen to stretch, and reaches around its Others - those who are non-intimates, the public, the global, the geopolitical - and turns 
inside-out" (Pain \& Staeheli, 2014: 345). In adopting this approach the thesis has exposed how a framing of 'benefit sharing', as intimate and geopolitical, works to sustain or transform access controls and powers of exclusion.

These exclusions were sometimes violent and warranted violent counter-exclusions. Within the intimacy-geopolitics frame, violence and displacement have been understood as multi-faceted and multi-sited forces, and are interwoven with other sorts of relations. Violence instituted through the REDD+ project rarely constituted direct physical harm to the bodies of Sungai Lamandau's farmers, even though the threat of such force was almost always at its core. All forms of violent oppression worked through intimate emotional and psychological registers as a means of exerting control (see also Pain, 2014). Through such a framing this thesis has uncovered the nuanced multi-local livelihoods of people as they adapted to violent upheavals, or made REDD+ part of a mix of options which cleared various paths towards more secure futures. The complex livelihood strategies, which this thesis helps make sense of, can be seen as both a cause of, and a reaction to, imposed social and environmental protections - a kind of 'everyday' countermovement.

\subsubsection{THE EVERYDAY COUNTER-MOVEMENT}

In considering the power-relations wrapped up in the REDD+ project, this thesis has attempted to move beyond easily separable dualistic categories, such as state-market, public-private, global-local. I have focussed instead on exploring the 'relationality' of various performances and how the blurring of clear distinctions between positions and spaces was a source of performative instability. Expressions of violence and mobilities 
enabled through processes of access and exclusion were operating as part of a countergeopolitical force - everyday performances enabled transformations in how REDD+ was understood and manifested locally. Due to the complexity of the REDD+ assemblage, viewing these performances through a Polanyian conceptualisation of the doublemovement' proved unsuitable, requiring the use of a more post-structuralist comb to tease out a more nuanced understanding.

Moving beyond Polanyi's various binary oppositions; the thesis exposed the tacit complicity of a purportedly 'green movement' in facilitating market-based expansions into the forest. As I stated earlier in Chapter three, such green actors could once be depended on as critical voices and antagonists with market forces, providing an effective counter-movement to the ravages of capitalist expansion and unbridled economic growth. This thesis shows how such a positioning is difficult to uphold. Orangutan conservation charities, forest protection organisations, and community development bodies, held centre stage in advocating a 'green economy' for Sungai Lamandau's forests. This green economy was firmly located in capitalist networks where economic growth and environmental conservation worked in tandem. Due to the neo-liberalised governance structure, the REDD+ project came with its own regulation and social-protection framework - a neo-liberal counter-movement.

'Social and Environmental Safeguards' offered insufficient protection against the project's own market-based ambitions (see Section 8.4.1). Analysing the strategies of everyday life, which gave shape to the various REDD+ benefits on offer, enable the REDD+ project to be seen as neither a strict neo-liberal 'movement', nor a social protection, or counter-movement, from capitalist expansion into the forest, but something far more complex. Though market-based, the REDD+ project manifested 
through multiple mismatched logics and was understood in many potentially incompatible ways. The four 'powers of exclusion' (markets, regulation, legitimation, and force) analytic helped elucidate how things worked.

All four powers had the potential to both accelerate processes of social differentiation, and also to bring about more desirable outcomes. Being able to control market forces for instance, was of enormous importance in the dynamics of land access for Sungai Lamandau's small-holders. For some, the REDD+ project facilitated a collaborative spirit. Small-holders and rubber tappers who had always worked against each-other in competition, formed cooperatives and unions, which through the REDD+ intervention were able to affect favourable pricing and market access arrangements. However, those excluded from these collective enterprises were pushed further to the social margins. The landless made up the greatest number of casualties. The analysis of market-based access and exclusionary arrangements also shows the gendered dynamics of systematic discrimination that women have experienced within the REDD+ project. Women suffered differential access entitlements to markets, but were also differentially victimised by processes of dispossession (see Section 5.4.1).

Just like market-based access and exclusionary processes, Force radiated from both ends of the double-movement. Force was sometimes exerted viciously through highly coercive powers of debt discipline. However, force worked both ways. It enabled counter-exclusions, reconstructed dominant gendered and racialised hierarchies while enabling those without formal land title to access a means of economic reproduction (see Section 6.4.5).

Regulation was also 'double-edged' sometimes taking the form of forced evictions or 'violent extraction' (see Section 7.4.4). Conversely, powers to regulate allowed some BEYOND REDD+ | 298 
groups to manage land and resources themselves, empowering those previously marginalised (see Section 6.4.3). These marginalised groups often used powers of legitimation through discourses of indigeneity (see Section 6.4.5), spatial proximity, or livelihood connection (see Section 5.4.4). All of these legitimising processes required both a move to secure access to things and/or a counter-movement to prevent exclusion. However, legitimation of the REDD+ project, as part of a wider greeneconomy spectacle, was based on implicit and disingenuous undertakings.

The findings within this thesis have provided numerous theoretical and practiceorientated contributions to knowledge within geography and beyond. The rest of this chapter discusses these contributions, reflecting on my initial research objectives, outlined in Chapter one. I also reflect on the limitations of my approach and discuss possible avenues for scholarly exploration beyond REDD+ in Indonesia.

\subsection{EXPLORING BEYOND REDD+ IN INDONESIA}

\subsubsection{THESIS CONTRIBUTIONS AND LIMITATIONS}

This thesis has drawn from post-structural feminist political ecology to investigate access controls and exclusions from REDD+ benefits. In doing so I have added to the small, but growing, body of political ecology research that explores how REDD+ is manifesting in rural Indonesia. More specifically, the thesis contributes to this political ecology research in three important ways. Firstly, the thesis provides a much greater level of understanding around the complex and messy configurations of actors critically engaging in the REDD+ project in Sungai Lamandau. I have avoided categorising the women and men who took part, and boxing them based upon externally-observable 
variables. Instead I focused on ephemeral performances of class, livelihood, gender, race, ethnicity, indigeneity and forest-dependence. 'Indigeneity' is a hugely complex category in Indonesia, often rendered neat and malleable by REDD+ research that fails to listen to shouts of 'suku asli' (original tribe), 'masyarakat adat' (customary community), 'orang sini' (people of this place) and others (see Section 6.5). This thesis suggests that internationally recognised standards of indigeneity for the sake of commensuarbility offer insufficient analytical traction to elucidate the complex forests of Kalimantan and beyond.

Secondly, the thesis has helped towards an understanding of what did and did not constitute a 'REDD+ benefit' in Sungai Lamandau. Benefit sharing commonly refers to the distribution of both the monetary and the non-monetary benefits generated through the implementation of REDD+ projects (Luttrell et al., 2013). Proposed benefit sharing mechanisms involve a variety of institutional means, governance structures and instruments for distributing finance and other benefits. 'Policies and Measures' (PAMs) divide the compensations for foregone 'opportunity costs' from the incentives to induce positive choices of behaviour. These ideas of 'opportunity costs' and incentivising good behaviour did not fit many people's notions of 'risk' and 'benefits' in Sungai Lamandau. The benefits actors pursued in this case study were diverse, and included things beyond property or financial remuneration which could be predicted with 'rational-choice' models and other tools of economic analysis. The benefits pursued usually concerned power, existing livelihood trajectories and social safety-nets. This thesis has argued that in Sungai Lamandau, risks and benefits are therefore better thought through an accessexclusion analytic, because risks were often hidden and associated with dispossession from land and other resources. That is to say, REDD+ project implementers, and 
scholars alike, must appreciate the messy character of specific places, which can only be understood, as they should, using indepth ethnographic methods. A single analytical master-key for enabling a global understanding of 'forest people' and their potential role in facilitating a green economy is unlikely to be very useful.

Scholarship exploring 'forest people's' access to and exclusions from REDD+ projects raises both specific questions about women's participation, and more general issues concerning assumptions about the 'accessibility' of women, and the representation of women's perceptions (see Section 4.3.2). Ardener (1975) highlights the frequent absence of women's perspectives in research, which continues today in much REDD+ scholarship (see Angelsen et al., 2008). The produced narratives are often a product of only talking to men, and about women. Men are often universally accepted as 'good informants', able to articulate knowledge and explanations of REDD+ models, which meet the expectations of investigators and include representation of women's concerns (see also Mosse, 1994). Women however, are considered difficult to reach. Women "giggle when young, snort when old, reject the question, laugh at the topic, and the like" (Ardener, 1975: 2). Researchers of natural resource management sometimes "have a bias towards the kinds of models that men are ready to provide (or to concur in) rather than towards any that women might provide" (Mosse, 1994: 511-512).

This thesis recognises that masculinist scholarly models of REDD+ are incomplete; they do not, and perhaps cannot, express important aspects of women's experience and interests in places, or what for them constitutes a REDD+ 'risk' or 'benefit'.

Thirdly, this thesis has considered the diverse array of actors' engagements in the REDD+ project without using a crude comparison of 'before and after' or 'here and there'. In doing so the thesis enables a greater understanding of the nuances of REDD+ 
interventions as they occurred within specific locations involving specific populations. The research findings have helped reveal the 'humble and mundane' mechanisms by which implementers have sought to instantiate REDD+ in Sungai Lamandau. This thesis has also provided a timely exploration of the workings of REDD + beyond reductive analysis, which has tended to remain overly focused on links between benefit sharing, safeguards, additionality, measuring and verification. Instead I have attempted to address the need to centre human agency within studies of forest governance. In doing so I have emphasised the hidden nature of the often violent access and exclusionary arrangements instituted through REDD+ discourses.

This thesis offers a temporal and spatial 'snapshot' of ongoing processes and, therefore, is limited in a number of ways. The management of and efforts to protect Sungai Lamandau's forests started a long time ago. The REDD+ project was, as Rigg (2011: 179) describes it, "a subject of contingent development" - previous conservation project failures had led to a success, which led to a failure, before another success. This thesis was not able to view the turbulent path leading toward today's REDD+ project in Sungai Lamandau, nor was it able to guess at the likely developmental outcome of this project in future. Furthermore, it is obvious that REDD+ looks very different in every site of implementation. Sungai Lamandau is just one such site.

But, what my enquiry does offer is depth. Given more time it may have proven useful to explore other sites of implementation with all the detail and scholarly activism they deserve. Time pressures however, as well as funding issues, meant that it was not feasible as part of this doctoral research project. I may endeavour to look at other sites of implementation separately in due course. 
This enquiry has also responded to recent calls to connect critical and practiceorientated research objectives within REDD+ scholarship. As I explained earlier, in Chapter one, political ecology is an approach that holds the potential as both hatchet and seed, offering critique, deconstructing and discarding dominant narratives in search of new alternatives. Therefore, I now want to turn to consider the potential 'seed' sown from my critique of REDD+ - alternatives from which may sprout more equitable outcomes.

\subsubsection{CONSTRUCTING ALTERNATIVES}

As explored earlier in Chapter two, while policymakers worldwide have come to acknowledge the catastrophic consequences of rising atmospheric $\mathrm{CO}_{2}$ concentrations, twenty-five years of international market-based policy actions to reverse this trajectory have continued to fail. In the context of Sungai Lamandau the proposed purchasing of carbon credits - a mechanism to 'off-set' genuine emissions created elsewhere, may equate to a net increase in atmospheric carbon emissions (see Section 8.4.5). As part of a misleading global accounting system, REDD+ offers consumers (if morphed into a wholly voluntary system) or states (as 'points of obligation' in a compliance framework) to defer the impacts of their over-consumption to other populations and spaces. This accounting system currently operates like a confessional for fetishistic disavowal (Žižek, [1989] 2008), allowing consumers' absolution in one place while blaming foreigners in another (Rosling, 2014).

Green-growth, as I have discussed earlier in Chapter two, maintains a feeble hyphen. REDD+, should it end up sitting within a green-economy framework, is likely to be a 
primary engine allowing economic growth (business-as-usual) to continue unabated. Rowan (2014: 1) articulates the obvious point that perpetual green-growth, like any growth, is impossible. The inevitabilities of compound growth mean that if the 2015 predicted global growth rate (3.1 per cent) were sustained, and the consumption of raw materials were miraculously reduced by ninety per cent, "the inevitable" would be delayed by just seventy-five years. Efficiency and carbon trading solve nothing while 'growth' continues.

With this in mind, alternative discourses under the headings of 'buen vivir' (good living) ${ }^{48}$ and 'degrowth' are gaining attention (D'Alisa et al., 2014). These nascent schools of thought and action share the conviction that ecological sustainability and social justice are incompatible with unfettered free-market capitalism and perpetual economic growth - green or otherwise. Both schools present the idea that fossil fuelbased trajectories and limitless economic growth are not only impossible contradictions of capitalism (without immense ecological degradation), but are also undesirable to most people's ideas of living well (Gudynas, 2013).

Alternatives to economic growth and conventional versions of economic development offer a better chance of achieving well-being and fulfilment for the majority (McAfee, 2014). Degrowth, as a political-intellectual project, both influences and is influenced by anti-capitalist or 'post-capitalist' ideas and new social movements that have spread in the wake of the 2008 financial crisis (Gibson-Graham, 2013).

\footnotetext{
${ }^{48}$ In English, buen vivir loosely translates to 'good living' or 'well living', although neither term sits well with the implied meaning. Gudynas states (in Balch 2013:1) that western translations sit too close to Western notions of wellbeing or welfare: "These are not equivalents at all. With buen vivir, the subject of wellbeing is not [about the] individual, but the individual in the social context of their community and in a unique environmental situation."
} 
Like degrowth, buen vivir rejects growth as an objective for development (MartinezAlier et al., 2010). The concept was first articulated by Latin American rural and indigenous social movements and their academic supporters, and is linked to various indigenous (non-Western) ideas rejecting export-driven development in favour of endogenous strategies aimed at eco-social sustainability (Lang et al. 2013). The concept now appears in the constitutions of Ecuador and Bolivia and is frequently invoked by their governments, albeit more in rhetoric than practice (McAfee, 2014; Radcliffe 2012). Although understood more widely across Latin America, buen vivir is described as "a plural endeavour" (Gudynas, 2011:443) - not limited to framings within specific indigenous knowledges. Therefore, in the context of Sungai Lamandau, such models for development and forest protection could prove advantageous for local farmers and the global climate.

It is not my intention here to evaluate Sungai Lamandau through these hypothetical alternatives to a market-based REDD+. The sheer number of 'unknown-unknowns' (as discussed in Chapter eight) would be too great to warrant an exercise of that sort without further research. However, if a forest protection project neither reduces global emissions, nor avoids deforestation or forest degradation, but conjures economic growth, it cannot rightly be called 'REDD+'. It is totally feasible for REDD+ in Sungai Lamandau, and beyond, to follow non-market-based courses. These courses should provide solutions to the insatiability of corporate-consumer interests in the products of Kalimantan's forests, rather than solving the 'green spectacles' of violent communities in need of corporate benevolence. Allowing markets, financialised transactions, or economic logic to decide these courses merely provides cover for certain interests to consolidate their control over resources and accumulate the benefits derived from 
conservation activities (Matulis, 2015). Instead, appropriate interventions in the lives of marginalised people should be modest and relieved of grandiose masculine objectives of control.

Prevailing rhetoric holds that 'there is no alternative' to the economic valuation of nature (Žižek, 2011). Yet, alternatives do exist, including: buen vivir, degrowth, food and forest re-commoning (see Vivero Pol, 2015), ethics-based management (see Azqueta \& Delacamara, 2006), and a not-for-profit or 'social economy' (see Connelly et al., 2011). These alternatives need to be treated with the same serious consideration as economic valuation. Acceptance of a market-based REDD+ in light of so many clearly identified drawbacks, from this thesis and elsewhere, is irresponsible (see also McAfee, 2014; Cavanagh \& Benjaminsen, 2014; Matulis, 2014; Nel; 2015). Whatever alternative framework emerges, conservation must be undertaken to provide the broadest social and ecological well-being, and not for the primary objective of generating valuable environmental services (Matulis, 2014). There is a clear need to investigate these alternatives through empirically based projects of scholar activism. Examples need to be found where desirable outcomes can be used as potential models, without universal stencilling.

\subsubsection{WHERE TO FROM HERE?}

The lessons from Sungai Lamandau show that incentives for participating in REDD+ should consist of viable livelihood options, which reflect the aspirations of those people within spaces of implementation. As it was, the regulation of allowable 'sustainable alternative livelihoods', based upon Non Timber Forest Products (NTFPs) was 
ineffective. These alternatives, which included native jelutung rubber tapping, rattan and home industries, constituted what for many people were hobbies, or hangovers from agrarian pasts, not a practicable means towards realising their dreams of better things (see also Dove, 2011). Access to existing NTFPs, such as jelutung rubber was highly exclusive. The formalisation of access requirements associated with the Sungai Lamandau conservation activities removed what for many constituted their economic safety net. As explained in Chapter six, Sungai Lamandau's farmers were being obstructed from their survival strategies and tools handed down through generations. This had the effect of pushing already struggling people further towards economic insecurity. One has to question why these options were considered a 'sustainable alternative livelihood', when for the vast majority of farmers, their existing livelihood strategies could not easily be considered 'unsustainable' or destructive.

It is still widely assumed that the growing popularity of offsetting among governments, industry and civil society, means commoditised carbon projects, like that proposed for Sungai Lamandau, are probably here to stay (Lovell et al., 2009; Corbera \& Brown, 2010). The UN Green Economy Initiative is expanding and, like REDD+, will feature prominently at future international climate negotiations (UNFCCC, 2015). These green economy initiatives aim to lift international climate policy above politics to a politically neutral realm where economic reasoning and ecological science predominate (Swyngedouw, 2011). Because carbon trading does not directly challenge existing patterns of consumption or the distribution of wealth and power, major lifestyle sacrifices or confrontation with powerful vested interests are avoided. Daunting political choices can be set aside in favour of measures to bring 'natural capital' into the global marketplace. 
However, these measures make little economic sense. In 2014 GoI spent 126 times more in subsidies to industries that cause deforestation than the country received from the United Nations' REDD+ scheme (ODI, 2015) ${ }^{49}$. This spending constituted subsidies to the oil palm, timber, soy, beef and biofuels sectors between 2009 and 2012. Rehman (in Neslen, 2015a:1) compares GoI to a "cancer charity asking for donations whilst subsidising cigarette production at the same time." He continues:

Deforestation is ultimately driven by consumption demands in the North. [...] We all have a responsibility to tackle the businesses that are colluding in this destruction. The only real solution to this failure is empowering communities to safeguard their forests.

These 'communities' however, must be considered within a context of globalisation. For the most part, the farmers of Sungai Lamandau did not conduct their lives according to jurisdictional boundaries. Furthermore, there is compelling evidence across Indonesia that multi-local livelihoods are of growing significance for rural people seeking to diversify agrarian sources of income (Rigg 2006; Elmhirst, 2011b; 2012). As rural livelihoods become increasingly multi-local, and sometimes transnational, considerable challenges are posed for the ways in which REDD+ is envisioned. Migration and mobility are at odds with the spatial dynamic normally associated with natural resource management interventions (Elmhirst, 2012). As discussed in Chapter eight, such interventions attach resource management institutions to geographical territories and thus implicitly carry assumptions about the geographical boundedness of communities and their relationship to particular spaces.

${ }^{49}$ GoI received US \$346m in REDD+ payments between 2009 and 2012, mostly from the Governments of Norway and Germany (Nelsen, 2015a). The Government of Norway has since committed a further US $\$ 1$ billion to finance REDD+ readiness in Indonesia. 
With all this in mind, a tolerable result will of course be messy. But, to ignore the messiness, in favour of chasing an orderly and commensurable REDD+, would be counter-productive at best, as the findings from this thesis have shown.

Žižek (2011) epitomises disavowel of such complexities within a simple anecdote: A drunkard walking back from the pub loses his house keys. He is approached by a policeman who observes him searching under a street light. The policeman asks, 'Can I help you sir?' The drunkard replies, 'Yes, you can search in that dark alley, that's where I lost my keys. I will continue to look under this street light where it's easier to see'.

\section{$9.4 \quad$ CONCLUSIONS}

When Sandor was first presented with the issue of climate change governance in the United States, he explained precisely how the Chicago Stock Exchange was the solution required, before anyone had told him what the problem was (Sandor, 2012). Lash (in Goodell, 2006:1) explains that, "no one has done more than Richard Sandor to get a carbon market up and running". Twenty-three years after Sandor's first environmental derivatives market went online, it has been estimated that the Kyoto protocol's carbon credit schemes have increased global emissions by approximately 600million tonnes (Schneider \& Kollmuss, 2015). According to Kollmuss (in Neslen, 2015b: 1), the implications for emissions trading systems are profound: "The poor overall quality of [carbon off-setting] projects may have undermined the European Union's emission reduction target by some 400 million tonnes of $\mathrm{CO}_{2}-$ about a third of the reductions required by the EU [emissions trading scheme] from 2013 to 2020". 
In 2014 , the carbon market price for off-setting a lifetime of pollution was less than the cost of a tank of petrol. It was possible to offset 581 tons of emissions, about as much as the average European generates in eighty years, for US\$30 (Morales \& Vitelli, 2013). Yet, despite the market failure to enable emissions reductions it is widely believed that the carbon trading mechanisms within the Kyoto Protocol will continue until at least 2020 (Neslen, 2015b). As I explained in Chapter two, Sandor himself has stated that carbon markets have failed, primarily due to inadequate oversight (Sandor, 2012).

This chapter has suggested some alternative courses as well as worthy themes for further research. These suggestions are not motivated through my opposition to the economic valuation of nature due to 'nature's' intrinsic, aesthetic, or cultural value (Matulis, 2014). My resistance stems, rather, from the belief that economic valuation does more to promote uneven accumulation of wealth and extend the reach of global capitalism than it does to expand sound ecological management (see also Brockington \& Duffy, 2010).

Access and exclusionary processes are not inevitable facets of land and resource management in Indonesia. However, as the findings in this thesis show, adversarial relationships are encouraged through a market based REDD+ which relies on welldefined property rights (Farley \& Costanza, 2010). Even in cases where land tenure is secure and risk of dispossession is minimal; such market-based undertakings present a tendency toward exclusionary management practices (Sullivan, 2009). More equitable solutions, which support marginalised people, will undoubtedly require collaboration and re-commoning of resources. 
Until then, REDD+ and carbon-forestry projects like it will not only continue to fail in addressing the root-causes of anthropogenic $\mathrm{CO}_{2}$ emissions, but will continue to be highly exclusive - disproportionately impacting women and those already marginalised. 



\section{REFERENCES}

Adams, W. M. (2004) Against Extinction: The story of conservation. London: Earthscan

Adamson, C. (2007) Gendered Anxieties: Islam, women's rights, and moral hierarchy in Java. Anthropological Quarterly, 80 (1): 5-38

Adas, M. (1986) From Footdragging to Flight: The evasive history of peasant avoidance protest in South and South-east Asia. Journal of Peasant Studies, 13 (2): 64-86

Agarwal, B. (2003) Gender and Land Rights Revisited: Exploring New Prospects via the State, Family and Market. Journal of Agrarian Change, 3 (1-2): 184-224

Agnew, J. (2003) Geopolitics: re-visioning world politics. Routledge: New York

Agrawal, A. (2001) Common Property Institutions and Sustainable Governance of Resources, World Development, 29 (10): 1649-1672

Agrarwal, A. \& Redford, K. (2009) Conservation and Displacement: An Overview. Conservation and Society, 7 (1): 1-10

Agrawal, A. \& Gibson, C. (1999) Enchantment and Disenchantment: The role of community in natural resource conservation, World Development 27 (4): 629-649.

Agrawal, A. \& Gibson, C. (eds.) (2001) Communities and the Environment: Ethnicity, gender, and the state in community-based conservation. Piscataway, New Jersey: Rutgers University Press

Agrawal, A. (2005) Environmentality. Current Anthropology, 46 (2): 161-190.

Allen, J. (1999) Spatial Assemblages of Power: From domination to empowerment, in D. Massey, J. Allen \& P. Sarre. Human Geography Today, 194-218. Cambridge: Polity Press.

Allen, J. (2004) Whereabouts of power: Politics, government and space. Geografiska Annaler Series B, Human Geography, 86 (1): 19-32 
Angelsen, A., Brockhaus, M., Kanninen, M., Sills, E., Sunderlin, W. D. \& WertzKanounnikoff, S. (Eds) (2009) Realising REDD+: National strategy and policy options. CIFOR, Bogor, Indonesia

Angelsen, A., \& McNeill, D. (2012) The Evolution of REDD+. In A. Arild, B. Maria, D. S. William, \& V. V. Louis (Eds.), Analysing REDD+ challenges and choices (31-49). Bogor, Indonesia: CIFOR.

Angelsen, A., Streck, C., Peskett, L., Brown, J. \& Luttrell, C. (2008) What is the Right Scale for REDD? The implications of national, subnational and nested approaches. CIFOR InfoBrief No. 15. CIFOR, Bogor, Indonesia

Appadurai, A. (1986) Introduction: commodities and the politics of value. In Appadurai, A. (Ed.), The Social Life of Things: Com- modities in Cultural Perspective. Cambridge University Press, Cambridge, 3-63

Araghi, F. A. (1995) Global Depeasantization, 1945-1990, The Sociological Quarterly, 36 (2): $337-68$

Ardener, S. (1975) Perceiving Women. John Wiley: London

Arendt, H. (1963) Eichmann in Jerusalem: A Report on the Banality of Evil. Viking: New York

Arendt, H. (1966) The Origins of Totalitarianism. New York: Harcort, Inc

Arhin, A. A. (2014) Safeguards and Dangerguards: A Framework for Unpacking the Black Box of Safeguards for REDD+. Forest Policy and Economics, 45, 24-31.

Askins, K. (2014) A Quiet Politics of Being Together: Miriam and Rose. Area 46, (4): 344360

Astuti, R. Y. \& McGregor, A. (2015) REDD+ Governmentality in Indonesia: Governing forest carbon through the REDD+ Task Force. Asia Pacific Viewpoint. Forthcoming.

Autonomous Geographies Collective (ACG) (2010) Beyond Scholar Activism: Making strategic interventions inside and outside the neoliberal university. Acme, 9(2): 245275 
Azqueta, D. \& Delacamara, G., (2006) Ethics, Economics and Environmental Management. Ecological Economics, 56, 524-533

Badan Pusat Statistik (BPS) (2011) Kalimantan Tengah Dalam Angka, 2011, https://oegy.files.wordpress.com/2012/10/kalimantan-tengah-dalam-angka-2011.pdf, Accessed Online (15 August 2013)

Badan Pusat Statistik (2012) Berita Resmi Statistik: Palangkaraya, KalTeng. Accessed online (29 December 2013). http://kalteng.bps.go.id/.

Badiou, A. (2012) The Rebirth of History: Times of Riots and Uprisings. Verso: London

Baird, I. G. (2014) Political memories of conflict, economic land concessions, and political landscapes in the Lao People's Democratic Republic. Geoforum, 52, 61-69

Baird, T. D., \& Leslie, P. W. (2013) Conservation as disturbance: Upheaval and livelihood diversification near Tarangire National Park, northern Tanzania. Global Environmental Change, 23(5): 1131-1141

Bakker, K. (2010) The limits of neoliberal natures: Debating green neoliberalism, Progress in Human Geography, 34(6): 715-735.

Barker, D. (2005) Beyond women and economics: Rereading women's work, The University of Chicago Press, 39(3): 258-275

Barnes, T. J., \& Duncan, J. S. (1992) Introduction: writing worlds. In T. J. Barnes \& J. S. Duncan (Eds.), Writing Worlds: Discourse, Text and Metaphor in the Representation of Landscape (1-17). London; New York: Routledge.

Bauman, Z. (2011) Interview - Zygmunt Bauman on the UK riots. Accessed Online (7 March 2014). http://www.social-europe.eu/2011/08/interview-zygmunt-bauman-onthe-uk-riots

Bebbington, A. (1999) Capitals and Capabilities. A Framework for Analysing Peasant Viability, Rural livelihoods and Poverty in the Andes. A Background Paper. IIED/DfID

Becker, L C. (2001) Seeing green in Mali's woods: colonial legacy, forest use, and local control. Annals of the Association ofAmerican Geographers, 91 (3): 504-526. 
Belcher, B. (2012) Forests, poverty and conservation: An overview of the issues. In Biodiversity Conservation and Poverty Alleviation: Exploring the Evidence for a Link (eds D. Roe, J. Elliott, C. Sandbrook and M. Walpole), John Wiley \& Sons, Ltd, Chichester, UK

Bell, L. A. (1993) Rethinking ethics in the midst of violence: A feminist approach to freedom. Rowman \& Littlefield: Maryland

Benjamin, W. (1921 [1996]). Walter Benjamin: Selected writings, Vol. 1, 1913-1926, ed. M. Bullock and M. W. Jennings. Cambridge, MA: Belknap Press, Harvard University Press Benjaminsen, T. A. (2002) Formalising land tenure in rural Africa. Forum for Development Studies, 29 (2): 362-366

Berger, M. (1989) Giving Women Credit: The strengths and limitations of credit as a tool for alleviating poverty. World Development, 17(7):1017-1032.

Berkes, F. (2012) Poverty Reduction Isn't Just about Money: Community Perceptions of Conservation Benefits, in Biodiversity Conservation and Poverty Alleviation: Exploring the Evidence for a Link (eds D. Roe, J. Elliott, C. Sandbrook and M. Walpole), John Wiley \& Sons, Ltd, Chichester, UK.

Bernard, F., Minang, P. A., Adkins, B., \& Freund, J. T. (2014) REDD+ projects and national-level Readiness processes: a case study from Kenya. Climate Policy, 14, 6, 788800

Beymer-Farris, B. A., \& Bassett, T. J. (2012) The REDD Menace: Resurgent protectionism in Tanzania's mangrove forests. Global Environmental Change, 22(2): 332-41

Bhabha, H. K. (1994) The Location of Culture. Routledge: London

Black, R. \& Watson, E. (2006) Local community, legitimacy, and cultural authenticity in postconflict natural resources management: Ethiopia and Mozambique. Environment and Planning D, 24, 263-282

Blaikie, P. (1985) The Political Economy of Soil Erosion in Developing Countries. London: Longman. 
Blaikie, P. (2006) Is small really beautiful? Community-based natural resource management in Malawi and Botswana. World Development, 34, 1942-1957

Blaikie, P. (2012) Should some political ecology be useful? The Inaugural Lecture for the Cultural and Political Ecology Specialty Group, Annual Meeting of the Association of American Geographers, April 2010, Geoforum, Journal of Physical, Human, and Regional Geosciences, 43(2): 231-239

Blom, B., Sunderland, T., \& Murdiyarso, D. (2010) Getting REDD to work locally: lessons learned from integrated conservation and development projects. Environmental Science and Policy, 1-9

Blomley, N. (2003) Law, property, and the Geography of violence: the frontier, the survey, and the grid. Annals of the Association of American Geographers, 93(1): 121-41

Bock, S. (2014) Politicized expertise - an analysis of the political dimensions of consultants' policy recommendations to developing countries with a case study of McKinsey's advice on REDD+ policies. Innovation: The European Journal of Social Science Research, 27 (4): 379-97

Boellstorff, T. (2005) The Gay Archipelago: Sexuality and Nation in Indonesia. Princeton University Press, Princeton, NJ

Bond, I., Grieg-Gran, M., Wertz-Kanounnikoff, S., Hazlewood, P., Wunder, S., and Angelsen, A. (2009) Incentives to sustain forest ecosystem services: A review and lessons for REDD'. UK.: International Institute of Environment and Development.

Bondi, L. (2009) Teaching reflexivity: undoing or reinscribing habits of gender? Journal of Geography in Higher Education, 33(3): 327-37.

Börner J., \& Wunder, S. (2008) Paying for avoided deforestation in the Brazilian Amazon: From cost assessment to scheme design. International Forestry Review, 10 (3): 496-511

Borras, S. M., Hall, R., Scoones, I., White, B. \& Wolford, W. (2011) Towards a better understanding of global land grabbing: an editorial introduction. Journal of Peasant Studies, 38 (2): 209-16 
Bourdieu, P. (2001) Masculine Domination. Stanford: Stanford University Press

Bowen, J. (1986) On the Political Construction of Tradition: Gotong Royong in Indonesia. Journal of Asian Studies, 45(3): 545-61

Boyd, E. (2009) Governing the Clean Development Mechanism: Global rhetoric verses local realities in carbon sequestration projects. Environment and Planning A, 41, 23802395

Bradshaw, M., \& Stratford, E. (2010) Qualitative research design and rigour. In I. Hay (Ed.), Qualitative Research Methods in Human Geography (3rd Ed., 69-80). Melbourne: Oxford University Press

Brandon, P. \& Hogan, D. (2008) New approaches to household diversity and change. Journal of Population Research, 25, 247-250

Braun, B., \& Wainwright, J. (2001) Nature, poststructuralism, and politics. In N. Castree \& B. Braun (Eds.), Social Nature: Theory, Practice, and Politics (41-63). Malden, MA: Blackwell

Brenner, S. (1998) The Domestication of Desire: Women, Wealth and Modernity in Java. Princeton University Press, Princeton

Bridge, G. (2001) Resource triumphalism: Postindustrial narratives of primary commodity production. Environment and Planning A, 33, 2149-73

Bridge, G. (2009) Material Worlds: Natural Resources, Resource Geography and the Material Economy. Geography Compass, 3 (3): 1217-1244

Brockhaus, M. (2014) Strong commitments, then silence from key player in REDD+ policy arena, CIFOR Forest News, http://blog.cifor.org/25692/strong-commitmentsthen-silence-from-key-player-in-redd-policy-arena\#.VePhLfaqqkp, Accessed Online (31 January, 2014)

Brockington, D. \& Duffy R. (2010) Capitalism and Conservation. Antipode, 42(3)

Brockington, D. (2002) Fortress Conservation: The Preservation of the Mkomazi Game Reserve, Tanzania. Oxford: James Currey 
Brockington, D. (2011) Ecosystem Services and Fictitious Commodities. Environmental Conservation 38 (4): $367-9$

Brockington, D., Duffy, R. \& Igoe, J. (2008) Nature Unbound: Conservation, Capitalism and the Future of Protected Areas. Earthscan Publications Ltd., London

Brockington, D., Igoe J. \& Schmidt-Soltau, K. (2006) Conservation, human rights, and poverty reduction. Conservation Biology 20(1): 250-252

Brosius, J.P., Tsing, A.L. \& Zerner, C. (1998) Representing Communities: Histories and Politics of Community- Based Natural Resource Management, Society and Natural Resources 11, 157-68

Brown, D., Frances, S., \& Peskett, L. (2008) How do we Achieve REDD Co-Benefits and Avoid Doing Harm? In Moving Ahead with REDD: Issues, Options and Implications, edited by Arild Angelsen, 107-118. Bogor, Indonesia: CIFOR

Bullock, S. \& Lawson, S. (2008) Managing the 'commons' on cadillac mountain: a stated choice analysis of Acadia National Park visitors' preferences. Leisure Sciences, 30, 7186.

Bumpus, A. \& Liverman, D. (2008) Accumulation by Decarbonisation and the Governance of Carbon Offsets. Economic Geography, 84 (2): 127-56

Burawoy, M. (2003) For a sociological Marxism: the complementary convergence of Antonio Gramsci and Karl Polanyi. Politics and Society, 31, 193-226

Busse, M. \& Strang, V. (2011) Introduction: Ownership and appro- priation. In Busse, M., and Strang, V. (eds.), Ownership and Appropriation. Berg, Oxford, 1-20.

Butler, J. (1990) Gender Trouble: Feminism and the Subversion of Identity. New York: Routledge

Butler, J. (1993) Bodies that Matter: On the Discursive Limits of Sex. London: Routledge Butler, J. (1997) Excitable speech: a politics of the performative Routledge, New York Butler, J. (2004) Undoing Gender, London: Routledge 
Butler, J. (2012) Partingways: Jewishness and the critique of Zionism Columbia University Press, New York

Butler, J. \& Athanaisiou, A. (2013) Dispossession: The Performative in the Political, Polity: London

Cahill, C., Sultana, F., \& Pain, R. (2007) Participatory ethics: politics, practices, institutions. ACME, 6(3), 304-318.

Callon, M. (1998) The laws of markets, Blackwell, Oxford.

Canon, W. B. (1923) Traumatic Shock. 1871-1945 Stanton A. Friedberg, M.D. Rare Book Collection of Rush University Medical Center at the University of Chicago. ICU

Caouette, D. \& Turner, S. (eds) (2009) Agrarian Angst and Rural Resistance in Contemporary Southeast Asia. Routledge, London

Carbon Finance (2010) Calls grow for better regulation of EU carbon market. In Whitington, J. (2012) The prey of uncertainty: Climate change as opportunity. Ephemera, 12 (1/2): 113-137

Carino, J., \& Colchester, M. (2010) From Dams to Development Justice: Progress with 'Free Prior and Informed Consent' Since the World Commission on Dams Water Alternatives, 3. 423-437

Castree, N. (2008) Neoliberalising nature: processes, effects, and evaluations. Environment and Planning A, 40(1), 153-173.

Cavanagh, C., \& Benjaminsen, T. (2014) Virtual nature, violent accumulation: The "spectacular failure" of carbon offsetting at a Ugandan National Park. Geoforum, 56 (1): $55-65$

Charles, N. \& Kerr, M. (1988) Women, food and families. Manchester: Manchester University Press

Charmaz, K. (2011) Grounded theory methods in social justice research. In N. K. Denzin \& Y. S. Lincoln (Eds.), The SAGE Handbook of Qualitative Research (4th ed., pp. 359380). Thousand Oaks: SAGE. 
Chatterton, P., Fuller, D. \& Routledge, P. (2008) Relating action to activism: Theoretical and methodological reflections. In Participatory action research approaches and methods: Connecting people, participation and place, ed. S. Kindron, R. Pain, and M. Kesby, 216-22. London and New York: Routledge.

Chiu, L.F. (2006) Critical reflection: More than nuts and bolts. Action Research, 4(2), 183-203

Christie, M. E. (2006) Kitchenspace: Gendered territory in central Mexico. Gender, Place and Culture 13, no. 6: 653-61.

CIFOR (2000) Commercialisation of Non-Timber Forest Products: Review and Analysis of Research, CIFOR: Bogor

CIFOR (2013) Indonesia's Forest Moratorium: Analyzing the numbers, http://blog.cifor.org/3272/indonesias-forest-moratorium-analyzing-thenumbers\#.VeTRCPaqqko, Accessed Online (14 January, 2015)

Clark, N. (2003) Feral ecologies: Performing life on the colonial periphery. In B. Szersynski, W. Heim and C. Waterton (eds) Nature Performed: Environment, Culture and Performance, Oxford: Blackwell, 163- 182

Client Earth (2013) A guide to understanding and implementing UNFCCC REDD+ safeguards. Client Earth: London

CMIA (Climate Markets and Investors Association) (2013) A declaration for a balanced approach to financing and implementing REDD+. http://www.ieta.org/assets/PositionPapers/redd\%20declaration\%

20final\%20email.pdf. Accessed Online (11 June, 2014)

Coase, R. H. (1960) The problem of social cost. Journal of Law and Economics,3, 1-44

Collins, P. H. (2000) Black Feminist Thought: Knowledge, Consciousness, and the Politics of Empowerment. 10th ed. London: Routledge

Connell, R. (1987) Gender and Power: Society, the Person and Sexual Politics. Stanford University Press 
Connelly, S., Markey, S., \& Roseland,M. (2011) Bridging sustainability andthesocial economy: achieving community transformation through local food initiatives. Crit. Soc. Pol. 31, 308-324.

Corbera, E. (2014) Valuing nature, paying for ecosystem services and realizing social justice : A response to Matulis ( 2014 ). Ecological Economics, 10-13.

Corbera, E. \& Friedli, C. (2012) Planting trees through the Clean Development Mechanism: a critical assessment. Ephemera, 12:194-229

Corbera, E., \& K. Brown (2010) Offsetting benefits? Analyzing access to forest carbon. Environment and Planning A, 42(7):1739-1761.

Corbera, E., \& Schroeder, H. (2011) Governing and implementing REDD+. Environmental Science \& Policy, 14(2), 89-99

Corbera, E., Brown, K. \& Adger, W. N. (2007) The equity and legitimacy of markets for ecosystem services. Development Change, 38:587-613

Corbera, E., Estrada, M., \& Brown, K. (2010) Reducing greenhouse gas emissions from deforestation and forest degradation in developing countries: revisiting the assumptions. Climatic Change 100, 355-388

Cornwall, A. (2007) Revisiting the "gender agenda". IDS Bulletin 38 (2), 69-78

Corson, C. \& MacDonald, K. I. (2012) Enclosing the global commons: the Convention on Biological Diversity and green grabbing. Journal of Peasant Studies 39: 263-283

Corson, C. (2010) Shifting environmental governance in a neoliberal world: USAID for conservation, Antipode 42 576-602

Costenbader, J. (2010) REDD+ Benefit Sharing: A Comparative Assessment of Three National Policy Approaches. Gland: International Union for Conservation of Nature

Cotula, L. \& Vermeulen, S. (2009) 'Land Grabs' in Africa: Can the Deals Work for Development? London: IIED

Cotula, L., \& Mayers, J. (2009) Tenure in REDD: Start-point or afterthought? IIED Report. (London: IIED) 
Cronin, T. M. (2010) Paleoclimates: Understanding climates past and present. Columbia University Press

Cupples, J. \& Kindon, S. (2014) Returning to university and writing the field. In R. Scheyvans (Ed.), Development Fieldwork: A Practical Guide, 2nd Edition (pp. 236-252). London, U.K.: Sage.

D’Alisa, G., Demaria, F., \& Kallis, G. (eds.) (2014) Degrowth: a vocabulary for a new era. New York, NY: Routledge.

Dalby, S. (2010) Recontextualising violence, power and nature: The next twenty years of critical geopolitics? Political Geography, 29(5): 280-288

Dalby, S. (2008) Warrior geopolitics: Gladiator, Black Hawk Down and The Kingdom Of Heaven. Political Geography, 27 (4):439-455

Dale, G. (2010) Karl Polanyi: The Limits of the Market, Polity Press: Cambridge

Dauvergne, P., \& Neville, K. J. (2010). Forests, food, and fuel in the tropics: the uneven social and ecological consequences of the emerging political economy of biofuels. The Journal of Peasant Studies, 37(4): 631-60

Davies, G., \& Dwyer, C. (2007) Qualitative methods: are you enchanted or are you alienated? Progress in Human Geography, 31(2): 257-266.

Davis, M. (2006) Planet of slums. London: Verso

Davoudi, S. \& Healy, P. (1995) City challenge: sustainable process or temporary gesture? Environment and Planning C: Government and Policy 13, 79-95

De Angelis, M. (2001) Marx and primitive accumulation: The continuous character of capital's enclosures. The Commoner 2:1-22

De Beer, J. H. \& McDermott, M. (1989) The economic value of non-timber forest products in Southeast Asian with emphasis on Indonesia, Malaysia and Thailand. Manuscript by Netherlands Committee for IUCN, Amsterdam 
De Goede, M. (2005) Resocialising and repoliticising financial markets: contours of social studies of finance. Economic sociology: European electronic newsletter, 6, 3, 1928

De Haan, L. \& Zoomers, A. (2005) Exploring the frontiers of livelihood research. Development and Change 36 27-47

De Janvry, A., G. Gordillo, J.P. Platteau, \& E. Sadoulet (2001) Access to Land, Rural Poverty, and Public Action. Oxford: Oxford University Press

Debord, G. (1967 [2014]) The Society of the Spectacle. Bureau of Public Secrets: Berkely Delay, T. (2004) Excess: The Obscene Supplement in Slavoj Žižek's Religion and Politics. International Journal of Zizek Studies, 8, (2): 1-20

Demeritt, D. (2001) Scientific forest conservation and the statistical picturing of nature's limits in the progressive-era United States. Environment and Planning D, 19, 431-59

Den Besten, J. W., Arts, B., \& Verkooijen, P. (2014) The evolution of REDD+: An analysis of discursive-institutional dynamics. Environmental Science \& Policy, 35, 40-48.

Deninger, K., Byerlee, D., Lindsay, J., Norton, A., Selod, H. \& Stickler, M. (2011) Rising global interest in farmland: Can it yield sustainable and equitable benefits? The World Bank, Washington DC

Denman, K. L., G. Brasseur, A. Chidthaisong, P. Ciais, P. M. Cox, R. E. Dickinson, D. Hauglustaine, C. Heinze, E. Holland, D. Jacob, U. Lohmann, S. Ramachandran, P. L. da Silva Dias, S. C. Wofsy, and X. Zhang. (2007) Couplings between changes in the climate system and biogeochemistry. Pages 499-588 in S. Solomon, D. Qin, M. Manning, Z. Chen, M. Marquis, K. B. Averyt, M. Tignor, and H. L. Miller, editors. Climate change 2007: the physical science basis. Contribution of Working Group I to the Fourth Assessment Report of the Intergovernmental Panel on Climate Change. Cambridge University Press, Cambridge, UK

Derickson, K. D. \& Routledge, P. (2014) Resourcing Scholar-Activism: Collaboration, Transformation, and the Production of Knowledge. The Professional Geographer, (March 2015), 1-7 
Derrida, J. (1967) Grammatology. Les Éditions de Minuit

Derrida, J. (1967) L'Ectriture et la difference, Paris: Seuil.

Derrida, J. (1972) Dissemination. Bloomsbury: London

DeVault, M. (1991) Feeding the family: The social organisation of caring as gendered work. Chicago, IL: University of Chicago Press

Di Gregorio, M., Brockhaus, M. Cronin, T., Muharrom, E., Santoso, L., Mardiah, S., \& Büdenbender, M. (2013) Equity and REDD+ in the media: a comparative analysis of policy discourses. Ecology and Society. 18(2): 39

Dixon, R. \& Challies, E. (2015), Making REDD+ pay: Shifting rationales and tactics of private finance and the governance of avoided deforestation in Indonesia. Asia Pacific Viewpoint, 56: 6-20

Djajadiningrat-Nieuwenhuis, M. (1987) Ibuism and priyayization: path to power? In: Locher-Scholten, E., Niehof, A. (Eds.), Indonesian Women in Focus: Past and Present Notions. Foris Publications, Dordrecht, 43-51

Dormady, N.C. (2013) Market power in cap-and-trade auctions: A Monte Carlo approach. Energy Policy 62:788-797.

Douzinas, C. (2013) Philosophy and Resistance in the Crisis: Greece and the Future of Europe. Polity: London

Dove, M. R. (1993) A revisionist view of tropical deforestation and development. Environmental Conservation 20: 17-24

Dove, M. R. (2011) The Banana Tree at the Gate: A History of Marginal Peoples and Global Markets in Borneo. Yale University Press

Dowler, L., Christian, J. \& Ranjbar, A. (2014) A feminist visualisation of the intimate spaces of security. Area, 46 (4): 344-360

Dowler, L. \& Sharp, J. (2001) A feminist geopolitics? Space \& Polity, 5, 165-176 
DtE, (2001) Dibalik Kerusuhan di Kalimantan Tengah. Accessed 10 May 2014 from: http://www.downtoearth-indonesia.org/id/story/dibalik-kerusuhan-di-kalimantantengah

Eilenberg, M. (2015) Shades of Green and REDD: Local and global contestations over the value of forest versus plantation development on the Indonesian forest frontier. Asia Pacific Viewpoint, 56(1): 48-61

Eliasch, J. (2008) Climate change: Financing global forests: The Eliasch review. London: Earthscan.

Elmhirst, R. (2011a) Introducing new feminist political ecologies. Geoforum, 42, (1):129-32

Elmhirst, R. (2011b) Migrant pathways to resource access in Lampung's political forest: Gender, citizenship and creative conjugality. Geoforum, 42, (1): 173-83

Elmhirst, R (2012) Displacement, Resettlement and Multi-local Livelihoods: Positioning Migrant Legitimacy in Lampung, Indonesia. Critical Asian Studies, 44, (1): 131-52

Elmhirst, R. \& Resurreccion, B.P. (2008) Gender, environment and natural resource management: new dimensions, new debates. In: Resurreccion, B.P., Elmhirst, R. (Eds.), Gender and Natural Resource Management: Livelihoods, Mobility and Interventions. Earthscan, IDRC ISEAS Publications, London, Singapore, 3-22

Engel, S., and C. Palmer. (2008) Painting the forest REDD? Prospects for mitigating climate change through Reducing Emissions from Deforestation and Degradation. IED Working Paper 03, Institute for Environmental Decisions, Swiss Federal Institute of Technology, Zurich, Switzerland

Engel, S., Pagiola, S., \& Wunder, S. (2008) Designing payments for environmental services in theory and practice: an overview of the issues. Ecological Economics 65, $663-674$

Engels, A. (2006) Market creation and transnational rule-making: The case of CO2 emissions trading, in M.L. Djelic (ed.) Transnational governance: Institutional dynamics of regulation. Cambridge University Press 
England, K. (1994) Getting personal: reflexivity, positionality, and feminist research. Professional Geographer, 46, 1, 80-89

Evans, P. (2008) Is an alternative globalization possible? Politics and Society, 36: 271305

Eysenck, H. J. (1976) Introduction. In H. J. Eysenck (Ed.), Case studies in behaviour therapy. London: Routledge and Kegan

Fairclough, N. (1992) Discourse and social change. Cambridge: Polity Press.

Fairhead, J., M. Leach, \& I. Scoones. (eds) (2012) Special issue on 'Green grabbing'. Journal of Peasant Studies 39(2).

Fakih, M. (1996) Masyarakat sipil untuk transformasi sosial: pergolakan ideologi LSM Indonesia. Pustaka Pelajar.

Falen, D. J. (2014) The Other Gender? Reflections on Fieldwork in Benin, Men and Masculinities, 11, 2, 164-173.

Faria, C. \& Mollett, S. (2014) Critical feminist reflexivity and the politics of whiteness in the 'field'. Gender, Place \& Culture, 2, 1-15

Farley, J., \& Costanza, R., (2010) Payments for ecosystem services: fromlocal to global. Ecol. Econ. 69, 2060-2068.

Farmer, P. (2004) An Anthropology of Structural Violence. Current Anthropology, 45: 305-25.

Federici, S. (2004) Caliban and the Witch: Women, the Body and Primitive Accumulation. New York: Autonomedia

Ferber, M.A. \& Nelson, J.A. (2009) Beyond Economic Man: Feminist Theory and Economics. University of Chicago Press

Ferguson, J. (2005) Seeing like an oil company: Space, security and global capital in neoliberal Africa. American Anthropologist, 107(3): 377-382

Ferguson, J. (2009) The uses of neo-liberalism. Antipode 41, S1, 166-184. 
Figueres, C. (2013) Climate policy: a new foundation of stability and prosperity. Climate Policy, 13(5): 538-540

Fisher, B., Turner, R.K., \& Morling, P. (2009) Defining and classifying ecosystem services for decision making. Ecological Economics 68, 643-653

Fletcher, R. (2010) Neoliberal Environmentality: Towards a Poststructuralist Political Ecology of the Conservation Debate, Conservation and Society, 8 (3): 171-81

Fletcher, R. (2012) Capitalizing on Chaos: Climate change and disaster capitalism. Ephemera, 12 (1/2): 97-112

Fletcher, R. (2012) Using the master's tools? Neoliberal conservation and the evasion of inequality, Development and Change 43 295-317

Fletcher, R. (2013) How I learned to stop worrying and love the market: Virtualism, disavowal, and public secrecy in neoliberal environmental conservation. Environment and Planning D: Society and Space, 31(5), 796-812

Fluri, J. (2011) Armored peacocks and proxy bodies: gender geopolitics in aid/development spaces of Afghanistan. Gender, Place \& Culture 18, 519-536.

Flyvbjerg, B. (2011) Case Study, in Denzin, N. K. \& Lincoln, Y. S. eds. The Sage Handbook of Qualitative Research, 4th ed, Sage, Chapter 17: 301-316

Foucault, M. (1977) Discipline and Punish: The Birth of the Prison, Vintage, New York

Foucault, M. (1980) Power/Knowledge: Selected Interviews and Other Writings 19721977. Sussex: Harvester Press

Foucault, M. (1984) On the genealogy of ethics: an overview of work in progress, in The Foucault Reader edited by Paul Rabinow. New York: Pantheon, 340-72

Foucault, M. (2008) The birth of biopolitics. New York: Palgrave Macmillan

Fox J. C., Vieilledent G., Yosi C. K., Pokana J. N. \& Keenan A. R. J. (2011) Above ground forest carbon dynamics in papua new guinea: isolating the influence of selectiveharvesting and El Nino. Ecosystems 14, 1276-88 
Fraser, N. (2004) To interpret the world and to change it: an interview with Nancy Fraser. Signs 29, 1103-1124

Fraser, N. (2009) Feminism, capitalism and the cunning of history. New Left Review, 56, 97-117

Fraser, N. (2013) Fortunes of Feminism: From State-Managed Capitalism to Neoliberal Crisis, Verso Books: New York

Frey, B. S. \& Oberholzer-Gee, F. (1997) The cost of price incentives: an empirical analysis of motivation crowding-out. American Economic Review 87, 746-755

Frey, B.S., Oberholzer-Gee, F. \& Eichenberger, R. (1996) The old lady visits your backyard: a tale of morals and markets. Journal of Political Economy, 104, 1297-1313

Galtung, J. (1969) Violence, peace, and peace research. Journal of Peace Research, 6(3), 167-191.

Galudra, G., M. van Noordwijk, S. Suyanto, I. Sardi, U. Pradhan, \& D. Catacutan (2011) Hot spots of confusion: contested policies and competing carbon claims in the peatlands of Central Kalimantan, Indonesia, 13(4):431-441.

Gamu, J. Le Billon, P. \& Spiegel, S. (2015) Extractive industries and poverty: A review of recent findings and linkage mechanisms. The Extractive Industries and Society, 2(1), $162-176$

Geisler, C. C. (1995) Land and poverty in the United States: Insights and oversights. Land Economics 71 (1): 16-34

Gerber, J. F. (2013) The Hidden Consequences of Credit: An Illustration from Rural Indonesia. Development and Change, 44(4), 839-860.

Ghazoul, J., Butler, R. A., Mateo-Vega, J., \& Koh, L. P. (2010) REDD: A reckoning of environment and development implica- tions. Trends in Ecology \& Evolution, 25: 396402

Ghosh, K. (2006) Between Global Flows and Local Dams : Indigenousness , Locality , and the Transnational Sphere in Jharkhand , India, 21(4), 501-534. 
Giard, L. (1998) Doing cooking. In The practice of everyday life volume 2: Living and cooking, ed. M. De Certeau, L. Giard, and P. Mayoll, 149-247. Minneapolis, MN: University of Minnesota Press.

Gibson-Graham, J. K. (2000) Poststructural interventions. In E. Sheppard \& T. J. Barnes (Eds.), A Companion to Economic Geography (95-110). Oxford: Malden, Massachusetts: Blackwell.

Gibson-Graham, J. K. (2002). Economic politics beyond the binary frame. In A. Herod and M. Wright (eds), Geographies of Power: Placing Scale, Oxford: Blackwell Publishers,

Gibson-Graham, J. K. (2013) Take back the economy: An ethical guide for transforming our communities. Minneapolis: University of Minnesota Press

Giddens, A. (1990) The Consequences of Modernity. Polity Press, Cambridge

Gilbert, J. \& Beckley, T. M. (1993) Ownership and Control of Farmland: Landlord-Tenant Relations in Wisconsin. Rural Sociology, 58: 569-579

Glassman, J. (2006) Primitive accumulation, accumulation by dispossession, accumulation by extra-economic means. Progress in Human Geography 30(5):608-625

GCP (Global Canopy Programme). (2015) The REDD Desk: Indonesia, http://theredddesk.org/countries/indonesia/, Accessed online (10 January, 2015)

Goetz, A. M. (2007) Political Cleaners: Women as the New Anti-Corruption Force? Development and Change, 38: 87-105

Golledge, R. G. (1973) Some issues related to the search for geographical knowledge. Antipode, 5: 60-66

Gore, A. (2015) Al Gore: 'climate change deniers won't win', Guardian Interviews - The Guardian UK. https://www.youtube.com/watch?v=x_WMEsHaQaE. Accessed Online (16 July 2015)

Grajales, J. (2011) The rifle and the title: paramilitary violence and land control in Colombia. Journal of Peasant Studies, 38(4), 771-92 
Gramsci, A. (1985) Selections from Cultural Writings. Cambridge, MA: Harvard University Press

Gregersen, H., H. Lakany, A. Karsenty, \& A. White. (2010) Does the opportunity cost approach indicate the real cost of REDD+? Rights and realities of paying for REDD+. Unpublished.

Gregorio, M. Di, Brockhaus, M., Cronin, T., Muharrom, E., Santoso, L., \& Mardiah, S. (2013) Equity and REDD + in the Media: a Comparative Analysis of Policy. Ecology and Society 18(2): 39.

Gregory, D. (2004) The Colonial Present: Afghanistan, Palestine, Iraq. Oxford, UK: Blackwell

Gregson, N. \& Rose, G. (2000) Taking Butler elsewhere: Performativities, spatialities and subjectivities. Environment and Planning D: Society and Space 18: 433-452

Grubb, M., Vrolijk, C., \& Brack, D. (1999) The Kyoto Protocol: A Guide and Assessment. Royal Institute of International Affairs, London

Gudynas, E. (2011) Buen vivir: Today's tomorrow. Development, 54(4), 441-447

Guggenheim, S. (2004) Crises and Contradictions: Understanding the Origins of a Community Development Project in Indonesia. Jakarta: Mimeo

Gunawan, A. (2015) Illegal mining causing over Rp 80t in losses - Jakarta Post, http://www.thejakartapost.com/news/2015/05/05/illegal-mining-causing-over-rp80t-losses.html, Accessed Online (6 May 2015)

Gupta, A., E. Lövbrand, E. Turnhout, \& M.J. Vijge, (2012) In pursuit of carbon accountability: The politics of REDD+ measuring, reporting and verification systems, Current Opinion in Environmental Sustain- ability 4(6): 726-731

Hajer, M. (1995) The Politics of Environmental Discourse: ecological modernisation and the policy process. Oxford: Clarendon Press

Hale, C. (2008) Engaging Contradictions: Theory, Politics, and Methods of Activist Scholarship. University of California Press 
Hall, D. (2012) Rethinking Primitive Accumulation: Theoretical Tensions and Rural Southeast Asian Complexities. Antipode, 44(4), 1188-1208

Hall, D. (2013) Land. Polity Press

Hall, D., P. Hirsch \& T. M. Li, (2011) Powers of exclusion: land dilemmas in Southeast Asia. Singapore and Honolulu: National University of Singapore Press and University of Hawai'i Press

Harding, S. \& Norberg K. (2005) New feminist approaches to social science methodologies: an introduction. Signs 30, 2009-2015

Hardt, M. \& Negri, A. (2009) Commonwealth. Cambridge: Harvard University Press.

Hardt, M. (2011) The militancy of theory, South Atlantic Quarterly 110(1): 19-35

Harris, L. (2006) Irrigation, gender, and social geographies of the changing waterscapes of southeastern Anatolia. Environment and Planning D: Society and Space 24, 187-213

Hartsock, N. (2006) Globalization and primitive accumulation: the contributions of David Harvey's dialectical Marxism. In Castree, N. and Gregory, D. eds. David Harvey: A Critical Reader. Malden: Blackwell, 167-190

Harvey, D. (1996) Justice, Nature and the Geography of Difference. London: WileyBlackwell,

Harvey, D. (2003) The New Imperialism. Oxford: Oxford University Press

Harvey, D. (2005), A Brief History of Neoliberalism, Oxford University Press

Harvey, D. (2012) Rebel Cities: From the Right to the City to the Urban Revolution. London: Verso.

Harvey, D. (2014) The Seventeen Contradictions of Capitalism. Profile Books.

Hay, I. (2010) Qualitative research methods in human Geography. Oxford University Press, Oxford 
Hays-Mitchell, M. (2005) Women's struggles for sustainable peace in post-conflict Peru: A feminist analysis of violence and change, in Nelson, L. and Seager, J. (eds) A companion to feminist geography Blackwell, Malden MA, 590-606

Heinemann, T. (2013) Carbon Crooks (film), BritDoc

Herod, A. \& Wright, M. W. (2002) Geographies of power: placing scale. Malden: Blackwell Publishing

Heryanto, A. (2006) State Terrorism and Political Identity in Indonesia: Fatally Belonging. NewYork: Routledge

Hirsch, P. (2011) Re-agrarianisation or repositioning agrarian relations? In Vaddhanaphuti, C. and Wittayapak, C. (eds) Revisiting Agrarian Transformations in the Greater Mekong Sub-Region. Regional Centre for Social Science and Sustainable Development, Chiang Mai University, Chiang Mai, 185-190.

Hirsch, P. (2012) Reviving Agrarian Studies in South-East Asia: Geography on the Ascendancy. Geographical Research, 50(4), 393-403

Hoang, M. H., Do, T. H., Pham, M. T., van Noordwijk, M., \& Minang, P. A. (2013) Benefit distribution across scales to reduce emissions from deforestation and forest degradation (REDD+) in Vietnam. Land Use Policy, 31(1)

Hoggart, K., Lees, L. \& Davies, A. (2002) Researching human Geography. London: Arnold

Holmes, C. (2013) Ignorance, denial, internalisation and transcendence: A poststructural perspective on Polanyi's double-movement, 39, 273-290

Hospes, 0. (1992) People that count: The forgotten faces of rotating savings and credit associations in Indonesia. Savings and Development. 16(4):371-401

Howson, P. \& Kindon, S. (2015) Analysing access to the local REDD+ benefits of Sungai Lamandau, Central Kalimantan, Indonesia, Asia Pacific Viewpoint, 56(1): 96-110

Howson, P. (2013) Over the REDD+ Rainbow - Jakarta Post, Accessed online (10 May 2014): http://www.thejakartapost.com/news/2013/08/15/over-redd-rainbow.html 
Hugo, G. (1995) Labour export from Indonesia. ASEAN Economic Bulletin, 12(2), 275298.

Hyndman, J. \& Walton-Roberts, M. (2000) Interrogating borders: A transnational approach to refugee research in Vancouver. The Canadian Geographer 44, (3): 244-58

Hyndman, J. (1997) Border Crossings. Antipode, 29, 149-176

Hyndman, J. (2001) The Field as Here and Now, Not There and Then. Geographical Review 91 (1-2): 262-272

Hyndman, J. (2004) Mind the gap: bridging feminist and political Geography through geopolitics. Political Geography 23, 307-322

Hyndman, J. (2007) The securitization of fear in post-tsunami Sri Lanka. Annals of the Association of American Geographers 97: 361-72

ICRAF (2010) Exploration of Landscape Dynamics in the Buffer Area of Lamandau River Wildlife Reserve and its neighboring area, Central Kalimantan, using the FALLOW $\begin{array}{lllll}\text { model. } & \text { Accessed } & 2013 & \text { March }\end{array}$ http://www.worldagroforestrycentre.org/regions/southeast_asia/.

Igoe, J. (2004) Conservation and Globalization: A Study of National Parks and Indigenous Communities from East Africa to South Dakota (Belmont, CA: Wadsworth/Thompson)

Igoe, J., Neves, K. and Brockington, D. (2010) A Spectacular Eco-Tour around the Historic Bloc: Theorising the Convergence of Biodiversity Conservation and Capitalist Expansion. Antipode, 42: 486-512

Indrarto, G.B., P. Murharjanti, J. Khatarina, I. Pulungan, F. Ivalerina, J. Rahman, M.N. Prana, I.A.P. Resosudarmo, E. Muharrom, (2012) The Context of REDD+ in Indonesia: Drivers, Agents and Institutions. Working Paper 92. CIFOR, Bogor.

Innes, T. (2014) Did I say this land is your land? Patterns of contention in Indonesian environmental disputes. Unpublished thesis - University of Mamyland 
IPCC. (2007) Climate Change 2007: Climate Impacts, Adaptation and Vulnerability, Contribution of Working Group II to the Intergovernmental Panel on Climate Change Fourth Assessment Report. Intergovernmental Panel on Climate Change: Geneva

Jackson, C. (2007) Resolving risk? Marriage and creative conjugality. Development and Change 38 (1), 107-129

Jacobs, S. (2010) Gender and agrarian reforms. London: Routledge

Jagger, P., Atmadja, S., Pattanayak, S.K., Sills, E. \& Sunderlin, W.D. (2009) Learning while doing: Evaluating impacts of REDD+ projects. In: Angelsen, A. (ed.) Realising REDD+: national strategy and policy options, 281-292. CIFOR, Bogor, Indonesia.

Jiwani, Y. (2006) Discourses of denial: Meditations of race gender and violence. Vancouver: University of British Columbia Press

Jones, J. P., Woodward. K, \& Marston, S. A. (2007) Situating flatness. Transactions of the Institute of British Geographers, 32: 264-276

Jong, H. N. (2014) Govt to increase jurisdictional approach to tackling environmental problems - Jakarta Post. Accessed Online, (15 December 2014) http://www.thejakartapost.com/news/2014/11/11/govt-increase-jurisdictionalapproach-tackling-environmental-problems.html\#sthash.I7Jrf204.dpuf.

Joshi, L., van Noordwijk, M. \& Pradhan, U. (2010) Investment in carbon stocks in the eastern buffer zone of Lamandau River Wildlife Reserve , Central Kalimantan province, Indonesia : a REDD + feasibility study. Accessed 15 December 2013 from: http://theredddesk.org/sites/default/files/lamandau_report_final_version.pdf.

Juniper, T. (2012) We must put a price on nature if we are going to save it - Guardian UK. http://www.theguardian.com/environment/2012/aug/10/nature-economic-valuecampaign

Kandiyoti, D. (1998) Gender power and contestation: rethinking bargaining with patriarchy. In: Jackson, C., Pearson, R. (Eds.), Feminist Visions of Development; Gender Analysis and Policy. Routledge, London, 135-152 
Karim, W. (1995) Bilateralism and gender in Southeast Asia. In: Karim, W. (Ed.), 'Male' and 'Female' in Developing Southeast Asia. Berg Publishers, Oxford, 35-74

Katerere, Y. (2010) A climate change solution? World Finance, May-June, 104-106

Katz, C. (2001) On the grounds of globalization: A topography for feminist political engagement. Signs 26, 1213-1234

Kearns, G. (2013) Beyond the legacy of Mackinder, Geopolitics 18 (4): 917-932

Kelly, A. B. (2011) Conservation practice as primitive accumulation. Journal of Peasant Studies, 38(4), 683-701

Kesby, M. (2007) Spatialising participatory approaches: the contribution of Geography to a mature debate Environment and Planning A 39(12) 2813 - 2831

Kiang, P. N. (2008) Crouching Activists, Hidden Scholars (eds. Hale, C. (2008) Engaging Contradictions: Theory, Politics, and Methods of Activist Scholarship. (299-319). University of California Press

Kindermann, G., Obersteiner, M., Sohngen, B., Sathaye, J., Andrasko, K., \& Rametsteiner, E. (2008) Global cost estimates of reducing carbon emissions through avoided deforestation. Proceedings of the National Academy of Sciences, 105, 10302-10307.

Kindon, S. L. (1993) From Tea Makers to Decision Makers: Applying Participatory Rural Appraisal to Gender and Development in Rural Bali, Indonesia. (Unpublished MA Thesis) University of Waterloo

Kindon, S. L. (2012) Thinking-through-complicity with Te Iwi o Ngoti Hauiti: towards a critical use of participatory video for research (Unpublished PhD Thesis), University of Waikato.

King, B. H. (2007) Conservation and community in the new South Africa: a case study of the Mahushe Shongwe game reserve. Geoforum, 38 (1), 207-219.

Kitchin, R. \& Tate, N. J. (2000) Conducting Research into Human Geography: Theory, Methodology and Practice. Harlow, UK: Prentice Hall.

Klein, N. (2008) The Shock Doctrine: The Rise of Disaster Capitalism, London: Penguin 
Klein, N. (2014) This Changes Everything: Capitalism vs. The Climate, Simon \& Schuster: New York

Klein, N. (2015) This Changes Everything - Guardian Books Event, London (25 March 2015)

Klein, N. \& Smith, N. (2008) The shock doctrine: A discussion. Environment and Planning D. 26, 582-95

Knigge, L., \& Cope, M. (2006) Grounded visualization: integrating the analysis of qualitative and quantitative data through grounded theory and visualization. Environment and Planning A, 38(11), 2021-2037.

Knight, D. M. (2013) Opportunism and Diversification: Entrepreneurship and Livelihood Strategies in Uncertain Times. Ethnos, 80(1), 117-144

Kobayashi, A. (2003) GPC ten years on: Is self-reflexivity enough? Gender, Place and Culture, 10(4), 345-349.

Koopman, S. (2011) Let's take peace to pieces. Political Geography, 30 193-4

Kosoy, N., \& E. Corbera (2010) Payments for ecosystem services as commodity fetishism. Ecological Economics, 69(6):1228-1236.

Krause, T., Collen, W. \& Nicholas, K. A. (2013) Evaluating Safeguards in a Conservation Incentive Programme : Participation, Consent, and Benefit Sharing in Indigenous Communities of the Ecuadorian Amazon, 18(4).

Krishna, S. (2004) A 'genderscape' of community rights in natural resource management'. In S. Krishna (ed.) Livelihood and Gender: Equity in Community Resource Management, New Delhi: Sage Publications, 17-63

Kunreuther, H. \& Easterling, D. (1990) Are Risk-Benefit Tradeoffs Possible in Siting Hazardous Facilities? American Economic Review, May 1990 (Papers and Proceedings), $80(2), 252-56$

Lacan, J. (1977) Escrits. Alan Sheridan (Trans.). Norton, New York 
Lakoff, G. (1986) Frame semantic control of the coordinate structure constraint. In CLS22, Part 2: Papers from the Parasession on Pragmatics and Grammatical Theory at the Twenty-Second Annual Regional Meeting, (152-167), Chicago. Chicago Linguistic Society.

Lang, C. (2015) REDD safeguards: What are they? - REDD Monitor. http://www.reddmonitor.org/2015/03/20/redd-safeguards-what-are-they/. Accessed Online (12 June 2015)

Lang, M., Fernando, L., Buxton, N., Szucs, I., \& Grupo Permanente de Trabajo sobre Alternativas al Desarrollo. (2013) Beyond development alternative visions from Latin America. Amsterdam: Transnational Institute; Rosa Luxemburg Foundation. http://rosalux-europa.info/userfiles/file/Beyond__ Development_RLS_TNI_2013.pdf. Accessed Online (1 September 2014)

Larson, A. M. (2011) Forest tenure reform in the age of climate change: lessons for REDD+. Global Environ. Change 21 (2), 540-549.

Latour, B. (2005) Reassembling the Social: An Introduction to Actor-Network Theory. Clarendon, Oxford

Law, J. (2004) After Method: Mess in Social Science Research. London: Routledge Lawson, V. (2007) Making Development Geography. Hodder Arnold, London Le Blanc, D. (2011) Special issue on green economy and sustainable development. Natural Resources Forum, 35(3): 151-154.

Leach, M., R. \& Scoones, I. (2015) Political Ecologies of Carbon in Africa (1-42). In (eds) Carbon Conflicts and Forest Landscapes in Africa. Routledge: New York,

Leach, M., R. Mearns, \& I. Scoones (1999) Environmental entitlements: Dynamics and institutions in community-based natural resource management. World Development, 27(2): 225-247.

Leal, P. A. (2007). Participation: The Ascendancy of a Buzzword in the Neo-Liberal Era. Development in practice, 17(4): 539-548. 
Lederer, M. (2011) From CDM to REDD+: What do we know for setting up effective and legitimate carbon governance? Ecological Economics, 70(11), 1900-1907

Lees, L. (2004) Urban Geography: discourse analysis and urban research. Progress in Human Geography, 28(1), 101-107

Lemke, Thomas. (2011) Biopolitics: An Advanced Introduction. New York: NYU Press

Levien, M. (2007) India's Double-movement: Polanyi and the National Alliance of Peoples Movements, Berkeley Journal of Sociology, 51, 119-49

Levien, M., \& Paret, M. (2012) A second double-movement? Polanyi and shifting global opinions on neoliberalism. International Sociology, 27(6): 724-744

Levy, A. (2006) [1993] Nazi Hunter: The Wiesenthal File (Revised 2002 ed.). London: Constable \& Robinson.

Li, T. M. (1996) Images of community: Discourse and strategy in property relations. Development and Change, 27:501-527

Li, T. M. (2000) Articulating Indigenous Identity in Indonesia: Resource Politics and the Tribal Slot. Comparative Studies in Society and History 42 (1):149-179

Li, T. M. (2002) Engaging Simplifications: Community-Based Resource Management, Market Process and State Agendas in Upland Southeast Asia, World Development 30(2), 265-83

Li, T. M. (2007) The will to improve: Governmentality, development, and the practice of politics. Duke University Press.

Li, T. M. (2010) Indigeneity, Capitalism, and the Management of Dispossession. Current Anthropology, 51(3):385-414.

Li, T. M. (2014a) What is land? Assembling a resource for global investment. Transactions of the Institute of British Geographers, doi: 10.1111/tran.12065

Li, T. M. (2014b) Land's End: Capitalist Relations on an Indigenous Frontier. Duke University Press. 
Lindhjem, H., G. Bråten, A. Gleinsvik, \& I. Aronsen (2010) Experiences with Benefit Sharing: Issues and Options for REDD-plus. Econ Pöyry and Vista report R-2010-018.

Lindhjem, H., I. Aronsen, K. G. Bråten, \& A. Gleinsvik. (2010) Experiences with benefit sharing: issues and options for REDD-plus. Pöyry, Oslo, Norway

Liverman, D., (2004) Who Governs, at What Scale and at What Price? Geography, environmental governance, and the commodification of nature. Annals of the Association of American Geographers, 94 (4): 734-738

Lo, A. (2013) Carbon trading in a socialist market economy: Can China make a difference? Ecological Economics, 87:72-74.

Locke, T. (2004) Critical Discourse Analysis. Bloomsbury: London

Lohmann, L. (2008) Carbon Trading, Climate Justice and the Production of Ignorance: Ten examples. Development, 51:359-365.

Lohmann, L., \& Bohm, S. (2012) Critiquing carbon markets: A conversation, Ephemera 12 (1): 81-96

Lohmann, L., (2009) Neoliberalism and the calculable world: The rise of carbon trading. In: Bohm, S. \& Dabhi S. (Eds) Upsetting the offset: the political economy of carbon markets, London: Mayfly books, 25-40.

Lokollo, E. M., I. Rusastra, H. P. Saliem, S. S. Friyanto \& G.S. Budhi. (2007) Dinamika Sosial Ekonomi Pedasaan: Analisis Perbandingan Antar Sensus Pertanian. Bogor. Pusat Analysis Sosial Eknomi dan Kebijakan Pertanian Badan Penelitian dan Pengembangan Pertanian Departmen Pertanian.

Louis, R. P. (2007) Can you gear us now? Voices from the margin: Using indigenous methodologies in geographic research. Geographical Research, 45(2), 130-139

Lounella, A. (2015) Climate change disputes and justice in Central Kalimantan, Indonesia, Asia Pacific Viewpoint 56(1): 62-78

Lovell, H., H. Bulkeley, \& D. Liverman (2009) Carbon offsetting: Sustaining consumption? Environment and Planning A, 41:2357-2379. 
Lund, C. (2002) Negotiating Property Institutions: On the Symbiosis of Property and Authority in Africa, in K. Juul \& C. Lund (eds) Negotiating Property in Africa, 11-43. Portsmouth, NH: Heinemann.

Lund, C. (2011) Fragmented sovereignty: land reform and dispossession in Laos. Journal of Peasant Studies, 38(4), 885-905

Luttrell, C., Loft, L., Fernanda Gebara, M., Kweka, D., Brockhaus, M., Angelsen, A., \& Sunderlin, W. D. (2013) Who should benefit from REDD?? Rationales and realities. Ecology and Society, 18(4): 52

Lynam, T., de Jong, W., Sheil, D., Kusumanto, T. \& Evans, K. (2007) A Review of tools for incorporating community knowl- edge, preferences, and values into decision making in natural re- sources management, Ecology and Society, 12, 5

MacDonald, K. I. (2013) Grabbing 'green': cynical reason, instrumental ethics and the production of 'the green economy'. Human Geography 6 (1): 46-63.

Mackenzie, F. (1993) A piece of Land Never Shrinks: Reconceptualising Land Tenure in a Smallholding District Kenya. In: Basset, T.J., Crummey, D. (Eds.), Land in African Agrarian Systems. University of Wisconsin Press, Madison, 194-221

MacKenzie, J. M. (1988) The Empire of nature: hunting, conservation and British imperialism. Manchester, UK: Manchester University Press

MacKinder, H. J. (1904) The geographical pivot of history. The Geographical Journal, 23, 421-437

MacPherson, C.B. (1978) Property: mainstream and critical positions. Oxford: Basil Blackwell.

Mahanty, S., \& McDermott, C. L. (2013) How does "Free, Prior and Informed Consent" (FPIC) impact social equity? Lessons from mining and forestry and their implications for REDD+. Land Use Policy, 35, 406-416

Mahanty, S., Tacconi, L. \& Suich, H. (2013), Access and benefits in payments for environmental services and implications for REDD+: lessons from seven PES schemes, Land Use Policy, 31, 38-47 
Malhi, A. (2011) Making spaces, making subjects: land, enclosure and Islam in colonial Malaya. Journal of Peasant Studies 38: 727-746

Maller, C., \& Strengers, Y. (2013) The global migration of everyday life: Investigating the practice memories of Australian migrants. Geoforum, 44, 243-252

Mansvelt, J., \& Berg, L. D. (2010) Writing qualitative geographies, constructing meaningful geographical knowledges. In I. Hay (Ed.), Qualitative Research Methods in Human Geography (3rd ed., pp. 333-355). Oxford; New York: Oxford University Press.

Maraseni, T. N., \& Cadman, T. (2015) A comparative analysis of global stakeholders' perceptions of the governance quality of the clean development mechanism (CDM) and reducing emissions from deforestation and forest degradation (REDD+). International Journal of Environmental Studies, (March 2015), 1-17

Margono, B. A., Potapov, P. V, Turubanova, S., Stolle, F., \& Hansen, M. C. (2014) Primary forest cover loss in Indonesia over 2000-2012, 4 (June), 730-735.

Marino, E., \& Ribot, J. (2012) Special Issue Introduction: Adding insult to injury: Climate change and the inequities of climate intervention. Global Environmental Change, 22(2), $323-328$.

Marston, S. A. (2000) The social construction of scale. Progress in Human Geography, 24(2), 219-242

Marston, S. A., Jones, J. P. \& Woodward, K. (2005) Human Geography without scale. Transactions of the Institute of British Geographers, 30: 416-432

Marston, S., Jones, J., \& Woodward, K. (2005) Human Geography without scale. Transactions of the Institute of British Geographers NS 30, 416-32

Marston, S., Woodward, K. \& Jones, P. J. (2008) Flattening ontologies of globalization: The Nollywood Case. In Archer, K., Bosman, M., Amen, M. M. \& Schmidt, E. (2008) Cultures of Globalization. Routledge: New York

Martinez-Alier, J., Pascual, U., Vivien, F.-D., \& Zaccai, E. (2010) Sustainable de-growth: Mapping the context, criticisms and future prospects of an emergent paradigm. Ecological Economics, 69(9), 1741-1747. 
Marx, K. \& F. Engels (1992) The Communist Manifesto. Oxford: Oxford University Press.

Marx, K. (1888) Theses On Feuerbach, Marx/Engels Selected Works, Volume One, (13 15). Progress Publishers: Moscow,

Massaro, V. A. \& Williams, J. (2013) Feminist geopolitics. Geography Compass, 7, 567577

Massey, D. (1999) Spaces of politics. In D. Massey, J. Allen, \& P. Sarre (Eds.), Human Geography today (279-294). Cambridge: Polity Press

Massey, D. (2005) For Space. London: SAGE

Matulis, B. (2014) The economic valuation of nature: a question of justice? Ecological Economics 104 (1): 155-157.

McAfee, K. (1999) Selling Nature to Save it? Biodiversity and green developmentalism. Environment and Planning D, 17 (1): 133-154

McAfee, K. (2014) The post and future politics of green economy and REDD? In B. Stephan \& R. Land (Eds.), The Politics of Carbon Markets (pp. 237-260). Routledge: Earthscan

McAfee, K. (2015) Green economy and carbon markets for conservation and development: a critical view, International Environmental Agreements: Politics, Law and Economics 15(2): 1-21

McAfee, K. \& Shapiro. E. N. (2010) Payments for ecosystem services in Mexico: nature, neoliberalism, social movements, and the state. Annals of the Association of American Geographers, 100: 579-99

McCarthy, J. F. (2012) Swimming Upstream: Local Indonesian Production Networks in Globalized Palm Oil Production. World Development, 40(3): 555-569.

McCarthy, J.F., Vel, J.A.C., \& Afiff, S. (2012) Trajectories of land acquisition and enclosure: Development schemes, virtual land grabs, and green acquisitions in Indonesia's Outer Islands, The Journal of Peasant Studies 39(2): 521-549. 
McDermott, C. L., L. Coad, A. Helfgott, \& H. Schroeder, (2012) Operationalizing social safeguards in REDD+: actors, interests and ideas. Environmental Science \& Policy $21: 63-72$

McDermott, C.L. (2014) REDDuced: From sustainability to legality to units of carbonThe search for common interests in international forest governance. Environmental Science \& Policy, 35:12-19.

McDermott, M., S. Mahanty, \& K. Schreckenberg. (2013) Examining equity: a multidimensional framework for assessing equity in payments for ecosystem services. Environmental Science and Policy 33:416-27

McDowell, L. (2010) Interviewing: fear and liking in the field. In D. DeLyser, S. Herbert, S. Aitken, M. Crang \& L. McDowell (Eds.), The SAGE Handbook of Qualitative Geography 156-172. London: SAGE.

McGee, B. (2009) The community referendum: participatory democracy and the right to free, prior and informed consent to development. Berkeley Journal of International Law $27,570-635$

McGlennon, S. (2015) Governance of international trade in environmentally-significant products (Unpublished PhD Thesis), Australia National University

McGregor, A. (2005) Negotiating nature: exploring discourse through small group research. Area, 37(4), 423-432.

McGregor, A. (2012) Green and redd? Human Geography, 3 (2): 21-34.

McGregor A, Challies, E., Howson, P., Astuti, R., Dixon, R., Haalboom, B., Gavin, M., Tacconi, L., \& Afiff, S., (2015) Beyond carbon, more than forests: REDD+ governmentality in Indonesia Environment \& Planning A, 47(1) 138-155;

McGregor, A., Weaver, S., Challies, E., Howson, P., Astuti, R., \& Haalboom, B. (2014) Practical critique: Bridging the gap between critical and practice oriented REDD+ research communities, Asia Pacific Viewpoint, 55(3) 277-291;

McKenzie, F. (2014) Simply REDD+. Accessed 1 July 2014 from http://unredd.wordpress.com/2014/06/01/simply-redd-2/. 
Meah, A. \& Jackson, P. (2012) Crowded kitchens: The democratisation of domesticity? Gender, Place and Culture, 20, 5, 578-596

Meah, A. (2013) Reconceptualizing power and gendered subjectivities in domestic cooking spaces. Progress in Human Geography, 38, 5, 671-690

Mendez, B. (2008) Engaging Contradictions: Theory, Politics, and Methods of Activist Scholarship. University of California Press

Miles, W. (2014) Revaluing Rainforests: The Political Ecology of Market-Based Conservation (Un-published PhD Thesis), University of Hawaii.

Milne, S. \& Niesten E. (2009) Direct Payments for Biodiversity Conservation in Developing Countries: Practical Insights for Design and Implementation, Oryx 43(4): $530-41$

Milne, S. (2012) Grounding Forest Carbon: Property Relations and Avoided Deforestation in Cambodia. Human Ecology, 40, 693-706

Milne, S., \& Adams B. (2012) Market Masquerades: Uncovering the Politics of Community-level Payments for Environmental Services in Cambodia, 43(1):133-158

Mitchell, T. (1991) The limits of the state: beyond statist approaches and their critics. The American Political Science Review, 85(1), 77-96

Mitchell, T. (2002) Rule of experts: Egypt, technopolitics, modernity. Berkeley: University of California Press.

Mitchell, T. (2008) Rethinking economy. Geoforum, 39, 1116-21.

Mitchell, T. (2009) When Markets are Poison, The Corner House (September), 1-68.

Mohammed, E. Y. (2011) Pro-poor Benefit Distribution in REDD: Who Gets What and Why Does it Matter? REDD Working Papers. International Institute for Environment and Development, London

Monbiot, G. (2015) China Syndrome. http://www.monbiot.com/2015/06/14/chinasyndrome/. Accessed Online (25 March 2015) 
Mosse, D. (1994) Authority, Gender and Knowledge: Theoretical Reflections on the Practice of Participatory Rural Appraisal. Development and Change, 25: 497-526

Mosse, D. (1997) The symbolic making of a common property resource: History, ecology and locality in a tank-irrigated landscape in South India. Development and Change 28:467-504

Mountz, A. \& Hyndman, J. (2006) Feminist approaches to the global intimate. Women's Studies Quarterly, 34, 446-63

Mountz, A. (2011) Where asylum-seekers wait: feminist counter-topographies of sites between states. Gender, Place and Culture 18, 381-399

Mulia, R., Khasanah, N., Noordwijk, M. Van, Ekadinata, A., \& Zulkarnain, M. T. (2010) Exploration of Landscape Dynamics in the Buffer Area of Lamandau River Wildlife Reserve and its neighboring area , Central Kalimantan , using the FALLOW model, 2009.

Mulrennan, M. E. (2008) Reaffirming Community In the context of community-based conservation. In: Brydon, Diana, Coleman, William D. (Eds.), Renegotiating Community: Interdisciplinary Perspectives, Global Contexts. UBC Press, Vancouver

Mulyani, M. \& P. Jepson (2015) Social learning through a REDD+ 'village agreement': Insights from the Kalimantan Forests Climate Partnership (KFCP) in Indo- nesia, Asia Pacific Viewpoint 56(1): 79-95

Münster, D., \& Münster, U. (2012) Consuming the Forest in an Environment of Crisis: Nature Tourism, Forest Conservation and Neoliberal Agriculture in South India. Development and Change, 43(1), 205-227

Muradian, R., E. Corbera, U. Pascual, N. Kosoy, \& P. May (2010) Reconciling theory and practice: an alternative conceptual framework for understanding payments for environmental services. Ecological Economics, 69(6):1202-1208

Myers, R. (2011) Review of Powers of Exclusion: Land Dilemmas in Southeast Asia, Antipode Foundation, Open Access Book Reviews, https://radicalantipode.files.wordpress.com/2012/09/book-review_myers-on-hall-etal.pdf, Accessed Online (14 June, 2014) 
Nagar, R. (2003) Collaboration across borders: Moving beyond positionality. Singapore Journal of Tropical Geography, 24(3), 356-372

Nagar, R., Lawson, V., McDowell, L., \& Hanson, S. (2002) Locating globalization: feminist (re)readings of the subjects and spaces of globalization. Economic Geography 78 (3), 285-306.

Narayan, D., R. Chambers, M. K. Shah, \& P. Petesch, (2000) Voices of the Poor. Vol. I: Can Anyone Hear Us? Delhi: Oxford University Press and Washington, DC: World Bank

Nast, H. (1994) Women in the Field: Critical Feminist Methodologies and Theoretical Perspectives Professional Geographer, 46, 1, 54-66

National Geographic (2014) Stunning NASA Visualization Reveals Secret Swirlings of Carbon Dioxide, http://news.nationalgeographic.com/news/2014/11/141118-nasavideo-carbon-dioxide-global-warming-climate-environment/, Accessed online 12 April 2015

Neilson, J. (2013) A matter of life or death for the Indonesian nation? Inside Indonesia

Nel, A. \& Sharife, K. (2012) East African trees and the green resource curse. In: Bond, P. (Ed.), The CDM in Africa Cannot Deliver the Money: Why the Carbon Trading Gamble and 'Clean Development Mechanism' Won't Save the Planet from Climate Change, and How African Civil Society is Resisting. Centre for Civil Society, University of Kwa ZuluNatal, Durban, South Africa

Nel, A. (2014) Zones of Awkward Engagement in Ugandan Carbon Forestry. In Scoones, I., \& Leach, M. Carbon Forestry in Africa. University of Sussex

Nelson, I. L. (2013) The allure and privileging of danger over everyday practice in field research. Area, 45(4), 419-425

Nepstad, D. C., Boyd, W., Stickler, C. M., Bezerra, T., Azevedo, A. A. (2013) Responding to climate change and the global land crisis: REDD+, market transformation and lowemissions rural development. Phil Transactions Royal Society B, 368, 1-13

Neslen, A. (2015a) Subsidies to industries that cause deforestation worth 100 times more than aid to prevent it - The Guardian UK. 
http://www.theguardian.com/environment/2015/mar/31/subsidies-to-industriesthat-cause-deforestation-worth-100-times-more-than-aid-to-prevent-it, Accessed Online (15 April 2015)

Neslen, A. (2015b) Kyoto protocol's carbon credit scheme 'increased emissions by $600 \mathrm{~m}$ tonnes - The Guardian UK. http://www.theguardian.com/environment/2015/aug/24/kyoto-protocols-carboncredit-scheme-increased-emissions-by-600m-tonnes. Accessed Online (25 August 2015)

Newberry, J. (2006) Backdoor Java, State Formation and the Domestic in Working Class Java. Broadview Press, Peterborough, Ontario

Newton, J. \& Stacey, J. (1995) Ms. Representations: Reflections on studying academic men. In R. Behar \& D. Gordon (Eds.), Women writing culture (287-305). Berkeley: University of California Press.

Nicholls, R. (2009) Research and Indigenous participation: critical reflexive methods. International Journal of Social Research Methodology, 12(2), 117-126

Nielsen, T. D. (2013) The role of discourses in governing forests to combat climate change. International Environmental Agreements: Politics, Law and Economics, 14(3), 265-280.

Nightingale, A. J. (2006) The nature of gender: work, gender, and environment. Environment and Planning D: Society and Space 24, 165-185.

Nightingale, A. J. (2011) Bounding difference: Intersectionality and the material production of gender, caste, class and environment in Nepal. Geoforum, 42(2), 153-162

Nightingale, A. J., \& Ojha, H. R. (2013) Rethinking Power and Authority: Symbolic Violence and Subjectivity in Nepal's Terai Forests, 44(1): 29-51

Nkhata, B., A. Mosimane, L. Downsborough, C. Breen, \& D. Roux. (2012) A typology of benefit sharing arrangements for the governance of social-ecological systems in developing countries. Ecology and Society 17(1): 17. 
Norgaard, R.B. (2010) Ecosystem services: from eye-opening metaphor to complexity blinder. Ecological Economics 69, 1219-1227

Nussbaum, M.C. (2000) Women and Human Development: The Capabilities Approach. Cambridge: Cambridge University Press

O'Connor, M. (1994) On the misadventures of capitalist nature. In M O'Connor (ed) Is Capitalism Sustainable? Political Economy and the Politics of Ecology (125-151). London: Guilford

O’Lear, S. (2015) Climate science and slow violence: A view from political Geography and STS on mobilizing technoscientific ontologies of climate change. Political Geography, In-Press

O’Neill, J. (2006) Citizenship, Well-Being and Sustainability: Epicurus or Aristotle? Analyse \& Kritik, 28, 158-172.

O’Reilly, K. (2005) Ethnographic Methods, Routledge: London

O'Tuathail, G. (1996) Critical geopolitics: the politics of writing global space. London: Routledge

O'Tuathail, G., and S. Dalby, eds. (1998) Rethinking geopolitics. London and New York: Routledge.

Ojeda, D. (2012) Green pretexts: ecotourism, neoliberal conservation and land grabbing in Tayrona National Natural Park, Columbia. Journal of Peasant Studies 39(2), 357-75

Okereke, C., \& Dooley, K. (2010) Principles of justice in proposals and policy approaches to avoided deforestation: Towards a post-Kyoto climate agreement. Global Environmental Change, 20, 82-95

Pain, R. (2004) Social Geography: participatory research. Progress in Human Geography, 28(5): 652-663

Pain, R. (2009) Globalized fear:Towards an emotional geopolitics. Progress in Human Geography 33 (4): 466-86 
Pain, R. (2014) Everyday terrorism: Connecting domestic violence and global terrorism. Progress in Human Geography, 38, 531-50

Pain, R. \& Smith, S. J. (2008) Fear: critical geopolitics and everyday life. In: Pain, R. \& Smith, S. (eds) Fear: critical geopolitics and everyday life, Burlington: Ashgate, (1-24)

Pain, R. \& Staeheli, L. (2014) Introduction: intimacy-geopolitics and violence. Area, $46(4), 344-347$

Pant, P. (2011) Carbon, conservation, communities under sustainability (C3S) paradigm for forests. In The Economic, Social and Political Elements of Climate Change. SpringerVerlag.

Pawson, R., Wong, G. \& Owen, L. (2011) Known Knowns, Known Unknowns, Unknown Unknowns: The Predicament of Evidence-Based Policy. American Journal of Evaluation, 32: $518-46$

Peake, L. \& Trotz, A. (1999) Gender, Ethnicity and Place: Women and Identities in Guyana. New York: Routledge

Pearce, F. (2012) Land Grabbers: The Fight over Who Owns the Earth. Boston, MA: Beacon

Peck, J. (2010) Constructions of neoliberal reason. Oxford: Oxford University Press

Peet, R. \& M. Watts. (1996) Liberation ecology: Environment, development, social movements. London: Routledge.

Peet, R. (2013) Comparative policy analysis: Introduction, Human Geography, 6 (2): 110

Peet, R., Robbins, P., \& Watts, M. J. (2011) Global nature. In R. Peet, P. Robbins \& M. J. Watts (Eds.), Global Political Ecology (1-47). London; New York: Routledge.

Peluso, N. (1992) Rich Forests, Poor People: Resource Control and Resistance in Java. Berkeley, CA: University of California Press. Radhakrishnan,

Peluso, N. L. \& Vandergeest, P. (2001) Genealogies of the Political Forest and Customary Rights in Indonesia, Malaysia, and Thailand. Journal of Asian Studies 60 (3):761-812 
Peluso, N. L. (2007) Violence, Decentralization, and Resource Access in Indonesia. Peace Review, 19(1), 23-32.

Peluso, N. L., \& Lund, C. (2011) New frontiers of land control: Introduction. Journal of Peasant Studies, 38(4), 667-681.

Peskett, L. (2011) Benefit sharing in REDD+: exploring the implications for poor and vulnerable people. World Bank and REDD-net

Peskett, L., D. Huberman, E. Bowen-Jones, G. Edwards, \& J. Brown. (2008) Making REDD Work for the Poor. IUCN/ODI for the Poverty and Environment Partnership. Gland, Switzerland. http://www.odi.org.uk/resources/details.asp?id=2580\& title=makingredd-work-poor. Accessed Online (19 February, 2013)

Petherick, A. (2011) Refreshing REDD. Nature Climate Change, 1(9), 440-441

Pham, T.T., Di Gregorio, M., Carmenta, R., Brockhaus, M. \& Le, D.N. (2014) The REDD+policy arena in Vietnam: participation of policy actors. Ecol. Soc. 19

Phelps, J., Webb, E. \& Agrawal, A. (2010) Does REDD+ Threaten to Recentralize Forest Governance? Science Mag, 328 (1): 312-313

Pink, S. (2009) Doing Sensory Ethnography, Sage: London.

Pistorius, T., Schmitt, C.B., Benick. D., Entenmann, S., Reinecke. S., (2011) Greening REDD? - Challenges and opportunities for integrating biodiversity safeguards at and across policy levels. Ger J For Sci 182(5/ 6):82-98

Polanyi, K. (1944) The Great Transformation: The Political and Economic Origins of Our Time. Boston, MA: Beacon Press

PolHut. (2009) Pembalak ditangkap. Accessed 14 September 2013 from: https://polhut08.wordpress.com/2009/05/28/pembalak-suaka-margasatwalamandau-ditangkap-kalteng-pos-8-mei-2009/

Potter, L. (2012) New transmigration "paradigm" in Indonesia: Examples from Kalimantan. Asia Pacific Viewpoint, 53(3), 272-287

Povinelli, E. (2011) The governance of the prior. Interventions 13(1): 13-30 
Pratt, G. \& Rosner, V. (2006) Introduction: The Global and the Intimate. Women's Studies Quarterly 34 (1/2): 13-24

Pratt, G. (2009) Performativity. In D. Gregory, R. Johnson, G. Pratt, M. J. Watts \& S. Whatmore (Eds.), The Dictionary of Human Geography (526-527). Chichester: John Wiley and Sons.

PROFOR (2013) Working Paper - Integrating Communities into REDD+ in Indonesia, PROFOR: Washington

Proudhon, P. J. (1840/2011) What is property? An inquiry into the principle of right and of government. In I. McKay ed. Property is theft: a Pierre-Joseph Proudhon anthology, 87-138. Oakland: AK

Prudham, S. (2013) Men and things: Karl Polanyi, primitive accumulation, and their relevance to a radical green political economy. Environment and Planning A, 45, 15691587

Puar, J. (2007) Terrorist assemblages: Homonationalism in queer times. Durham: Duke University Press

Quiggin, J. (1993) Common property, equality, and development. World Dev. 217:11231138.

Radcliffe, S. A. (2012) Development for a postneoliberal era? Sumak kawsay, living well and the limits to decolonisation in Ecuador. Geoforum, 43(2), 240-249

Radcliffe, S.A. (2006) Development and Geography: gendered subjects in development processes and interventions. Progress in Human Geography 30 (4), 524-532.

Rankin, K. N. (2013) A critical Geography of poverty finance. Third World Quarterly, $34(4), 547-568$

RARE (2010) Deklarasi untuk Suarka Margasatwa Sungai Lamandau, http://www.rare.org/es/node/5876\#.VfKJtfmqqko, Accessed Online (18 March 2015)

RARE. (2011) Kisah Pemanfaat sekaligus Pendukung Lestarinya Sungai Dalam dan Sekitar SM Sungai Lamandau, http://www.rare.org/es/node/5885\#.VeTSZfaqqko, Accessed Online (15 February 2015) 
Resosudarmo, I.A.P., S. Atmadja, A.D. Ekaputri, D.Y. Intarini, Y. Indriatmoko, \& P. Astri (2013) Does Tenure Security Lead to REDD+ Project Effectiveness? Reflections from Five Emerging Sites in Indonesia. World Development, 55:68-83.

Ribot, J.C. (1998) Theorizing access: Forest profits along Senegal's charcoal commodity chain. Development and Change, 29:307-341.

Ribot, J.C. (2000) Forest Rebellion and Local Authority in Makacoulibantang, Eastern Senegal. 134-58 in People, Plants and Justice, edited by Charles Zerner. New York: Columbia University Press.

Ribot, J.C., \& N.L. Peluso (2003) A Theory of Access. Rural Sociology, 68(2):153-181.

Rigg, J., (1998) Rural-urban interactions, agriculture and wealth: a Southeast Asian perspective. Progress in Human Geography, 22, 497-522

Rigg, J. (2001) More than the soil: rural change in Southeast Asia. Prentice Hall, Harlow

Rigg, J. (2006) Land, farming, livelihoods, and poverty: Rethinking the links in the rural South. World Development, 34(1), 180-202

Rigg, J. (2007) An Everyday Geography of the Global South, Routledge: London

Rigg, J. (2012) Unplanned development: tracking change in South-East Asia. Zed Books.

Rigg, J., Salamanca, A. \& Parnwell, M. (2012). Joining the Dots of Agrarian Change in Asia: A 25 Year View from Thailand. World Development, 40(7), 1469-1481.

Robbins, P. \& Luginbuhl, A. (2007) The last enclosure: resisting privatization of wildlife in the western United States. In N. Heynen, McCarthy, J., Prudham, S., and Robbins, P. (Ed.), Neoliberal Environments: False Promises and Unnatural Consequences (25-37). London; New York: Routledge.

Robbins, P. (2004) Political Ecology: A Critical Introduction.Malden, MA: Blackwell Publishing

Robbins, P. (2012) Political Ecology. 2nd ed. Blackwell, Oxford.

Robinson, A. \& Tormey, S. (2005) A Ticklish Subject? Zizek and the Future of Left Radicalism. Thesis Eleven, 80(1), 94-107 
Robison, R. \& V.R. Hadiz. (2004) Reorganising power in Indonesia: the politics of oligarchy in an age of markets. New York: Routledge

Rocheleau, D. (2008) Political ecology in the key of policy: from chains of explanation to webs of relations. Geoforum 39 (2), 716-727.

Rocheleau, D., Thomas-Slayter, B., Wangari, E., (1996) Feminist Political Ecology. Global Issues and Local Experiences. Routledge, London.

Romero, P. S. (2015) 10 things you need to know about REDD+ safeguards - CIFOR, Forest News, http://blog.cifor.org/27281/10-things-you-need-to-know-about-reddsafeguards\#.VeaKbfaqqkp. Accessed Online (25 June 2015)

Rose, C. (1994) Property and persuasion - essays on the history, theory and rhetoric of ownership. Boulder: Westview Press.

Rose, G. (1997) Situating knowledges: positionality, reflexivities and other tactics. Progress in Human Geography, 21(3), 305-320.

Rose, N. \& Miller, P. (1992) Political power beyond the state: Problematics of government. British Journal of Sociology, 43(2), 173-205.

Rosling, H. (2014) Overpopulated - BBC Documentary. https://vimeo.com/113262271, Accessed Online (15 February 2014)

Routledge, P. (2003) Convergence space: process geographies of grassroots globalization networks. Transactions of the Institute of British Geographers, 28: 333349

Routledge, P. (2012) Sensuous solidarities: Emotion, politics and performance inthe clandestine insurgent rebel clown army. Antipode 44 (2): 428-52

Rowan, M. (2014) We need to talk about growth. (And we need to do the sums as well). http://persuademe.com.au/need-talk-growth-need-sums-well/. Accessed Online (15 June 2014)

Roy, A. (2004) Peace and the new corporate liberation theology - The 2004 Sydney Peace Prize Lecture. http://sydney.edu.au/news/84.html?newsstoryid=279. Accessed Online (14 December 2014) 
Rudel, T (2007) Changing agents of deforestation: from state-initiated to enterprisedriven processes, 1970-2000 Land Use Policy, 24 (1): 35-41

Rydin, Y. (1998) The enabling local state and urban development: resources, rhetoric and planning in East London. Urban Studies 35, 175-91

Said, E. W. (1978) Orientalism. Penguin, London

Sandor, R. L. (2012) Good Derivatives: A Story of Financial and Environmental Innovation, John Wiley \& Sons: New York

Sandor, R. L., Bettelheim, E. C., \& Swingland, I. R. (2002) An overview of a free-market approach to climate change and conservation. Philosophical Transactions. Series A, Mathematical, Physical, and Engineering Sciences, 360, 1607-1620

Sarat, A. \& Kearns, T. R. (1992) Introduction. In A. Sarat and T. R. Kearns eds. Law's Violence, 1-22. Ann Arbor: University of Michigan Press.

Saturi, S. (2014) Memperjuangan Kemerdekaan, Meraih Pengakuan Hak Masyarakat Adat. Accessed online 11 August 2014 from: http://www.mongabay.co.id/tag/diskiriminasi-masyarakat-adat/

Scheper-Hughes, N. \& Bourgois, P. (2004) Introduction: Making sense of violence. In N Scheper-Hughes and P Bourgois (eds) Violence in War and Peace (1-31). Malden: Blackwell

Scheper-Hughes, N. (1993) Death without weeping: The violence of everyday life in Brazil. Berkeley: University of California Press.

Schilt, K. \& Williams, C. L. (2014) Access Denied. Men and Masculinities, 11, 2, 219-226.

Schneider, L. \& Kollmuss, A. (2015) Perverse effects of carbon markets on HFC-23 and SF6 abatement projects in Russia. Nature Climate Change,

Schotle, J. A. (2000) Global civil society. In Woods, N. (eds) The political economy of globalization (Macmillan: London) 173-201

Scott, J. C. (1985) Weapons of the Weak: Everyday Forms of Peasant Resistance. Yale University Press, New Haven. 
Scott, J. C. (1990) Domination and the Arts of Resistance. New Haven, CT: Yale University Press

Scott, J. C. (1998) Seeing Like a State: How Certain Schemes to Improve the Human Condition Have Failed. Yale University Press

Scott, J. C. (2009) The Art of Not Being Governed. Yale University Press

Secor, A. (2001) Toward a feminist counter-geopolitics: gender, space and Islamist politics in Istanbul. Space \& Polity 5, 191-211

Sen, A. K. (1993) Capability and Well-Being, in Nussbaum and Sen (eds.), (Oxford: Clarendon Press).

Sharp, J. (2000) Remasculinising geopolitics? Comments on gearoidO’Tuathail's critical geopolitics. Political Geography 19, 361-364

Sharp, J. (2009) Geography and Gender: What Belongs to Feminist Geography? Emotion, Power and Change. Progress in Human Geography 33 (1): 74-80

Sharp, J., Routledge, P., Philo, C. \& Paddison, R. (2000), Entanglements of Power: Geographies of Domination/Resistance. Routledge: New York

Shaw, F. (2011) (Dis)locating Feminisms: Blog Activism as Crisis Response. Outskirts, 24: $1-10$

Sheppard, E., Porter, P., Faust, D. \& Nagar, R. (eds) (2009) A world of difference: encountering and contesting difference (second edition). London: Guilford.

Shipton, P., \& M. Goheen (1992) Understanding African Land-Holding: Power, Wealth, and Meaning, Africa, 62(3):307-25.

Shiraishi, T. (1997) Anti-Sinicism in Java's New Order, in Daniel Chirot and Anthony Reid, eds, Essential Outsiders: Chinese and Jews in the Modern Trans- formation of Southeast Asia and Central Europe, University of Washington Press, Seattle, WA, (190)

Sibley, D. (1995) Geographies of exclusion. London: Routledge

Sikor, T., \& C. Lund (2009) Access and Property: A question of power and authority. Development and Change, 40(1):1-22 
Sikor, T., \& Thanh, N. T. (2007) Exclusive versus inclusive devolution in forest management: Insights from forest land allocation in Vietnam's Central Highlands. Land Use Policy, 24(4), 644-653.

Silvey, R. (2004) Power, difference and mobility: feminist advances in migration studies. Progress in Human Geography, 28(4), 490-506

Silvey, R. (2010a) Development Geography: Politics and "the state" under crisis. Progress in Human Geography, 34(6), 828-834

Silvey, R. (2010b) Development Geography: Politics and "the state" under crisis. Progress in Human Geography, 34(6), 828-834

Simon, D. (2008) Political ecology and development: intersections, explorations and challenges arising from the work of Piers Blaikie. Geoforum, 39(2), 698 - 707.

Sjaastad, E., \& Cousins, B. (2008) Land Use Policy Formalisation of land rights in the South : An overview. Land Use Policy, 26, 1-9.

Skidmore, S., Santos, P., \& Leimona, B. (2014) Targeting REDD+: An Empirical Analysis of Carbon Sequestration in Indonesia. World Development, 64(2007), 781-790

Sloterdijk, P. (1988) Critique of cynical reason. Minneapolis, MN: University of Minnesota Press

Smith, F. (2001) Refiguring the Geopolitical Landscape: Nation, 'Transition' and Gendered Subjects in post-Cold War Germany, Space and Polity, 5, 213-235

Smith, L. (1999) Decolonizing Methodologies: Research and Indigenous People. Dunedin: University of Otago Press.

Smith, S. (2012) Intimacy-geopolitics: Religion, Marriage, and Reproductive Bodies in Leh, Ladakh, Annals of the Association of American Geographers, 102 (6): 1511-1528

Smith, S. (2012) Intimacy-geopolitics: Religion, Marriage, and Reproductive Bodies in Leh, Ladakh. Annals of the Association of American Geographers, 102(6), 1511-1528.

Sommerville, M. (2011) Land Tenure and REDD+: Risks to Property Rights and Opportunities for Economic Growth. USAID: Washington DC 
Spencer, M. D. (1999) Dispossessing the Wilderness: Indian Removal and the Making of the National Parks. New York: Oxford University Press

Springer, S. (2008) The nonillusory effects of neoliberalisation: Linking geographies of poverty, inequality, and violence. Geoforum, 39(4), 1520-1525

Springer, S. (2010) Neoliberal discursive formations: on the contours of subjectivation, good governance, and symbolic violence in posttransitional Cambodia. Environment and Planning D: Society and Space, 28(5), 931-950

Springer, S. (2011) Violence sits in places? Cultural practice, neoliberal rationalism, and virulent imaginative geographies, Political Geography, 30(2): 90-98

Springer, S. (2012) Neoliberalising violence: of the exceptional and the exemplary in coalescing moments, Area, 44(2): 136-143

Springer, S. (2014) Human Geography without hierarchy, Progress in Human Geography, 38(3): 402-419

Springer, S. (2016) Klepto-neoliberalism: authoritarianism and patronage in Cambodia, States of Discipline: Authoritarian Neoliberalims and the Crises of Capitalism Ed., Tansel, C. B. Lanham: Rowman \& Littlefield

Stacey, J. (1988) Can there be a feminist ethnography? Women's Studies International Forum, 11, 21-7

Staeheli, L. A. (2001) Of possibilities, probabilities and political Geography. Space and Polity 5: 177-89

Steffan W (2008) Surviving the Anthropocene. Paper presented in the Fenner School Seminar Series, Fenner School of Environment and Society, The Australian National University, Canberra, 16 October

Stern, N. (2006) Economics of Climate Change. Office of the Exchequer, London, UK Strassmann, D. (2008) Feminist Economic Methodologies. Feminist Economics, 14(2): 1 Strauss, S. \& Feiz, P. (2014) Discourse Analysis: Putting Our Worlds into Words. Routledge: London 
Streck, C. \& Terhalle, M. (2013) The changing geopolitics of climate change. Climate Policy, 13, (5): 533-537

Sullivan, S. (2009) Green capitalism. Radical Anthropology, 3, 18-27

Sullivan, S. (2010) Ecosystem Service Commodities - A New Imperial Ecology? Implications for Animist Immanent Ecologies, with Deleuze and Guattari. New Formations, 69(1), 111-128

Sullivan, S. (2012) Banking nature? The spectacular financialisation of environmental conservation. Antipode, 45 (1):198-217

Sultana, F. (2007) Reflexivity, positionality and participatory ethics: negotiating fieldwork dilemmas in international research. ACME, 6(3), 374-385.

Sundberg, J. (2004) Identities in the making: conservation, gender and race in the Maya Biosphere Reserve, Guatemala. Gender, Place and Culture 11 (1), 43-66

Sunderlin, W. D, Larson, A. M, Duchelle, A. E, Resosudarmo, I. .A. P., Huynh, T. B., Awono, A., \& Dokken, T. (2013) How are REDD+ proponents addressing tenure problems? World Develop- ment 55:37-52

Sunderlin, W. D., Larson, A. M. \& Cronkleton, P. (2009) Forest tenure rights and REDD+: From inertia to policy solutions. In Angelsen, A., Brockhaus, M., Kanninen, M., Sills, E., Sunderlin, W. D. and Wertz-Kanounnikoff, S. (eds) (2009) Realising REDD+: National strategy and policy options. CIFOR, Bogor, Indonesia

Sunstein, C.R. (1993) The Partial Constitution. Cambridge, MA: Harvard University Press.

Suryakusuma, J. (1991) State Ibuism: The Social Construction of Womanhood in the Indonesian New Order. New Asian Visions. 6 (2): 46-71

Swyngedouw, E. (2011) Depoliticized environments: the end of nature, climate change and the post-political condition. Royal Institute of Philosophy Supplement, 69, 253-274.

Szablowski, D. (2010) Operationalizing free, prior, and informed consent in the extractive industry sector? Examining the challenges of a negotiated model of justice. Canadian Journal of Development Studies 30, 111-130 
Tacconi, L. (2007) Illegal Logging: Law Enforcement, Livelihoods and the Timber Trade. London: Earthscan Publications.

Takacs, D. (2009) Forest Carbon: Law and Property Rights. Conservation International: Arlington

Taussig, M. T. (1998) Viscerality, faith, and skepticism: another theory of magic, in In Near Ruins Ed. N Dirks (University of Minnesota Press, Minneapolis, MN) 221-256

Tawney, R.G. (1978) Property and creative work. 133-51 in Property: Main-stream and Critical Positions, edited by C.B. MacPherson. Toronto: University of Toronto Press.

Taylor, J. (2011) The intimate insider: negotiating the ethics of friendship when doing insider research. Qualitative Research, 11(1), 3-22.

Thomas, S., Dargusch, P., Harrison, S. \& Herbohn, J., (2009) Why are there so few afforestation and reforestation Clean Development Mechanism projects? Land Use Policy, 27, 880-887

Thompson, E. P. (1963) The Making of the English Working Class. Random House Till, J. (2012) The broken middle: The space of the London riots. Cities, 34, 71-74 Titmuss, R. M. (1971) The Gift Relationship: From Human Blood to Social Policy. Pantheon Books, New York

Trudeau, D. (2006) Politics of belonging in the construction of landscapes: placemaking, boundary-drawing and exclusion. Cultural Geographies, 13(3), 421-443

Tsing, A. L. (2005) Friction: An Ethnography of Global Connection. Princeton, NJ: Princeton University Press

Tsing, A., (2000) Inside the economy of appearances. Public Culture, 12 (1), 115-144

Tubtim, N., \& Hirsch, P. (2004) Common Property as Enclosure: A Case Study of a Backswamp in Southern Laos. Society \& Natural Resources, 18(1), 41-60.

Turner, S. (2010) The silenced assistant: Reflections of invisible interpreters and research assistants. Asia Pacific Viewpoint, 51, 206-19 
Turtle, M. (2012) Is Orangutan Tourism Ethical? http://www.timetravelturtle.com/2012/10/seeing-orangutans-tanjung-putingborneo/. Accessed Online (2 September, 2014)

UNEP. (2015) About GEI - What is the 'Green Economy'? http://www.unep.org/greeneconomy/AboutGEI/WhatisGEI/tabid/29784/Default.aspx Accessed Online (21 June, 2015)

UNFCCC. (2015) 'Green Light' for Draft Agreement for Negotiation in October in Advance of Paris. http://newsroom.unfccc.int/unfccc-newsroom/governments-givegreen-light-for-draft-agreement-for-negotiation-in-october-in-advance-of-paris/.

Accessed Online (15 May, 2015)

US Congress (1998) S. Res.98 - 105th Congress (1997-1998): A resolution expressing the sense of the Senate regarding the conditions for the United States becoming a signatory to any international climate agreement, https://www.congress.gov/bill/105th-congress/senate-resolution/98, Accessed online (15 February 2015)

Valentine, G. (2005) Tell me about... using interviews as a research methodology. In R. Flowerdew \& D. Martin (Eds.), Methods in Human Geography: A Guide for Students Doing a Research Project (110-127). Harlow, England: Pearson Education.

van Klinken, G. (2008) Blood, timber, and the state in West Kalimantan, Indonesia. Asia Pacific Viewpoint, 49:35-47

Vanderbeck, R. M. \& Dunkley, C. M. (2004) Introduction: geographies of exclusion, inclusion and belonging in young lives. Children's Geographies, 2(2), 177-183

Vaneigem, R. (1967 [1994]) The Revolution of Everyday Life, 2nd rev. edn, trans. David Nicholson-Smith. London: Rebel Press

Vhugen, D. \& J. Miner. (2011) REDD+ and carbon rights: lessons from the field. Property Rights and Resource Governance Project (PRRGP). USAID, Tetra Tech ARD, Burlington, VT, USA 
Vidal, J. (2008) The great green land grab. The Guardian UK, 13 February. http://www.guardian.co.uk/environment/2008/feb/13/conservation. Accessed Online (31 October 2013).

Visseren-Hamakers, I. J., C. McDermott, M.J. Vijge, \& B. Cashore (2012) Trade-offs, cobenefits and safeguards: Current debates on the breadth of REDD+. Current Opinion in Environmental Sustainability, 4(6):1-8.

Vivero Pol, J. L. (2015) Transitioning Towards a Food Commons Regime: ReCommoning Food to Crowd-Feed the World, http://papers.ssrn.com/sol3/papers.cfm?abstract_id=2548928. Accessed Online (15 February 2015)

Vollan, B. (2008) Socio-ecological explanations for crowding-out effects from economic field experiments in southern Africa. Ecological Economics, 67(4), 560-573

Von Benda-Beckmann, F., Von Benda-Beckmann, K. \& Wiber, M. G. (2006) The properties of property. In: Von Benda-Beckmann, F., Von Benda-Beckmann, K., Wiber, M.F. (Eds.), Changing Properties of Property. Berghahn Books, New York, 1-39

Walker, P. A. (2005) Political ecology: where is the ecology? Progress in Human Geography, 29(1), 73-82.

Walker, P. A. (2007) Political ecology: where is the politics? Progress in Human Geography, 31(3): 363-369

Waring, M. (1988) If women counted: A new feminist economics. NewYork: HarperCollins

Warr, P. (2005) 'Boom, Bust and Beyond', in P. Warr (ed.) Thailand Beyond the Crisis, 365. New York: Routledge Curzon

Watts, M. (1983) Silent violence: Food famine \& peasantry in Northern Nigeria. Berkeley, CA, USA: University of California Press.

Watts, M. (2000) Political ecology. In: A companion to economic Geography (eds. Sheppard, E. and T. Barnes). Pp. 257-274. London: Blackwell. 
Watts, M. (2008) Curse of the black gold: 50 years of oil in the Niger Delta. Brooklyn, NY: Powerhouse Books

Wax, R. H. (1979) Gender and Age in Fieldwork and Fieldwork Education: No Good Thing is Done by Any Man Alone. Social Problems, 26 (5): 509-522

Webber, M. (2012) The Political Economy of the Three Gorges Project. Geographical Research, 50(2), 154-165

Wemaere, M., C. Streck, \& Chagas, T (2009) Legal ownership and nature of Kyoto units and EU allowances. In: Freestone, D. and Streck, C. (eds) Legal aspects of carbon trading: Kyoto, Copenhagen and beyond. Oxford University Press, Oxford, UK.

White, B. (1989) Problems in the empirical analysis of agrarian differentiation, in B. Hart, A. Turton and B. White (eds) Agrarian Transformations: Local Processes and the State in Southeast Asia. University of California Press.

Whitington, J. (2012) The prey of uncertainty: Climate change as opportunity. Ephemera, 12 (1/2): 113-137

Whitmore, A. (2006) The emperors new clothes: sustainable mining? Journal of Cleaner Production 14, 309-314.

Whitten, A. J. (1987) Indonesia's transmigration programme and its role in the loss of tropical rainforest. Conservation Biology 1 (3): 239-46.

Wood, E. M. (2002) The Origins of Capitalism: A Longer View. London: Verso

Woodyer, T. \& H. Geoghegan (2012) (Re)enchanting Geography? The nature of being critical and the character of critique in human Geography, Progress in Human Geography 37(2): 195-214

World Bank. (2002) Building Institutions for Markets. World Development Report 2002. World Bank and Oxford University Press, Washington, DC.

World Bank. (2005) The World Bank Operations Manual. The World Bank, New York, $(1-553)$ 
World Bank. (2006) Sustaining Economic Growth, Rural ivelihoods, and Environmental Benefits: Strategic Options for Forest Assistance in Indonesia. Jakarta, Indonesia. World Bank: Washington

World Bank. (2013) Indonesia: A Nationwide Community Programme (PNPM) Peduli: Caring for the Invisible. http://www.worldbank.org/. Accessed Online (19 June 2014)

Wright, M.W. (2008) Gender and Geography: knowledge and activism across the intimately global. Progress in Human Geography 33 (3), 379-386

Yayorin. (2009) Laporan Participatory Rural Appraisal - Inisiatif Masyarakat Kelompok dalam Persiapan HKm dan REDD+. Yayorin: Pangkalanbuun

Yocum, H. (2013) The Price of Trees: Producing Carbon Commodities and Conservation in Malawi's Protected Areas (Un-published PhD Thesis) Michigan State University

Zhang, L., Mol, A. P. J. \& Sonnenfeld, D. (2007) The interpretation of ecological modernization in China. Environmental Politics, 16 (4): 659-668

Žižek, S. (1998 [2008]) The Sublime Object of Ideology. Verso Books: London

Žižek, S. (2006) A Pervert's Guide to Cinema (Film). ICA Films: London

Žižek, S. (2008) Violence: Six Sideways Reflections. New York: Picador.

Žižek, S. (2011) Living in the End Times. Verso Books: New Yorks

Žižek, S. (2014) Trouble in Paradise. Allen Lane: London 